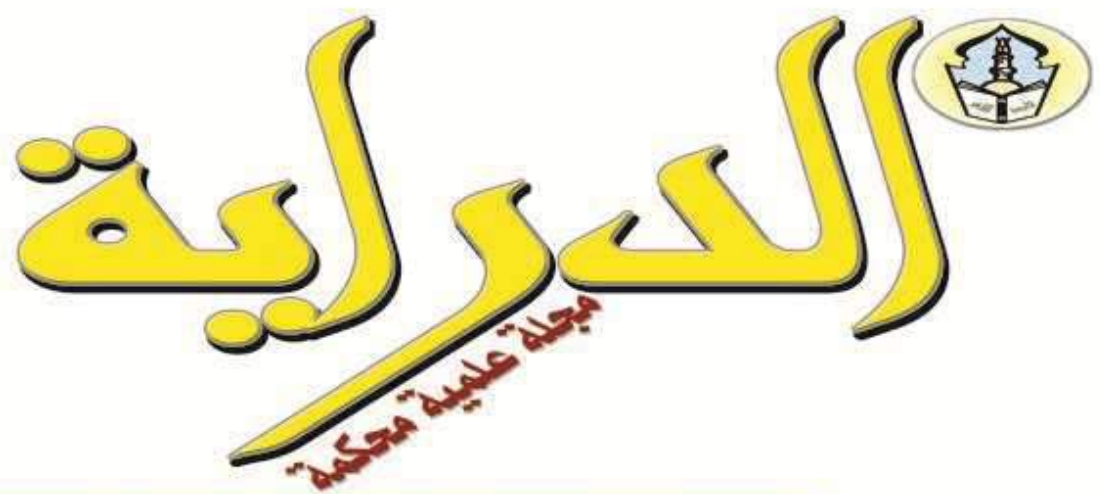

تصدرها كلية الدراسات الإسلامية والعربية بنين بلدسوق

$$
\begin{aligned}
& \text { Jyaxi } \\
& \text { دراسة تطبيقية على علل ابن أبي حاتم (ت V Y F ) } \\
& \text { رحمه الله تعالى }
\end{aligned}
$$

$$
\begin{aligned}
& \text { دكتور } \\
& \text { سامح عبد الله عبد القوي متولي } \\
& \text { مدرس الحليث وعلومه بكلية أصول الدين بـالقاهرة }
\end{aligned}
$$




\begin{tabular}{|c|c|}
\hline العدد الغامس عشر الجزي الأول لعام 10rم & مجلــة اللدرايــــة \\
\hline
\end{tabular}




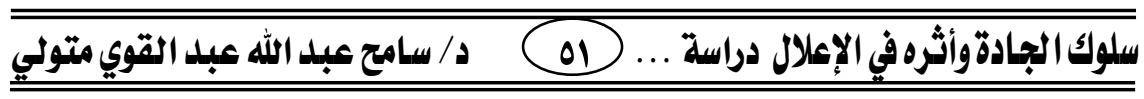 \\ المقدمة}

الحمد لله الذي بحمده يستفتح كل كناب، وبذكره يصدر كل خطاب، الحمد لله

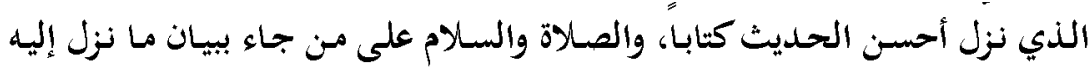

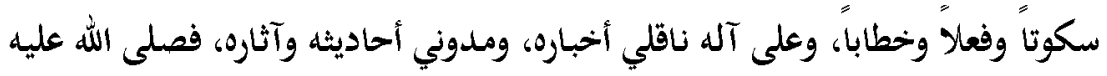

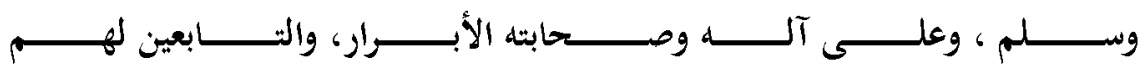

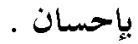

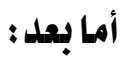

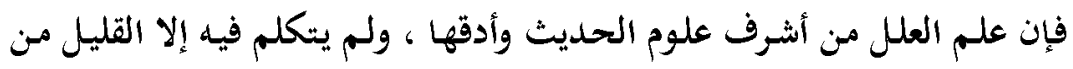

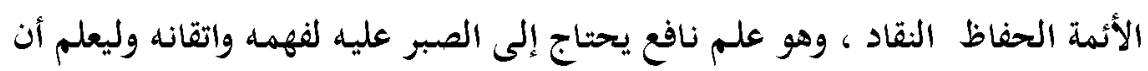

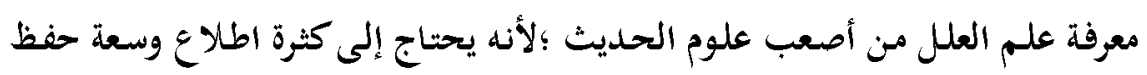

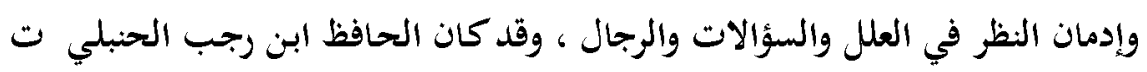

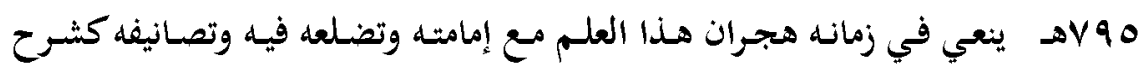

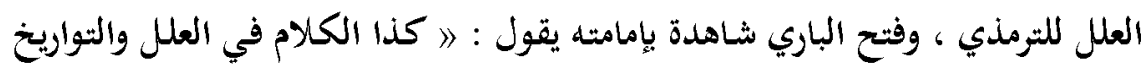

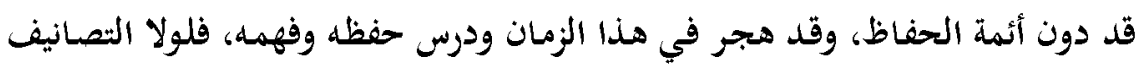

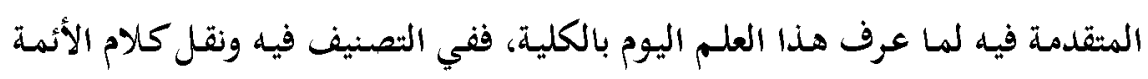

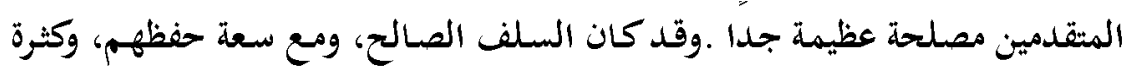

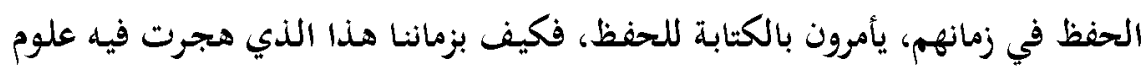

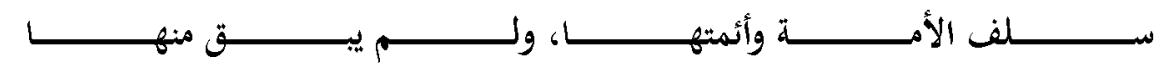
إلا ما كان مدونً ا في الكتب، لتشاغل أهل هذا الزمان بمدان بمدراسه الآراء وحفظها؟؟ أهـ.

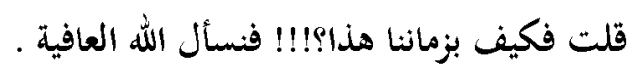

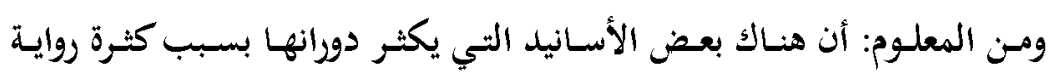

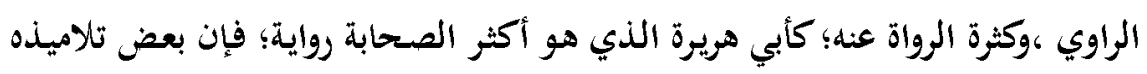

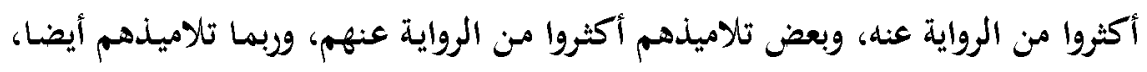

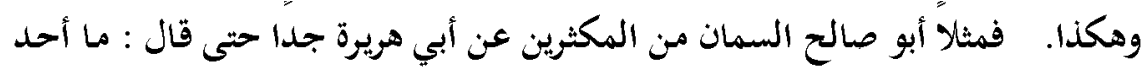




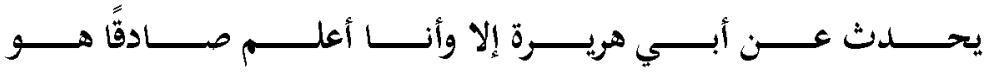

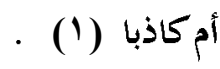

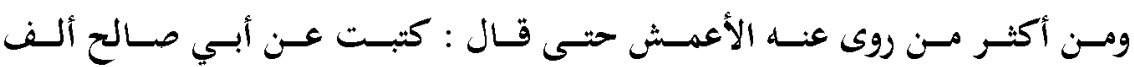

حديث. (r)

فهكذا يكون الأعمش عن أبي صالح عن أبي هريرة جادة تسبق إليها الألسنة.

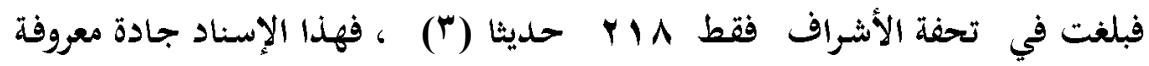

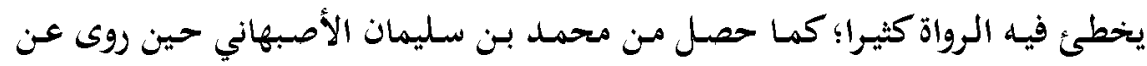

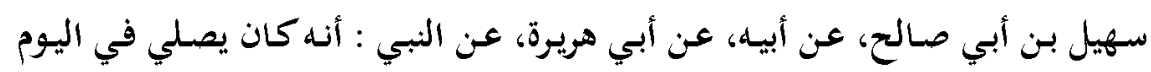
والليلة ثنتي عشرة ركعة.

فقد سأل عبد الرحمن بن أبي حاتم - وسياتي في المسألة الثانية من الدراسة النطبيقية

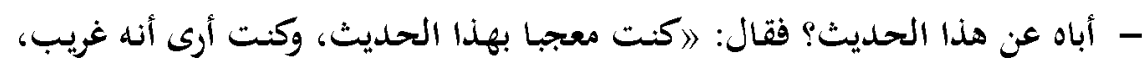

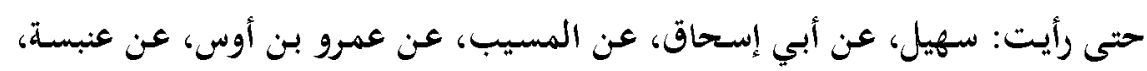

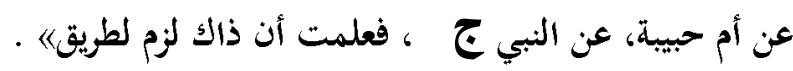

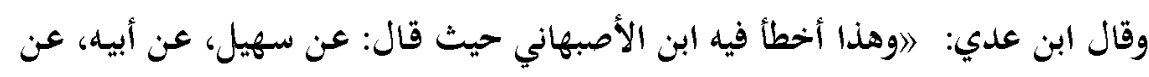
أبي هريرة، وكان هذا الطريق أسهل عليهه ؛ يعني أسهل عليه في الحفظ والرواية.

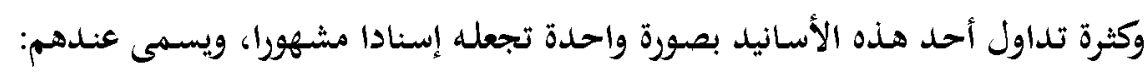

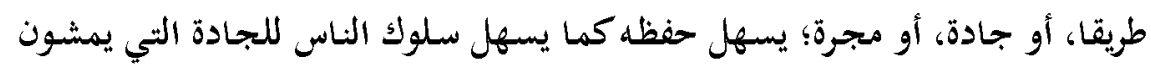

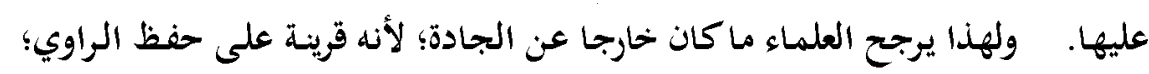

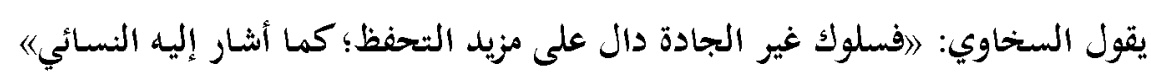

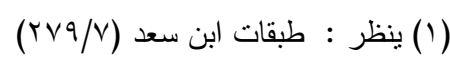

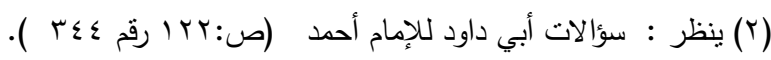

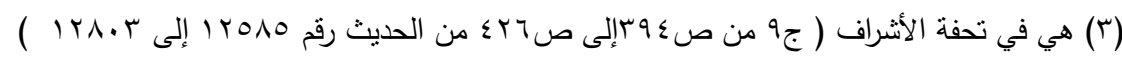

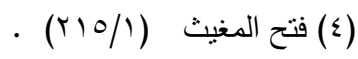




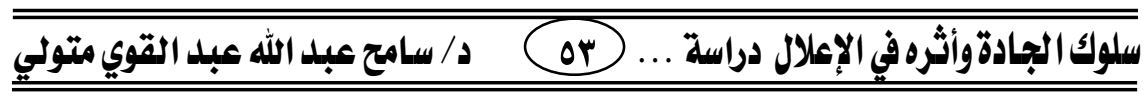

وقال الحافظ ابن حجر: 》الذي يجري على طريقة أهل الحديث: أن رواية عبد العزيز

شاذة؛ لأنه سلك الجادة، ومن عدل عنها دل على مزيد حفظهه (1) (1) .

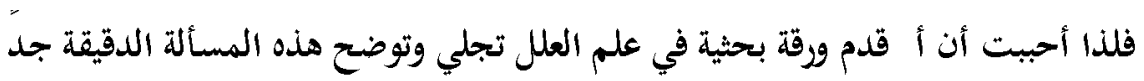

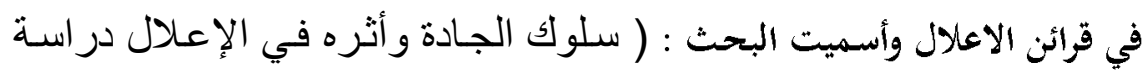

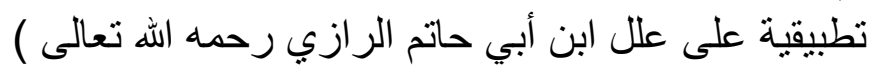

وأما خطة البحث فهي تشتمل على مقدمة ، ومبحثين ، وخاتمة:

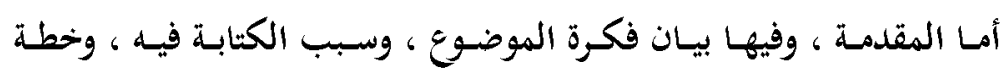
البحث.

وأما المبحثان فهما: المبحـث الأول: التعريـف بسـلوك الجـادة ، وتعـابير المحسدثين عـن سـلوك الجـادة، وأقسامها في الإسناد والمتن.

المبحث الثاني : دراسة المسائل التطبيقية ، وتخريجها ودراسة وجوه الخلاف والِ ، والنظر والثرجيح ، والحكم على الحديث من وجهه الراجح ، والتعليق على المسألة.

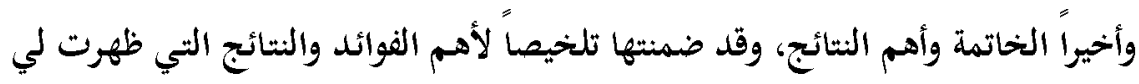
من خلال معايثة البحث، ودراسته. 


\section{مجلــة اللدرايــة}

\section{البجةث الأول :}

\section{التعريف بسلكك الجادة ، وتعابير المعديز عز سلوك الجادة، وأقساهها في الإسناد والمتّز}

التعريف بسلوك الجادة : تعبير استعمله جهابذة النقد عند إعلالهم لبعض الأحاديـث ، حينمـا تكـون هنـاك سلسـلة إســاد معروفـة مشهـورة، فتسـبق

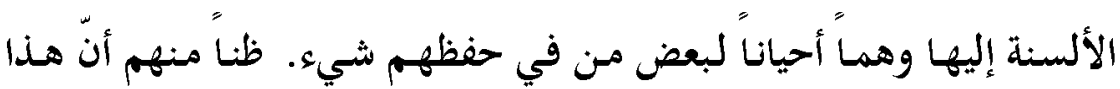
الحـديث جـاء على الجـادة في هـذا الإســاد، أمـا الحفـاظ المتقنـون فيبقـون على الصـواب، وينـدر أن يقعوا في مثل ذلك ويقول الكول الأئمسة النقاد إن الأول

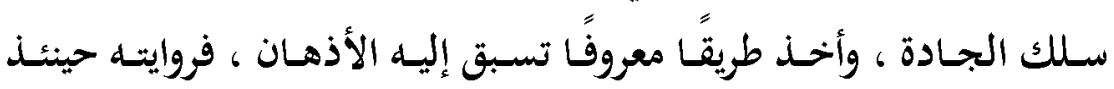

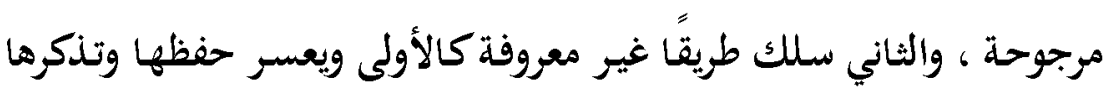
فروايته راجحة .

ومن المعروف حرص أهل الحديث على الإكثار من الشيوخ ، وجرت العادة

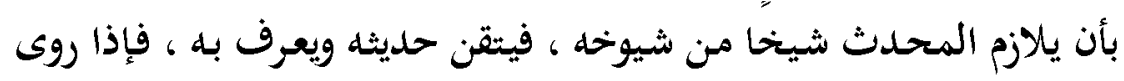

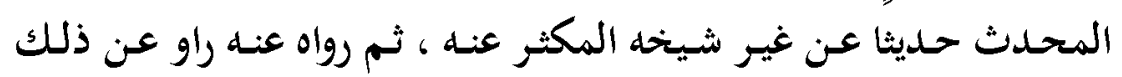
الشيخ كان في ذلك قرينة على خطأ مـذا الراوي ؛لأنه سـلك الجـادة في الإسـناد التي تسـبق إليها الألسـنة ، ولم يـنفطن لعدول شيخهل عن الإسـناد المشهور ، ويدل هذا دلالة واضحة إن الراوي الذي خحالف الجادة قد حفظ وضسبط ولأنه لا يلجـأ إلى غيـر الصسورة المعتـادة في الإسـناد والمشهـور إلا

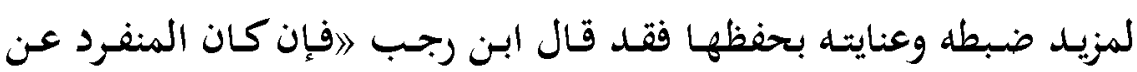
الحفاظ، مع سوء حفظه قد سلك الطريق المشهور، والحفاظ يخالفونه، فإنه 


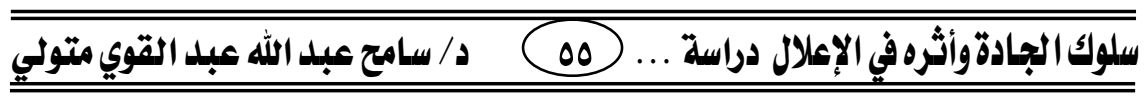

لا يكاد يرتاب في وهمده وخطئه، لأن الطريق المشهور تسبق إليه الألسنة

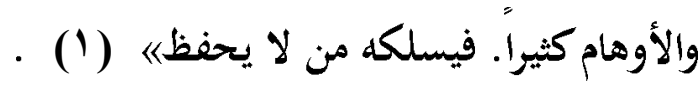

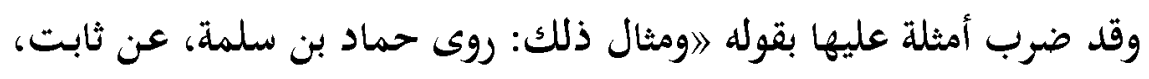

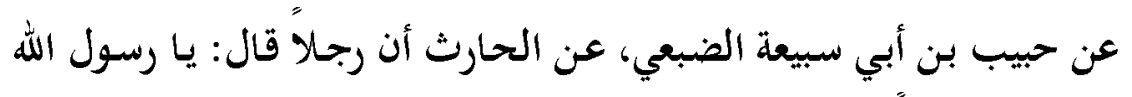

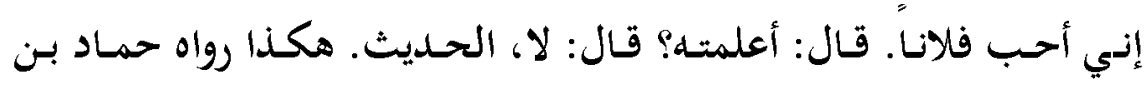
سلمة، وهو أحفظ أصحاب ثابت، وأثبتهم في

حديثه، كما سبق. وخالفه من لم يكن في حفظه بذاك من الشيوخ الرواة عن

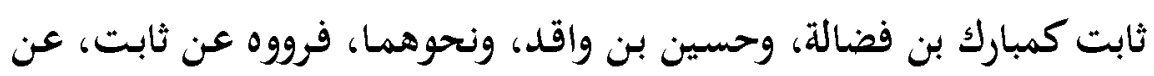
أنس عن النبي . صلى الله عليه وسلم ..

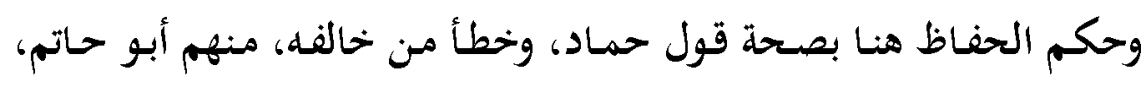
والنسائي ، والدارقطني. قال أبو حاتم: مبارك لزم الطريق، يعني أن رواية ثابـت عن أنس سلسلة

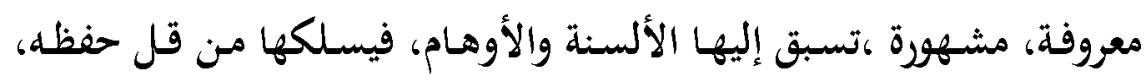

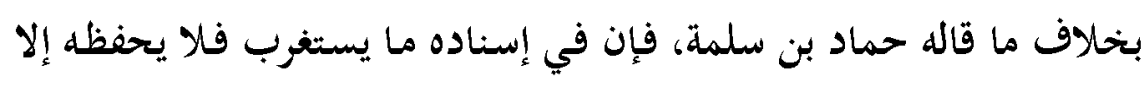
حافظ.

وأبو حاتم كثيراً ما يعلل الأحاديث بمثل هذا وكذلك غيره من الأئمةه. (r) (ج) 


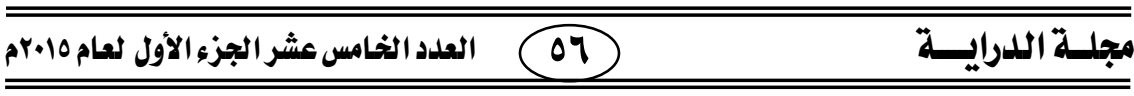

وقال أيضا شارحا قول الإمام أحمد : أهل المدينة إذاكان الحديث غلطا،

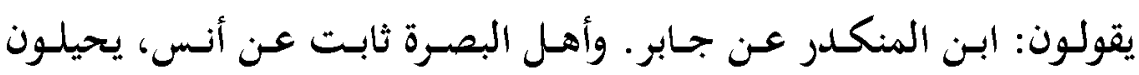
علوما.

ومراد أحمد بهذا كثرة من يروي عن ابن المنكدر من ضعفاء أهـل المدينة، وكثرة من يروي عن ثابت من ضعفاء أهل البصرة، وسيء الحفظ والمجهولين

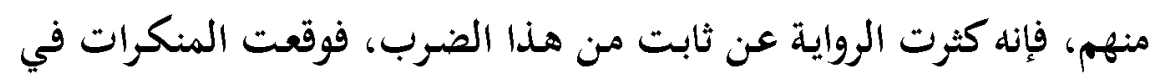

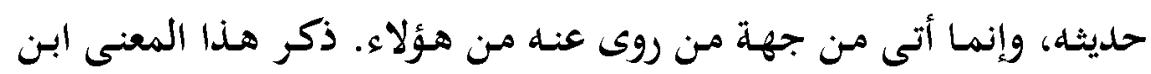

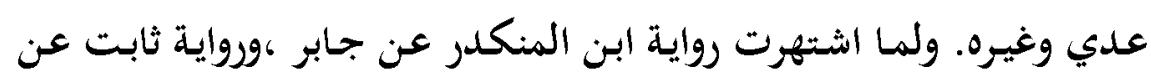
أنس صار كل ضعيف وسيء الحفظ إذا روى حديثا عن ابن المنكدر يجعله

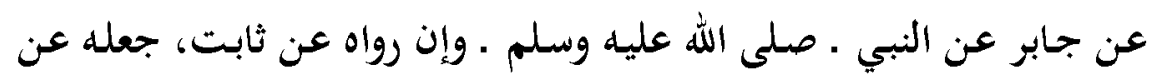

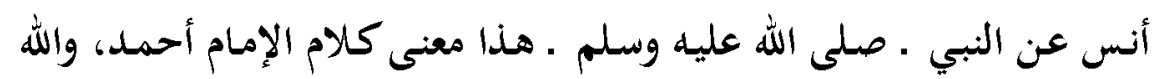

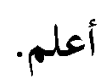
قلـت : وهـذه الدراسـة تبين مـا تقـدم مـن كلام الإمـام ابن رجـب الحنبلي ـ رحمه الله تعالى ـ وقد علل بها غير واحدد من الأئمة قبل أبو حاتم الرازي منهم عبد الرحمن بن مهدي ، وسفيان بن عيينة ، والإمام الشـافعي ، والإمام

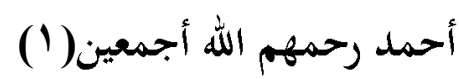
فمنها قول الحميديٌ : 》 قيل لسفيان - أي ابن عيينة - : إن عبد الرحمن

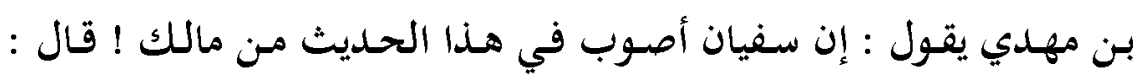

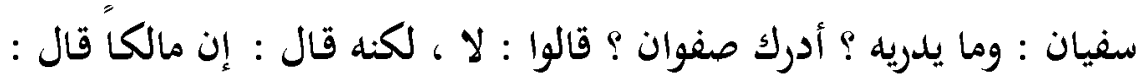

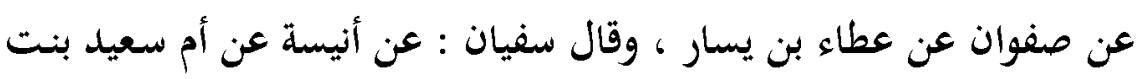




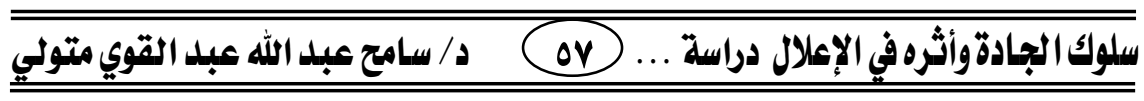

مرة عن أبيها. فمن أين جاء بهذا الإسناد ؟ فقال سفيان : ما أحسن ما قال ! لو قال لنا صفوان عن عطاء بن يسار كان أهون علينا من أن نجيء بهذاء لإنا ن.

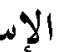

الشّديد 《) (1)

وقد استعمل غير واحد من الأئمة بعد أبي حاتم الرازي منهم البزار ، وابن

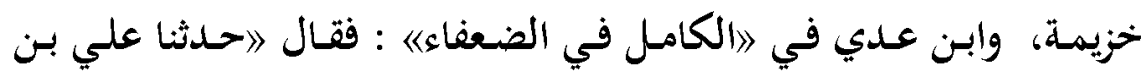

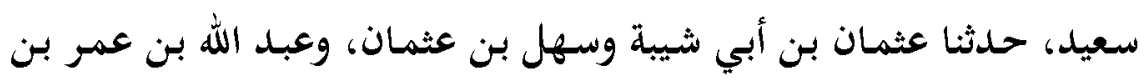

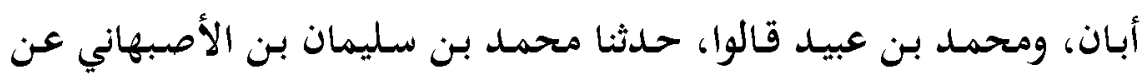

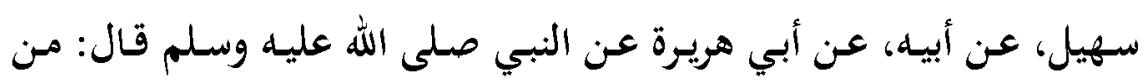

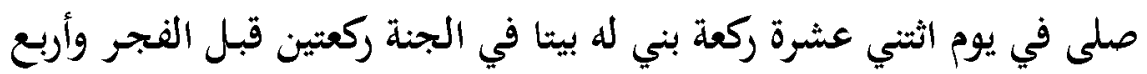

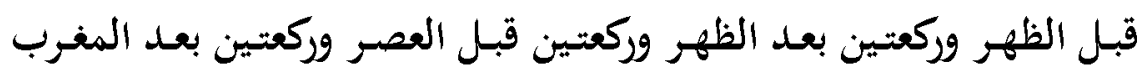
وركعتين بعد العشاء. قال الشيخ: وهذا أخطأ فيه بن الأصبهاني حيث قال عن سهيل ،عن أبيه،

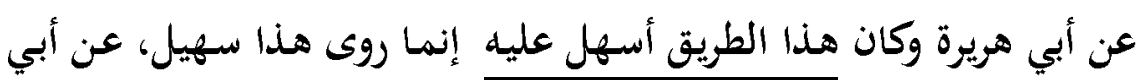

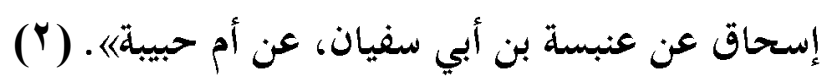

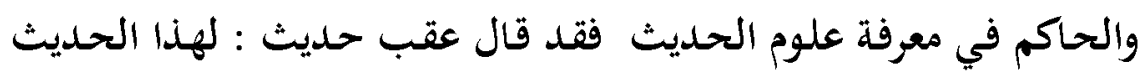
علة صحيحة والمنذر بن عبد الله أخذ طريق المجرة فيه(")

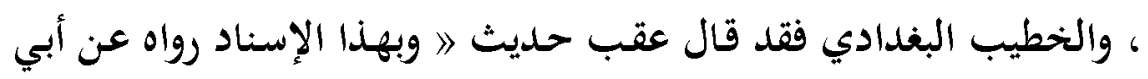

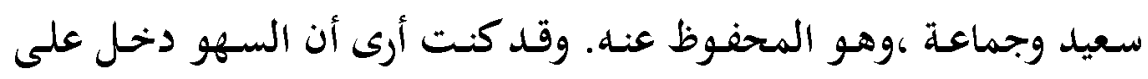

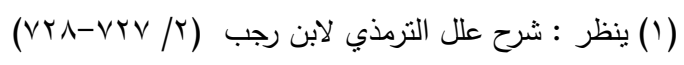

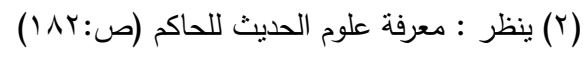

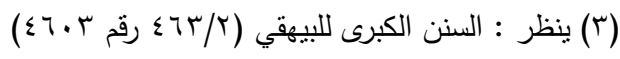




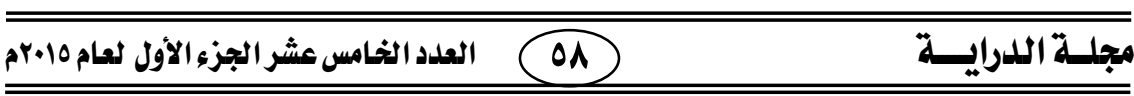

الطرازي في روايته إياه، وأقول لعله سمعله من أبي سعيد، عن بشر بن معاذ

بالإسناد المذكور فتوهمه في نسخة خراش لاشتهار العدوي بها، حتى رأيت

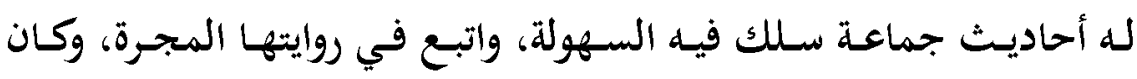

يحدث كثيرا من حفظه) (1)

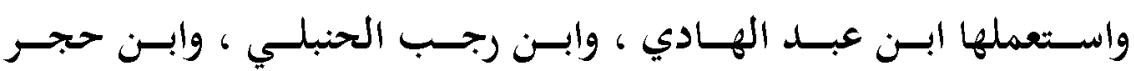

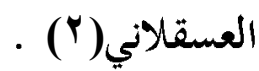

(Y) ينظر : هذه القرينة وأثرها في الاعلاد من تطبيقات الحافظ ابن حجر في الفتح في الرسالة الماتعة بعنوان " قرائن الترجيح في المحفوظ والثاذ وفي زيادة التقة عند الحافظ بن حجر في فتح الباريه للباحث

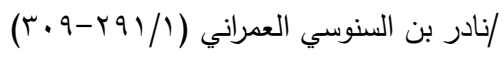




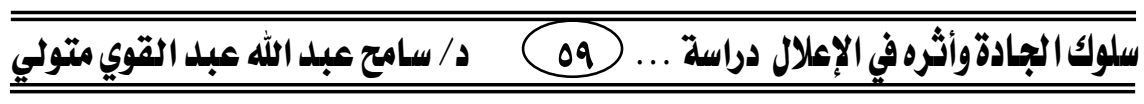

تعابير المحدثين عن سلوك الجادة :

عبارات النقاد في استخدامها متعددة فيقولون بالإضافة إلى التعبير المعروف

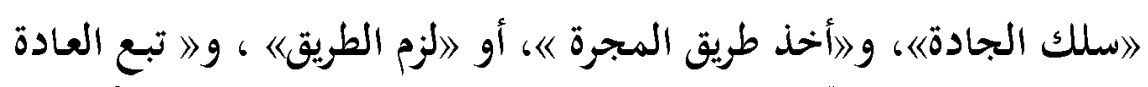

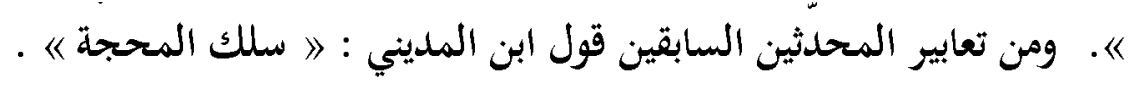

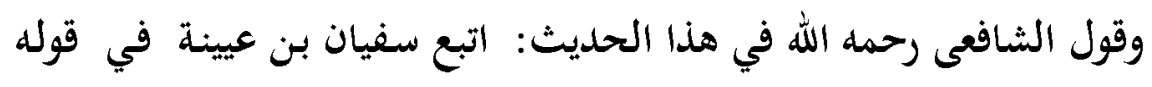

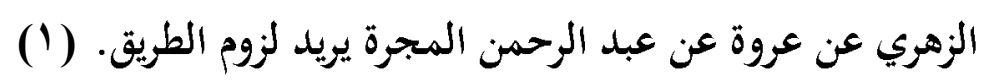

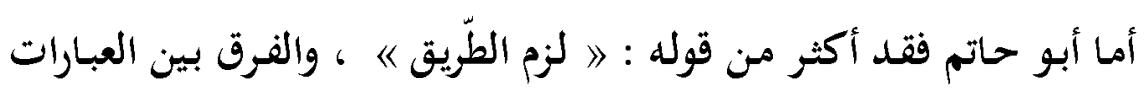
يسير.

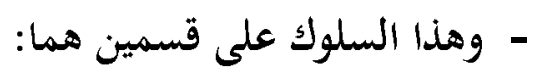
(1) - (1) سلوك للجـادة في الإسـناد : وهو الغالب والأكثر . فإنها إذا

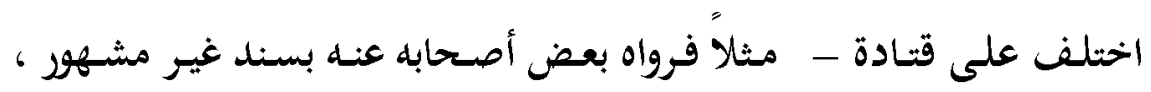

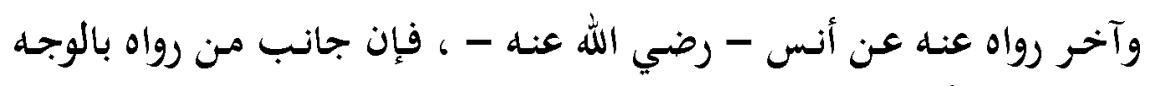

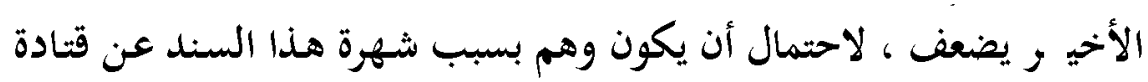

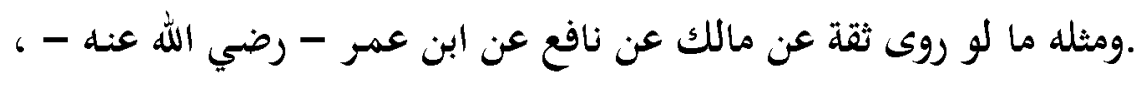
وغيره يرويه بسند آخر أقل شهرة. (r)

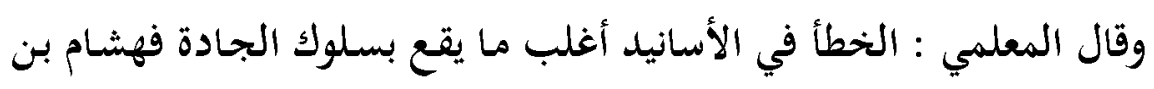

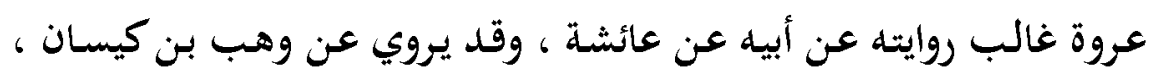

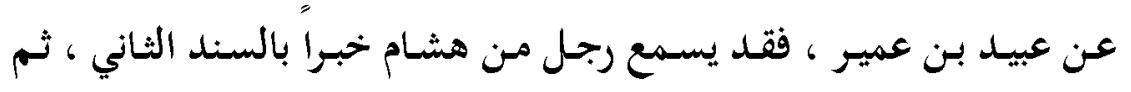

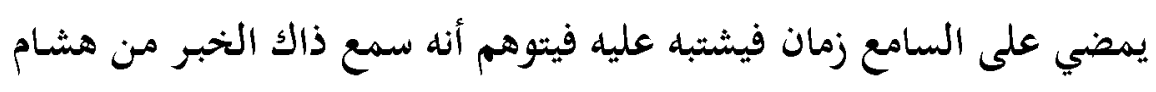

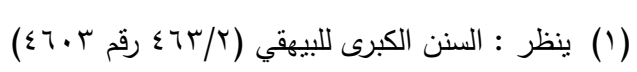

$$
\begin{aligned}
& \text { (r) ينظر : قرائن الثزبيح لعادل الزرقي ص ص : } 9 \text { وما بعدها بتصرف. }
\end{aligned}
$$




\section{مجلـة" اللدرايــة}

بالسند الأول على ما هو الغالب المألوف ، ولذلك تجد أئمة الحديث إذا

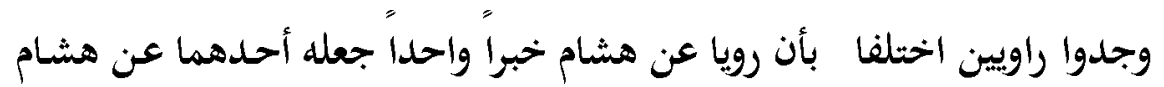
، عن وهب عن عبيد ، وجعله الآخر عن هشام ، عن أبيه ، عن عائشة ،

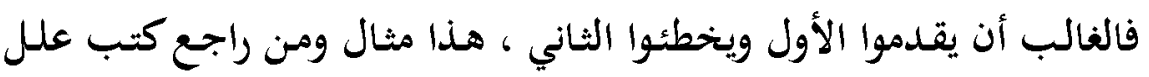
الحديث وجد من هذا ما لا يحصى. (1)

(Y) سلوك للجادة في المنن : وهو قليل، فبعض الأحاديث تشتهر بلفظ معين يرويه به غالب الرواة ، وينفرد راو برويته بلفظ آخر فإذا روى عنه بعض تلاميذه هذا الحديث باللفظ المشهور دل على أنه لم يضبطه وأنه

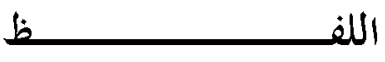
علـ

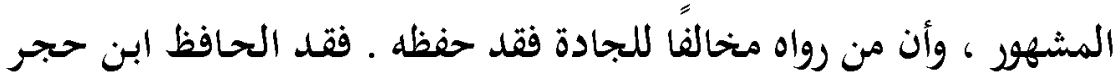

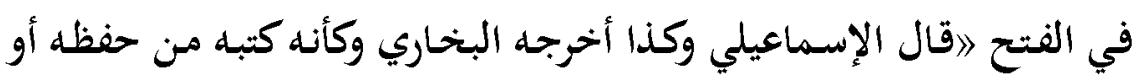

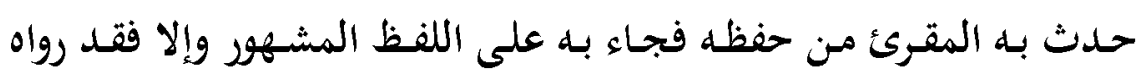

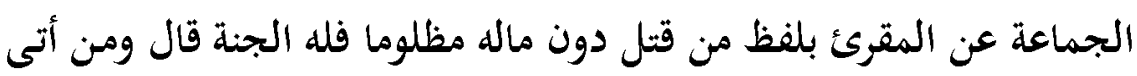

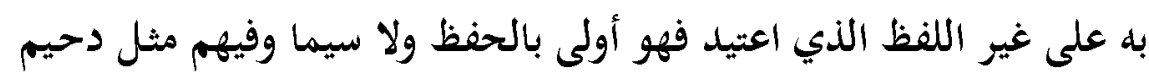

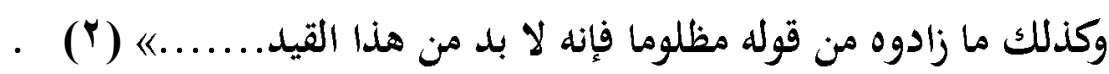

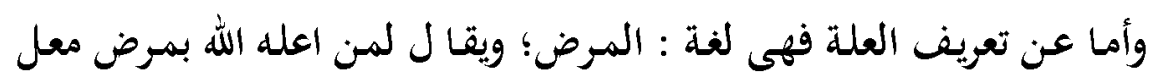
وعليل. 


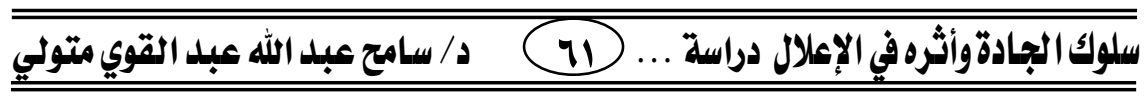

والحـديث المعلل : هـو خبـر ظاهره السـلامة اطلع فيـه بعـد النغتيش على

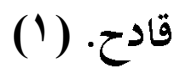

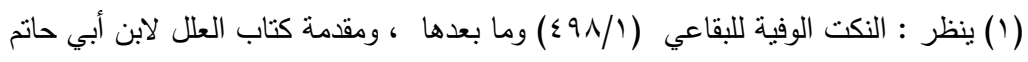

$$
\begin{aligned}
& \text { (107- (10V/l) }
\end{aligned}
$$




$$
\text { التمده ونسبه وموطنه بابن أبي حاتم(1) }
$$

هو الإمام ابن الإمام، حافظ الري وابن حافظها: عبد الرحمن بن أبي حاتم

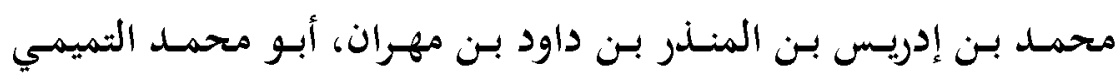
الحنظلي، وقيل: بـل الحنظلي فقط؛ وهي نسبة إلى درب حنظلة بـالري، كان يسكنه والده.

نشأته وطلبه للعلم وصبره فيه: كان من عادة سلف الأمة تربية أبنائهم على تقديم القرآن والعناية بـه قبل العلوم الأخرى ،وهذا ما فعله أبو حاتم الرازي بابنه عبد الرحمن؛ كما أخبر هو عن نفسه:

قال أبو الحسن علي بن إبراهيم الرازي الخطيب - في ترجمة عملها لابن

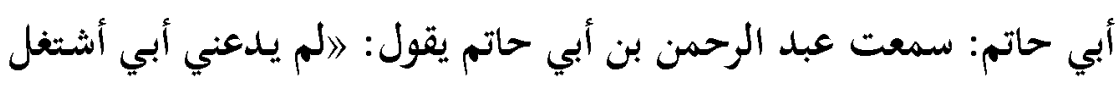

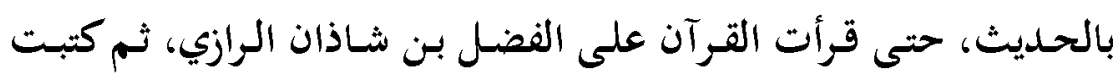

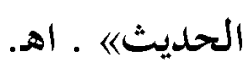

وقد أثنى عليه العلمـاء فقال ابن أبي يعلى: \أبو محمد الإمـام، ابن الإمام، الحافظ《)

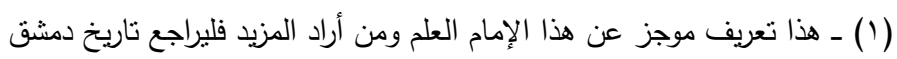

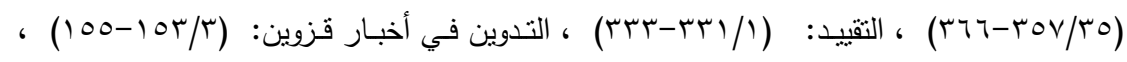

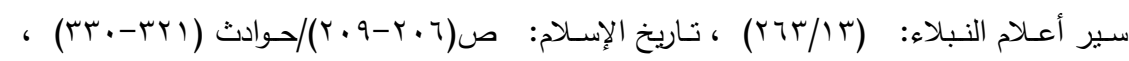

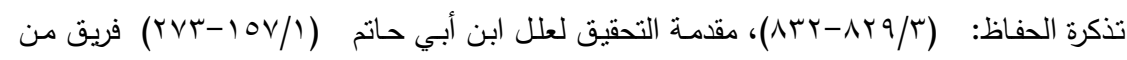

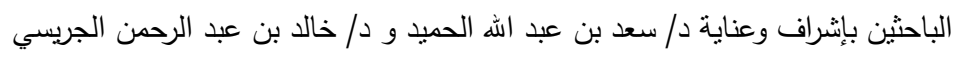




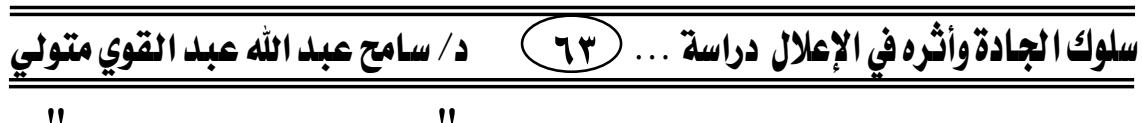

وقـال ابـن عســكر: أاحسد الحفــاظ، صـنف كتـاب الجـرح والتعـديل ، فأكثر فائدته، رحل في طلب الحديث؛ . وقال القزويني: 》امن كبار الدنيا علما وورعاش《) . وقال ابن نقطة : الإمام ابن الإمام《) . $"$

وقال ياقوت : 》أحد الحفاظ، صنف الجرح والتعديل ، فأكثر فائدته) . وهذه عبارة الحافظ ابن عساكر السابقة، فيبدو أنه أخذها عنه. وقال الذهبي : اوكان بحر الا تكدره الدلاء《) . وقال الحافظ ابن كثير : 》الحافظ الكبير، ابن الحافظ الكبير《) . وقـد تمكن عبـد الرحمن بـن أبي حـاتم - مـن خـلال ملازمتـه لأبيـه ولأبي زرعة، وكثرة رحلاته العلمية وسعة اطلاعه ورواياته - من جمع مادة علمية دفعتل إلى كثرة التصنيف الذي أشار إليه يحيى بن منده بقوله : \اصنف

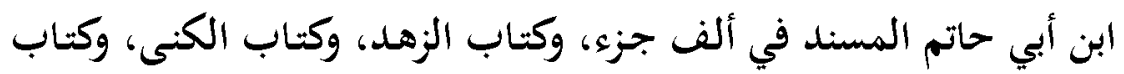
الفوائد الكبير، وفوائد أهل الري، وكتاب تقدمة الجرح والتعديله ، وأشار

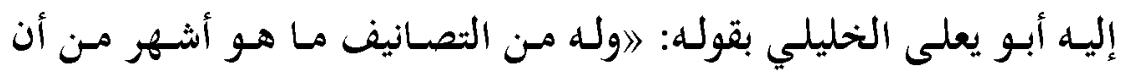
يوصف؛ في الفقه، والتواريخ، واختلاوف الصحابة والتابعين وعلماء الأمصار

توفي ابن أبي حاتم رحمه الله تعالى في المحرم سنة سبع وعشرين وثلاث مئة، بالري، وهو في عشر التسعين، أي: وله بضع وثمانون سنة. 


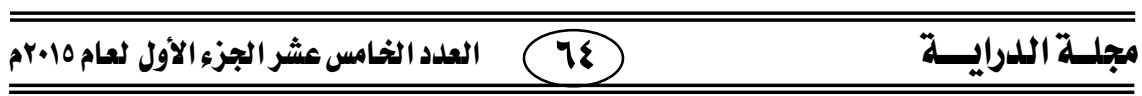

\section{المبحث الثاذي}

\section{النماذج التطبيقية}

\section{المسألة الأولى}

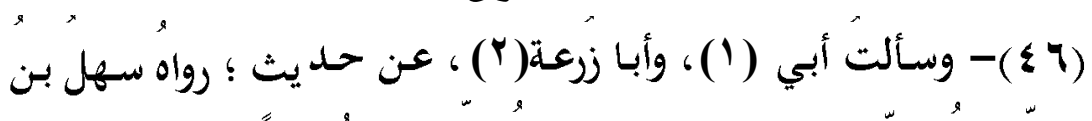

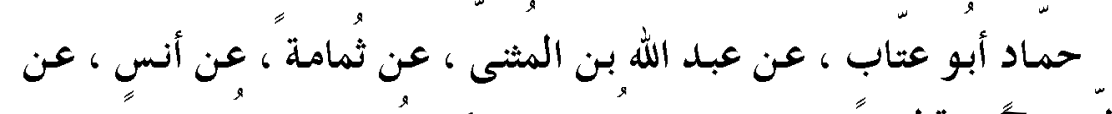

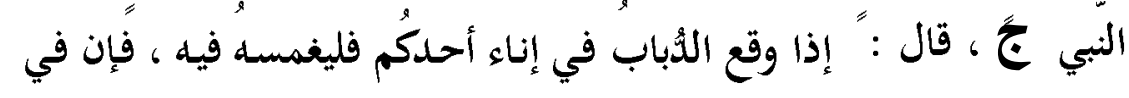
أحد جناحيه داء ، وفي الآخر شفاء.

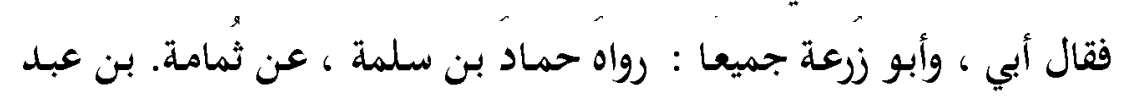
الله ، عن أبي هريرة.

(1) - هو محمد بن إدريس بن المنذر بن داود بن مهران، الحنظلي، الغطفاني، الرازي.

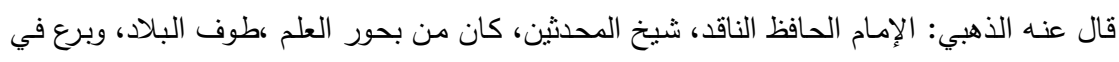

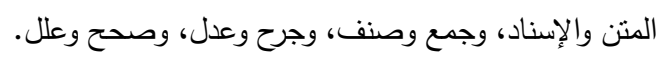

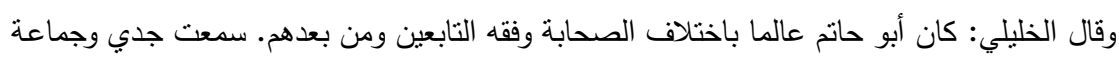

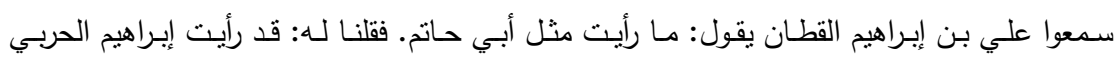

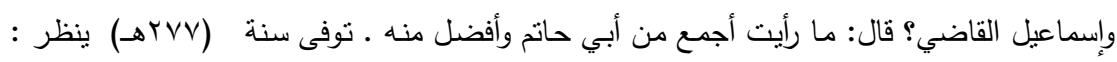

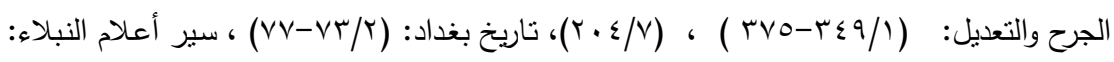

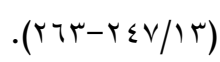

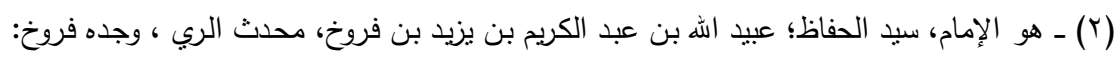

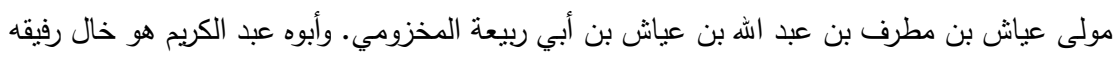

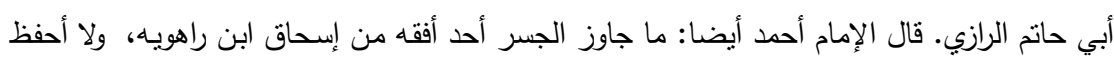

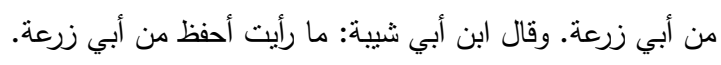

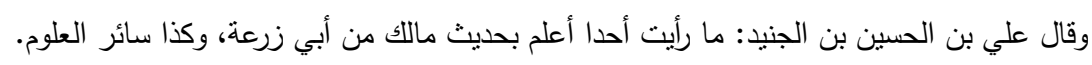

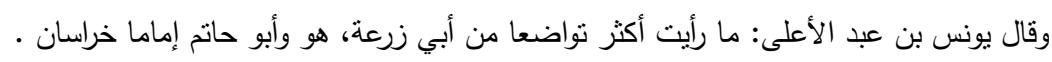

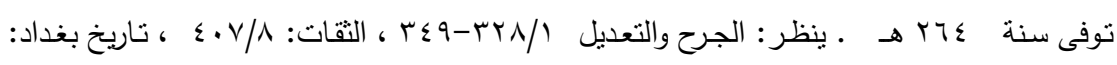

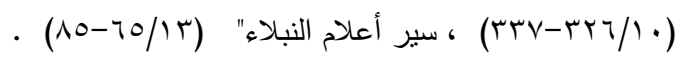




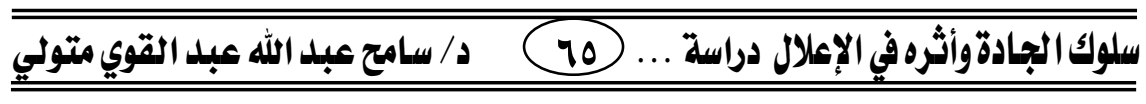 \\ قال أبو زرعة : وهذا الصحيح.}

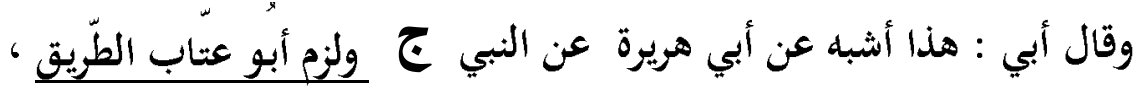
فقال : عن عبد الله ، عن ثُمامة ، عن أنسٍ.

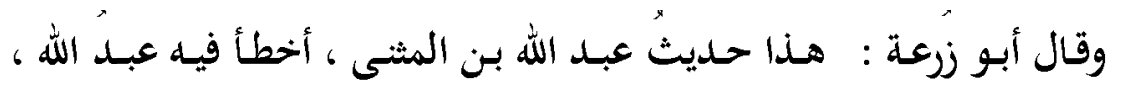

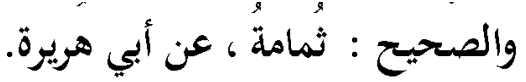

$$
\begin{aligned}
& \text { ذ التّخريج: }
\end{aligned}
$$

هذا الحديث يروى عن ثمامة واختلف عنه على وجهين :

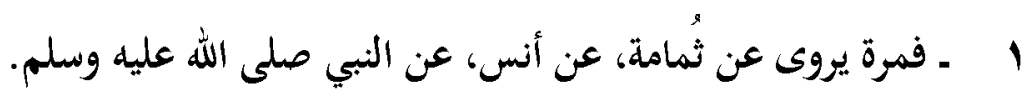
ᄉ ومرة يروى عن ثُمامة، عن أبي هريرة، عن النبي صلى الله عليه وسلم.

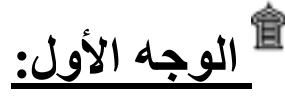

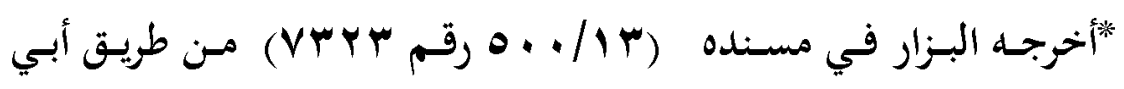
عتاب بن سهل بن حماد ،بله

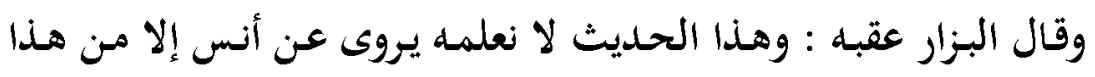
الوجه بهذا الإسناد.

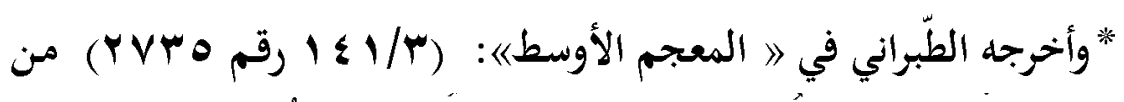

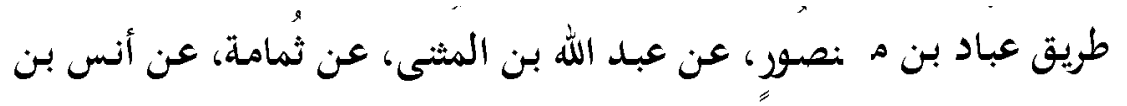
مالك ، بله بنحوه. الوجه الثاني: يروى عن ثُمامة، عن أبي هريرة، عن النبي صلى الله عليه وسلم

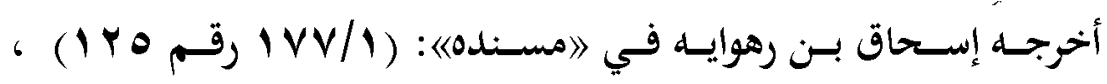

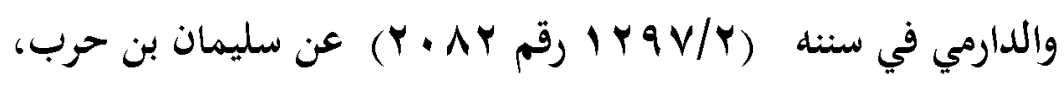




\section{العدد الخامس عشر الجزي الأول لعام 10 مبم}

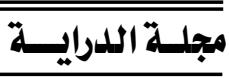

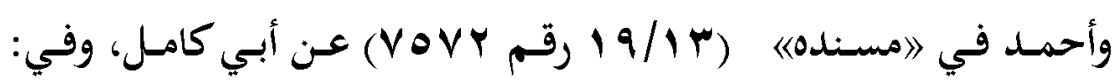

$$
\text { بq०/1 }
$$

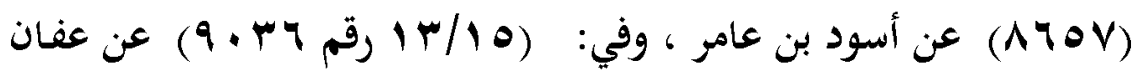

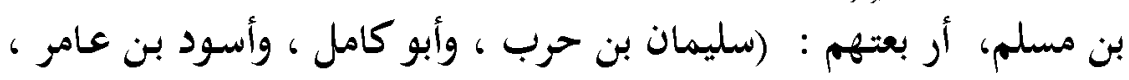

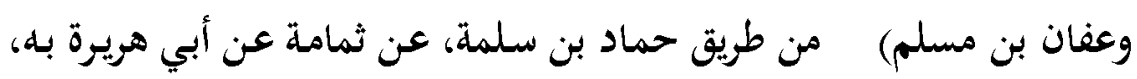
بنحوه.

ذ دراسة إسناد الوجه الأول عند البزار في مسنده : عن زياد بن يحيى، ومحمد بن معمر، قالا: حدّثنا أبو عتاب بن سهل بن حماد، حدّثنا عبد اللّه بن المثنى، عن ثُمامة، عن أنس....

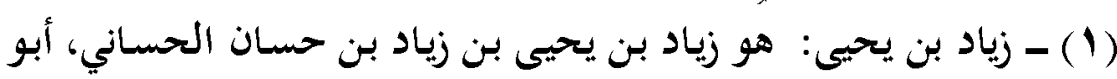

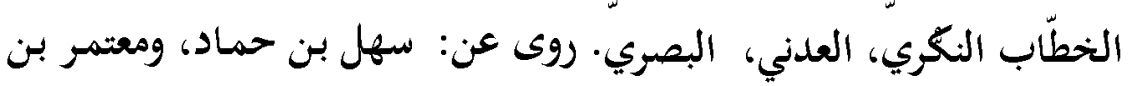
سليمان، وحاتم بن وردان، وغيرهم. وروى عنه: الجماعة، والبزار كما في هذا الإسناد، وغيرهم.

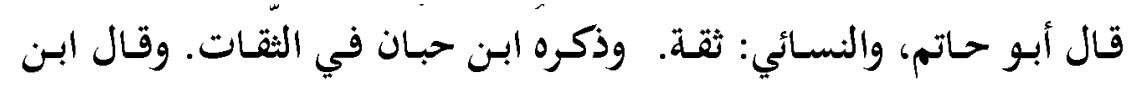

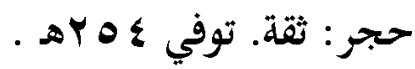
خُلاصةُ حاله أنه: ثقة.

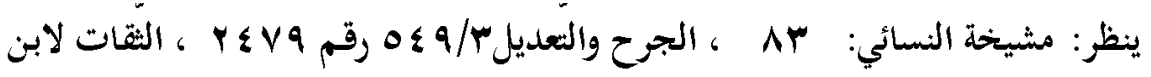

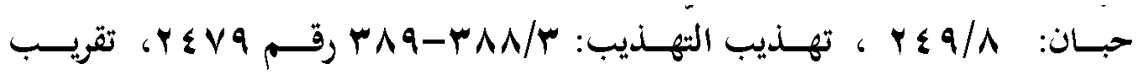

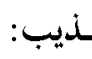
الته

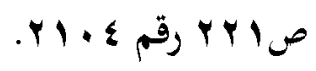

(Y) سهل بن حماد: سهل بن حماد العنقزي، أبو عتاب الدّلال، البصري 


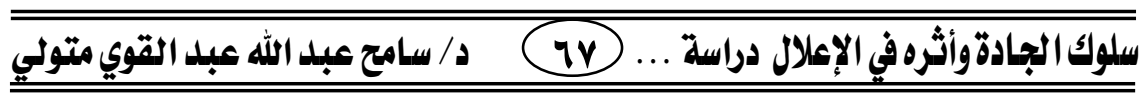

روى عن: إبراهيم بن عطاء بن ميمونة، وشعبة بن الحجاج، ، وهمام بن

$$
\text { يحيى، وغيرهم. }
$$

وروى عنه: علي بن المديني، وزياد بن يحيى الحساني، وحجاج بن الشاعر،

$$
\text { وغيرهم. }
$$

قال العجلي، وأبو بكر البزار: ثقة.

وقال أحمد بن حنبل، وعُمان الداّمي: لا بأس بله.

وقال عثمان الداّرمي عن ابن معين: لا أعرفه.

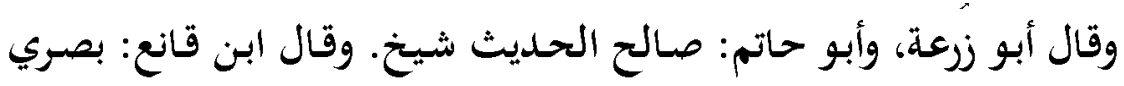
صالح.

وذكرهُ ابن حبان في الثّقات. وقال الذّهبي، وابن حجر: صدُوق وهو كما

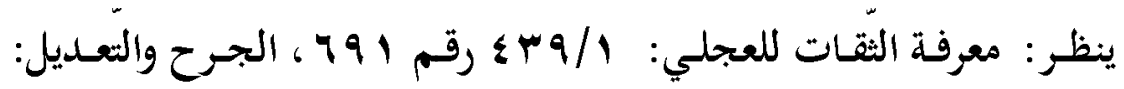

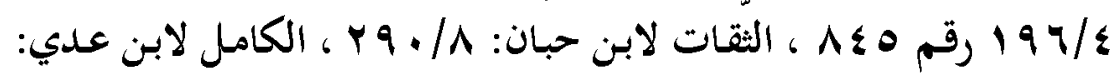

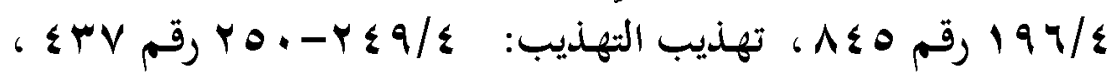

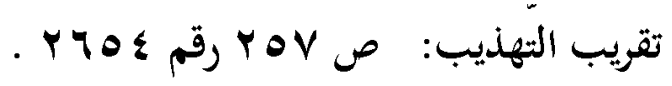

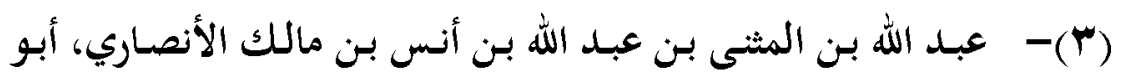

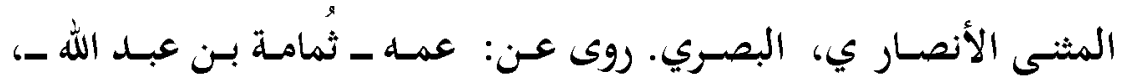

$$
\text { والحسن البصري، وثابت البناني، وغيرهم. }
$$

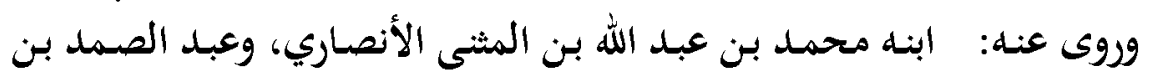

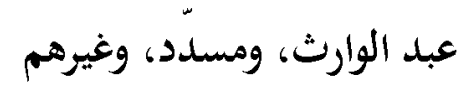




\section{مجحلـة اللدرايــةهة}

قال العجلي: ثقة. وقال الترمذي محمد بن عبد الله الأنصاري: ثقة، وأبوه ثقة. وقال ابن معين: صالح، ومرة قال : ليس بشيء. وقال أبو زرعة، وأبو حاتم: صالح، وزاد أبو حاتم: شيخ.

وقال النسائي: ليس بالقوي. وذكره ابن حبان في الثقات، وقال : ربما أخطأ. وقال الآجري عن أبي داود: لا أخرج حديثه، وقال في موضع آخر حدثنا

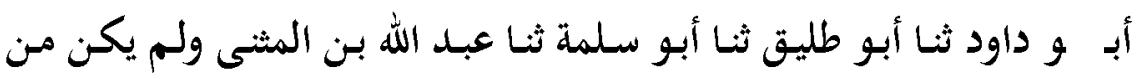
القريتين عظيم، وكان ضعيفاً منكر الحديث.

وقال السـاجي: فيسه ضـف لم يكـن مـن أهـل الحـديث روى منـاكير . وقال العقيلي: لا يتابع على أكثر حديثه. واختلفـت أقوال الدّارقُطني فقـال : ثقـة حجـة، وقـال مـرة: ثقـة، وقتال مـرة: ضعيف. وقال ابن حجر: صدوق كثير الغلط، وقال في الهدي: لم أر البخاري احتج إلا في روايته عن عمده ثمامـة فعنده عنه أحاديث وأخرج له من روايته عن ثابت عن أنس حديثا توبع فيه عنده وهو في فضائل القرآن وأخرج لهن له أيضا في اللباس عن مسلم بن إبراهيم عنه عن عبد الله بن دينار عن ابن عمر في النهي عن القزع بمتابعة نافع وغيره عن ابن عمر.

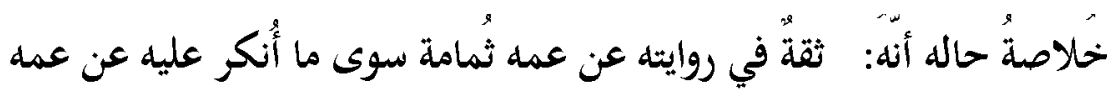

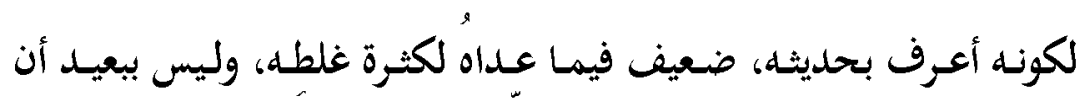

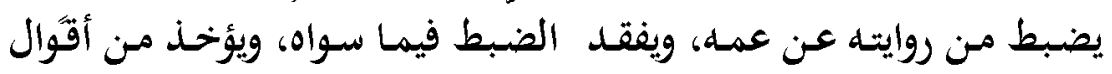




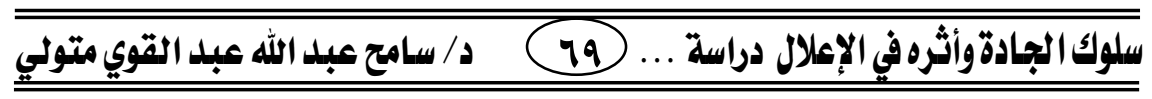

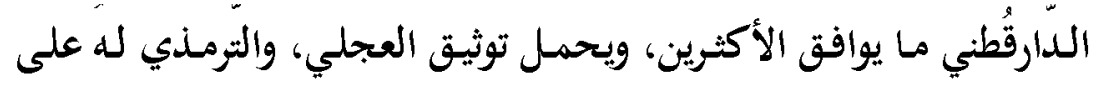

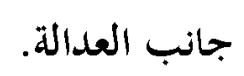

قلت: وفي هذا الحديث يروي عن عمده فانتفت علة الضعف، ولكن هذا الحديث مما أنكر عليه.

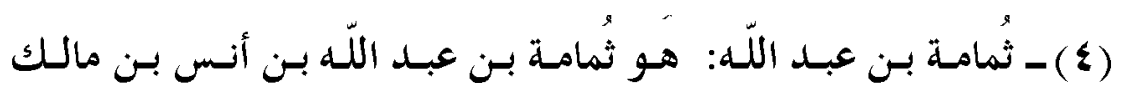
الأنصاري، البصري قاضيها. روى عن: جده أنس، والبراء بن عازب، وغيرهما.

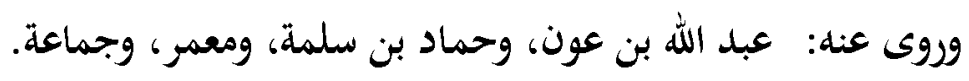

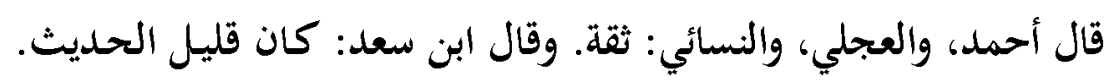

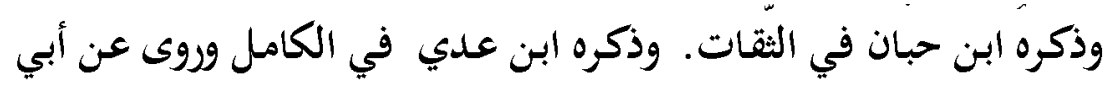

$$
\text { يعلى أن ابن معين أشار إلى تضعيفه }
$$

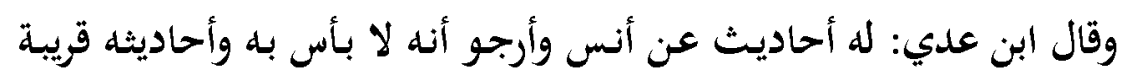

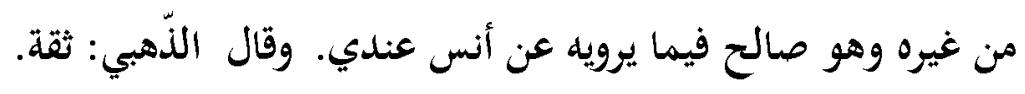

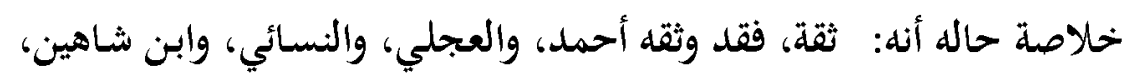

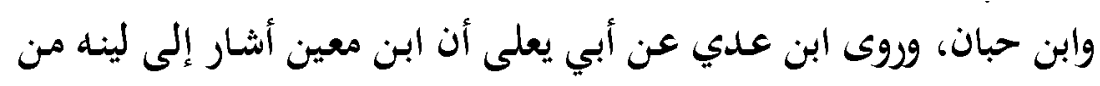

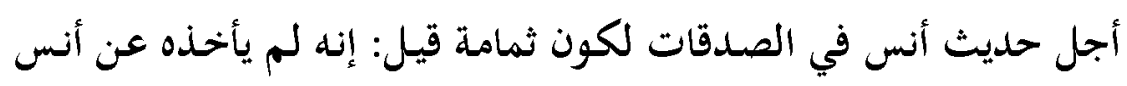

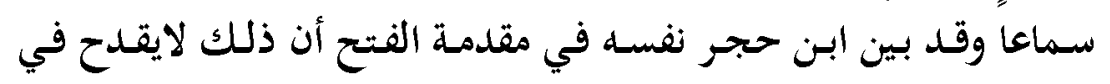

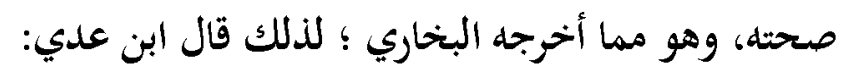
هو صالح فيما يرويه عن أنس عندي.

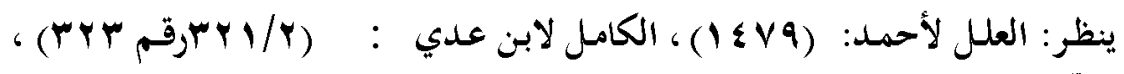

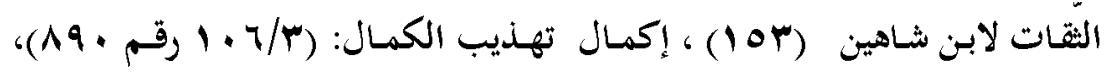




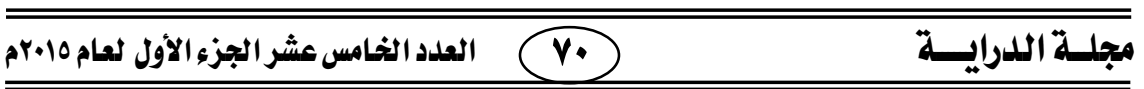

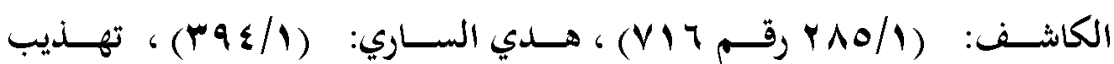

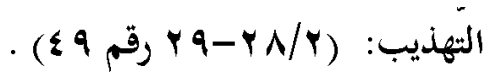

هـ أنس بن مالك رضى الله عنه : صحابي جليل خادم النبي صلى الله عليه

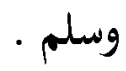

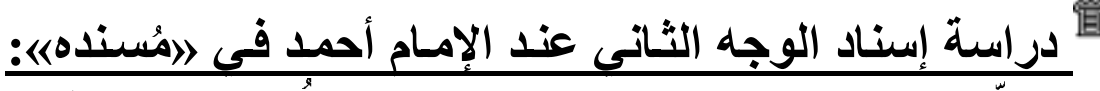

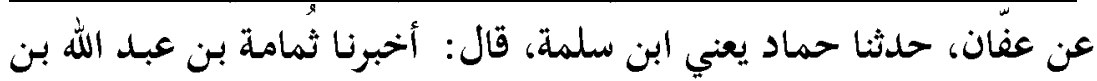

$$
\text { أنس، عن أبي هريرة رضى الله عنه ........ }
$$

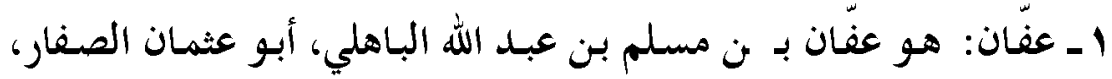

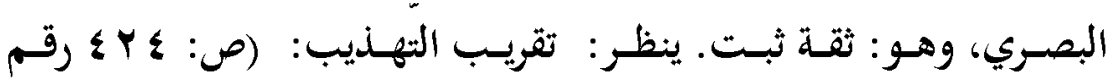

Y ـ حماد بن سلمة: ثقه عابـد أثبـت النـاس في ثابـت وتغير حفظه بأخرة، لكن ما كان من روايته عن ثابت أو خاله حميد الطويل، أو من رواية عفان بن مسلم عنه فهى صحيحة.

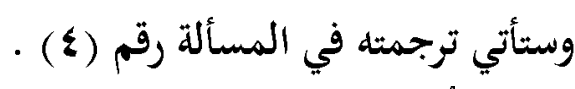

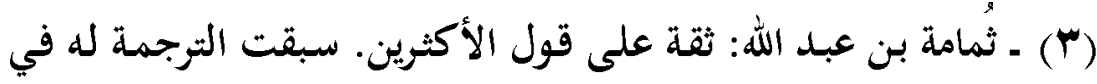
دراسة إسناد البزار الأول .

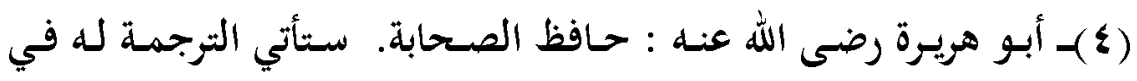
المسألة الثانية.

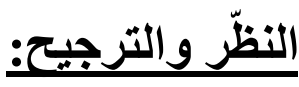

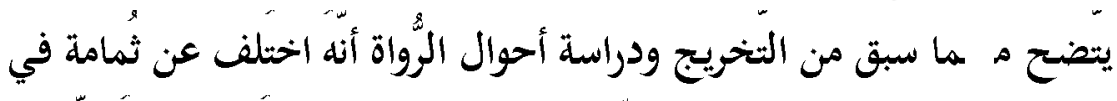

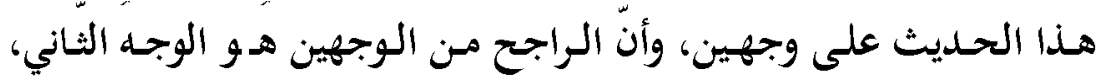
وذلك لما يلي: 


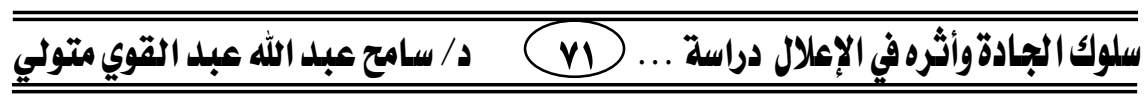

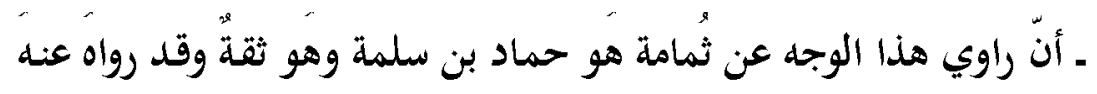

عفّان بن مسلم وروايته عنه صحيحة.

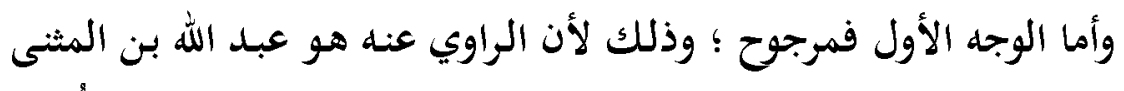

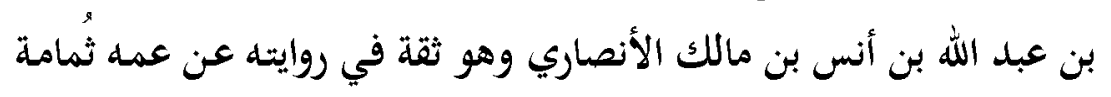

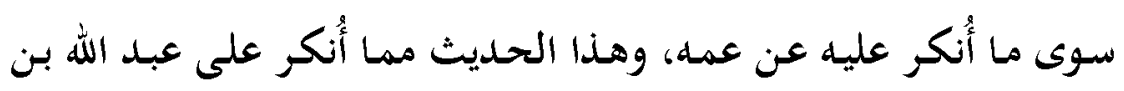

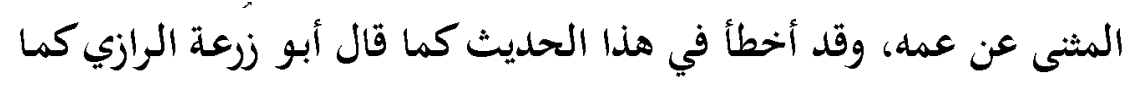

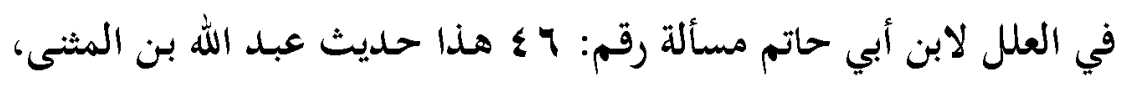

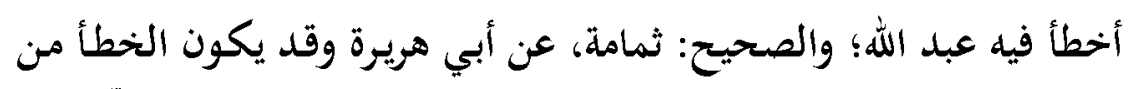

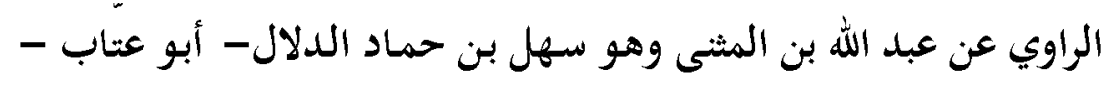

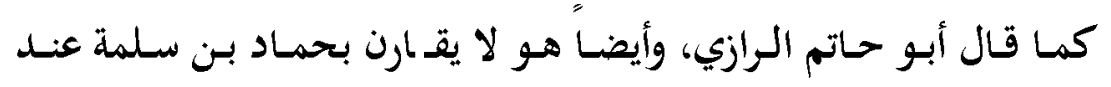

الترجيح.

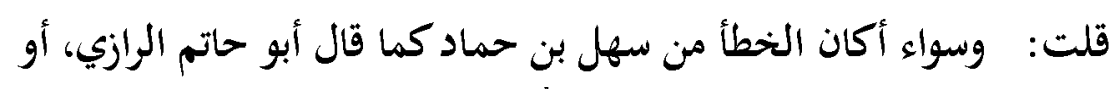

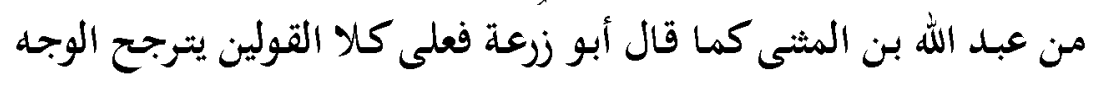

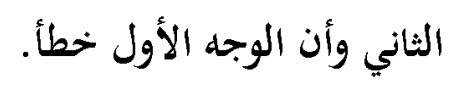
ـ ويلتقي هذا الترجيح مع ما ذهب الإليه أبو زرعة الرازي وأبو حاتم الرازي

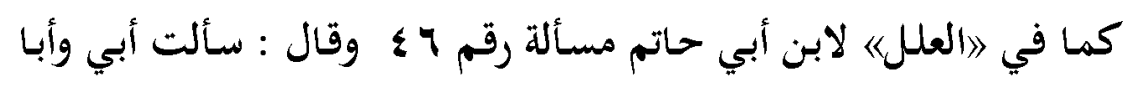

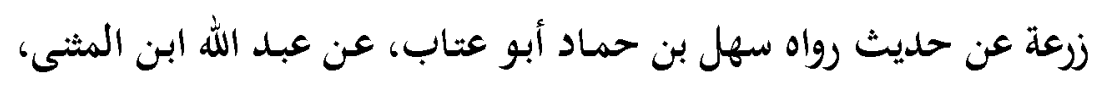

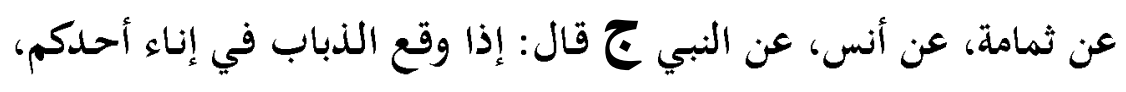

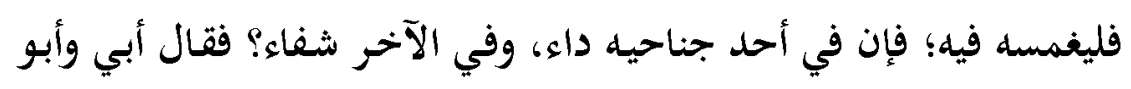
زرعة جميعا: رواه حماد بن سلمة، عن ثمامة بن عبد الله، عن أبي هريرة.

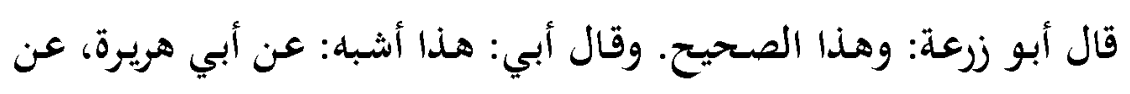




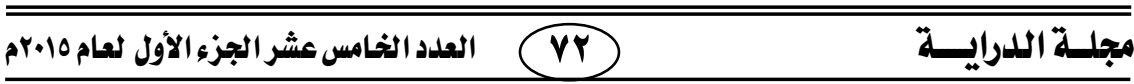

النبي ج ، ولزم أبو عتاب الطريق؛ فقال : عن عبـد الله، عن ثُمامـة، عن أنس. وقال أبو زرعة: هذا حـديث عبد الله بن المثنى، أخطأ فيه عبد الله؛ والصحيح: ثُمامة، عن أبي هريرة.

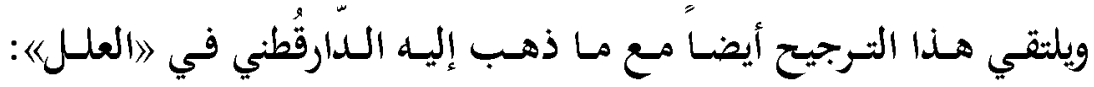

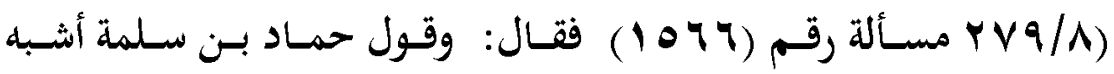

$$
\text { الحكم على الحديث : }
$$

الحديث من وجها الراجح؛ وإن كان رجاله ثقات إلاّ أنه ضعيف لإرساله.

$$
\text { قلت : ويرتقي بالثاهد الآتي إلى الصحيح لغيره . }
$$

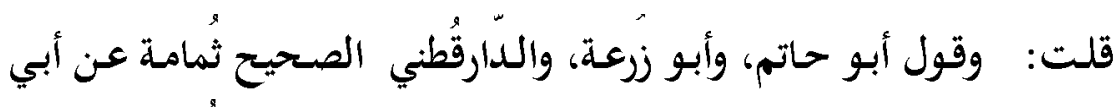

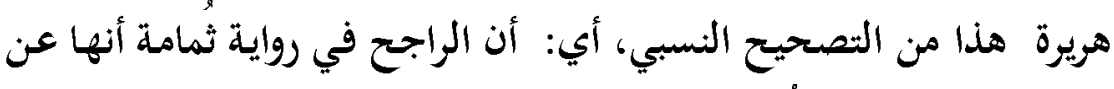

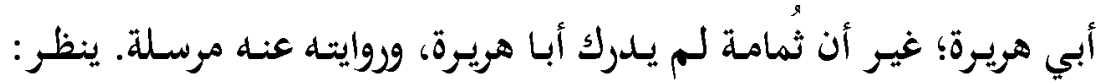

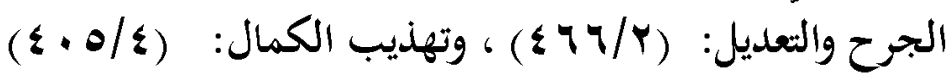

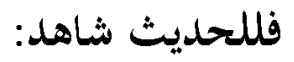

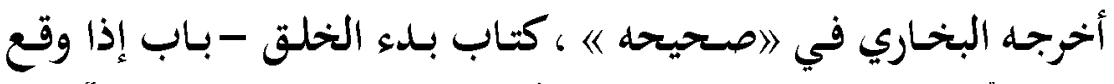

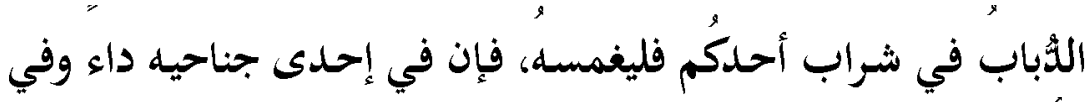

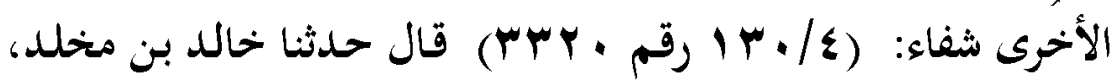
حـثنا سليمان بـن بـلال، قال: حـدثني عثبـة بـن مسـلم، قال: أخبرني عبيد بن حنين، قال: سمعت أبا هريرة رضي الله عنه، يقول: قال النبي

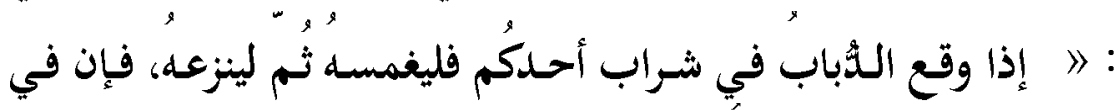

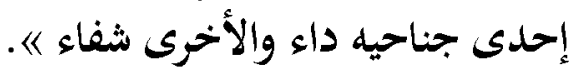




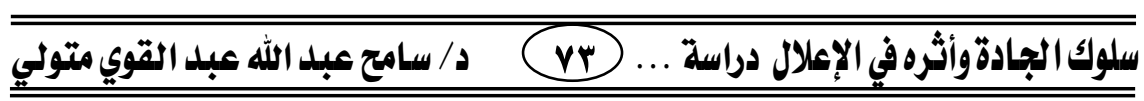

النظر في قرينة الاعلال وهى سلوك الجادة :

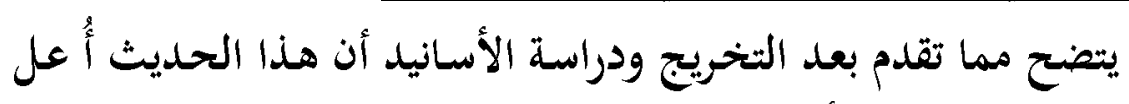

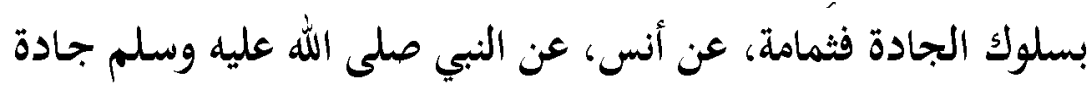

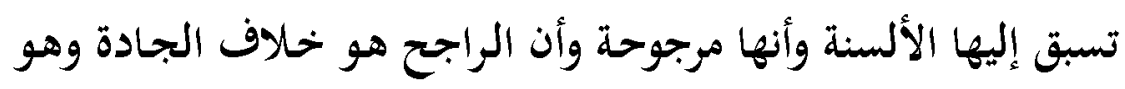

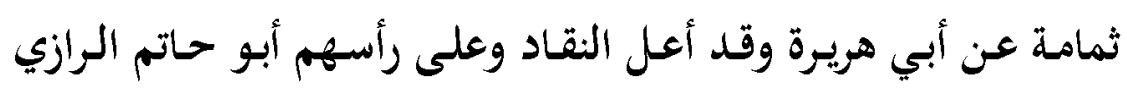
الحديث بهذه القرينة. 


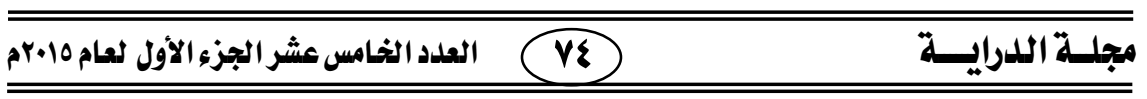

\section{المسألة الثانية}

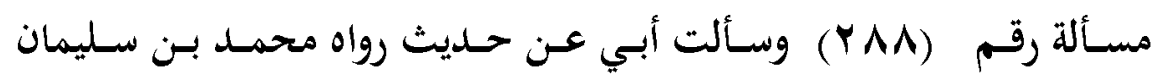

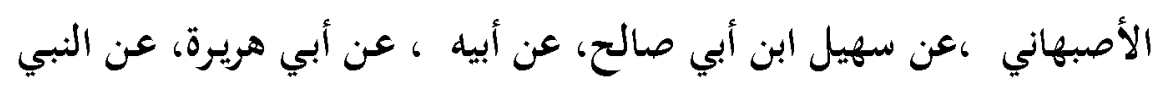

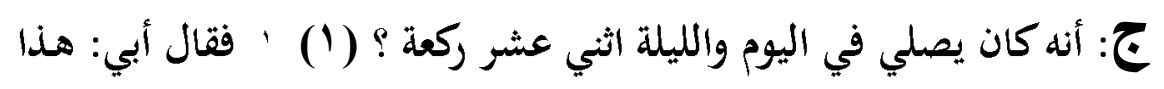

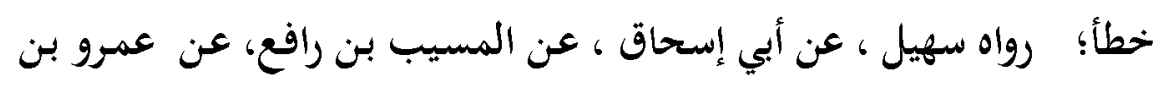

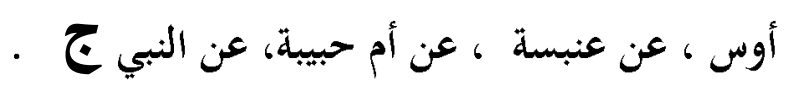

وقال أبي: كنت معجبا بهذا الحديث، وكنت أرى أنه غريب، حتى رأيت:

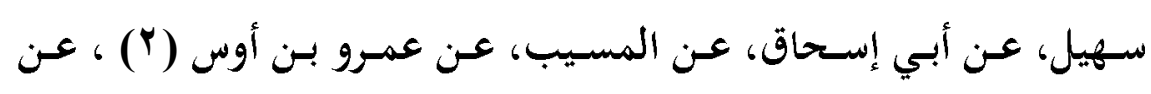

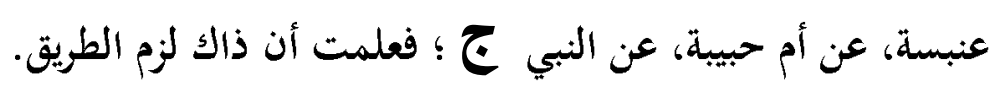
التخريج:

هذا الحديث يرويه سهيل بن أبي صالح واختلف عنه على وجهين:

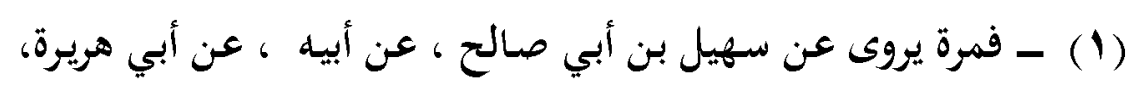

عن النبي ج ج (Y) - ومرة يروى عن سهيل بن أبي صالح، عن أبي إسحاق، عن المسيب،

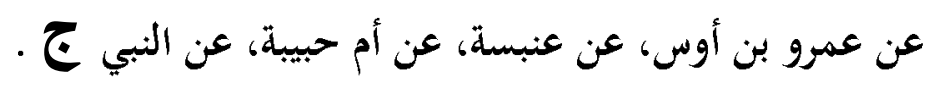

(1) نتبيه: لم نقف على اللفظ المذكور، وهو أن النبي ج كان يصلي في اليوم والليلة ... إلخ، وإنما

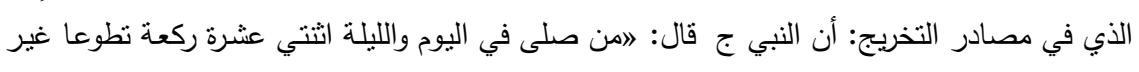
فريضة ،بنى الله له بينا في الجنة، أو : بني له بيت في الجنةه النه ، أو نحو هذا.

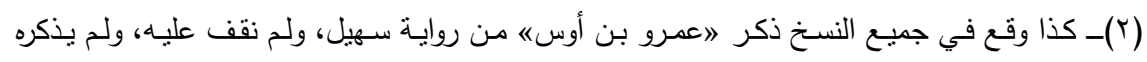
الدارقطني في "العلل" عند عرضه للاختلاف في الحديث. 


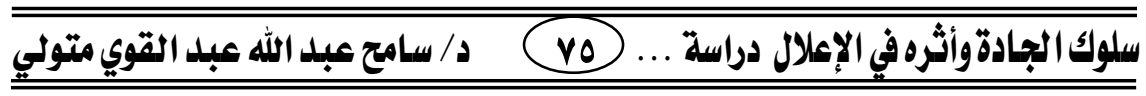 \\ الوجه الأول:}

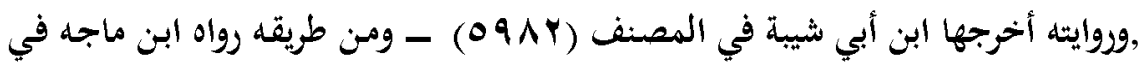
سننه، كتاب إقامة الصلاة، والسنة فيها ــ باب ما جاء في في فئني عشرة ركعة من السنة - $(1) \leqslant r)$

النسائي في المجتبى ،كتاب قيام الليل وتطوع النهار (1111) ، وفي

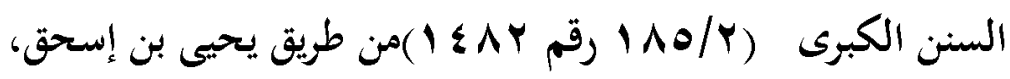

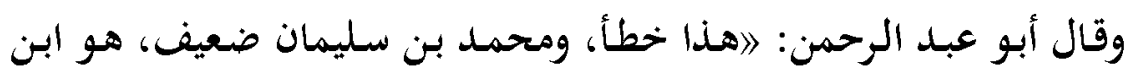

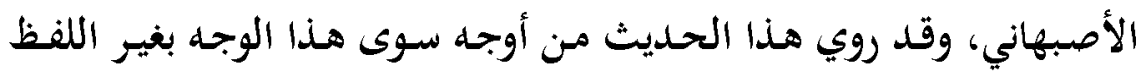

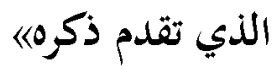

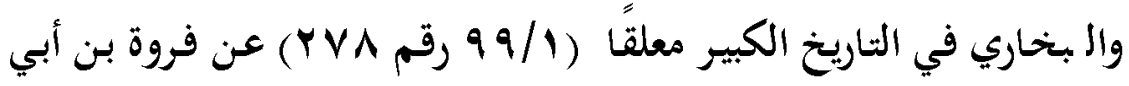

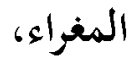

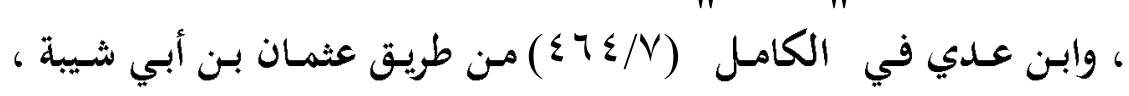

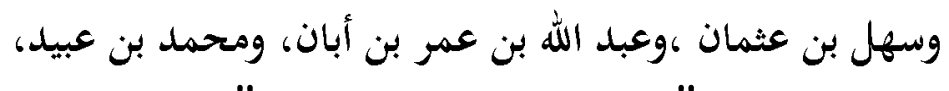

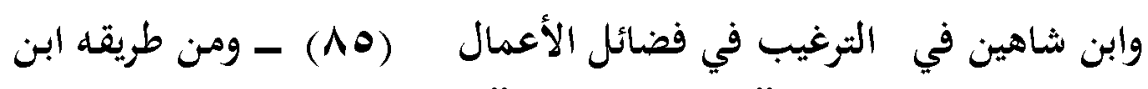

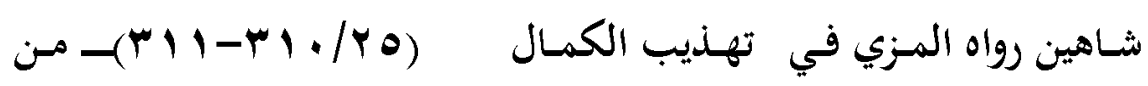
طريق علي بن سعيد بن مسروق الكندي،

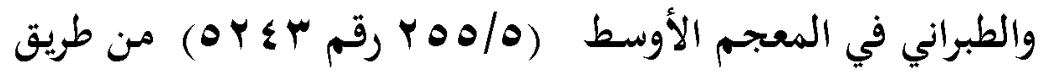

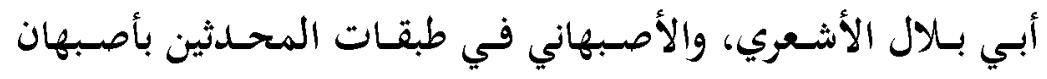

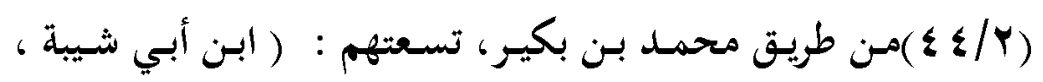




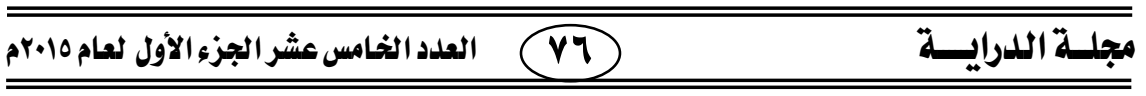

ويحيى بن إسحاق ، وفروة بن أبي المفراء ، عثمان بن أبي شيبة ،

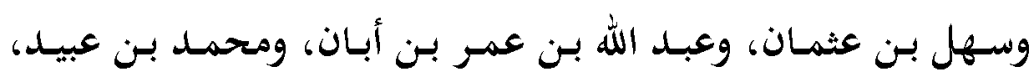

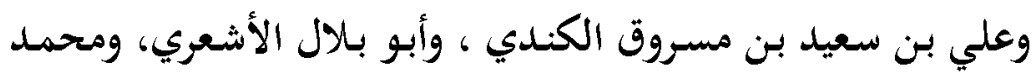

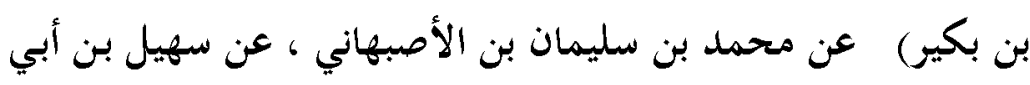

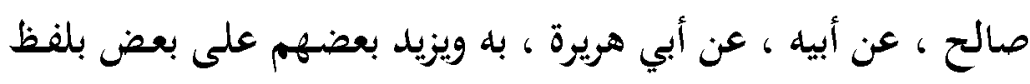

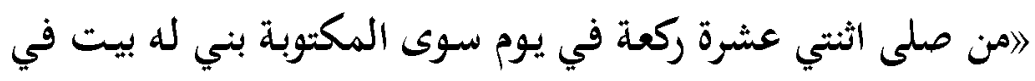

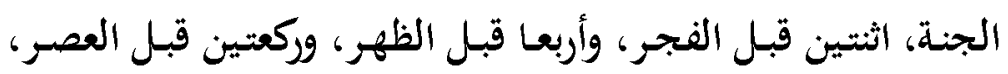

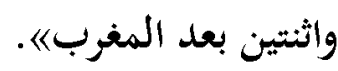
وزاد ابن أبي شيبة و وأظنه قال: وركعتين بعد العشاء. الوجه الثانى: ومرة يروى عن سهيل بن أبي صالح، عن أبي إسحاق، عن المسيب، عن عمرو بن أوس، عن عنبسة، عن أم حبيبة، عن النبي ج وروايته أخرجها النسائي في المجتبى ،كتاب قيام الليل وتطوع النهار ـ باب ثواب من صلى في اليوم والليلة ثنتي عشرة ركعة سوى المكتوبة .........

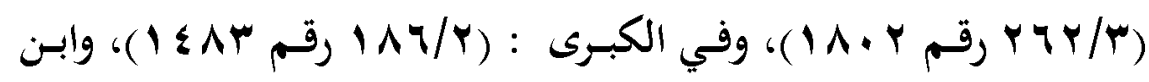

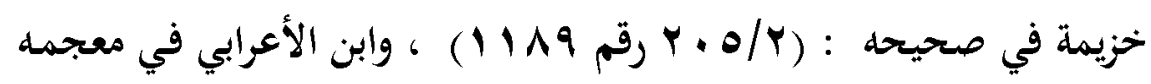

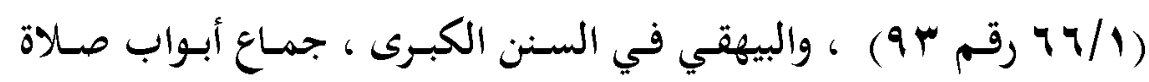

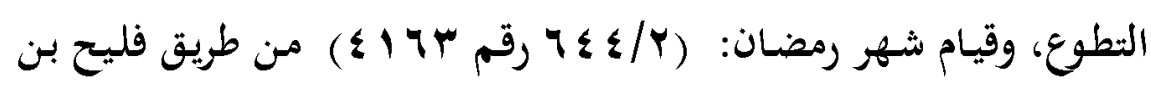
سليمان، عن سهيل، بن أبي صـالح، عن أبي إسحاق، عن المسيب، عن

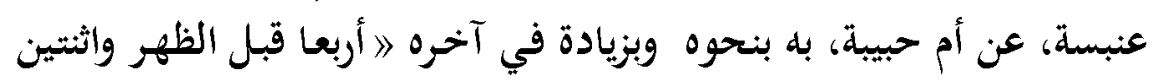

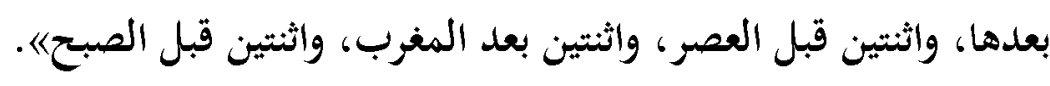




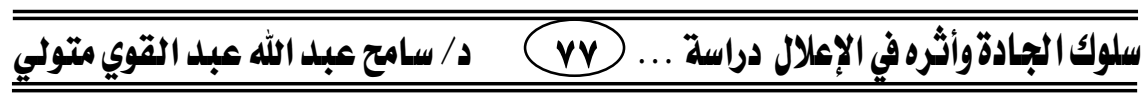

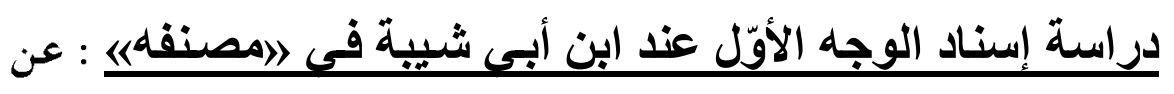

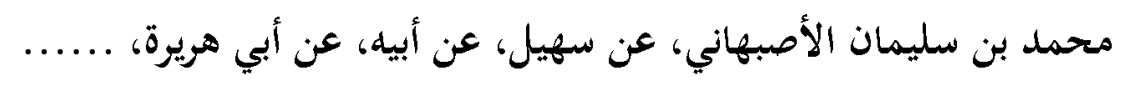

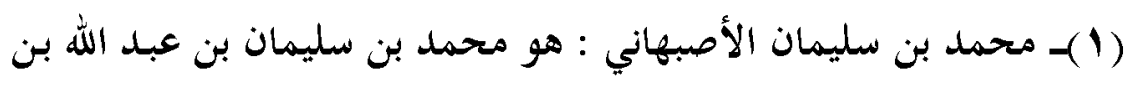

الأصبهاني، أبو علي الكوفي.

روى عن: أبيه ، وسهيل بن أبي صالح، ويحيى بن عبيد، وغيرهم.

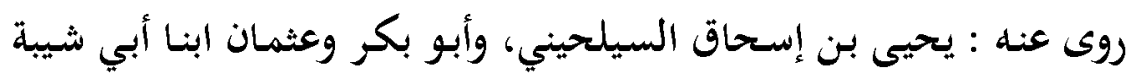

$$
\text { كوغ أبرهم. }
$$

قال أبو حاتم: لا بأس به يكتب حديثه ولا يحتجن بله.

وقال أبي عدي: مضطرب الحديث قليل الحديث ومقدار ماله قد أخطأ

$$
\text { في غير شيء منه. }
$$

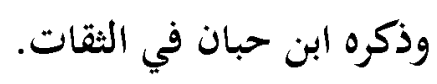

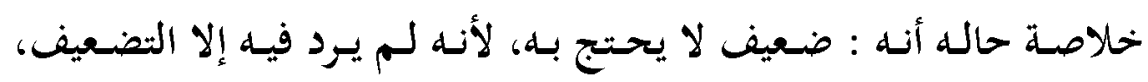

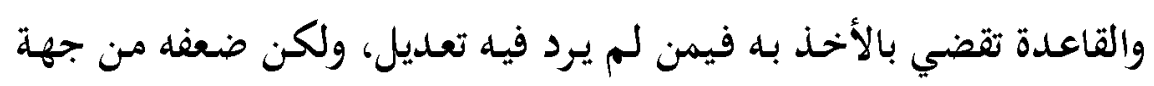
حفظه فهو محتمل.

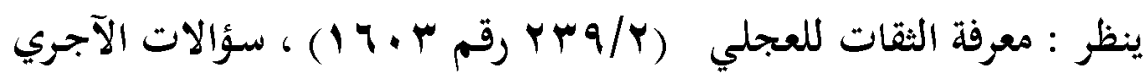

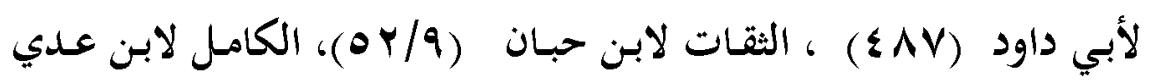

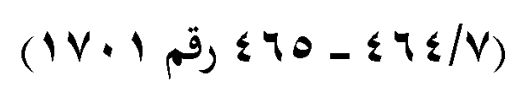

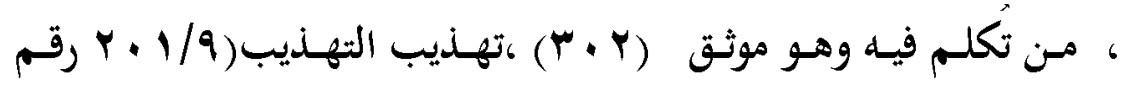

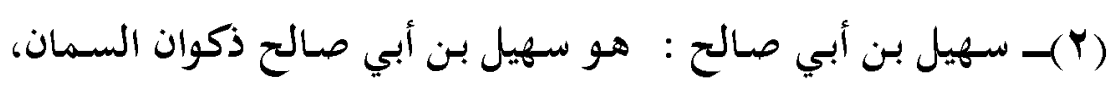




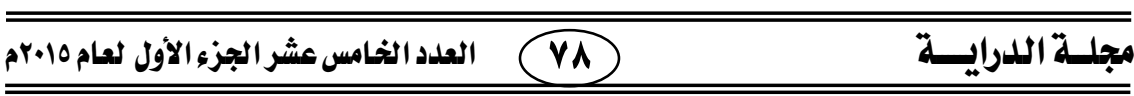

خلاصة حاله أنه : ثقة، فأكثر الأئمسة على توثيقه، وروى عند كبار الأئمة،

$$
\text { واحتج به مسلم كثيرا في صحيحه . }
$$

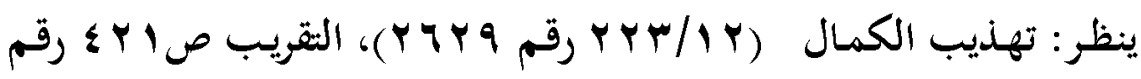
. .

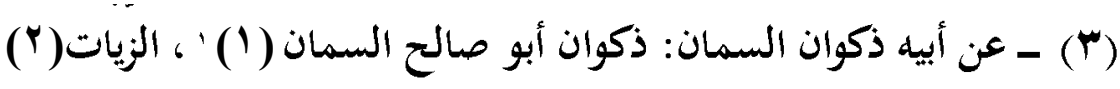

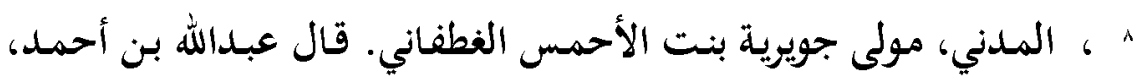

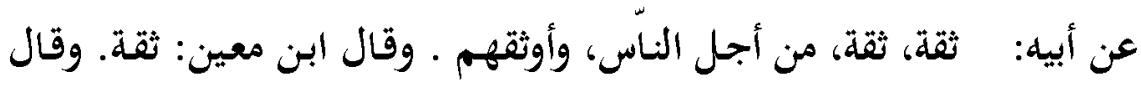
أبو حاتم: ثقة صالح الحديث يحتج بحديثله.

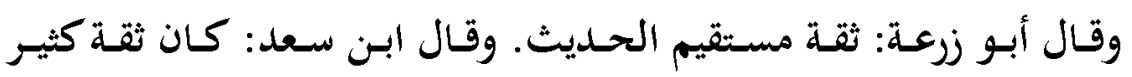
الحـديث. وقال السـاجي: ثقـة صسدوق. وقال الحربي: كـان مـ الثّات.

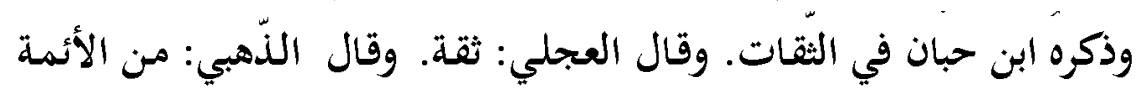

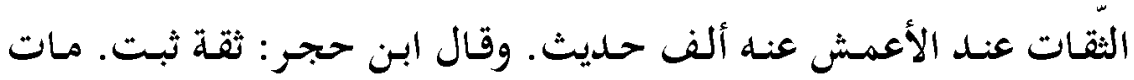
بالمدينة سنة 1 1 الهـ

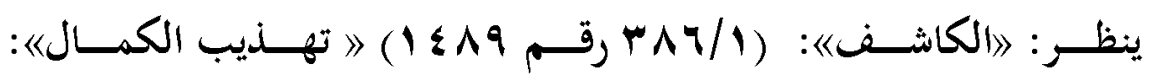

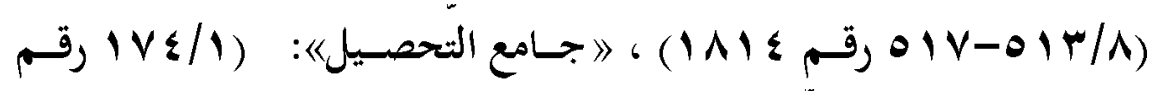

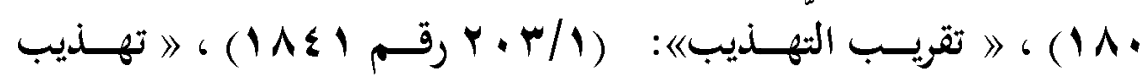

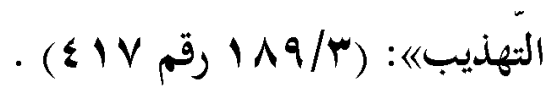

(1) الستَّان: بفتح السين المهملة وتثديد الميم وفي آخرها النون، هذه النسبة إلى بيع السمن. ينظر :

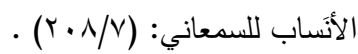

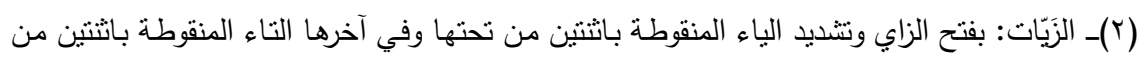

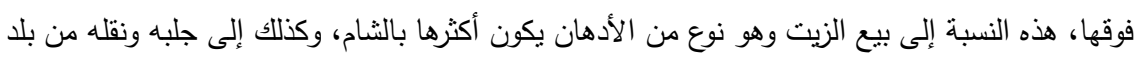

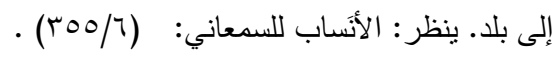




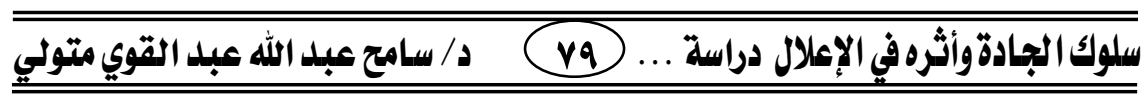

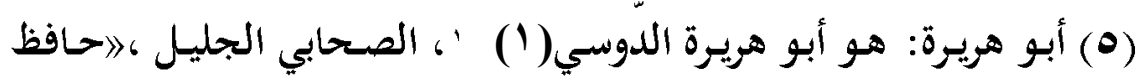

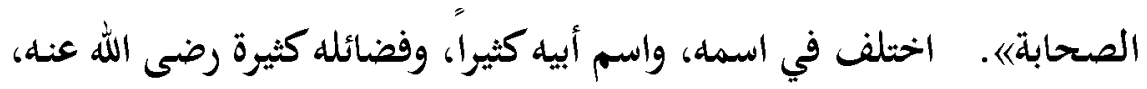

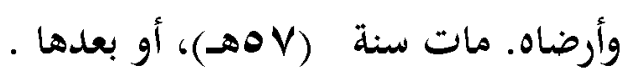

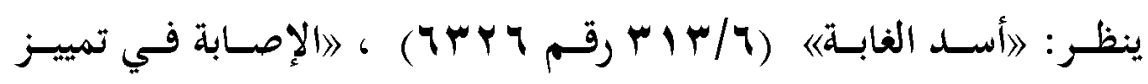

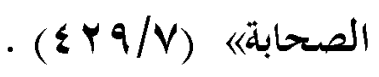

دراسة إسناد الوجه الثاني عند النسائي في المجتبى : أخبرنا أبو الأزهر أحمد

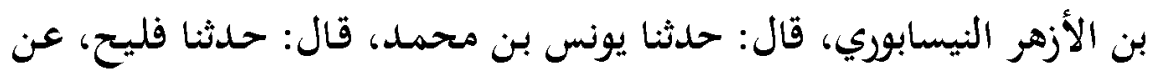

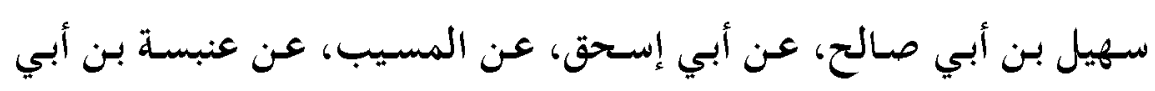

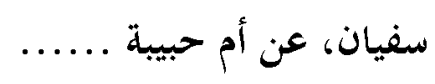

(1) - أبو الأزهر أحمد بن الأزهر النيسابوري: هو أحمد بن الأزهر بن منيع

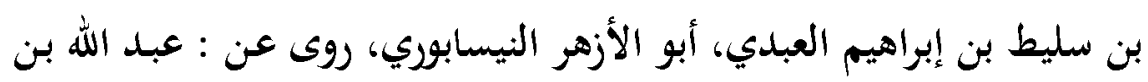

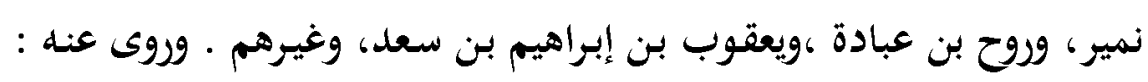

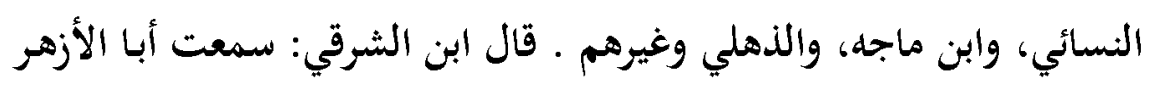

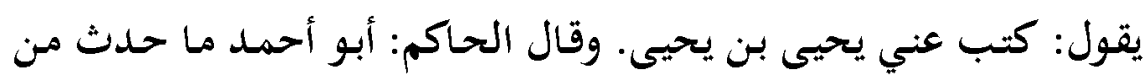

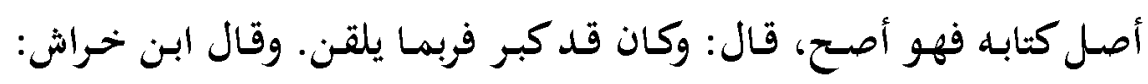

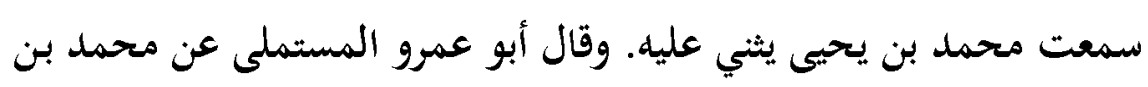

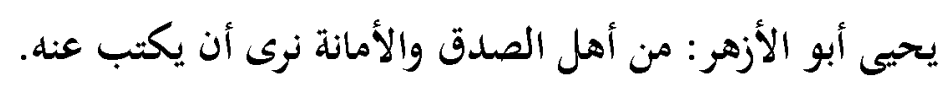

( (1)ـ الدَّونسي: بفتح الدال المهملة وسكون الواو وكسر السين المهملة، هذه النسبة إلى دوس. ينظر :

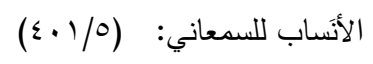




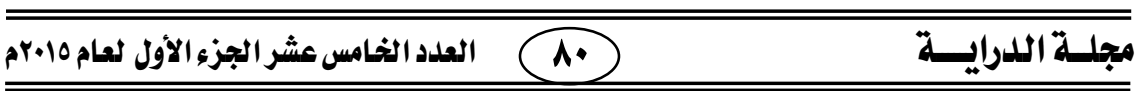

وقال مكي بن عبدان: سألت مسلم بن الحجاج عن أبي الأزهر، فقال اكتب عنه وقال إبراهيم بـن أبي طالب: كان مـن أحسن مشـايخنا حسديثا. وقـال أحمـد بـن سـيار: حسـ الحسديث. وقـال صـالح جـزرة: صسدوق. وقـال النسائي، والدارقطني: لا بأس بـه. وقال الدارقطني: قد أخرج في الصحيح عن من هو دونه وشر منه ، ولما ذكر ابن الشرقي بنادرة الحديث عده فيهم • وقال أبو حاتم: صدوق . وقال ابن شاهين في الأفراد له: ثقة نبيل .وذكره ابن حبان في الثقات وقال: يخطئ وكان ابن خزيمة إذا حدث عنده قال : ثنا

$$
\text { خابلاصة حاله أنه : ألهر من أصل كتابله. }
$$

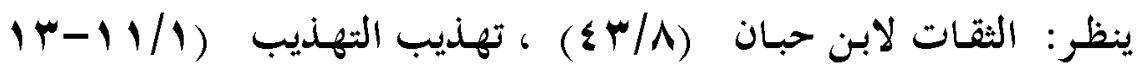

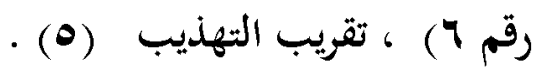

(Y) - يونس بن محمدل: هُو يونس بن محمد بن مسلم البغدادي، أبو

محمد الحافظ، المؤدبّ.

روى عن: داود بن أبي الفُ رات، وحرب بن ميمون، واللّيث بن سعد، وغيرهم

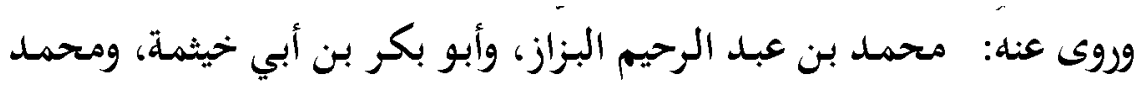
بن عبيد الله بن المنادي، وآخرون.

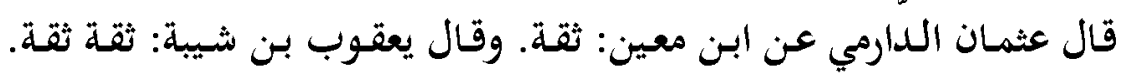

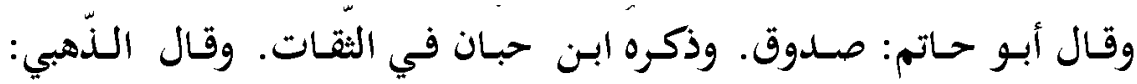
الحافظ الثقة. وقال ابن حجر : ثقة ثبت خلاصة حاله أنه: ثقة، وأما قول أبي حاتم فلم أجد ما يؤيده. 


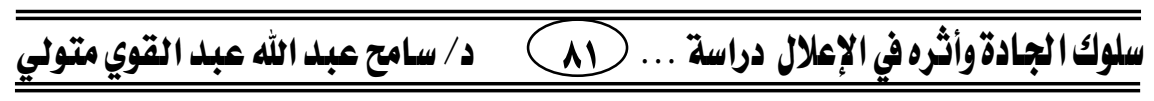

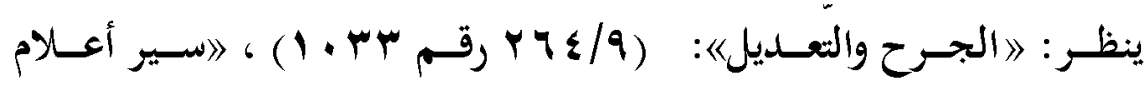

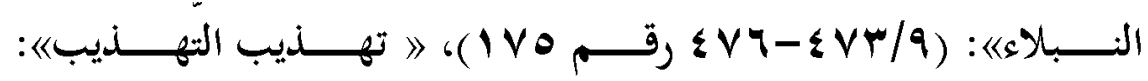

:

$$
\text { . (Vq1 }
$$

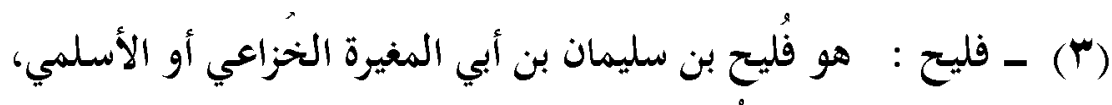

المدني، أبو يحيى. يقال: فُليح: لقب لهي له، واسمه عبد الملك.

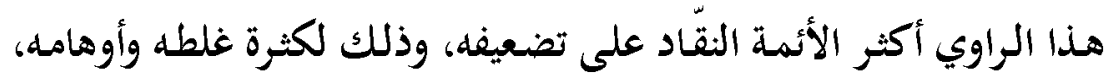

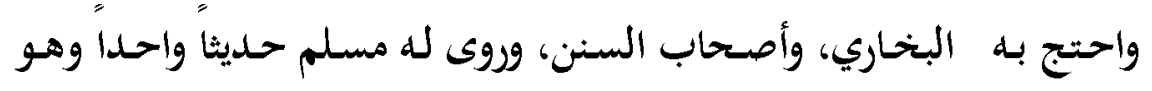
حديث الإفك. وقال النسائي : ليس بالقوي.

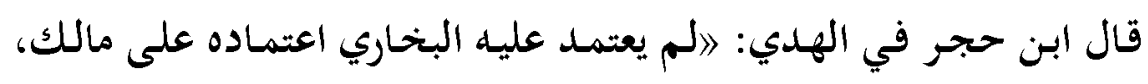

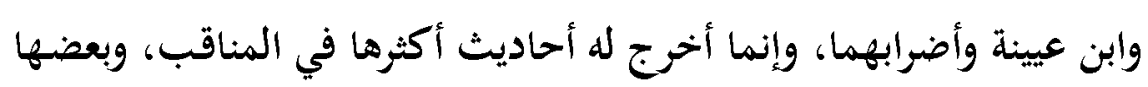

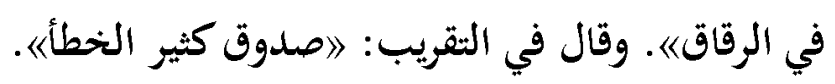

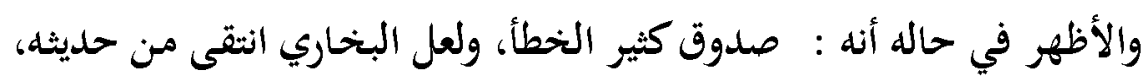

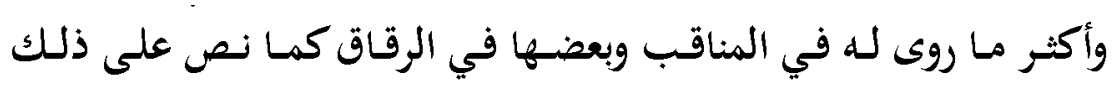

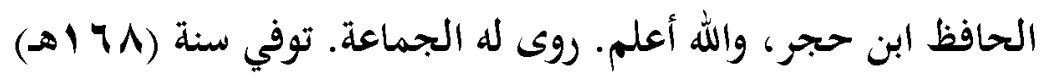

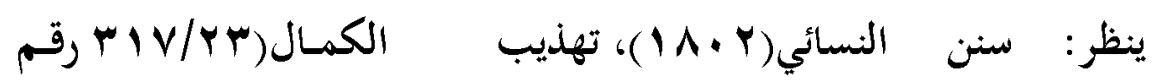

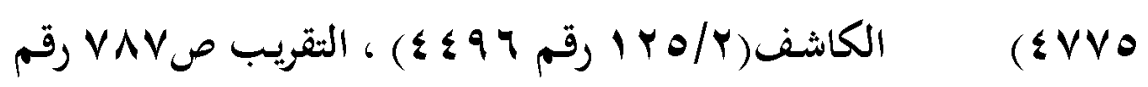
(\&) (\&) - سهيل بن أبي صالح: ثقة . تقدمت ترجمته في الوجه الأول. 


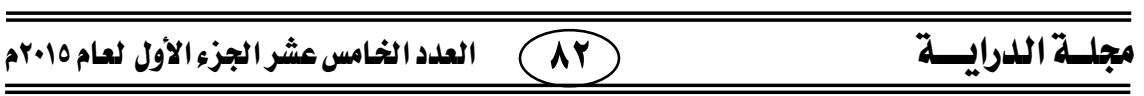

(0) - أبو إسحق : هو عمرو بن عبد الله بن عبيد ،ويقال: علي، ويقال: ابـن أبي شعيرة السـبيعي، الهمـداني، الكـوفي، مشـهور بكنيتـه، أحسد أئمسة التابعين، ولد لسنتين بقيتا من خحلافة عثمان بن عغان . روى عـن : الزبيـر بـن عسدي، وابـن عبــاس ، وخلـق كثيـر مـن الصـحابة، والتـابعين، وعنـه: عمـار بـ رزيق، والثوري- وهـو أثبـت النـاس فيـه، وقيل:

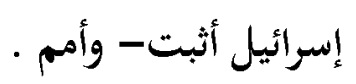
أطلق القول بتوثيقه ابن معي نن، والنسائي، والعجلي، وأبو حاتم، واحتج بـهـ الشيخان. وقال الإمام أحمد: 》اثقة). وذكره ابن حبان في الثقات، وقال:

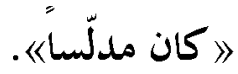
وقد وصفه عدد من الأئمة بالتدليس، قال الإمام أحمد: 》امـا أفسد حديث

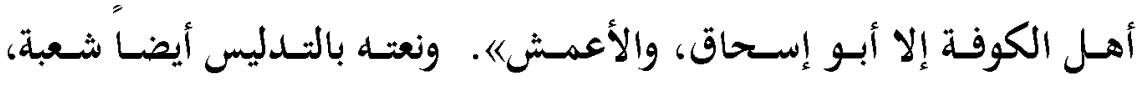
ويعقوب بن سفيان، والنسائي ،والدارقطني، والبيهقي، وحسين الكرابيسي، إلهي، وأبرو جعفر الطبري، وآخـرون، وذكره العلائي في جـامع التحصيل، وجعله هو، وابن حجر في تعريف أهل التقديس في رجال المرتبة الثالثة من مراتب

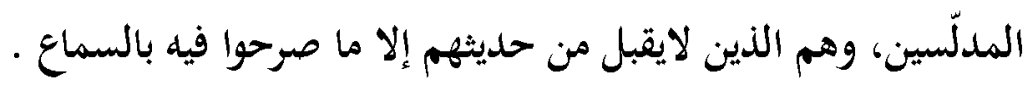
قلت: إلا ما رواه شعبة عنه فهو متصل؛ لأنه قال: 》 اكفيتكم تدليس ثلاثة: الأعمش، وأبو إسحاق، وقتادة/،.

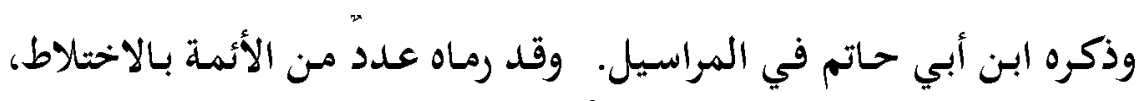
أشـار إلى ذلك الإمام أحمد، ونص عليه أبو زرعة الرازي، و وابن الصـلاح، وهو ما ذهـب إليه ابن حجر في التقريب، وقال في هدي السـاري: \أحد الأعلام الأثبات قبـل اختلاطه، ولم أر في البخـاري من الروايـة عنه إلا عـن 


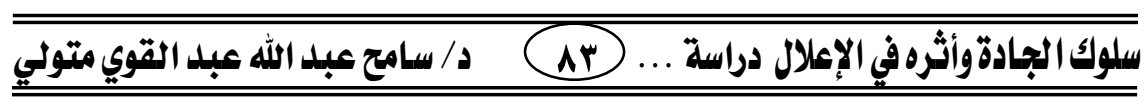

القدماء من أصحابه كالثوري، وشعبة، لا عن المتأخرين كابن عيينة، وغيرها.

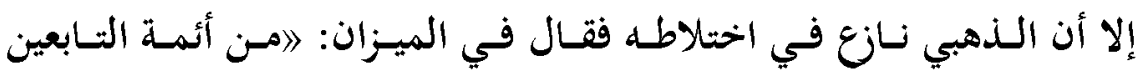

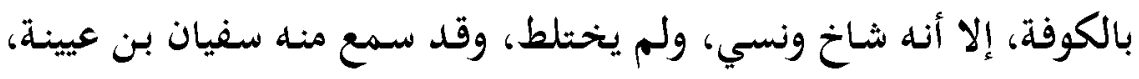

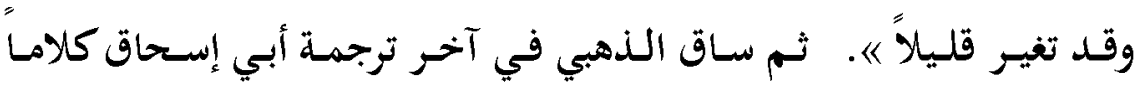
ليعقوب بن سفيان، حكى فيه عن بعض أهل العلم أنه اختلط، وأنهم تركوه مع ابن عيينة؛ لاختلاطه، ولم يتعقبه بشيء .

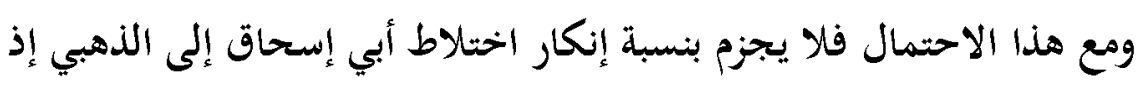

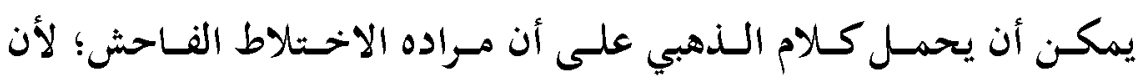

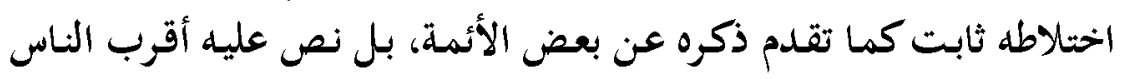

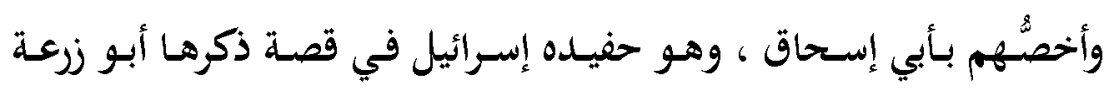

الدمشقي بإسناده، عن عبيد الله بن عمرو قال : إقلت للإسرائيل:

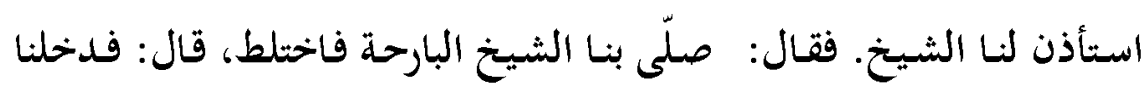

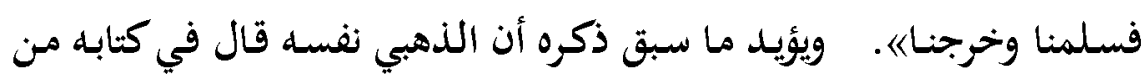

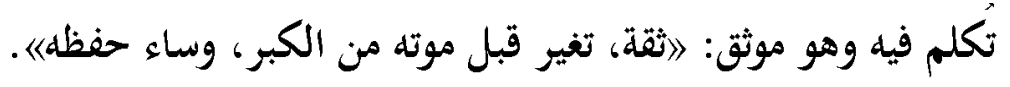

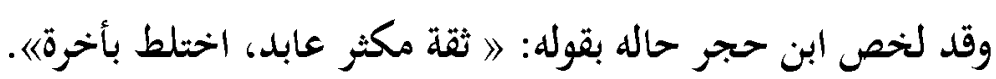

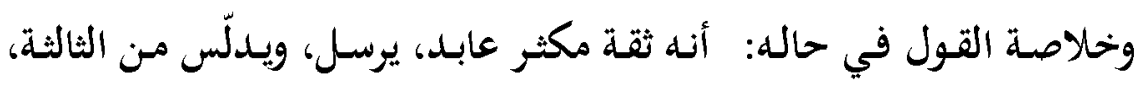

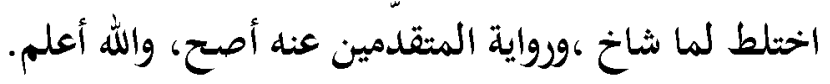

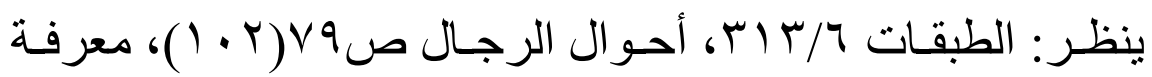

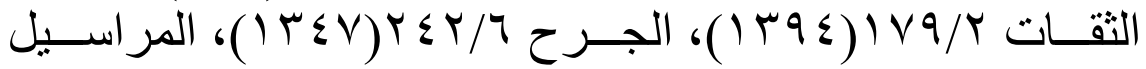

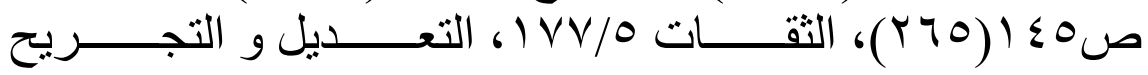

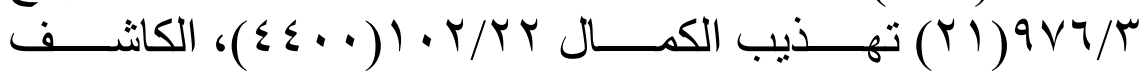

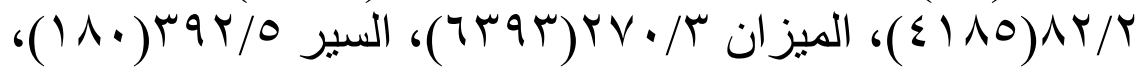

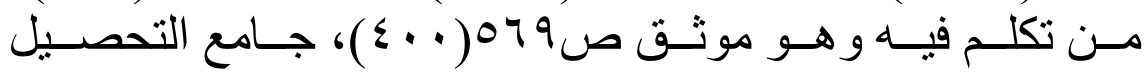




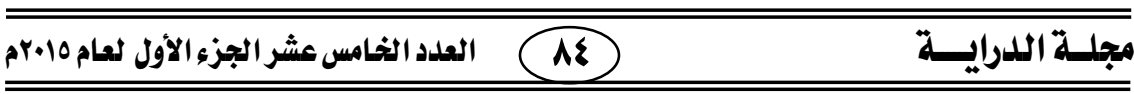

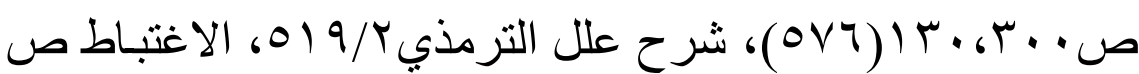

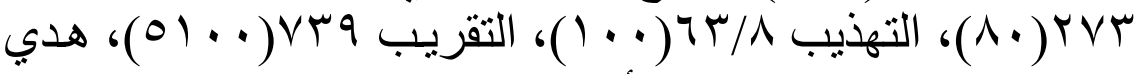

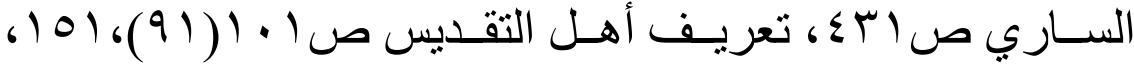

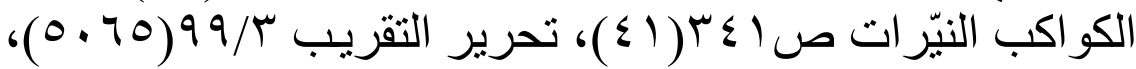

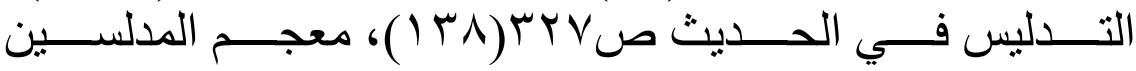

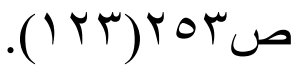
(7) - المسيب : هو المسيب بن رافع الأسدي، الكاهلي، أبو العلاء

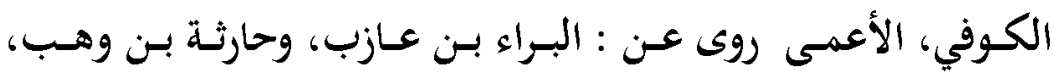
وخرشة بن الحر، وغيرهم.

روى عنه: ابنه العلاء، وأبو إسحاق السبيعي، والأعشى، وغيرهم. قال ابن معين : ثقة . وقال العوام بن حوشب : كان المسيب يختم القرآن في كل ثلاث ـ ـوذكره ابن حبان في الثقات. وقال العجلي تابعي ثقة. وقال ابن حجر : ثقات النة. خلاصة حاله أنه : ثقة.

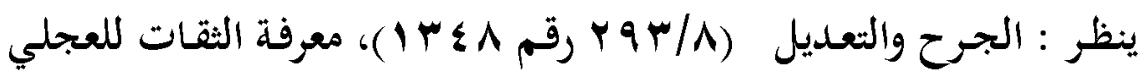

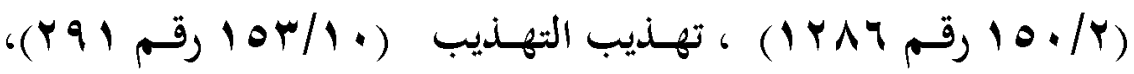
تقريب التهذيب (TV0) (TV0).

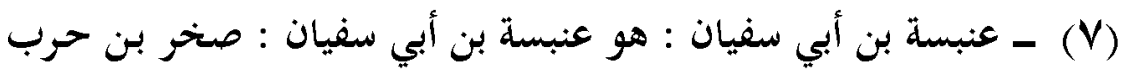

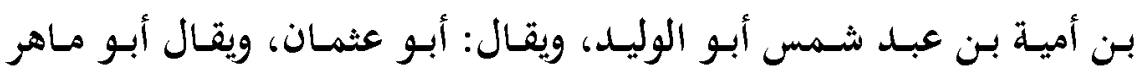

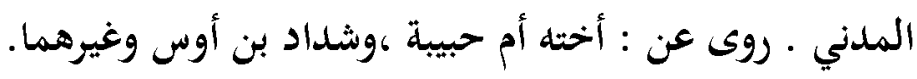

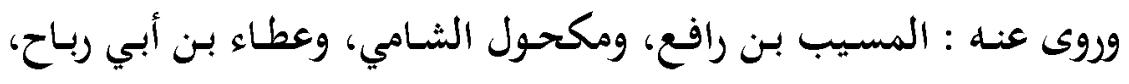
وغيرهم 


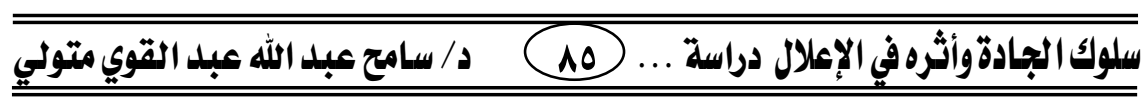

قال أبو نعيم الأصبهاني: أدرك النبي صلى الله عليه وسلم لا تصح له صحبة

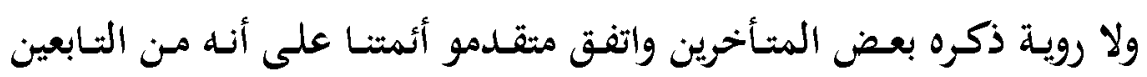

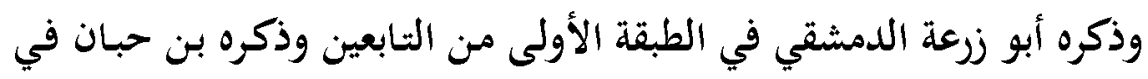
ثقات التابعين.

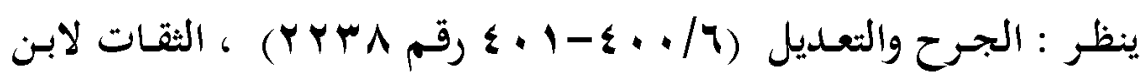

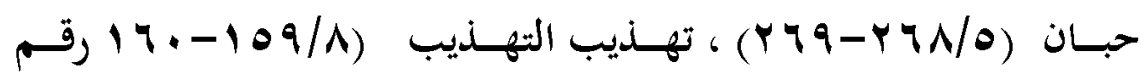

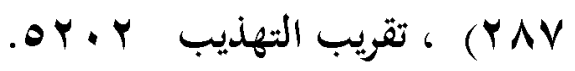

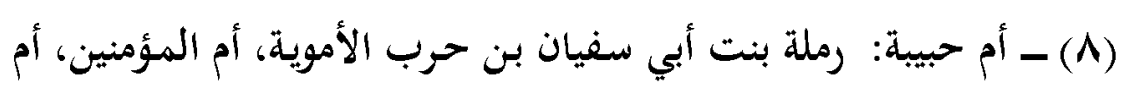

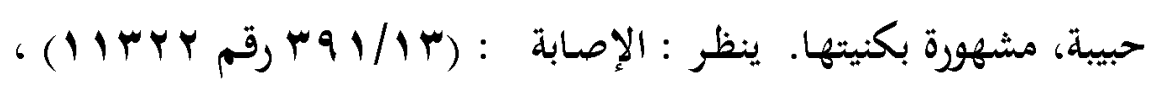

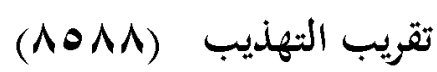
النظّر والترجيح:

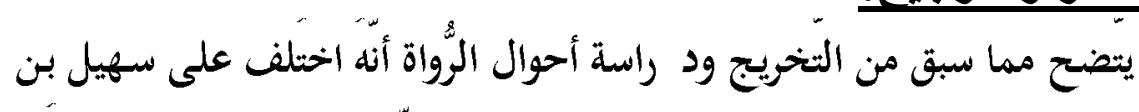

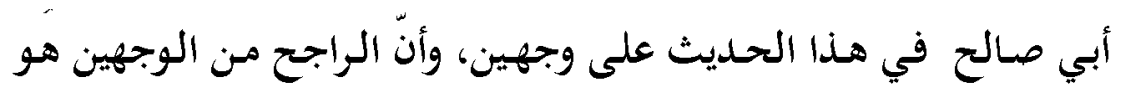

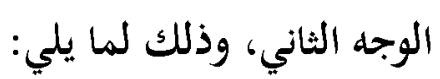

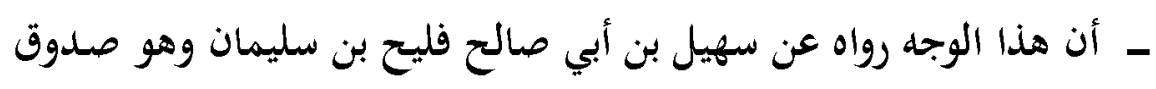

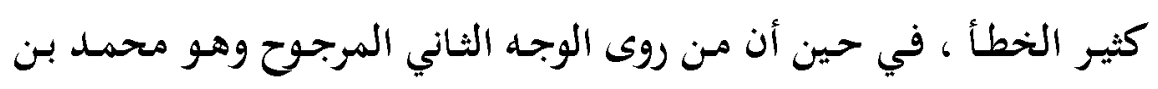
سليمان الأصبهاني وهو ضعيف كما تقدم من حاله.

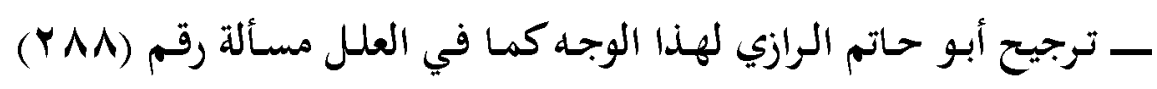

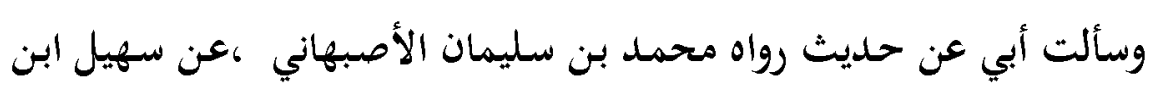

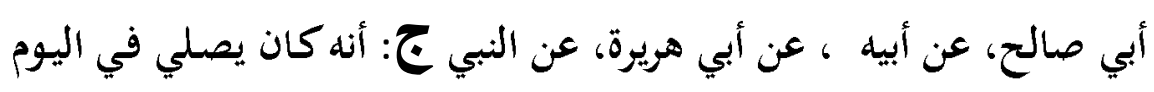

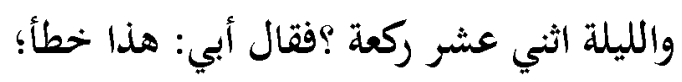




\section{\begin{tabular}{lll}
\hline \hline مجلـة الدرايـــة & \\
\hline \hline
\end{tabular}}

رواه سهيل ، عن أبي إسحاق ، عن المسيب بن رافع، عن عمرو بن أوس

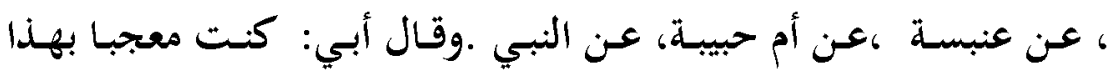

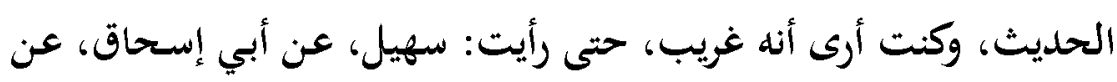

المسيب، عن عمرو بن أوس، عن عنبسة، عن أم حبيبة، عن النبي ج ؛

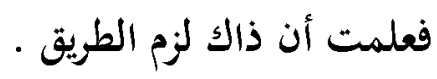

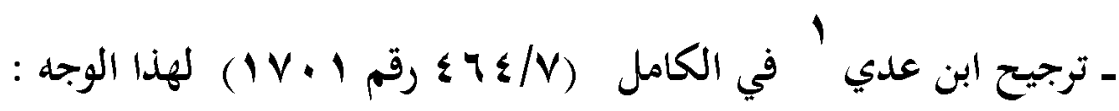
》وهذا أخطأ فيه ابن الأصبهاني حيث قال: عن سهيل، عن أبيه، عن أبي

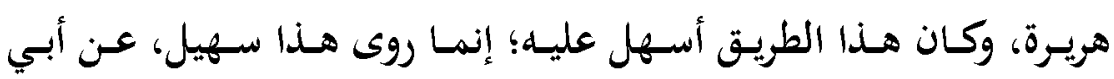
إسحاق، عن عنبسة بن أبي سفيان، عن أم حبيبة، .

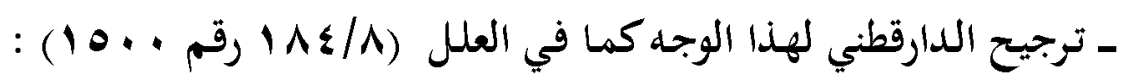
فقال \ايرويه سهيل بن أبي صالح، واختلف عند؛ فرواه محمدل بن سليمان الأصبهاني وأيوب بن سيار، عن سهيل بن أبي صـالح، عن أبيه، عن أبي

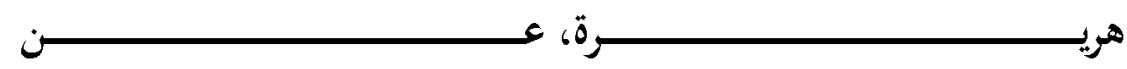
النبي ج ، ووهمـا فيـه. ورواه فلـيح بـن سـليمان، عـن سهيل، عـن أبي إسحاق السبيعي، عن المسيب بن رافع، عن عنبسة ابن أبي سفيان، عن أم حبيبة ، وقول فليح أشبه بالصوابه . ـ خطأ الوجه المرجوح كما قال النسائي (ح رقم | ومحمد بن سليمان ضعيف، هو ابن الأصبهاني" .

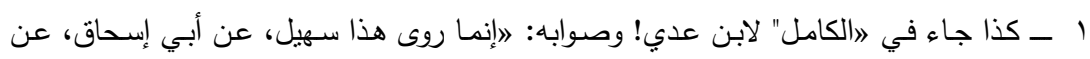

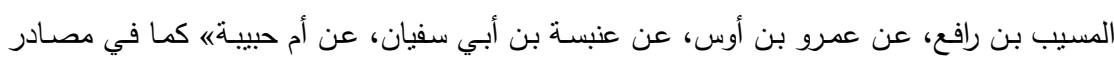




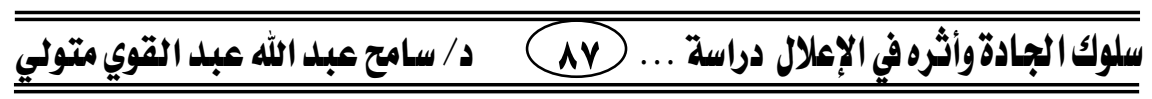

\section{الحكم على الحديث:}

الحديث من وجها الراجح ضعيف ؛ لحال فليح بن سليمان كما تقدم في

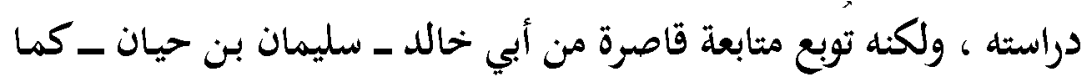

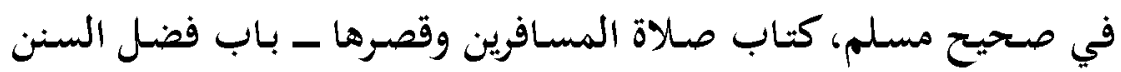

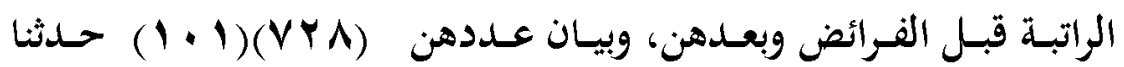

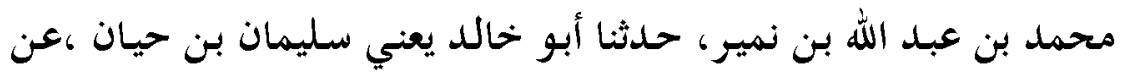

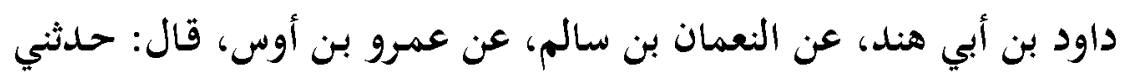

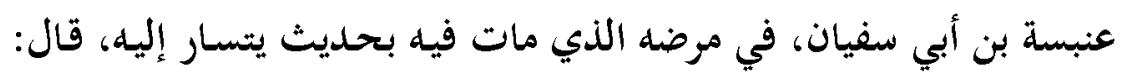

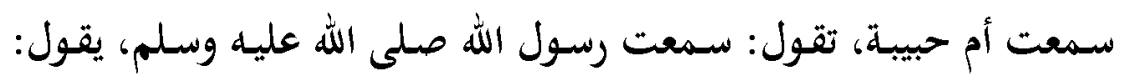

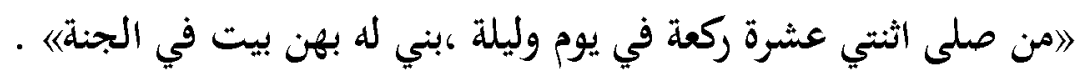
فيرتقي بها الحديث إلى صحيح لغيره.

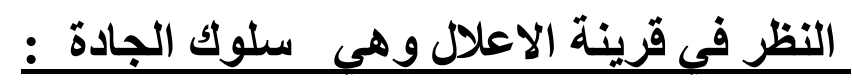

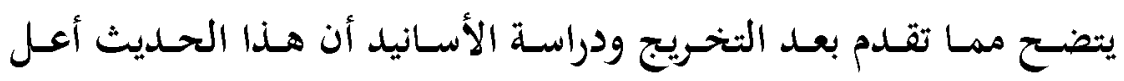

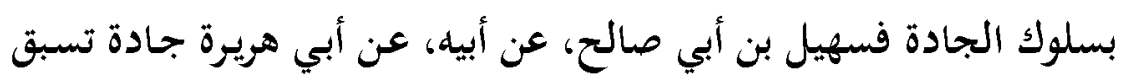

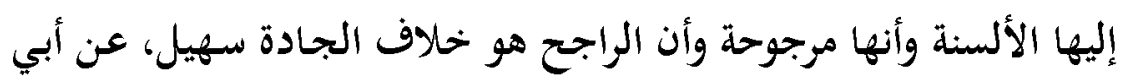

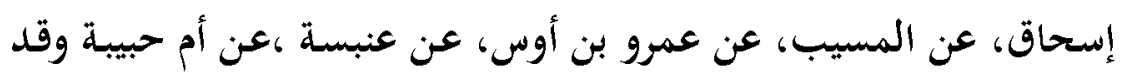

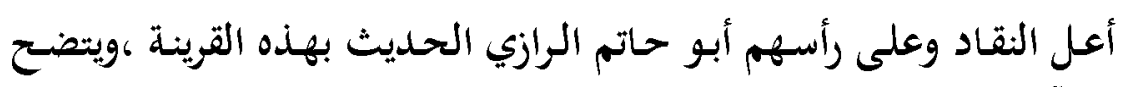

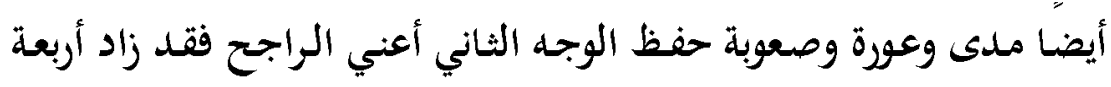
من الرواة فحفظهم بهذا السياق يحتاج إلى مزيد ضبط وإتقان. 


\section{\begin{tabular}{lll}
\hline \hline مجلـة الدرايـــة & \\
\hline \hline
\end{tabular}}

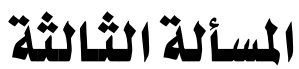

مسألة رقم (ONY) وسألت أبي عن حديث رواه ابن أبي ذئب ، عن

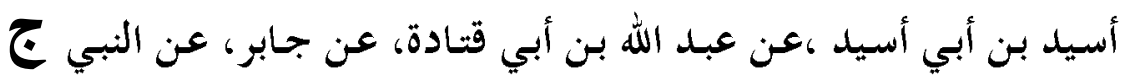

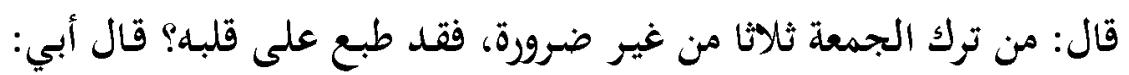

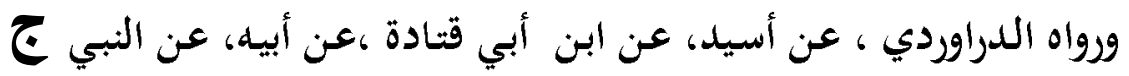

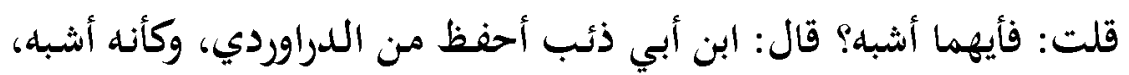

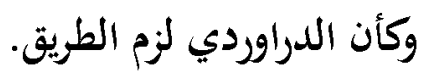
التخريج:

هذا الحديث يرويه أسيد بن أبي أسيد واختلف عنده على وجهين:

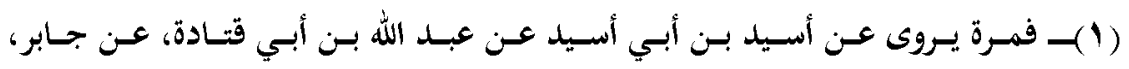

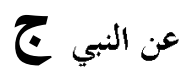
(T) ـ ومرة يروى عن أسيد، عن ابن أبي قتادة، عن أبيه،

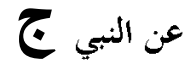

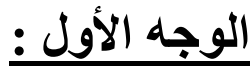

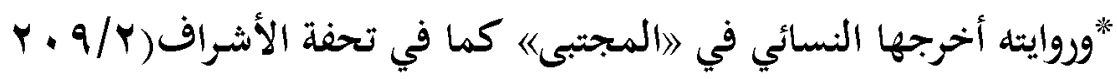

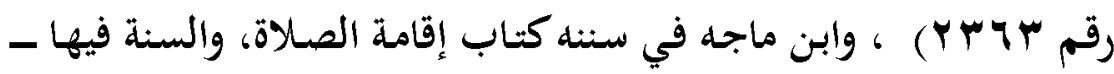

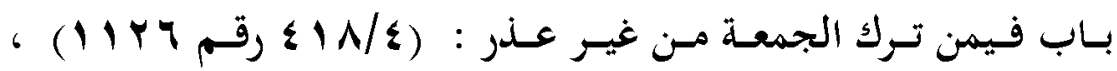

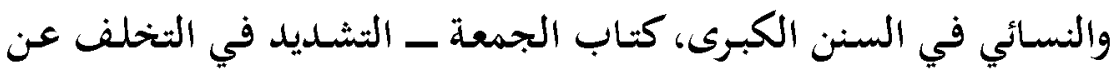

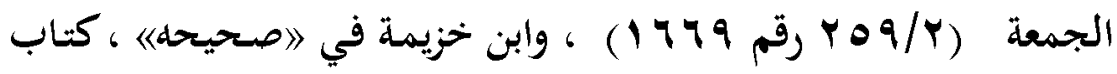

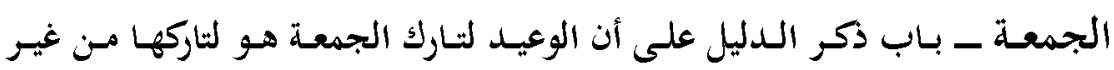

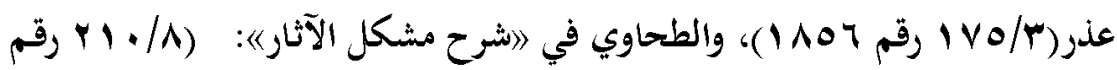

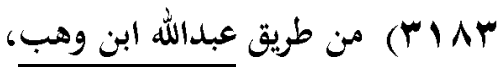




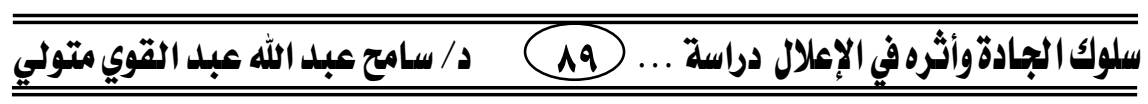

وابن خزيمة في اصحيحلها، كتاب الجمعة - ـ باب ذكر الدليل على أن

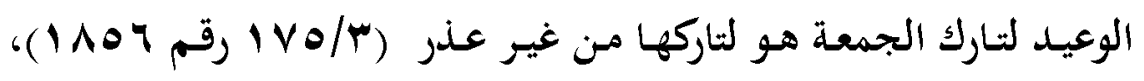

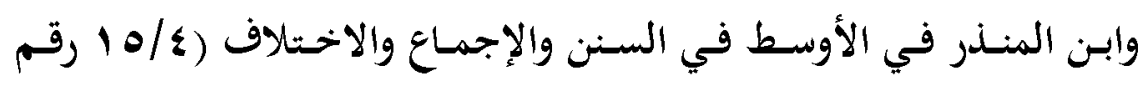

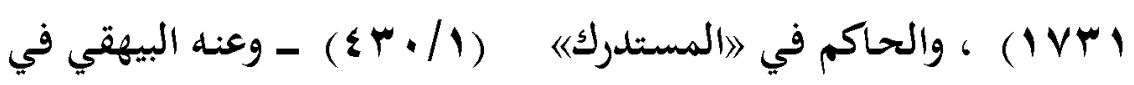

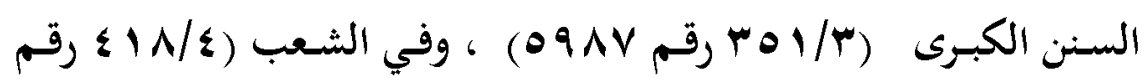
§

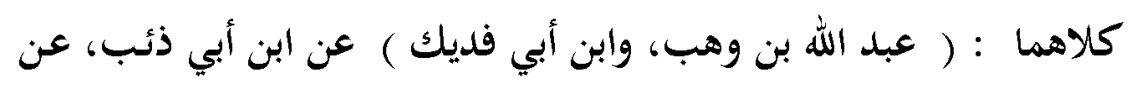

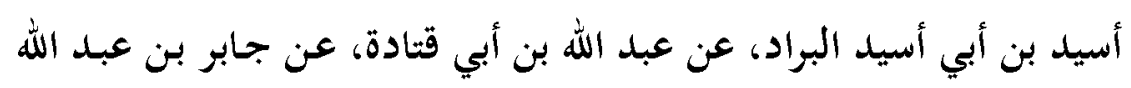

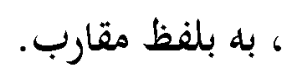

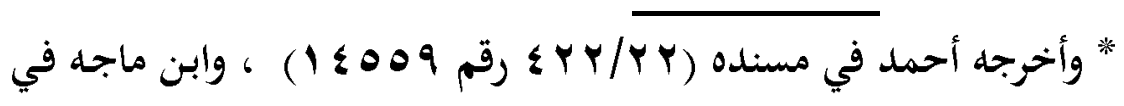

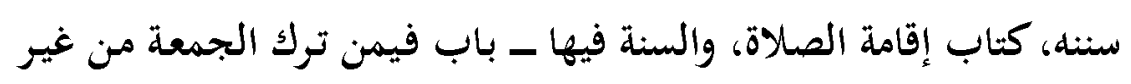

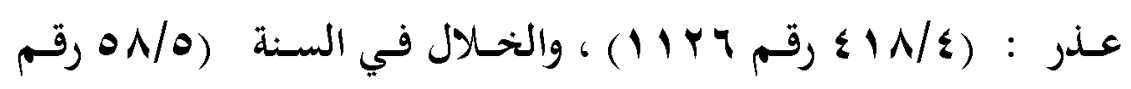

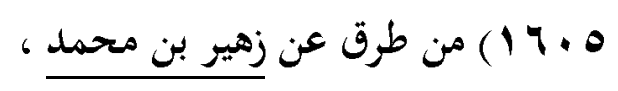

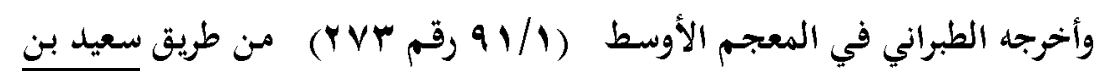
أبي أيوب، كلاهما : (زهير، وسعيد بن أبي أيوب ) عن أسيد، عن عبد الله بن أبي قتادة، عن جابر بن عبد الله، بله الوجـه الثـانىي: ومرة يـروى عن أسيد، عن ابن أبي قتـادة، عن أبيه، عن النبي ج

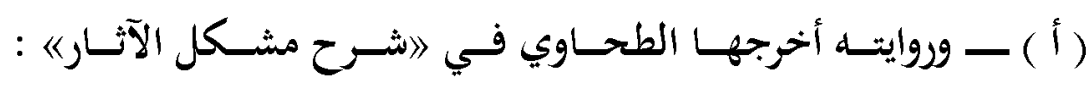

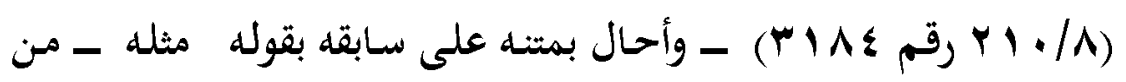




\section{مجلـة اللدرايـــة"ة}

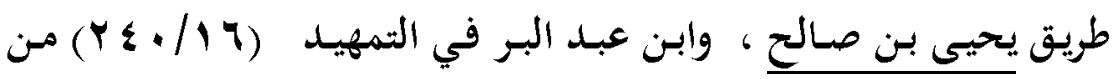
طريق داود بن عبد الله الجعفري، كلاهما : (يحيى بن صالح ، وداود بن عبد الله الجعفري) عن عبد العزيز بن محمد قال: حدثنا أسيد بن أبي أسيد، عن عبد الله بن أبي قتادة، عن أبيه ، بله.

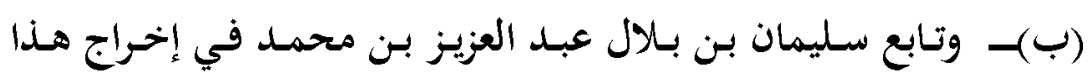

$$
\text { الوجه عن أسيد بن أبي أسيد. }
$$

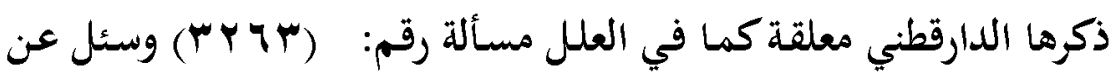

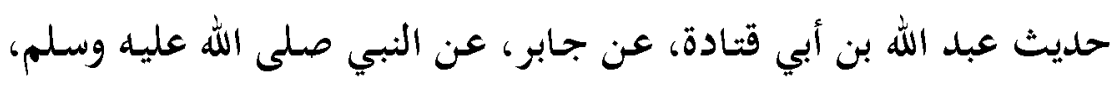
قال: من ترك الجمعة ثلاثا من غير عذر طبع على قلبه. فقال: يرويه أسيد بن أبي أسيد البراد، واختلف عند؛

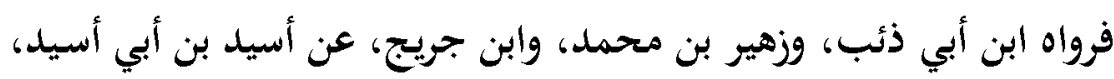
عن عبد الله بن أبي قتادة، عن جابر.

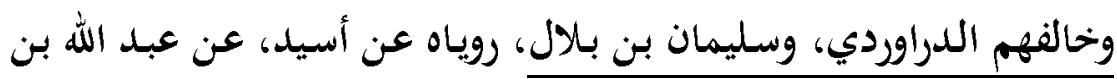
أبي قتادة، عن أبيا. والذي قبله أصح. دراسة إسناد الوجه الأول عند النسائي في السنن الصفرى كمـا في التحفة : أخبرنا عمرو بن سواد السرحي، المصري، قال: أخبرنا ابن وهـب قال: أخبرني ابن أبي ذئب، عن أسيد بن أبي أسيد، عن عبد الله بن أبي قتادة، عن جابر بن عبد الله ، بله. 


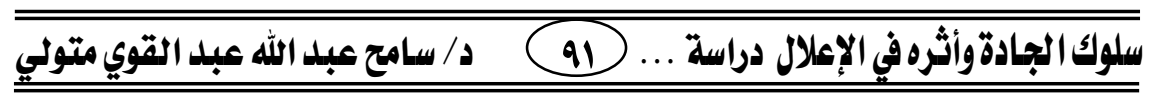

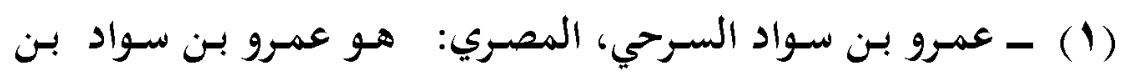

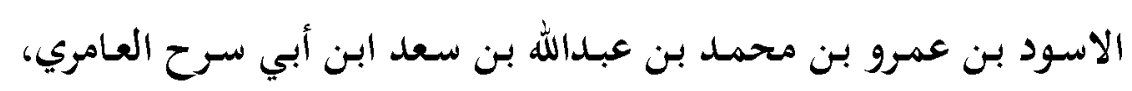
السرحي، أبو محمد المصري. روى عن : ابن وهب، والشافعي، وأشهب ،وغيرهم.

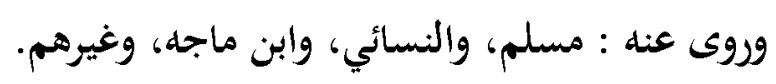

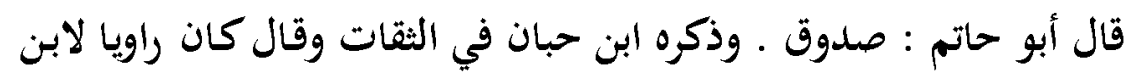
وهب ـ وقال الخطيب : كان ثقة. وقال مسلمة في الصلة: ثقة ـ ـوقال الحاكم : ثقة مأمون ـ وقال ابن حجر : ثقال : ثانة.

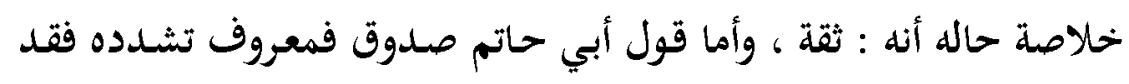
قال هذا في مسلم بن الحجاج، وعمرو بن علي الفلاس وهما من هما في والي هذا الشأن.

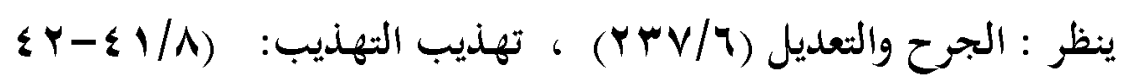

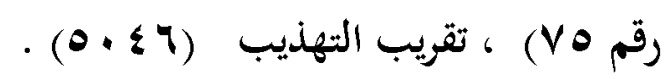

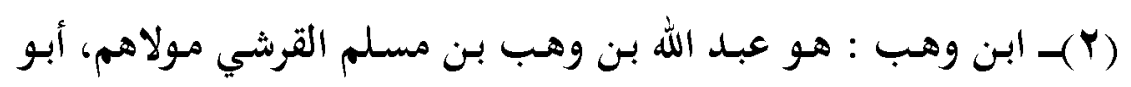
محمد المصري ،الفقيه. روى عن: هشام بن سعد ،والثوري، وابن عيينة، وغيرهم.

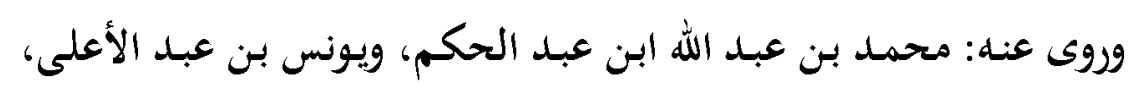
والربيع بن سليمان المرادي، وغيرهم.

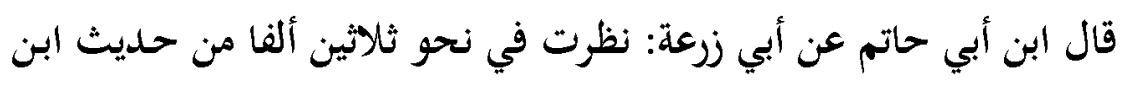

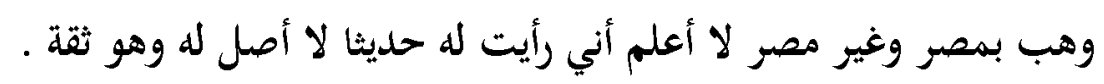




\section{مجلـة اللدرايـــة"ة}

وقال ابن سعد: عبد الله بن وهب كان كثير العلم ثقة فيما قال حدثنا وكان يدلس.

وقال العجلي: مصري ثقة صاحب سنة رجل صالح صاحب آثار. وقال الخليلي: ثقة متفق عليه وموطئه يزيد على كل من روى عن مالك. وقال ابن حجر: ثقة حافظ عابد . مات سنة خلاصـة حاله أنه: ثقة حافظ، عيبب عليه تساهله في التحمل، وأنه يرى المناولة والإجازة ،وهذا لا يقدح ؛لأنه ليست له مناكير فيما تحمل، وعيب عليه أيضا جمعه لألفاظ عدد من شيوخه في سياق واحد، قلت وهذا أيضا

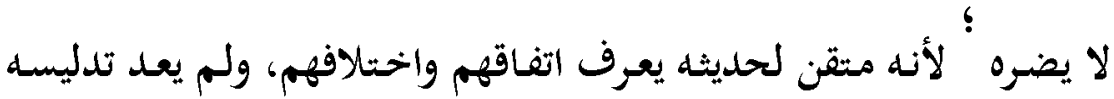
قادحا.

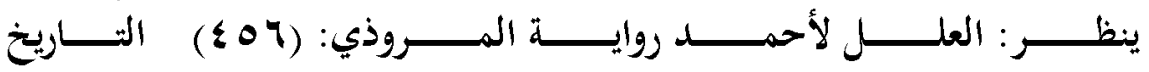

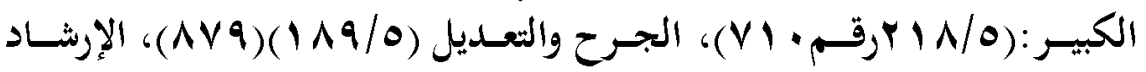

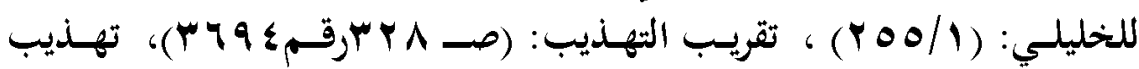

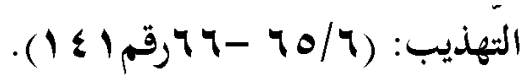

(T) - ابن أبي ذئب : هو محمد بن عبد الرحمن بن المغيرة بن الحارث بن أبي ذئب القرشي ،العامري، أبو الحارث المدني، ثقة فقيه فاضل كمـا قال الحافظ ابن حجر.

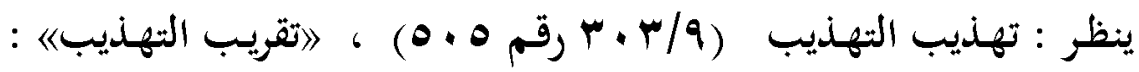




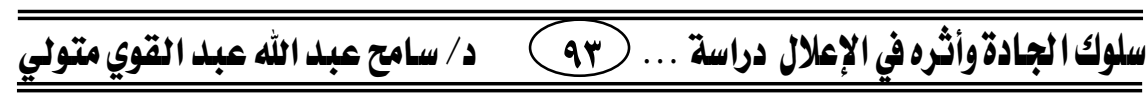

(§) - أسيد بن أبي أسيد : هو أسيد بن أبي أسيد يزيد البراد، أبو سعيد

المديني.

روى عن: أبيه ، وعبد الله بن أبي قتادة ، وغيرهما.

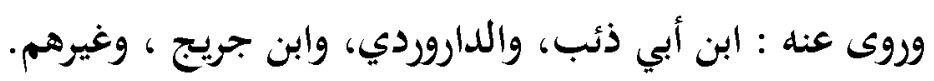

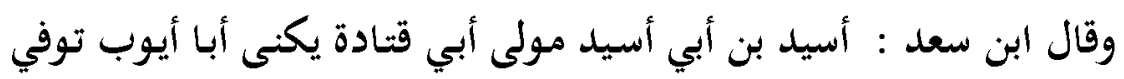

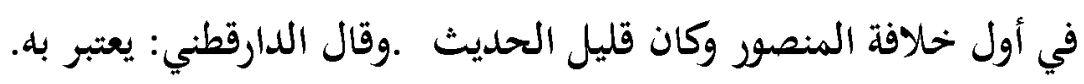
خلاصة حاله أنه : صدوق.

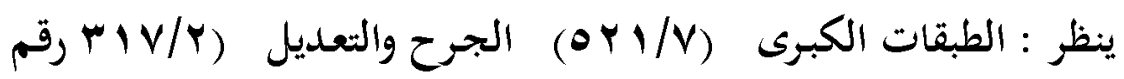

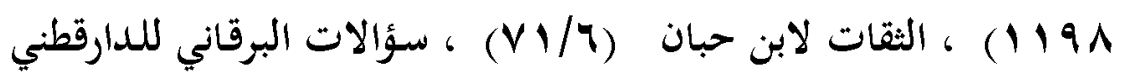

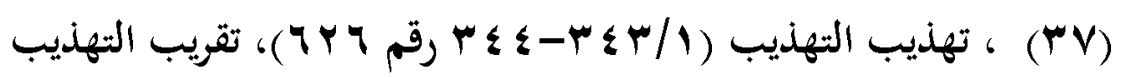

$$
\cdot(\bullet 1 \cdot)
$$

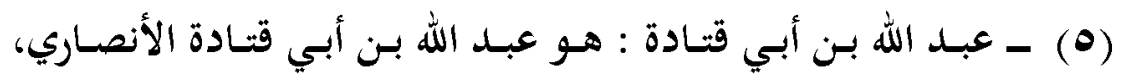

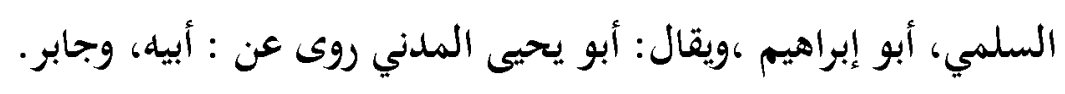

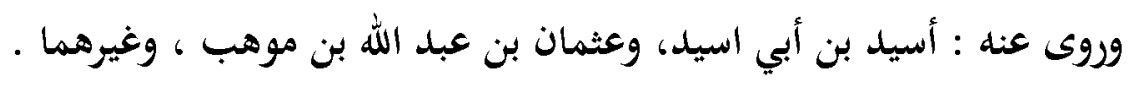

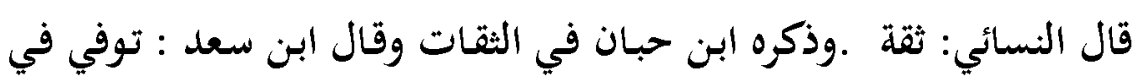

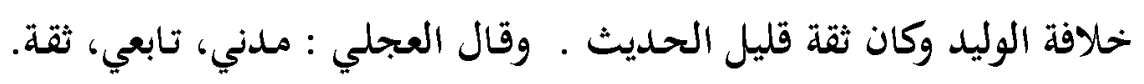
وقال ابن حجر: ثقة .

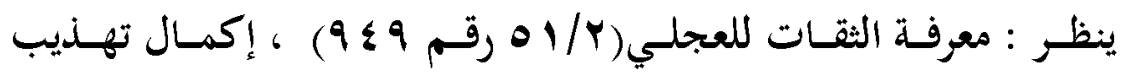

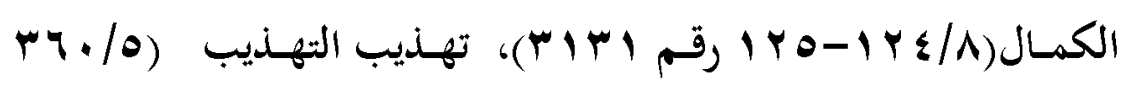

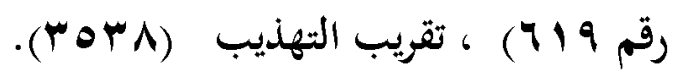




\section{مجلــة اللدرايــة}

(7) - جـابر بن عبـد الله : صحابي جليـل من صحابة رسـول الله ج .

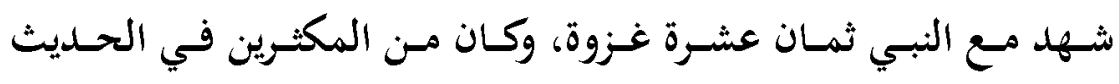

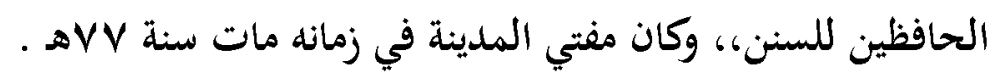

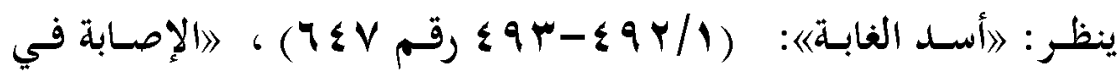

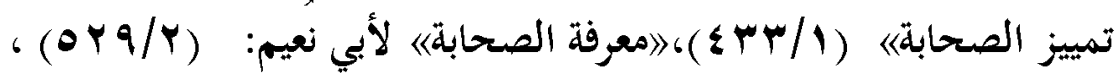

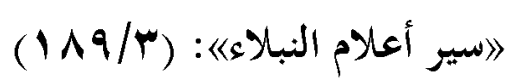

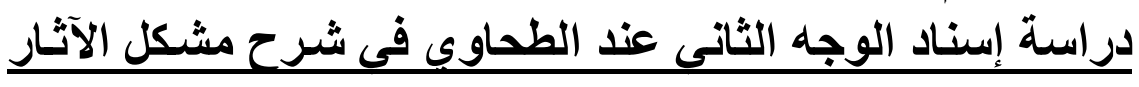

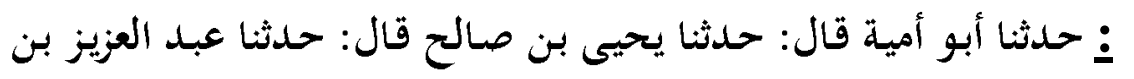
محمد قال: حدثنا أسيد بن أبي أسيد، عن عبد الله بن أبي قتادة، عن أبيه.

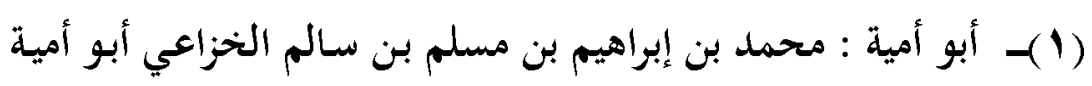

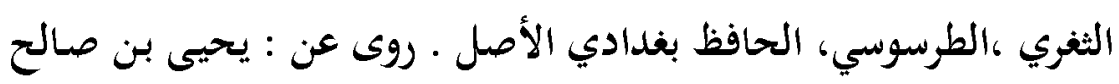

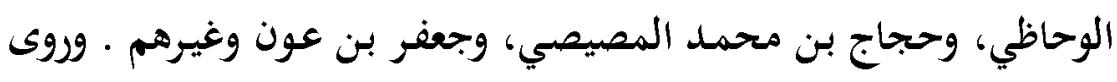

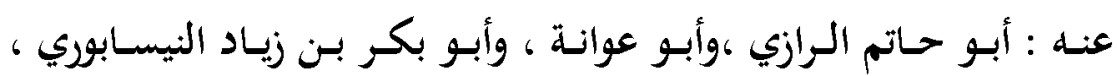

$$
\text { وغيرهم. }
$$

قال الآجري عن أبي داود : ثقة ـ وقال أبو بكر الخـلال: أبو أميـة رفيع

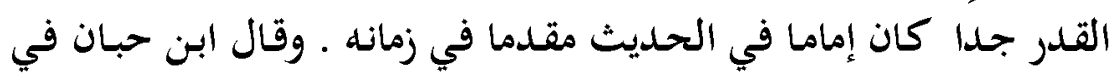
الثقات دخل مصر فحدثهم من حفظه من غير كتاب بأشياء أخطأ فيها فلا

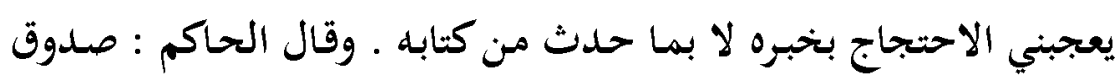

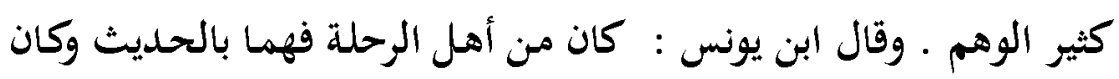
حسن الحديث . وقال ابن أبي حاتم : كتب إلى ببعض فوني : وائده وأدركته ولم

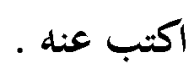
خلاصة حاله أنه : صدوق. 


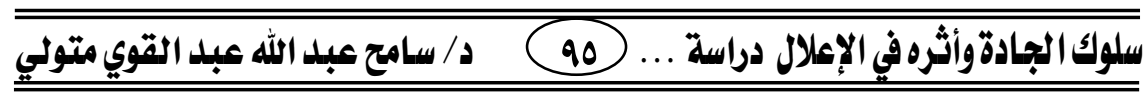

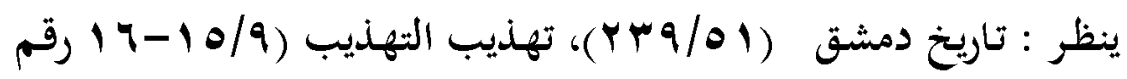

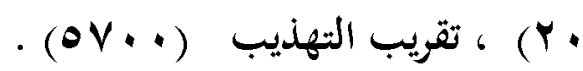

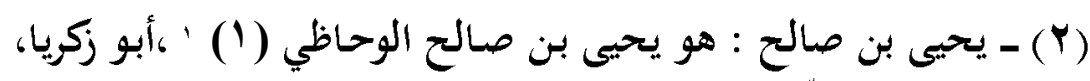

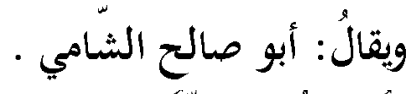

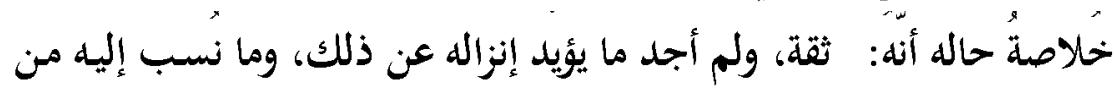
البدعة فلا تقدح فيه لعدم نسبته إلى الغلوُ فيها.

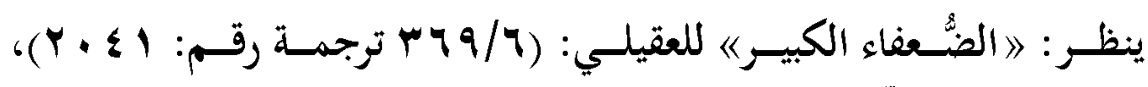

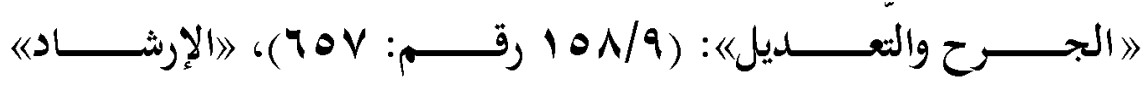

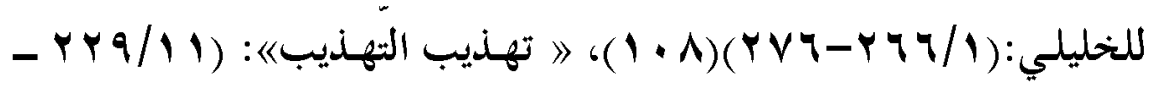

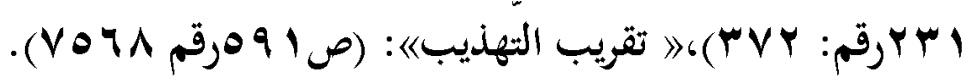

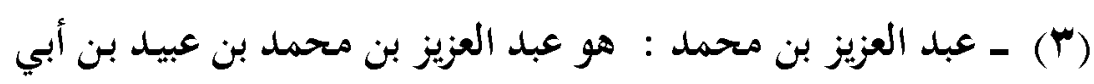

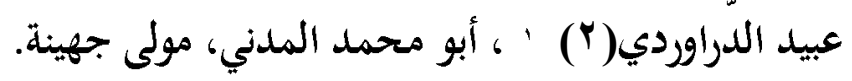

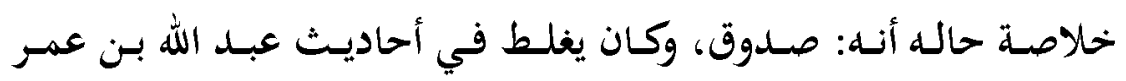

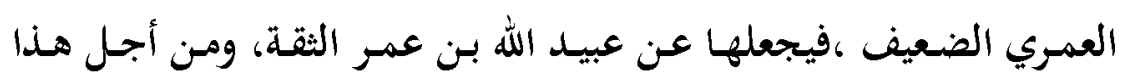
تكلّم فيه من تكلم.

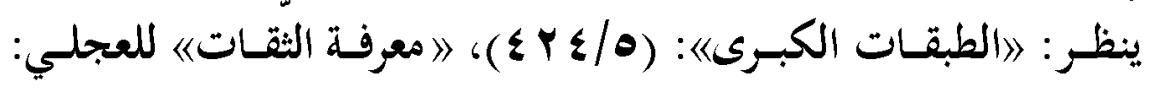

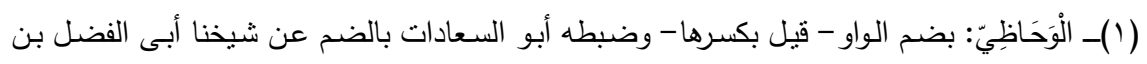

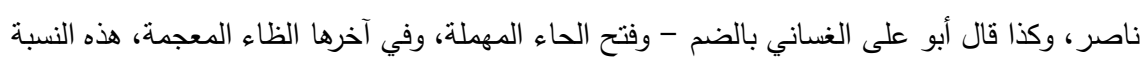

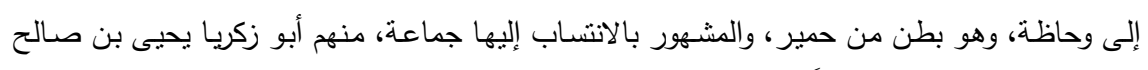

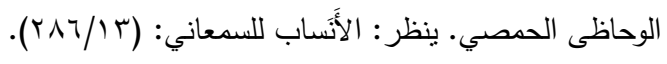

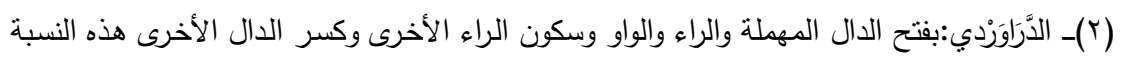

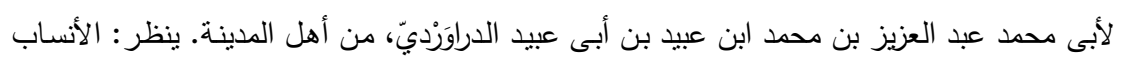




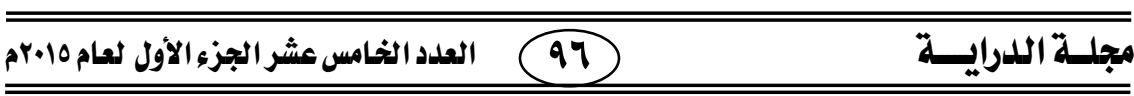

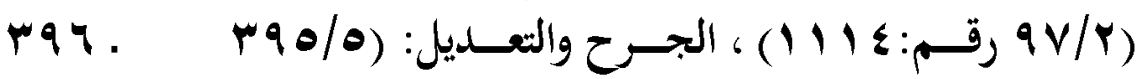

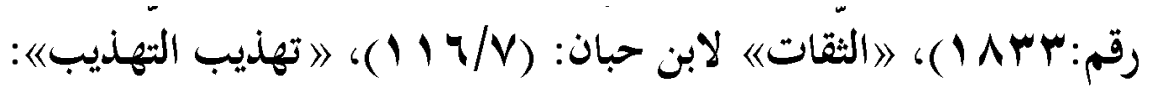

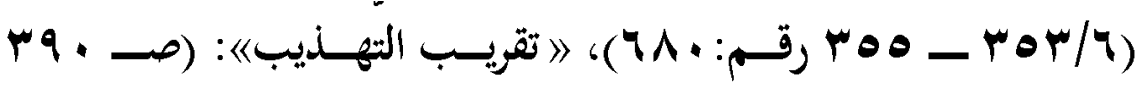

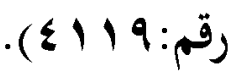

(ع) - أسيد بن أبي أسيد : صدوق ـ تقدمت ترجمتل في الوجه الأول.

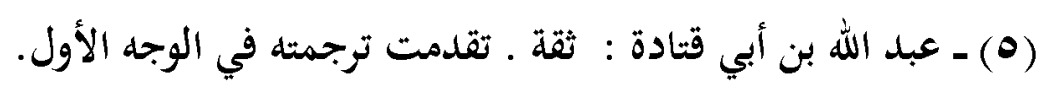

(7) - عـن أبيسه: هـو أبـو قتـادة الأنصـاري، السـلمي، فـارس رسـول الله ج اسـمه الحـارث بـن ربعـي، وقيـل: النعمـان، وقيـل: عمـرو، وقيل: عون، وقيل: مراوح، والمشهور الحارث بن ربعي. صحابي

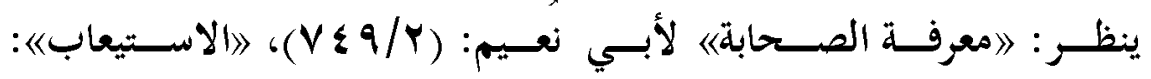

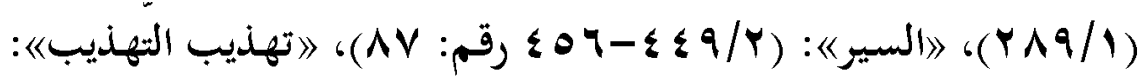

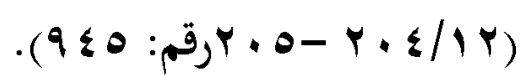




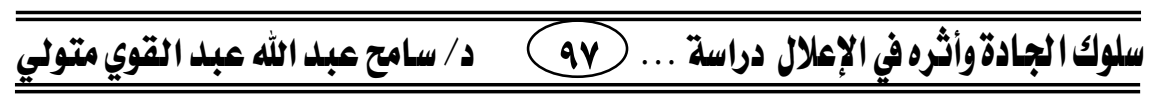

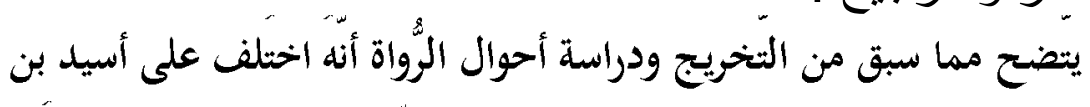

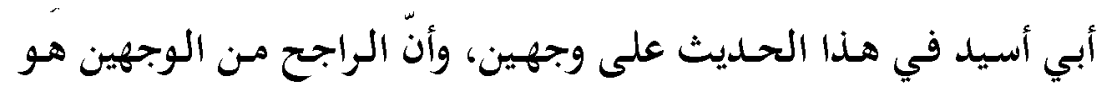

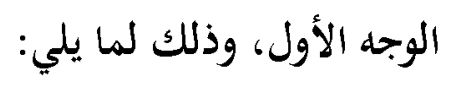

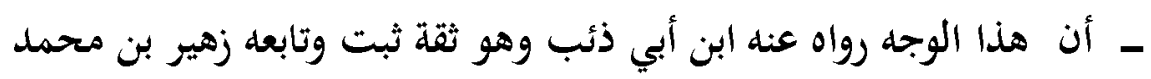

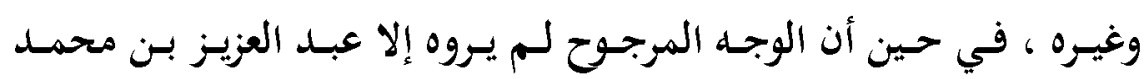

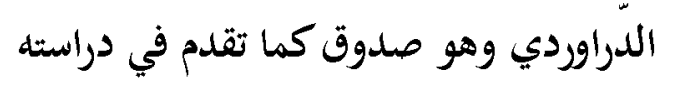

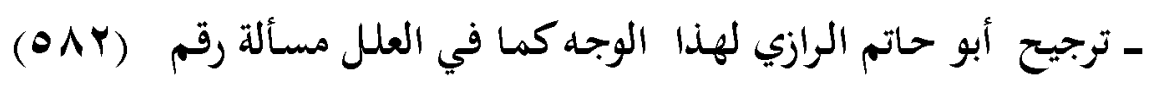

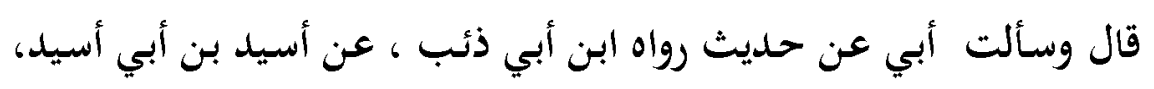

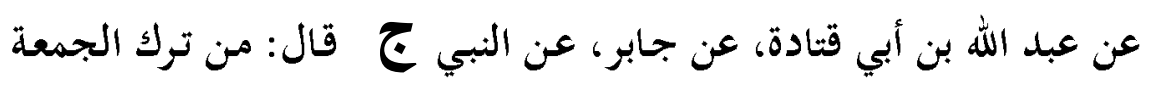

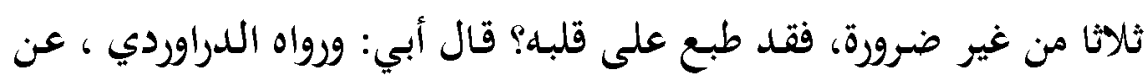

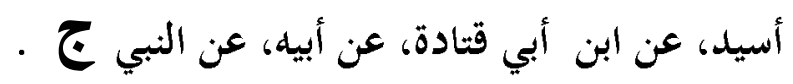

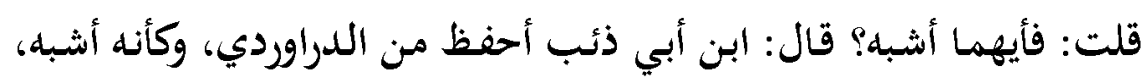

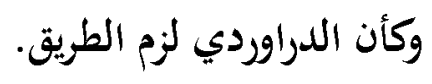

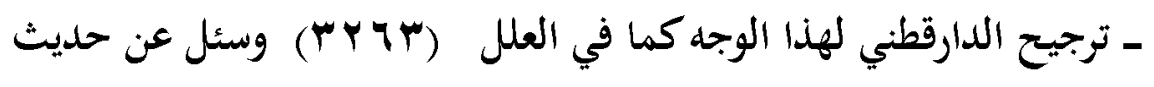

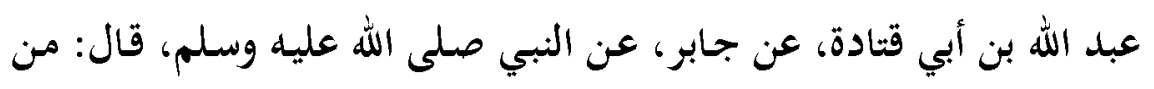

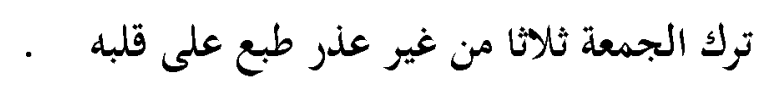

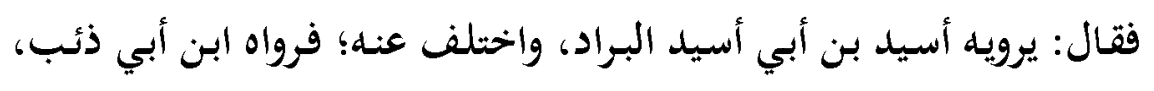

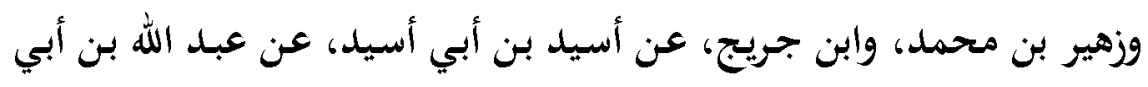
قتادة، عن جابر. وخالفهم الدراوردي، وسليمان بن بلال، روياه عن أسيد، عن عبد الله بن أبي

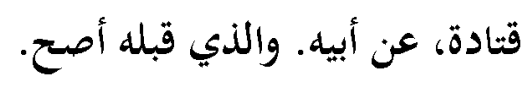




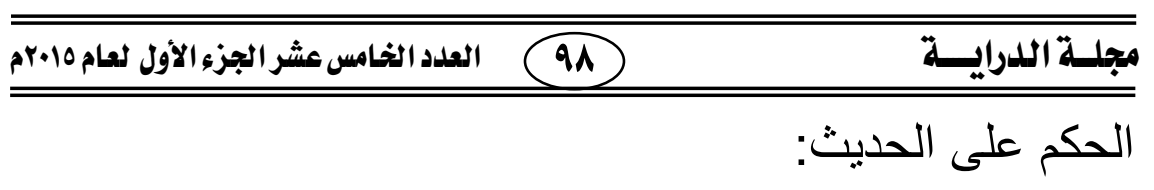

الحديث من وجها الراجح حسن ؛ لحال أسيد بن أبي أسيد كما تقدم في

$$
\text { دراسته. }
$$

\section{النظر في قرينة الاعلال وهى (سلوك الجادة) :}

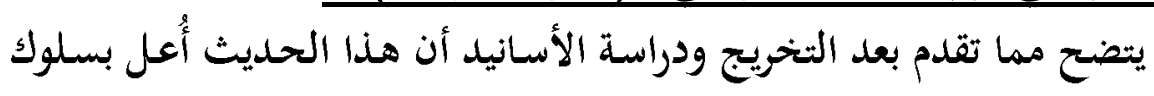
الجادة فأسيد، عن ابن أبي قتادة، عن أبيه جادة تسبق إليها الألسنة وأنها

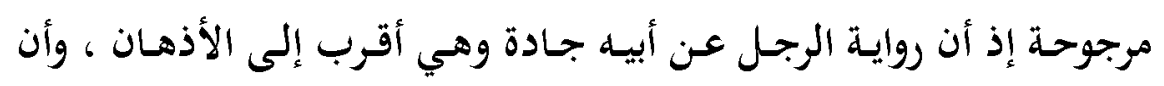

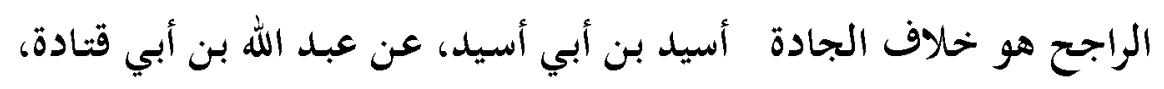

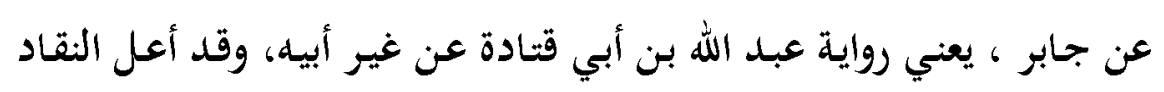
وعلى رأسهم أبو حاتم الرازي الحديث بهذه القرينة. 


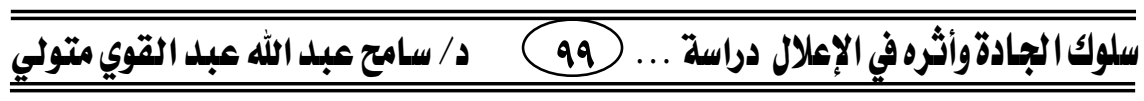

\section{المسألة الرابعة}

مسألة رقم (Y Y I I ) - وسألت أبي عن حديث رواه الحارث بن عبيد أبو

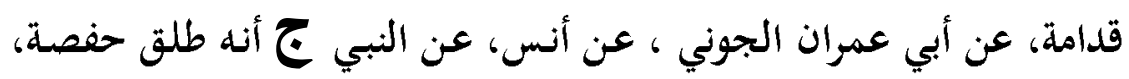

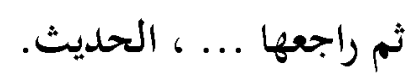

ورواه حماد بن سلمة، عن أبي عمران الجوني ، عن قيس بن زيد : أن النبي طلق حفصة بنت عمر رضى الله عنها تطليقة، ثم قال النبي ج ج : أتاني

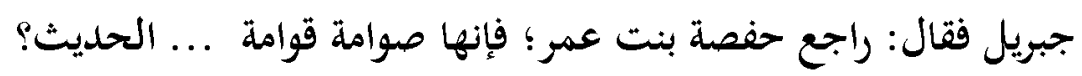
قال أبي: الصحيح حديث حماد، وأبو قدامة لزم الطريق. التخريج:

هذا الحديث يرويه أبو عمران الجوني واختلف عنه على وجهين:

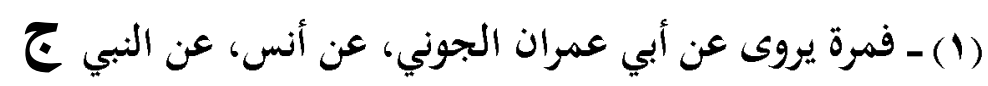

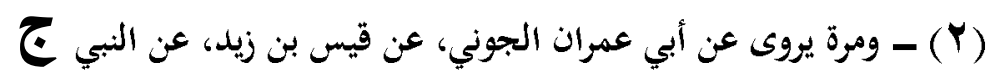

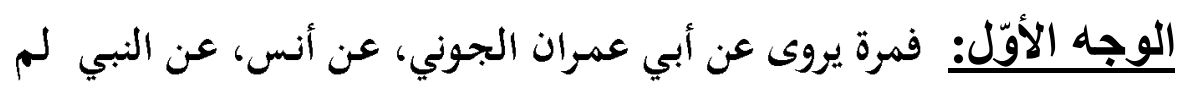

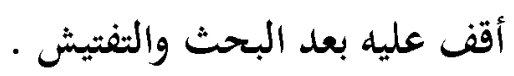
الوجه الثاني: ومرة يروى عن أبي عمران الجوني، عن قيس بن زيد، عن النبي

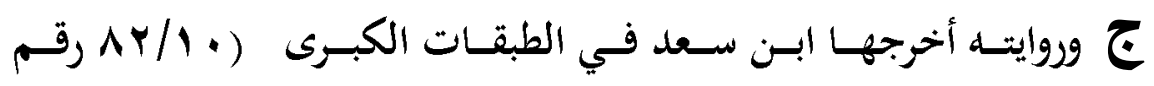

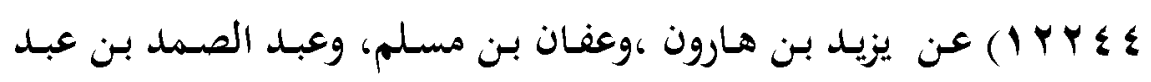

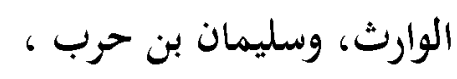

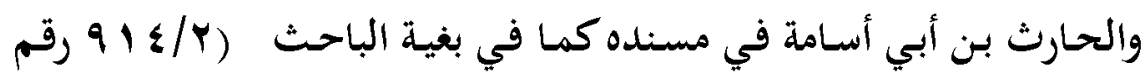

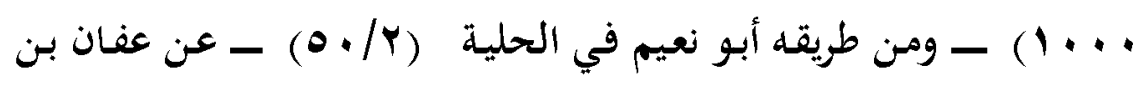




\section{مجلـة الدرايــة م}

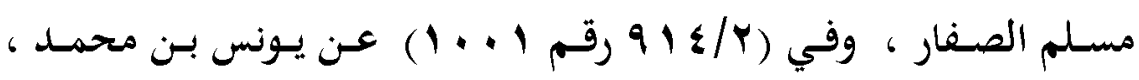
وأحال بمتنه على سابقه بقوله فذكر نحوه

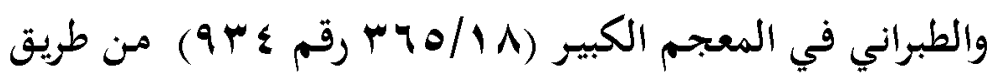

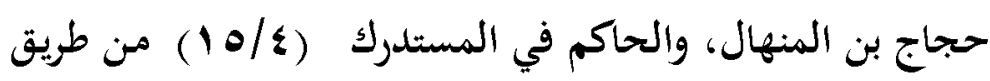

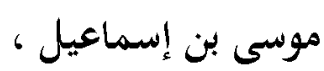

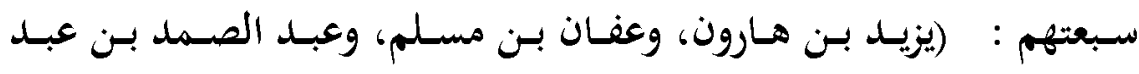

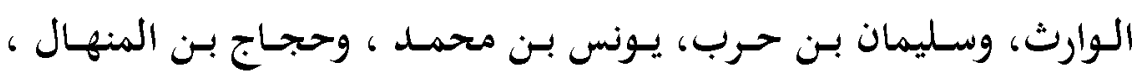

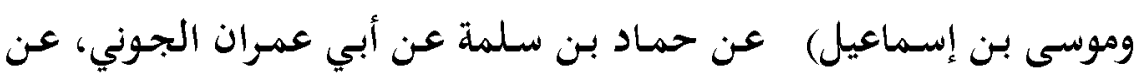

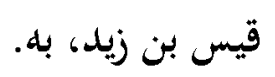

دراسة إسناد الوجه الأول عند ابن أبى حاتم ــ (معقلًا) وسألت أبي عن حديث رواه الحارث بن عبيد أبو قدامة، عن أبي عنمبران الجوني ، عن إن أنس، عن النبي ............

ــ الحارث بن عبيد أبو قدامة : هو الحارث بن عبيد أبو قدامة الإيادي(1)

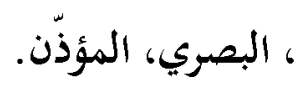

روى عن: أبي عمران الجوني، وسعيد الجريري، وعبـد العزيز بـن صهيب، وغيرهم. - موتم

وروى عنسه: ابن مهدي، وأبو داود الطّيالسي، وسعيد بن منصـور، وغيرهم. قال أحمد: مضطرب الحديث. وقال عمرو بن علي عن ابن مهدي: كان

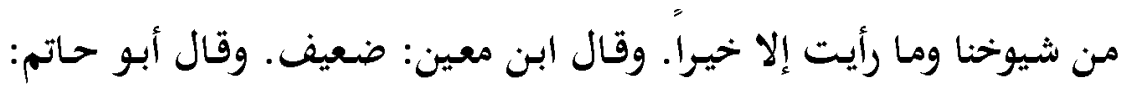




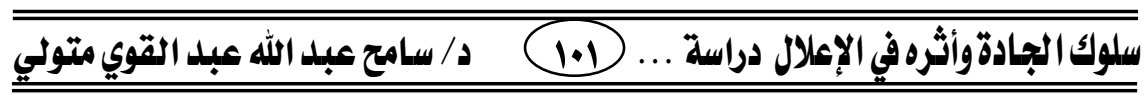

ليس بالقوي يكتب حديثه ولا يحتج به. وقال النسائي: ليس بذاك القوي.

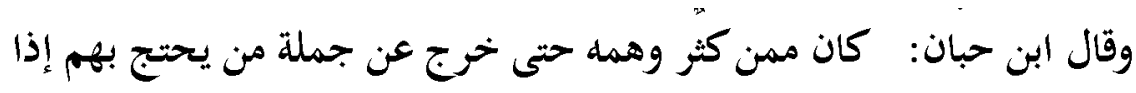

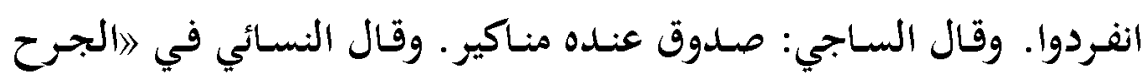

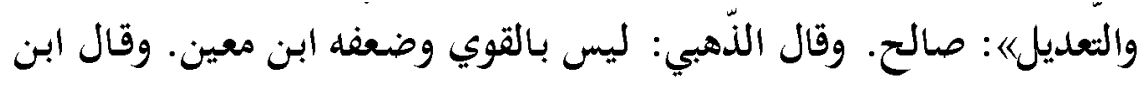
حجر: صدوق يخطئ. خلاصة حاله أنه: ضعيف يعتبر به، ولم أجد من حسن القول فيه سوى عبد الرحمن بن مهدي، وانتقى مسلم من حديثه ما توبع عليه.

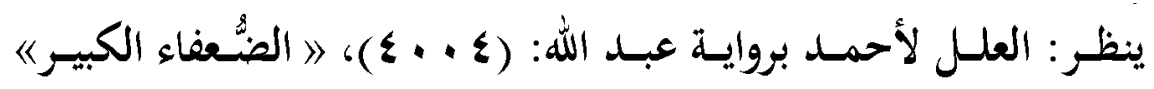

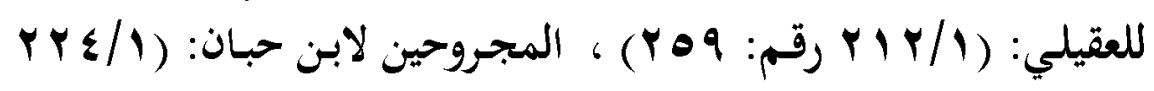

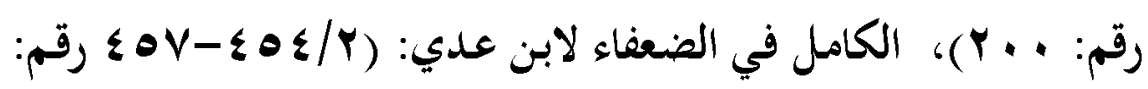
r

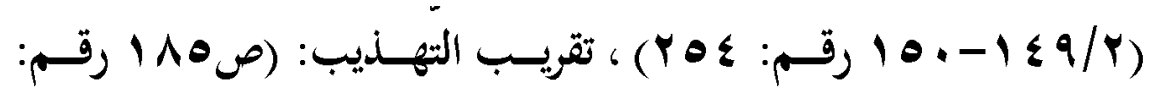

(1. T

ـ أبو عمران الجوني : هو عبد الملك بن حبيب الأزدي، ويقال : الكندي،

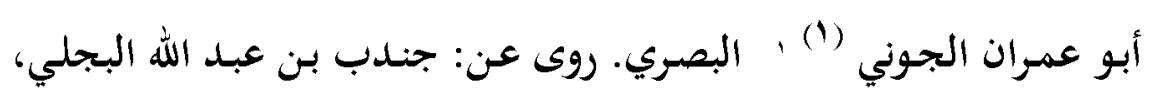
وأنس، وأبي فراس ربيعة بن كعب الأسلمي، وغيرهم.

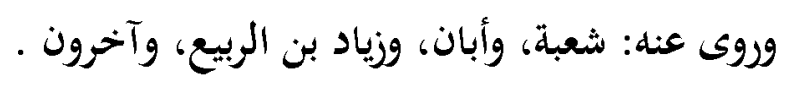




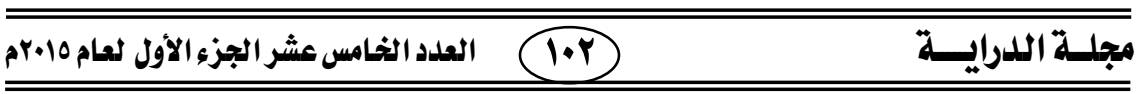

قال ابن معين: ثقة. وقال أبو حاتم: صالح. وقال النسائي: ليس بـ بأس. وذكره ابن حبان في الثقات. وقال ابن سعد: كان ثقة وله أحاديث. وقال

الذّهبي، وابن حجر : ثقة. خلاصة حاله أنه: ثقة.

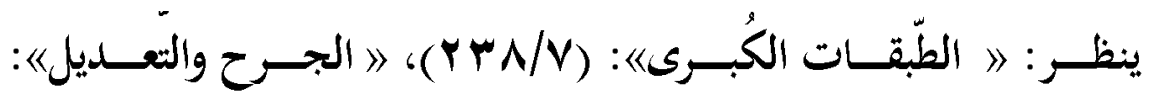

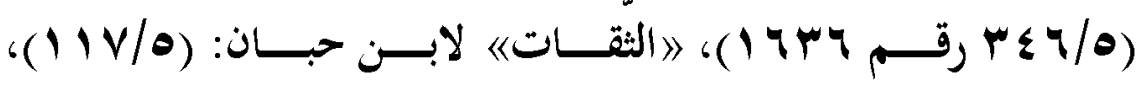

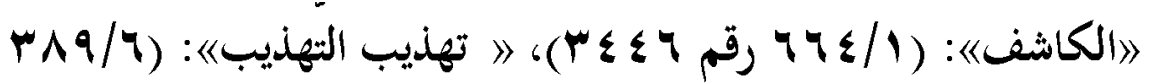

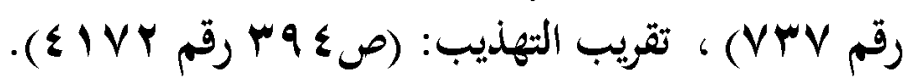

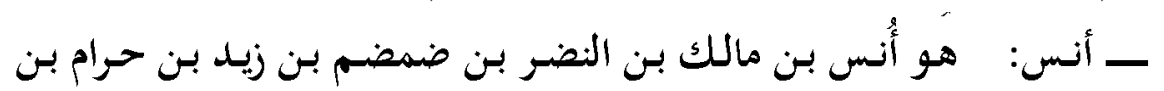

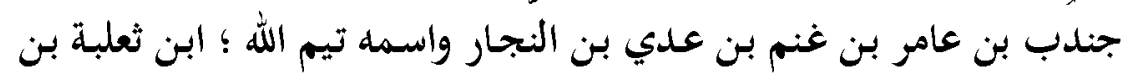

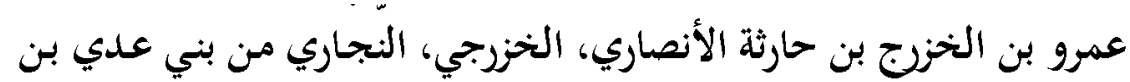

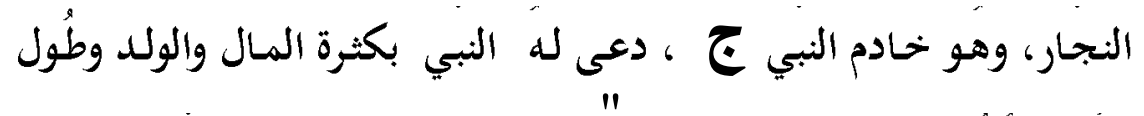

العمر ودخول الجنة وذلك عندما جاءت بـه أم سليم إلى النبي ج وأنـا

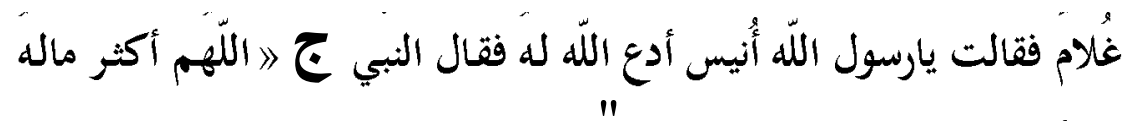
وولدهُ وبارك له فيما أعطيتهه|(') ' . قال أنس بن مالك : فقد رأيت اثنتين

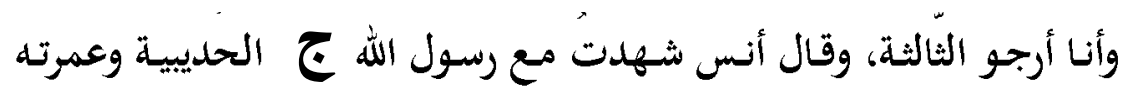
والحج والفتح وحنيناً والطّائف، مات سنة اثنتين وقيل ثلاث وتسعين، وقد جاوز المائة . 


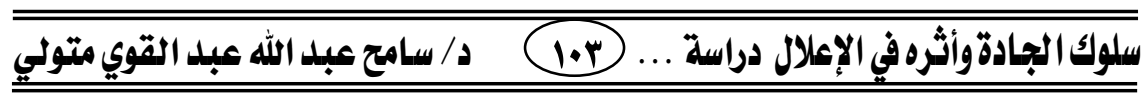

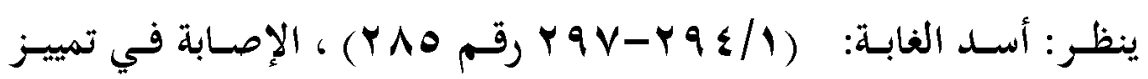

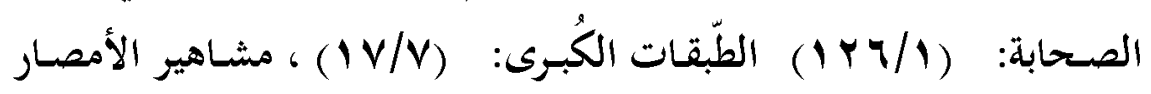

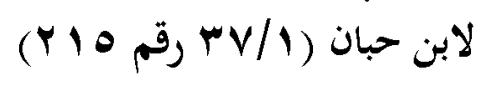

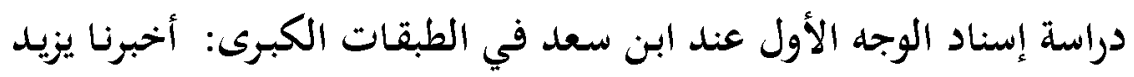

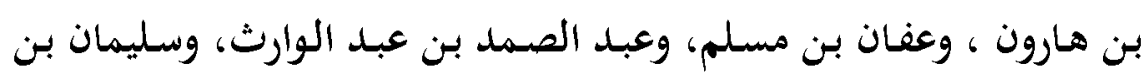

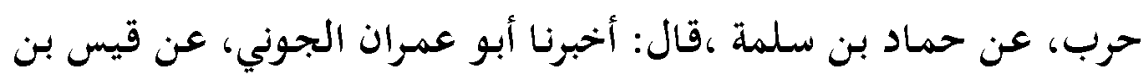
زيد، أن رسول الله صلى الله عليه وسلم

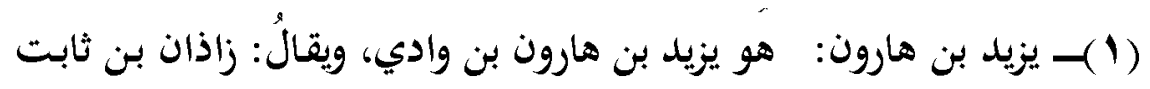
السُّلمي مولاهم، أبو خالد الواسطي.

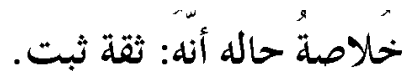

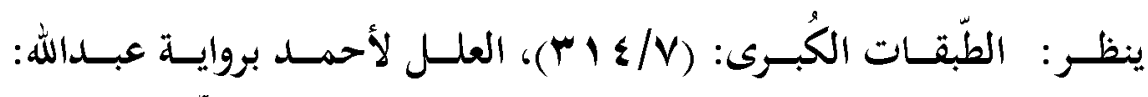

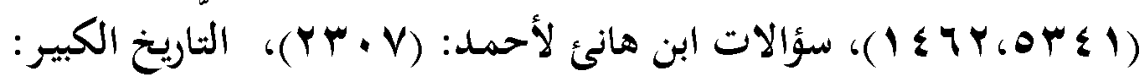

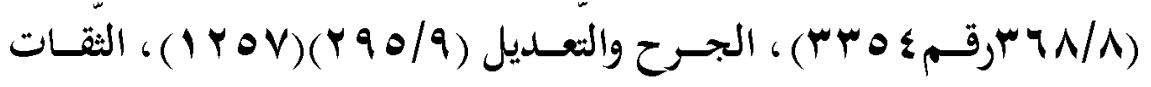

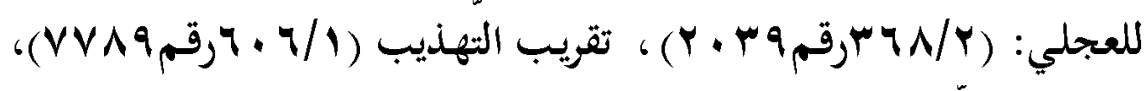

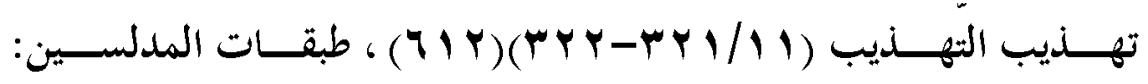
. $(r T)(Y V / 1)$

ـ و وعفان بن مسلم : هو عفّان بن مسلم بن عبد الله الباهلي، أبو عثمان

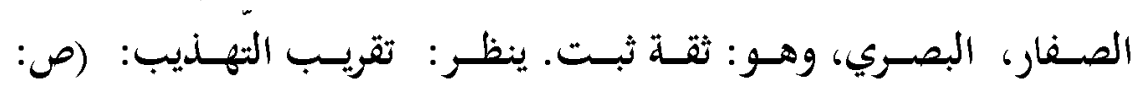




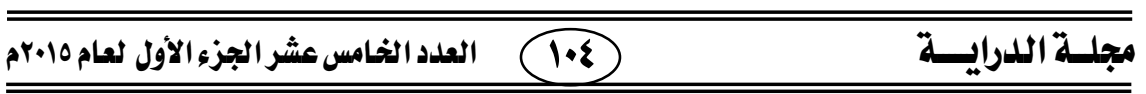

ـ وعبد الصمد بن عبد الوارث: هو عبد الصمد بن عبد الوارث التميمي،

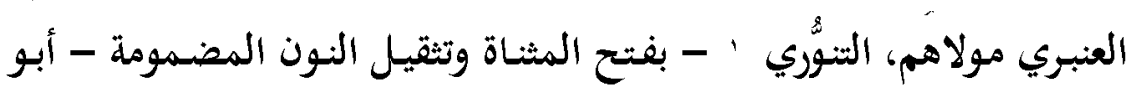
سهل البصري.

روى عـن: أبيسه، وعبـد الله بـن أبسي يزيسـ، وغيرهمــا. وروى عنسه: ابنسه عبــ

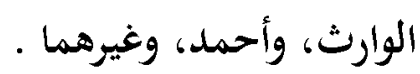
قال ابن أبي حساتم: صددوق صـالح الحديث. و وذكرهُ ابن حبان في الثّات.

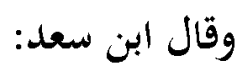
كان ثقة إن شاء الله.وقال الحاكم: ثقة مأمون. وقال ابن قانع: ثقة يخطيء ، ونقل ابن خلفون توثيقه عن ابن نمير. وقال

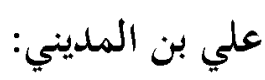
عبد الصمد ثبت في شعبة. وقال ابن حجر : صدوق ثبت في شعبة . خلاصة حاله أنه: ثقة على قول الأكثرين .

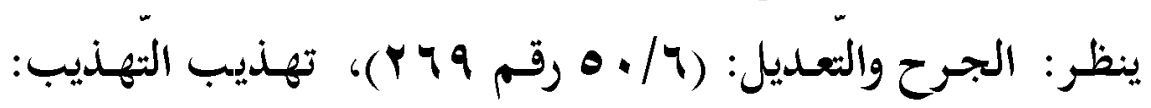

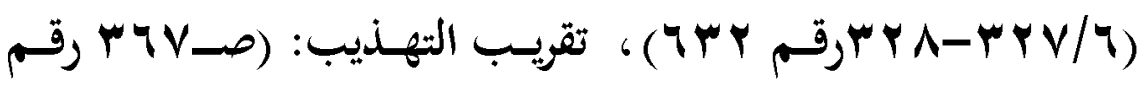
$(\varepsilon \cdot \Lambda$ • وسليمان بن حرب: هو سليمان بن حرب: هو سليمان بن حرب بن

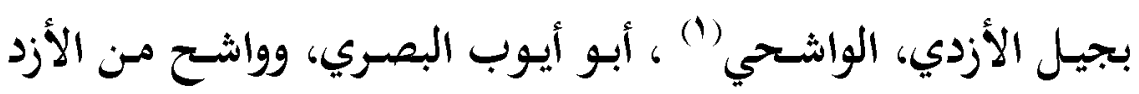
سكن مكة، وكان قاضيها. 


\section{سلوك الجادةروأثره في الإعلال دراسة ... (1.0) م د/ سامع عبد اللأه عبل القوي متولي}

روى عن: شعبة، والحمادين، وغيرهم. وروى عنه: البخاري، وأبو داود، وغيرهما.

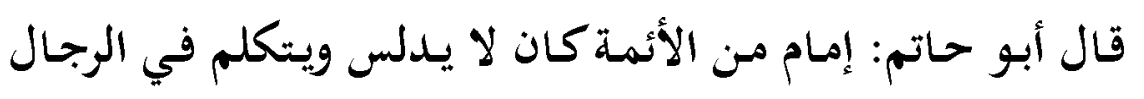

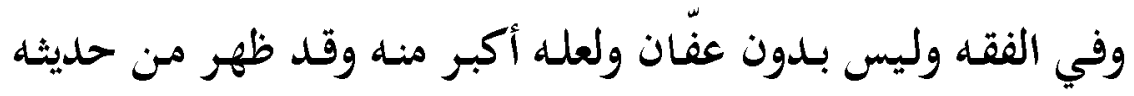

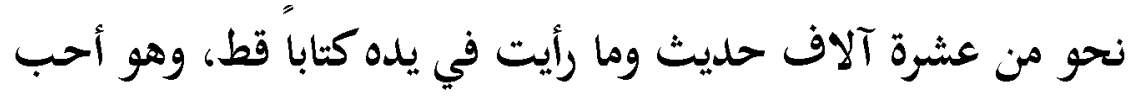

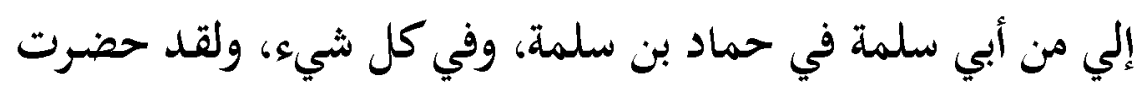

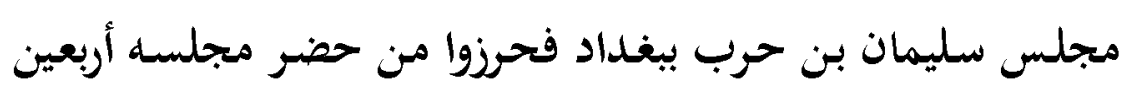

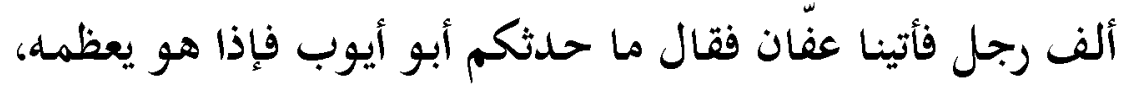

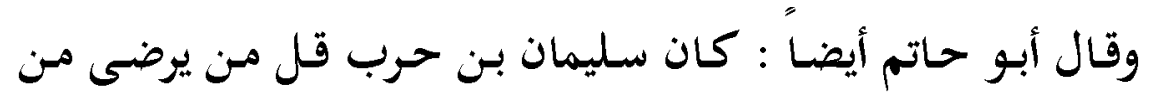

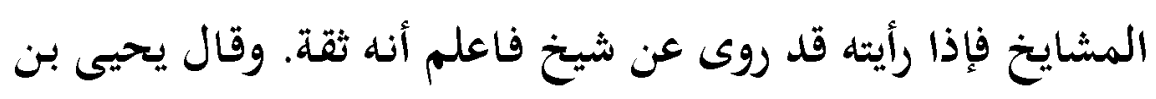
أكثم قال لي المأمون من تركت بالبصرة فوصفت له له مثايخ منهم سليمان بـن حرب وقلت هو ثقة حافظ للحـديث عاقل في نهايـة الستر والصيانة فأمني بحمله إليه فكتبت إليه في ذلك فئل فقدم وولان قضاء مكة فخرج إليها.

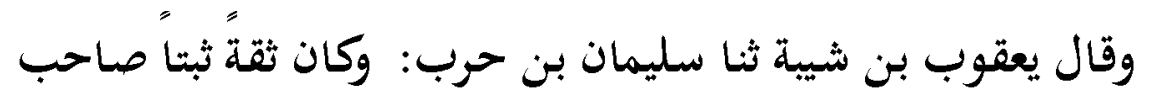
حفظ. وقال النسائي: ثقة مأمون. وقال ابن خراش: كان ثقةً. وقال ابن

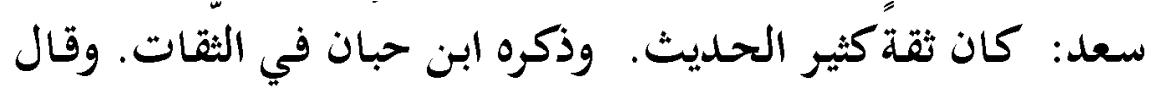

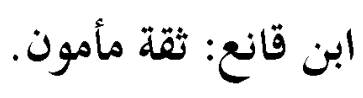




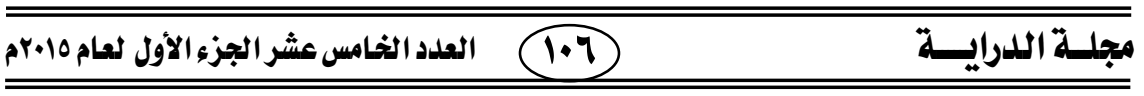

وقال ابن حجر: ثقة إمام حافظ. ومات سنة (s Y \&A). خلاصة حاله أنه: ثقة حافظ.

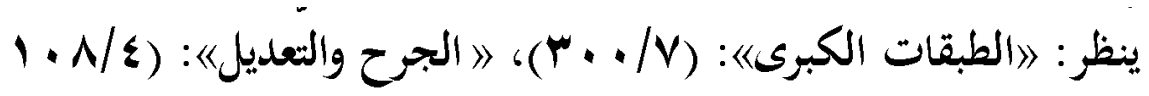

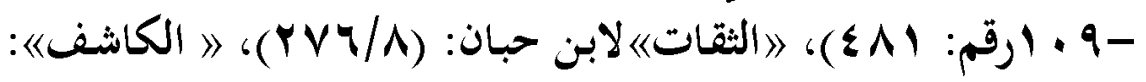

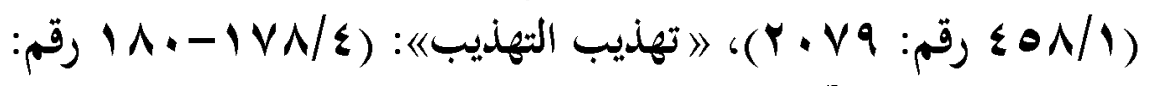

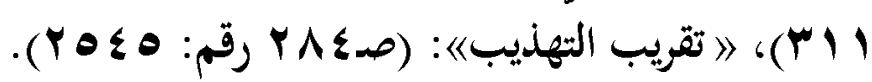

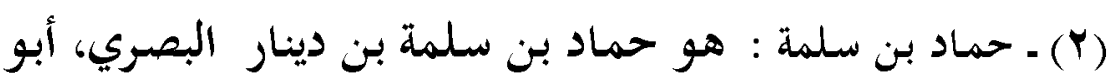
سلمة مولى تميم، ويقال: مولى قيش، وقيل: غير ذلك. روى عن: ثابت البناني، وقتادة، وخاله حميد الطويل، وخلقّ كثير .

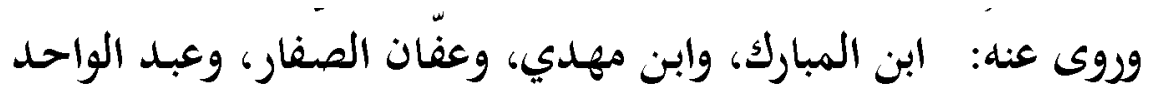
بن غياث، وغيرهم. قال ابن المبـارك: دخلـت البصـرة فما رأيـت أحسدا أثـبه بمسـالك

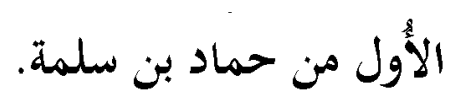

وقال ابن مهدي: لو قيل لحماد بن سلمة إنك تموت غداً ما قدر أن يزيد في العمل شيئا. وقال ابن المديني: لم يكن في أصسحاب ثابت أثبت من حماد ابن سلمة، وقال الإمام أحمد أثبتهم في ثابت حماد بـ سلمةة، وقال ابن معين : من خالف حماد بن سلمة في ثابت فالقول قول حماد ؛ ولذا فِإن مسلماً لم يخرج في في صحيحه لحماد بن سلمة في الأصول إلا من روايته عن ثابت، وخرج له في 


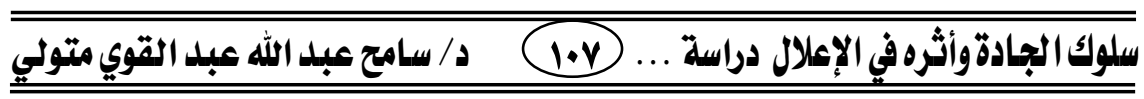

الشواهد والمتابعات عن طائفة.

وقال الإمام أحمد في مرة حماد بن سلمة أثبت الناس في حميد الطويل، سمع منه قديما. ورواية عفان بن مسلم عنده قد أند أنى عليها

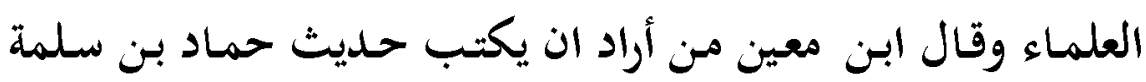

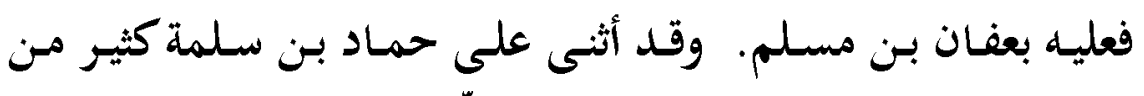
العلماء فوثقه الإمام أحمد وابن معين والنسائي. وقال العجلي: ثقة رجـل صالح حسن الحسديث. وقال ابن سعد:

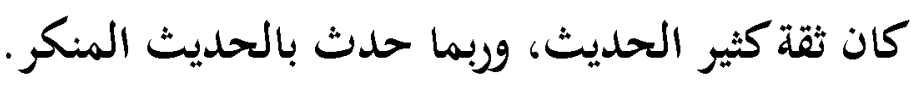

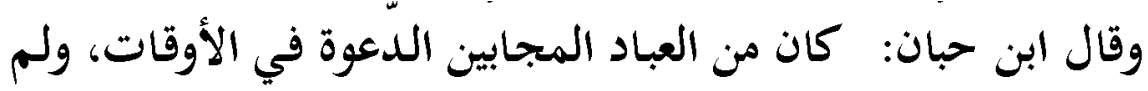

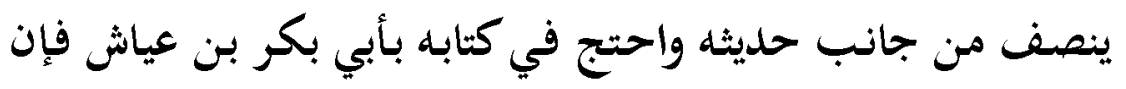

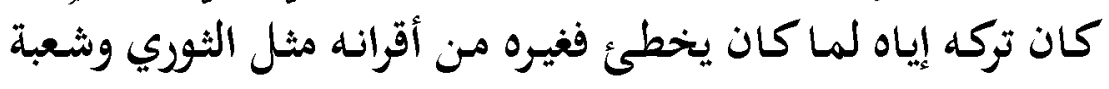

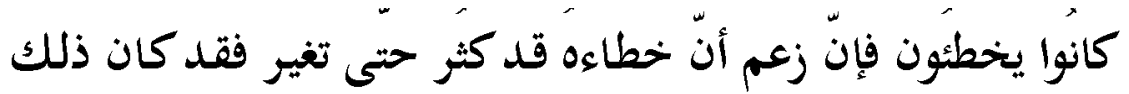
في أبى بـ كر بن عياش موجوداً، ولم يكُن من أقران حماد بن فئ سلمةً

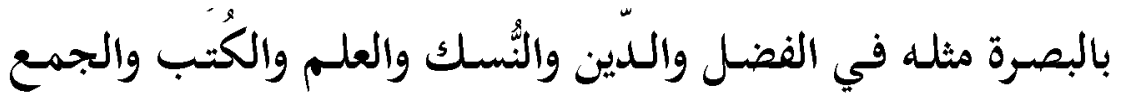

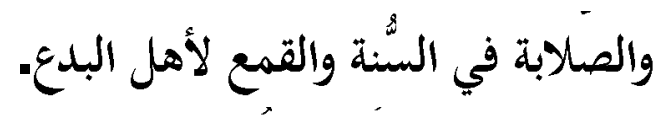

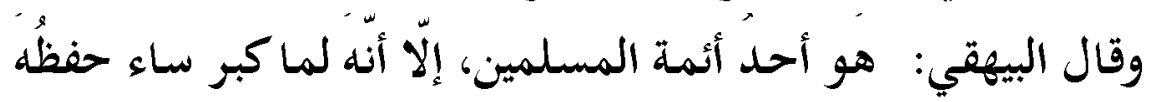

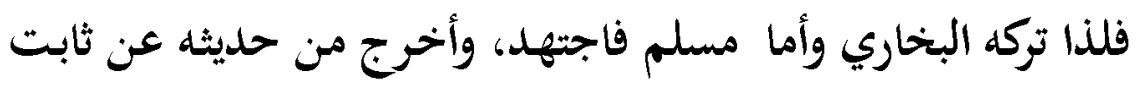

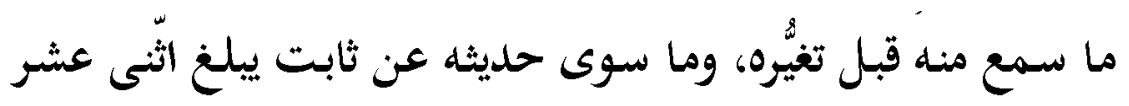
حديثا أخرجها في الثّواهد. 


\section{مجلـة اللدرايـــة ة}

وقـال الحـافظ ابـن حجـر: ثقـه عابـد أثبـت النـاس في ثابـت وتغيـر حفظه بأخرة. مات سنة (7V) 17 هـ).

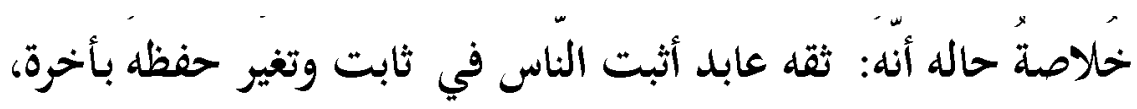
لكن ما كان من روايته عن ثابت أو خاله حميد الطّيل، أو من رواية عفّان بن مسلم عنه فهى صحيحة.

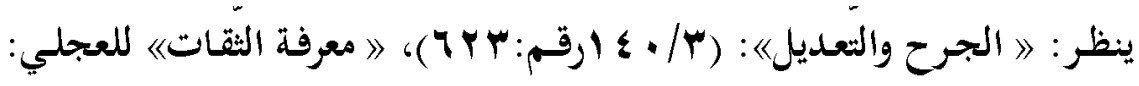

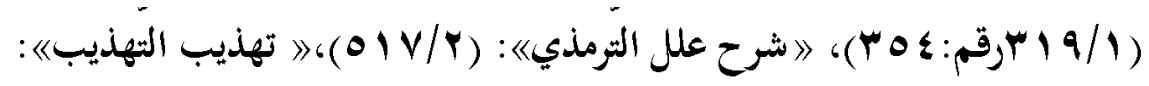

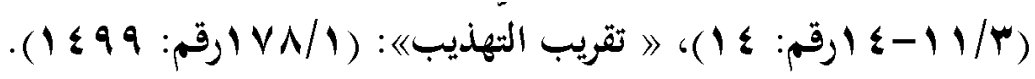

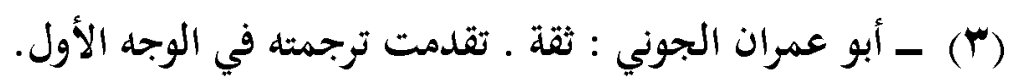

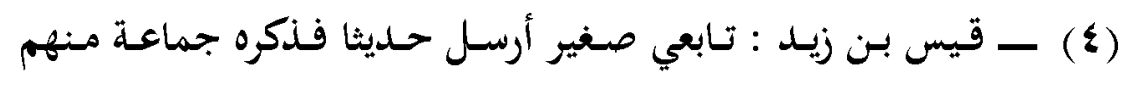
الحارث بن أبي أسامة في الصحابة. وذكره ابن أبي حاتم وغيره في التابعين تبعا للبخاري.

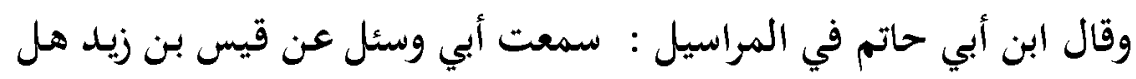
له صحبة قال لا وقال الحافظ ابن حجر : مختلف في صحبته.

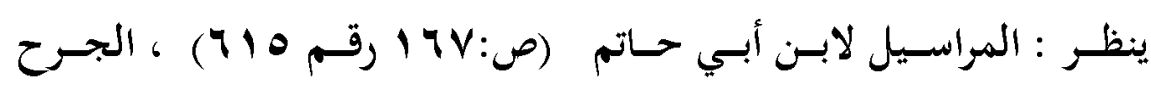

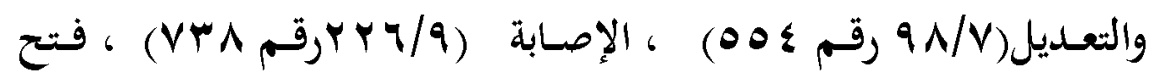

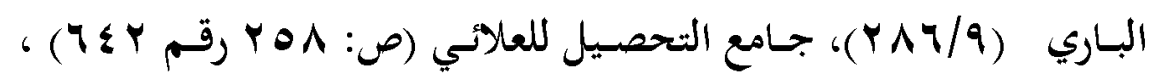

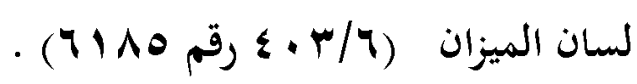




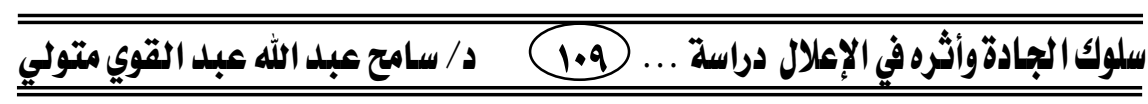

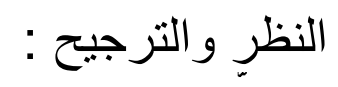

يتضح مما سبق من التّخريج ودراسة أحوال الرُواة أنهُ اختلف عن أبي عمران

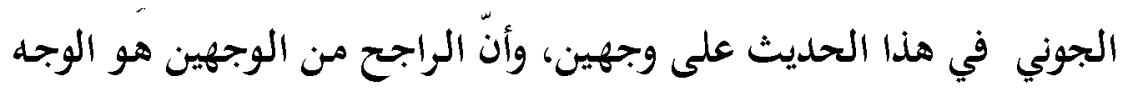

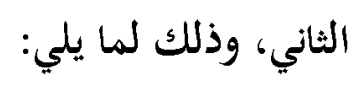

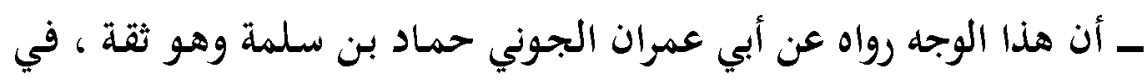

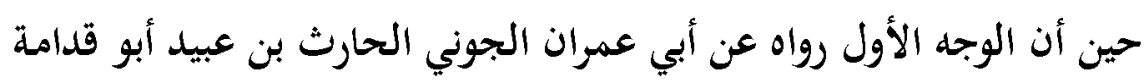

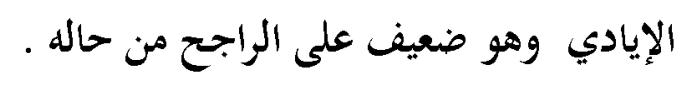

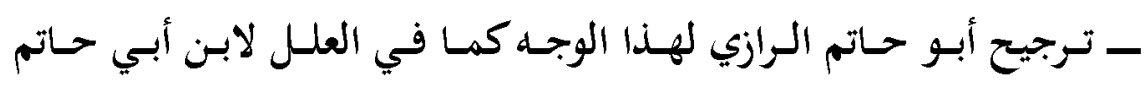

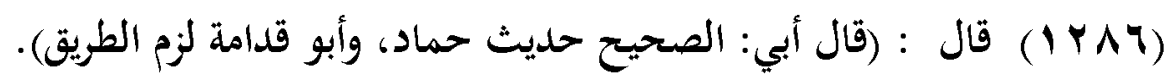

$$
\text { الحكم على الحديث: }
$$

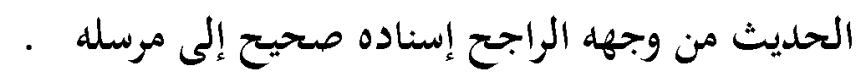

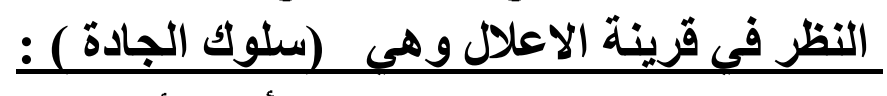

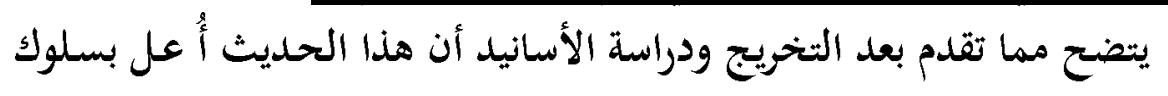

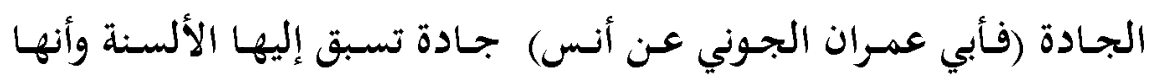

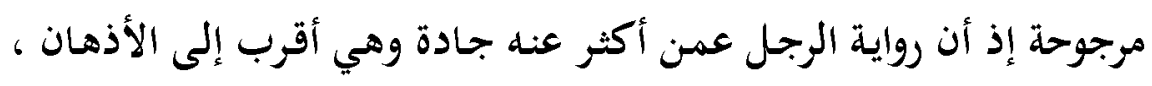

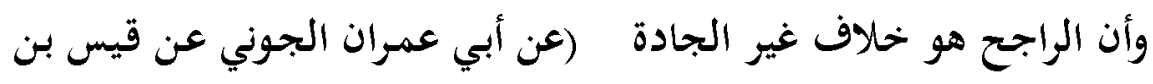
زيد) ، وقد أعل النقاد وعلى رأسهم أبو حاتم الرازي الحديث بهذه الجهاد القرينة. 


\section{مجلـة اللدرايــة م}

\section{المسألة الخامسة}

مسألة رقم (r Y I I - وسألت أبي عن حديث رواه زكريا بن منظور ؛ قال: حدثني أبو حازم ، عن سهل بن سعد ؛ قال: مر رسول الله ج بـدي الحليفة، فإذا مو بشـاة ميتة، فقال النبي ج : للدنيا أهون على الله من هذه على أهلها؟ قال أبي: هذا خطأ؛ رواه يعقوب الإسكندراني (1) ، عن أبي حازم، عن عبد الله بن بولا ، عن رجل من المهاجرين، عن النبي ج ، وهذا أشبه، وزكريا لزم الطريق. قلت: ما حال زكريا هذا؟ قال: ليس بقوي.

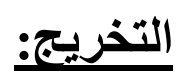
هذا الحديث يرويه أبو حازم واختلف عنه على وجهين:

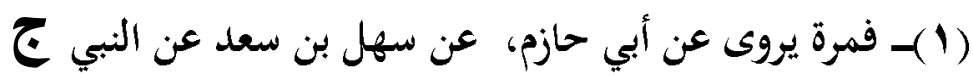

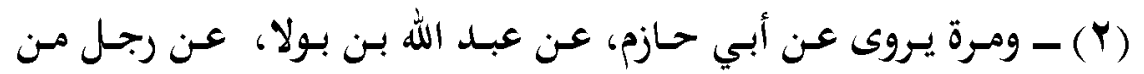

$$
\text { الوجهاجرين، عن النبي }
$$

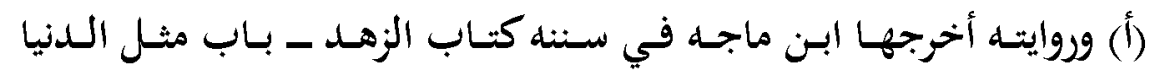

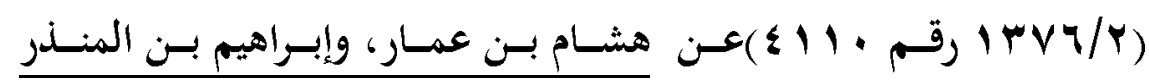
الحزامي، ومحمد بن الصباح،

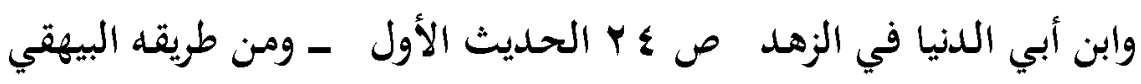

$$
\text { في شعب الإيمان }
$$




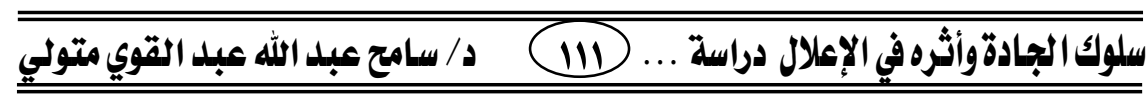

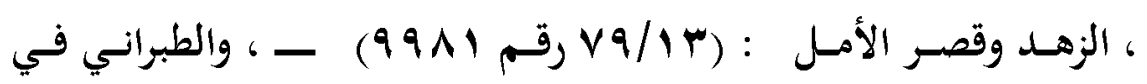

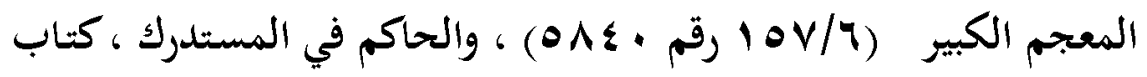

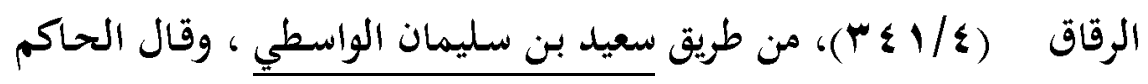
: هذا حديث صحيح الإسناد ولم يخرجاه.

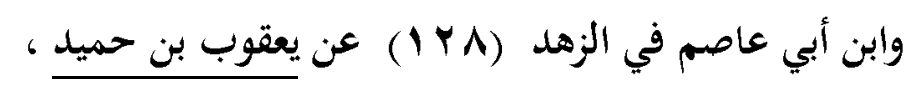

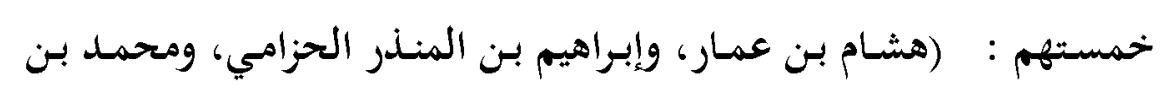

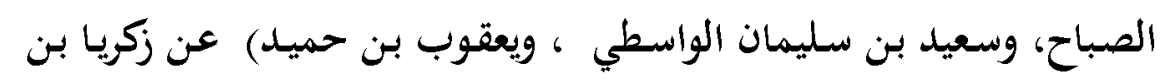

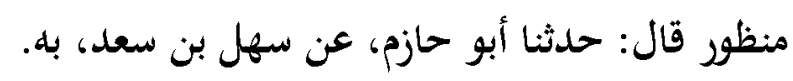

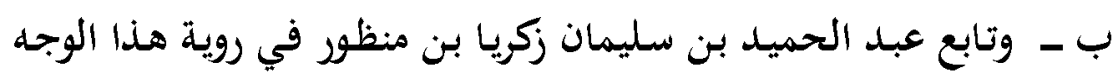

$$
\text { عن أبي حازم. }
$$

وروايته أخرجها الترمذي في الجامع ، أبواب الزهد ــ باب ما جاء في هوان

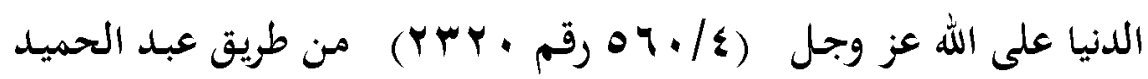
بن سليمان، عن أبي حازم ،عن سهل بن سعد ، بهله

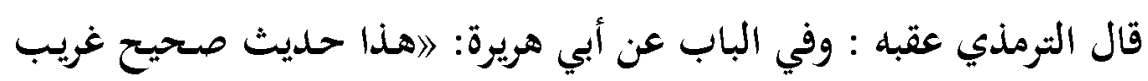
من هذا الوجهلها ج - وتابع عبد الله بن مصعب زكريا بن منظور ، وعبد الحميد بن سليمان في روية هذا الوجه عن أبي حازم

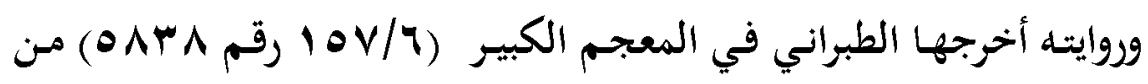

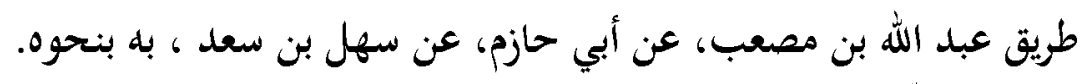

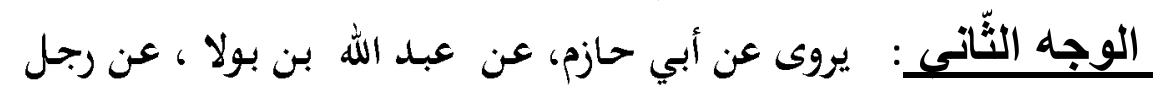

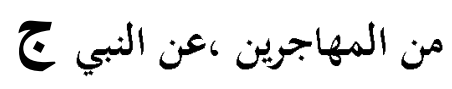




\section{مجلـة اللدرايـــة"ة}

- وروايته أخرجها ابن أبي الدنيا في 》ذم الدنيا《 ( إه) - ومن طريقه

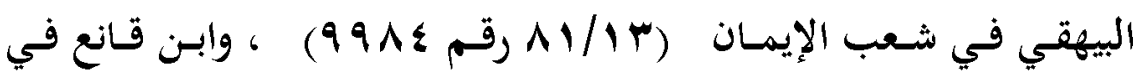
معجم الصحابة (1/ ـ 1) ـ من طريق عبد العزيز بن أبي حازم ، حـدثني أبي عن عبد الله بولا، عن أبيه من أصحاب النبي صلى الله عليه وسلم ، بـ اله بنحوه.

دراسة إسناد الوجه الأول عند ابن ماجه في سننه : عن هشـام بن عمـار،

$$
\text { وإبراهيم بن }
$$

المنذر الحزامي، ومحمد بن الصباح، قالوا: حدثنا أبو يحيى زكريا بن منظور قال: حدثنا أبو حازم، عن سهل بن سعد........

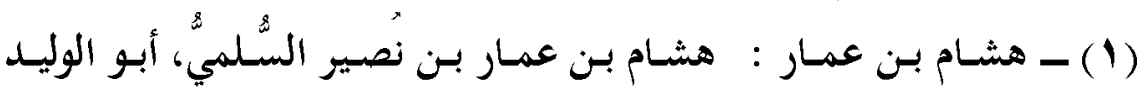

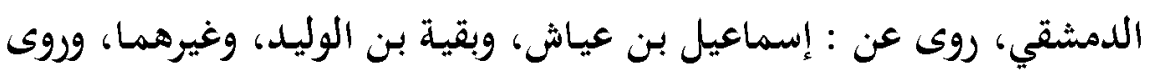
عنه: البخاري، والقاسم بن سلام ،وغيرهما. قال عبدالرحمن بن أبي حاتم : سمعت أبي يقول: هشام بن عمار لماكبر

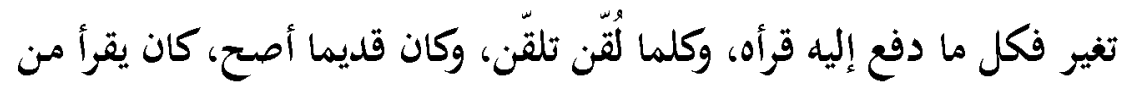

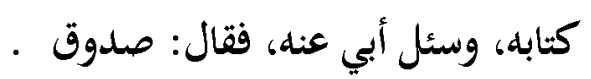

وقال الدارقطني : صدوق، كبير المحل وقال المروذي عن أحمد بن

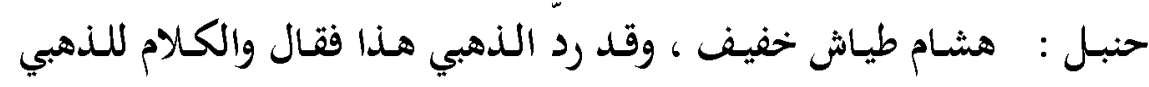

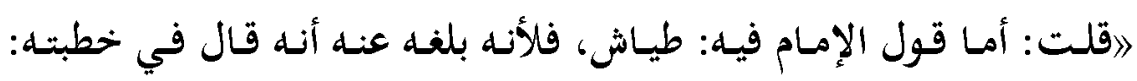

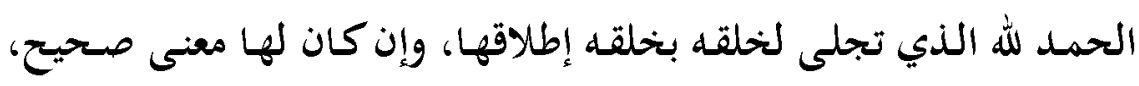
لكن يحتج بها الحلولي والاتحادي. وما بلغنا أنه سبحانه وتعالى تجلى لشيء إلا بجبل الطور، فصيره دكا. 


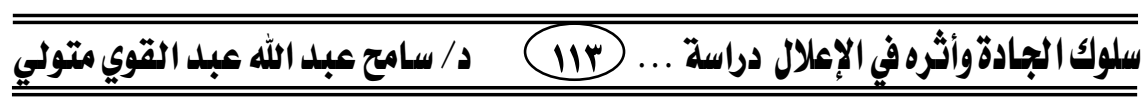

وفي تجليه لنبينا -صلى الله عليه وسلم- اختلاف أنكرته عائشة، وأثبته ابن العباس.

وبكل حال: كلام الأقران بعضهم في بعض يحتمل، وطيه أولى من بثه، إلا

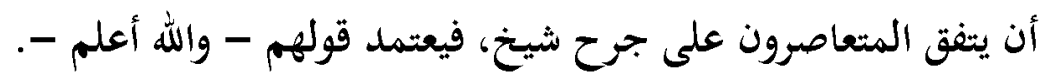

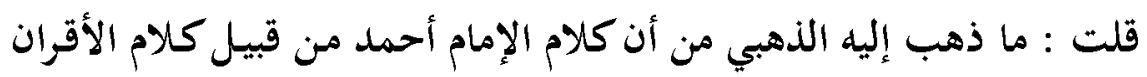
ليس بصحيح؛ لأن الإمام أراد بيان بدعة الراوي.

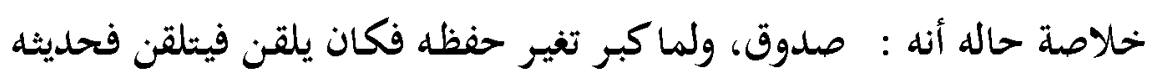

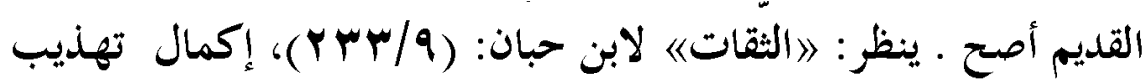

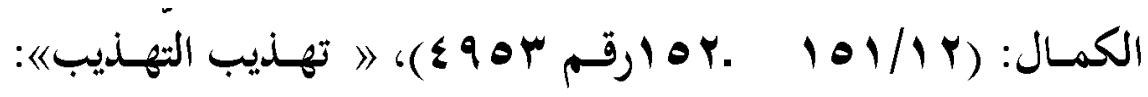

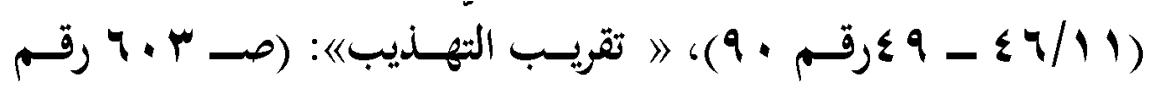
. (VT.T

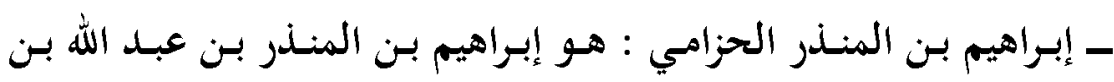

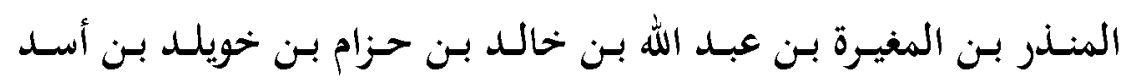
الأسدي، الحزامي، أبو إسحاق المدني.

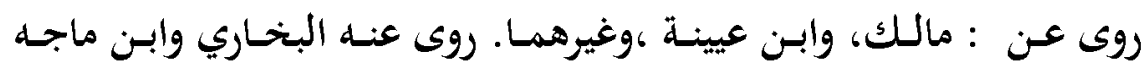
وغيرهما.

قال عثمان الدارمي: رأيت ابن معين كتب عن إبراهيم بن المنذر أحاديث ابن وهب ظلنتها المغازي.

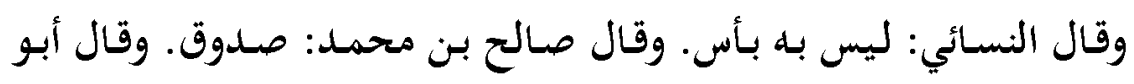

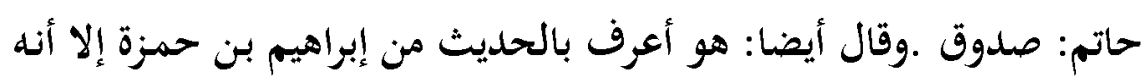

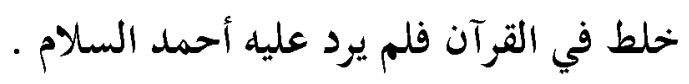




\section{مجلـة اللدرايـــة"ة}

وقال الساجي: بلفني أن أحمد كان يتكلم فيه ويذمه وكان قدم إلى ابن أبي

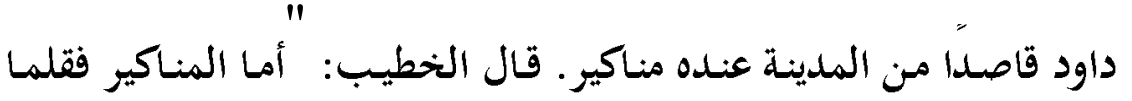
توجد في حديثه إلا أن يكون عن المجهولين ومع هـذا فإن يحيى بن معين إندان وغيره من الحفاظ كانوا يرضونه ويوثقونه ـ وقال الدارقطني: ثقة ـ وذكره ابن

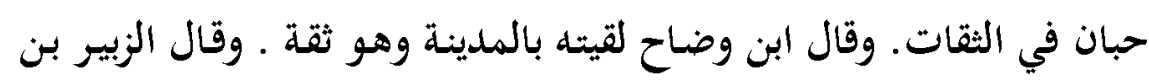
بكار: كان له علم بالحديث ومروءة وقدر. وقال ابن حجر : صددوق تكلم

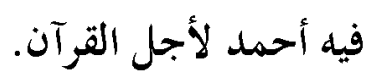

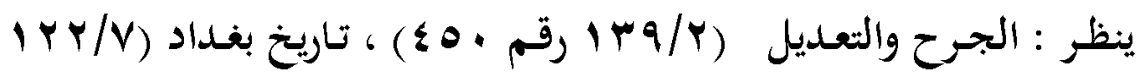

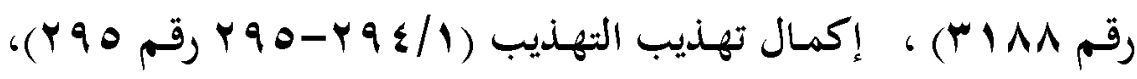

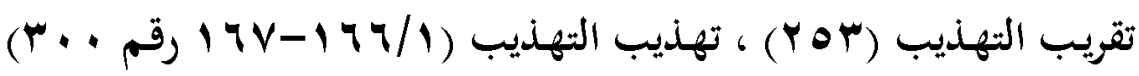

ـ محمـد بـن الصسباح : هـو محمـد بـن الصسباح بـن سفيان بـن أبي سفيان الجرجرائي، أبو جعفر التاجر مولى عمر بن عبد العزيز.

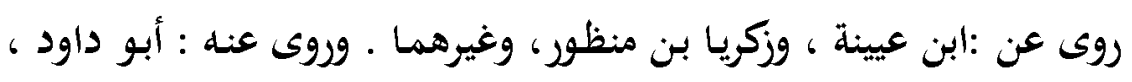
وابن ماجه ،وابنه جعفر بن محمد بن الصباح، وأبو زرعة الرازي ، وغيرهم. خلاصة القول فيه أنه : صدوق.

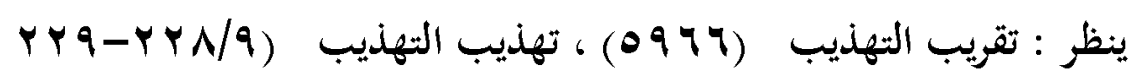

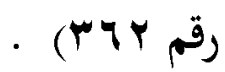

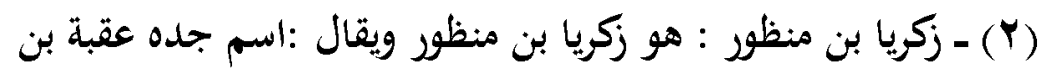

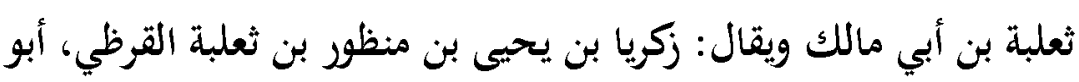
يحيى المدني ، القاضي ، حليف الأنصار . 


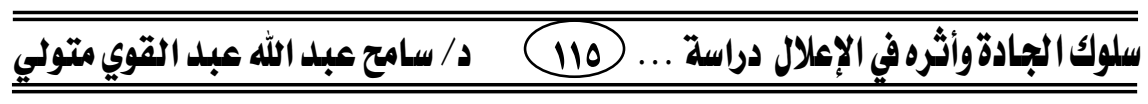 \\ خلاصة حاله أنه : ضعيف.}

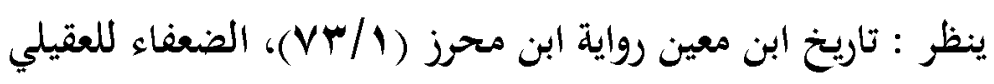

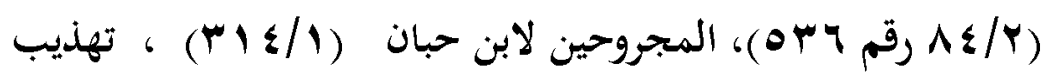

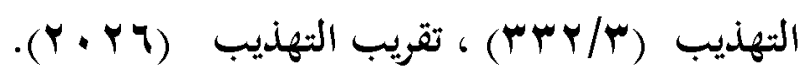

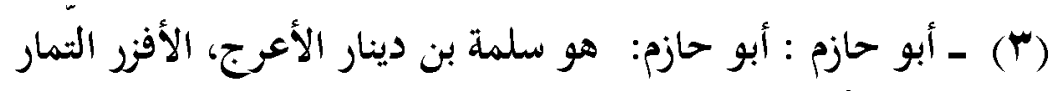

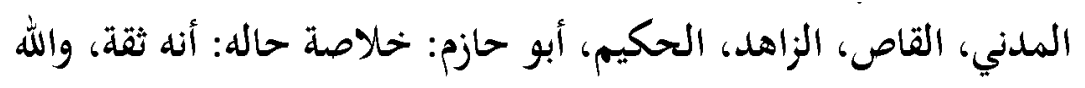

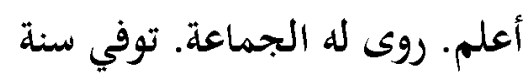

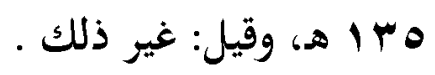

ينظر: تهذيب الكمال (1 (YO. Y

( ) - سهل بن سعد : هو سهل بن سعد الساعدي: هو سهل بن سعد بن مالك بن خالد بن ثعلبة الأنصاري، الساعدي، المدني، أبو العباس، ويقال: أبو يحيى: صحابي مشهور. توفي سنة ^هد، وقيل: بعدها، وقد تجاوز المائة سنة، وهو آخر من مات من الصحابة في المدينة.

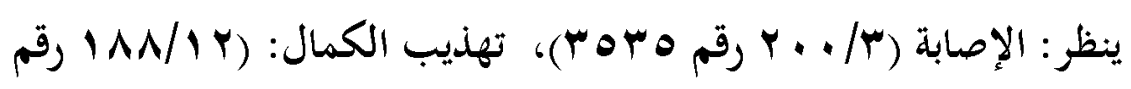

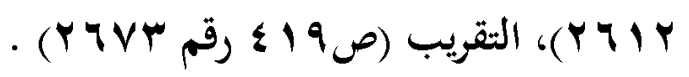
دراسة إسناد الوجه الثاني عند ابن أبي الدنيا في \ذم الدنيا《) : عن خالد بن

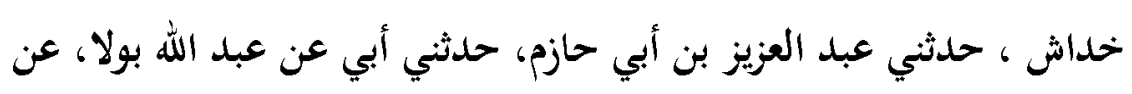




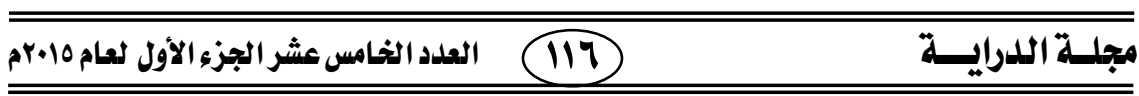

رجل من المهاجرين (1) عن النبي صلى الله عليه وسلم،: أن رسول الله

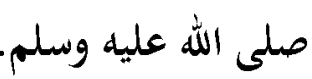

(1) ـ خالد بن خداش : هو خا لد بن خداش بن عجلان الأزدي، المهلّي مولاهم، البصري، أبو الهيثم.

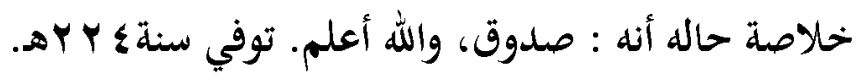

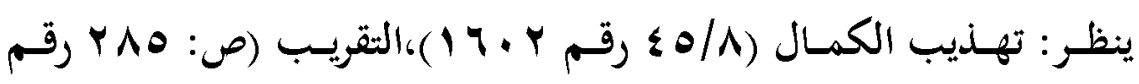
. (19 (Y) - عبد العزيز بن أبي حازم : هو عبد العزيز بن أبي حازم سلمة بن دينار

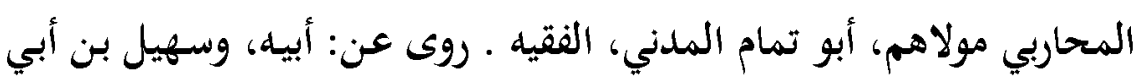
صالح ، وغيرهما . وروى عنه : ابن وهب ، وخالد بن خداش، وغيرهما.

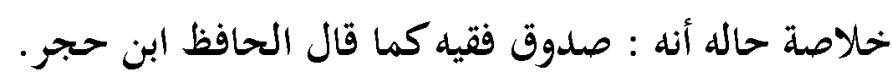

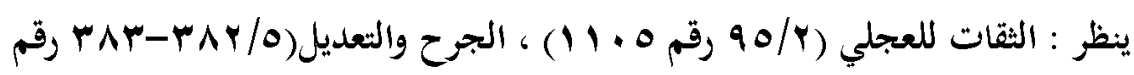
(IVAV

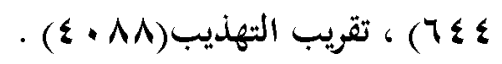

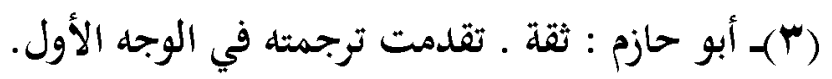

(1) المثبت في الاسناد عبد الله بن بولا عن أيبه في كتاب 》ذم الدنياه لابن أبي الدنيا ، وابن قانع

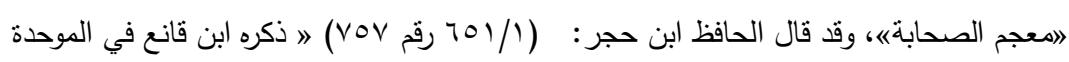

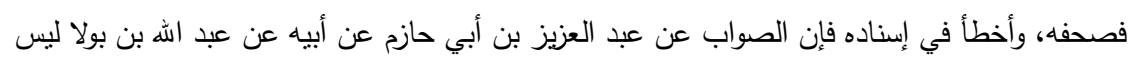
فيه عن أبيه والله أعلمه أهـ. 


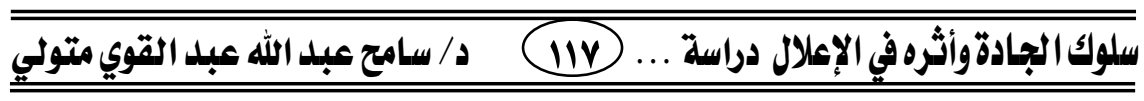

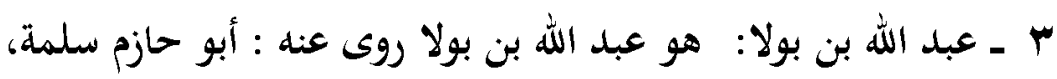

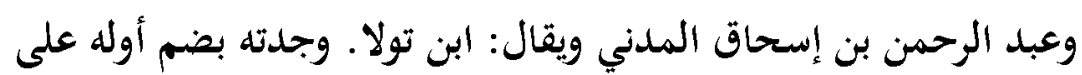

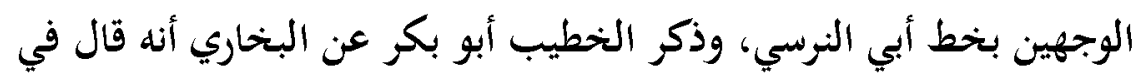

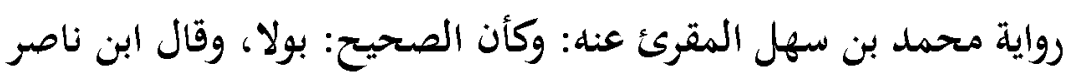
فيما وجدته بخطه على التاريخ في نسخة: وكأن الصحيح: بولي". خلاصة حاله أنه : مجهول الحال.

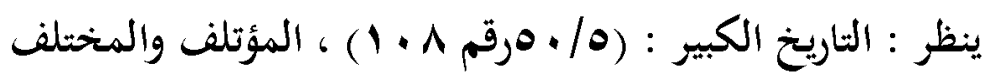

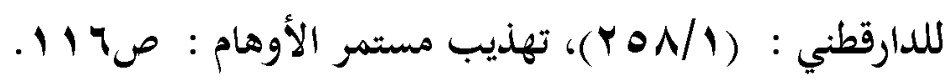

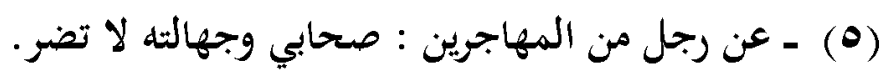

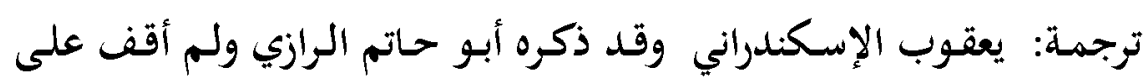
روايته : هو : يعقوب بن عبد الرحمن بـ نن محمد القاريٌٌ المدني، حليف بني زهرة،

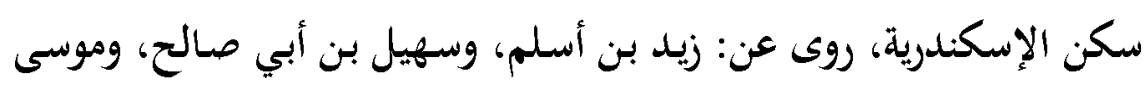

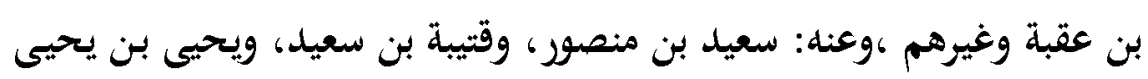
وغيرهم.

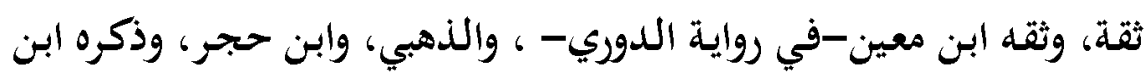

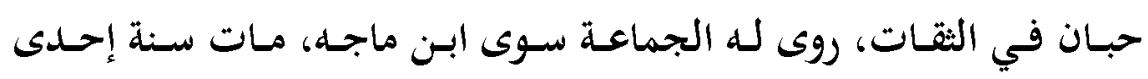
وثمانين ومائة. خلاصة حاله أنه : ثقة. 


\section{مجلـة الدرايــة م}

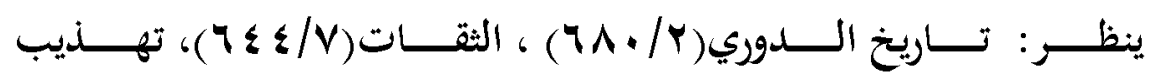

الكمال(r/

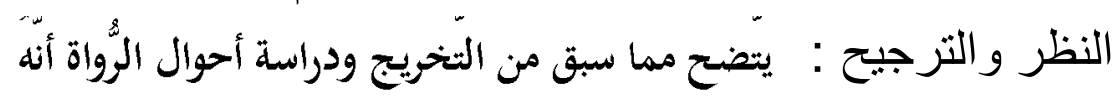

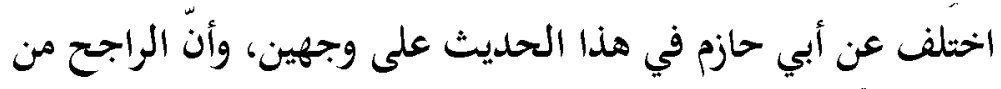

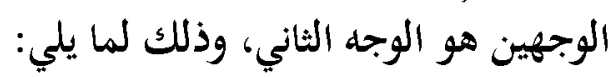
ـ أن هذا الوجه رواه عن أبي حازم يعقوب الإسكندراني وهو ثقة كما تقدم في دواسته

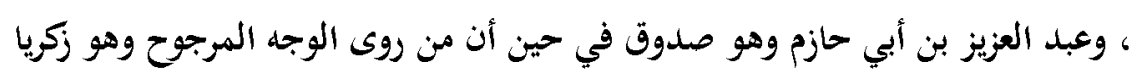
بن منظور وهو ضعيف كما تقدم في دراسته

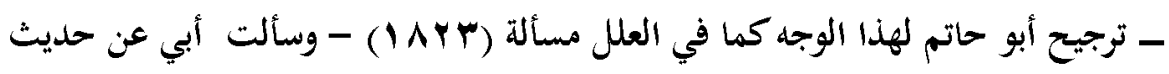

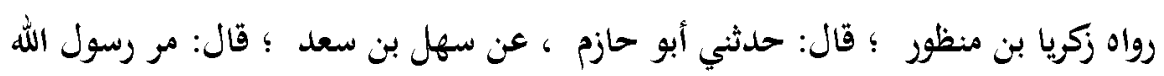

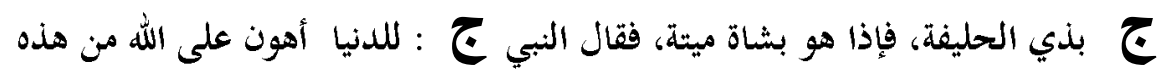

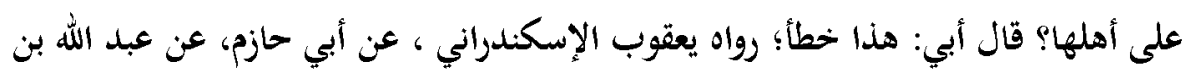
بولا ، عن رجل من المهاجرين، عن النبي ج ، وهذا أشبه، وزكريا لزم الطريق. قلت: ما حال زكريا هذا؟ قال: ليس بقوي. الحكم على الحديث : الحديث من وجها الراجح ضال ضعيف؛ لحال عبد الله بن بولا كما تقدم في دراسته ، ولكنه يرتقي بشاهده عند مسلم في

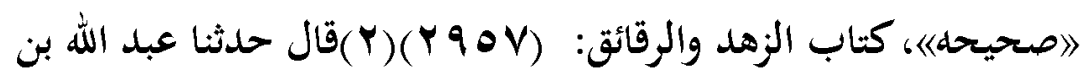

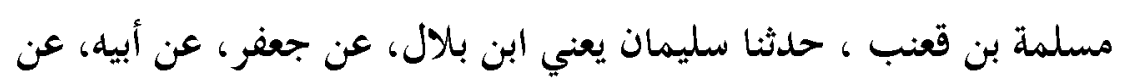

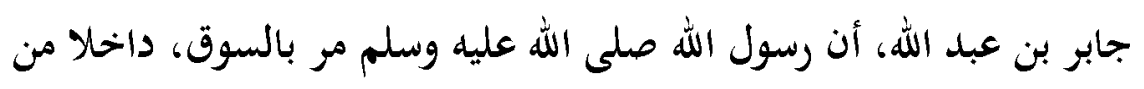
بعض العالية، والناس كنفته، فمر بجدي أسك ميت، فتناوله فأخذ بأذنه، ثم قال: 》أيكم يحب أن هذا له بدرهم:《) فقالوا: ما نحب أنه لنا بشيء، وما

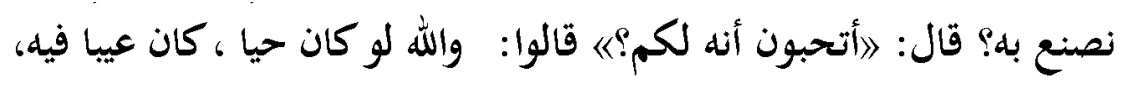




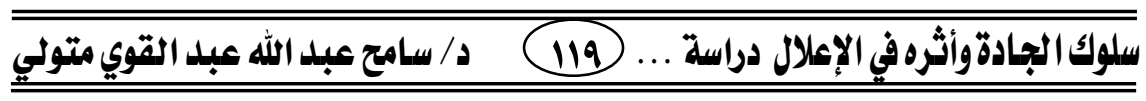

لأنه أسك، فكيف وهو ميت؟ فقال: 》فو الله للدنيا أهون على الله، من هذا

$$
\text { عليكمب. }
$$

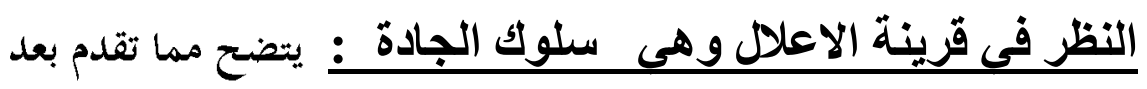

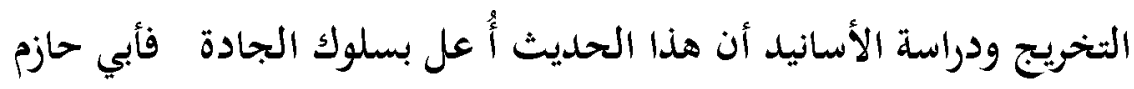
عن سهل بن سعد عن النبي ج جادة تسبق إليها الألسنة وهي سهلة في

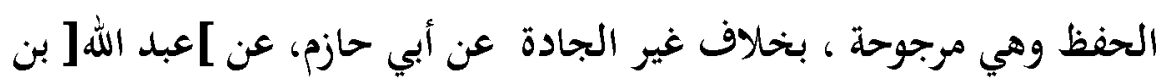

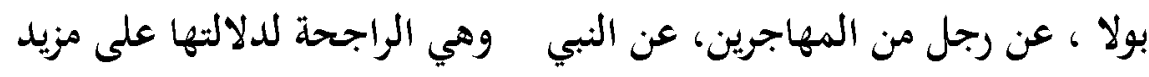

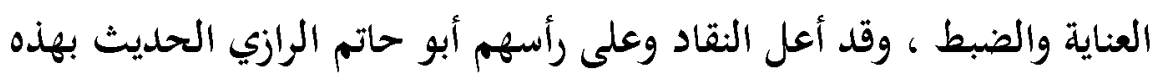
القرينة. 


\section{مجلـة الدرايــة م}

\section{المسألة السادسة}

مسألة رقم(Y T Y Y) وسألت أبي عن حديث رواه الوليد بن عبد الله بن جميع،

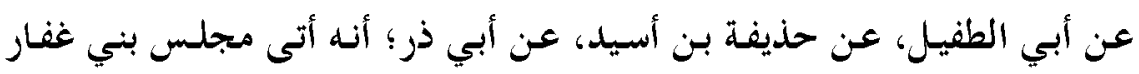
فقال: حدثني الصـادق المصدوق ج : أن الناس يحثرون ثلاثة أفواج: فوجا

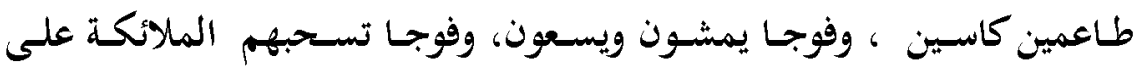

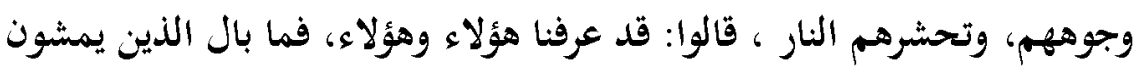

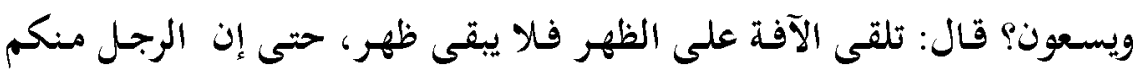

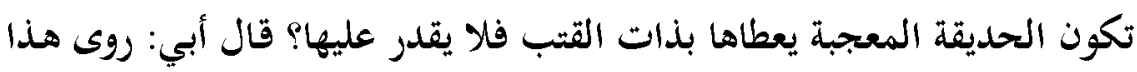

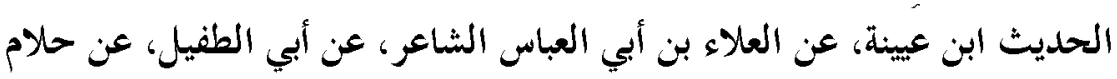
بن جزل، عن أبي ذر، عن النبي ج ، وهو الصحيح، ولزم الوليد بن جميع

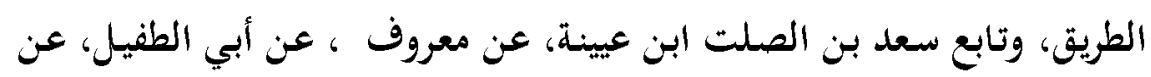

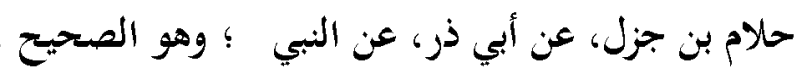

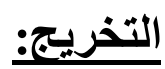
هذا الحديث يرويه أبو الطفيل ، واختلف عنه على وجهين:

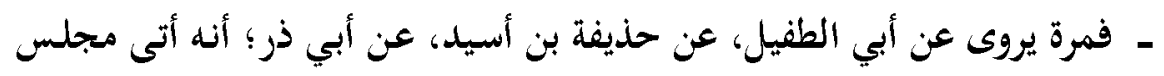
بني غفار فقال: حدثني النبي ج ج

- ومرة يروى عن أبي الطفيل، عن حلام بن جزل، عن أبي ذر، عن النبي ج 


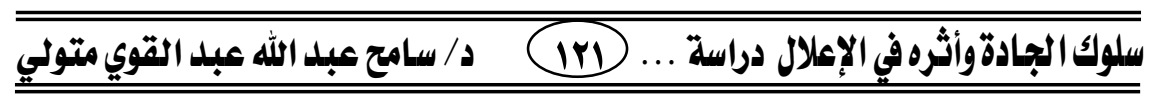

الوجه الأوّل:

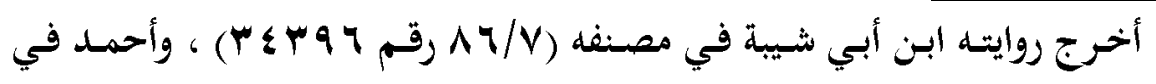

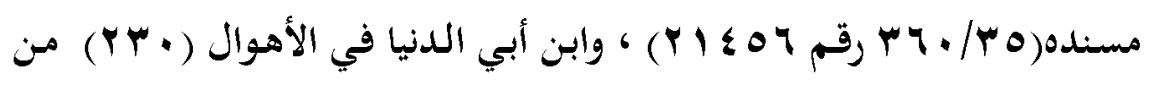

\section{طريق يزيد بن هارون،}

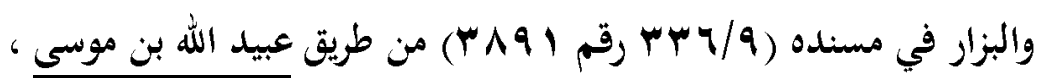

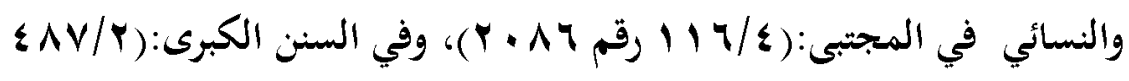

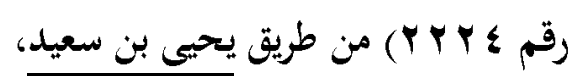

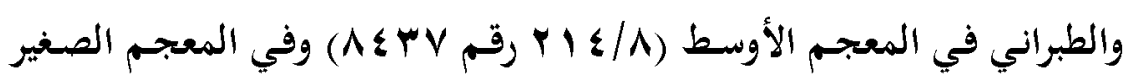

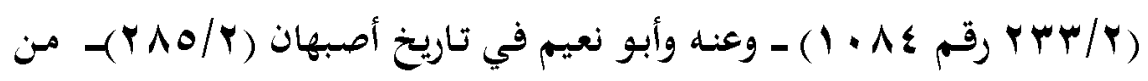

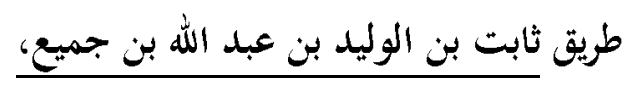

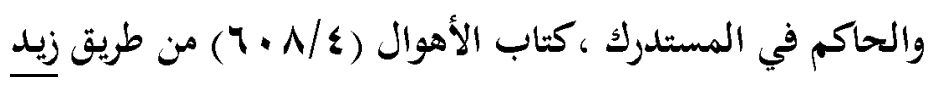

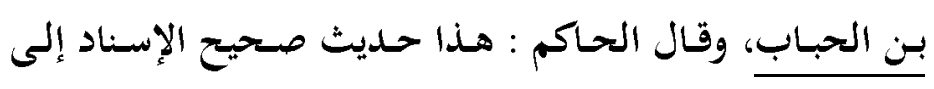
الوليد بن جميع ولم يخرجاه

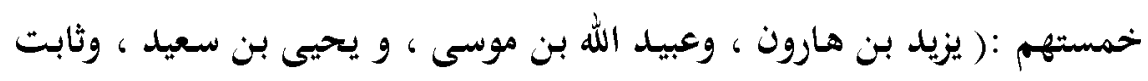

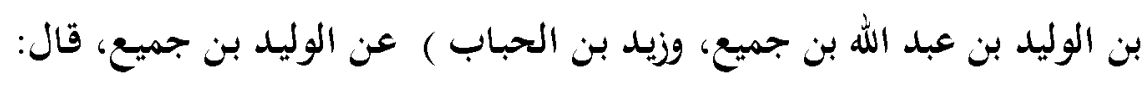

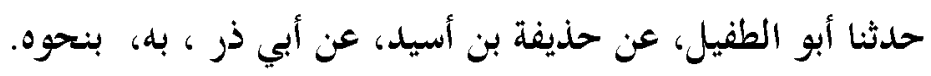

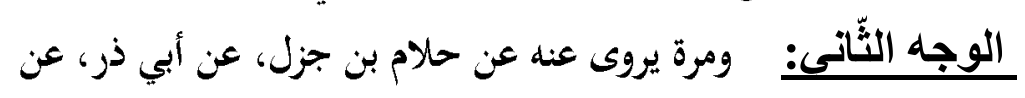
النبي ج لم أقف على رويته بعد البحث والتفتيش.

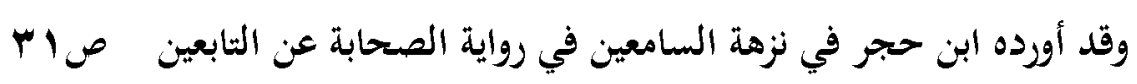




\section{مجلــة اللدرايــةة}

دراسة إسناد الوجه الأول عند أحمد في 》مسنده 《) حدثنا يزيد، أخبرنا الوليد بن

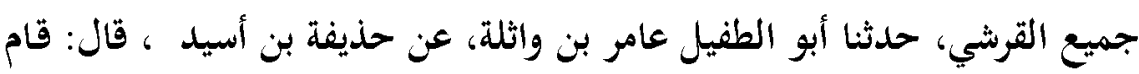

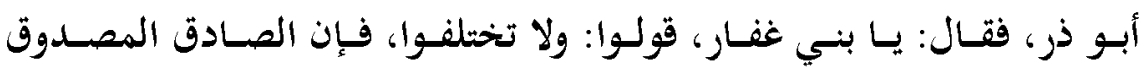
حدثني

(1) - يزيد : هو يزيد بن هارون: هو يزيد بن هارون بن وادي، ويقالُ: زاذان بن

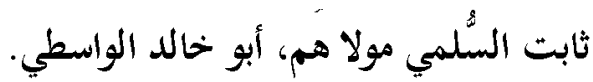

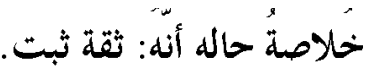

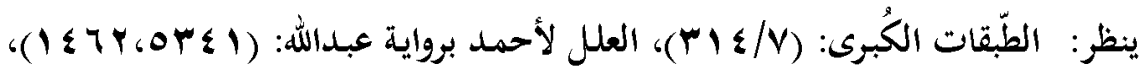

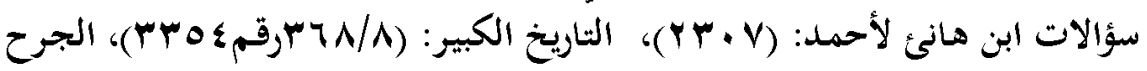

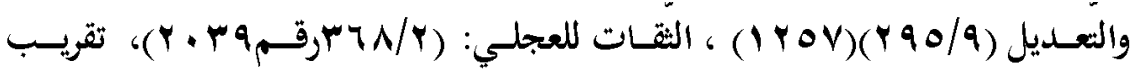

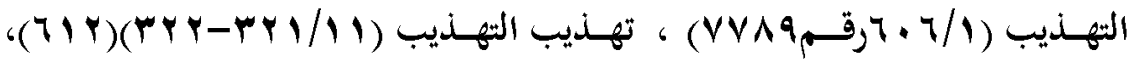
طبقات المدلسين: (YV/I ) (YY).

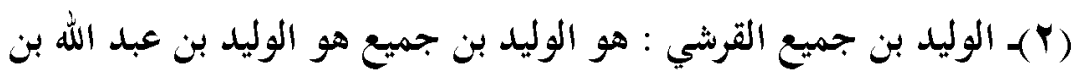

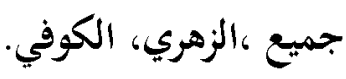
روى عن: مجاهد، وأبي سلمة بن عبد الرحمن، وغيرهما. روى عنه: ابنه ثابت، وحفص بن غياث، وغيرهما. وثثه ابن معين، والعجلي، وابن سعد، وقال أحمد، وأبو داود: ليس بله بأس، وقابل وقال أبو زرعة: لا بأس بله ، وقال أبو حاتم: صالح الحديث، ، وقالئ وقال البزار: احتملوا

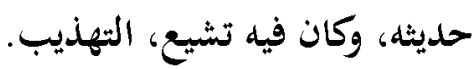
قال عمرو بن علي الصيرفي: كان يحيى بن سعيد لا يحدثنا عن الوليد بن جميع فلما كان قبل موته بقليل حدثنا عنه. خحاصة القول فيه أنه : حسن الحديث وفيه تثيع، والله أعلم.

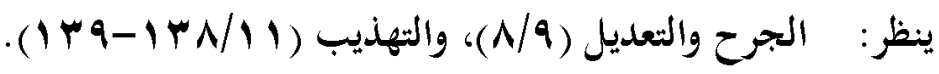




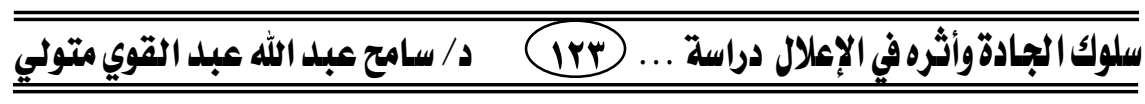

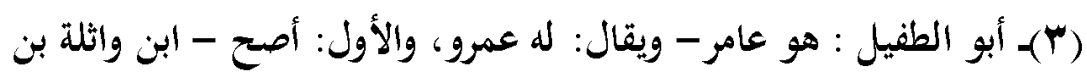

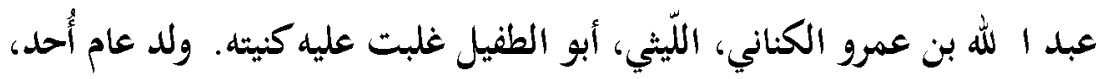

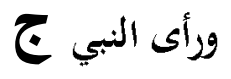

روى عن : النبي ج، وعن ابن عباس ، وغيرهما، وعنه: فطر بن خليفة، وأبو

$$
\text { الزبير، وغيرهما. }
$$

سكن الكوفة، ثم سكن مكة، وأقام بها حتى توفي سنة ـ ـ 11 هـ على الصنى الصحيح

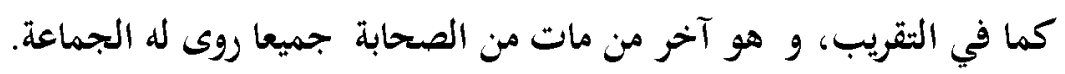

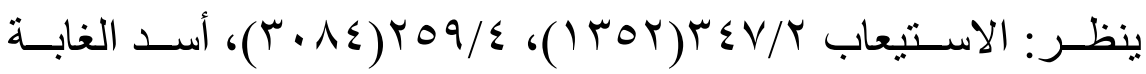

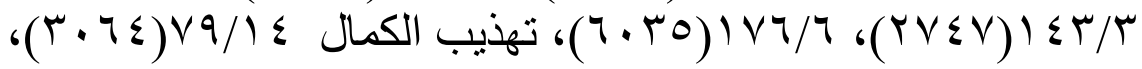
و وس/

$$
\text { ص ص ( }
$$

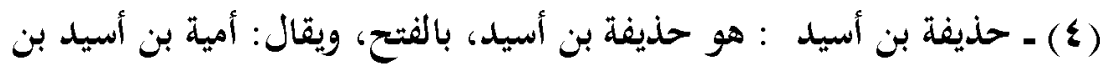

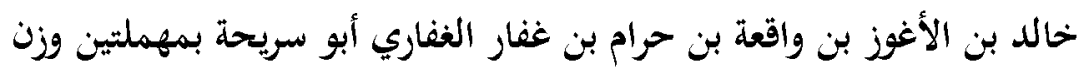

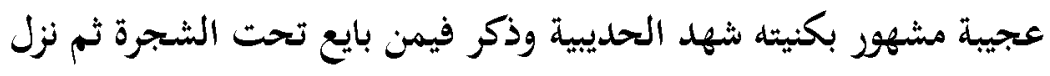

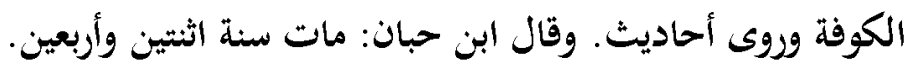

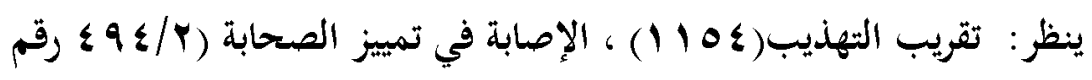

(1708

(0) - أبو ذر : أبو ذر الغفاري الزاهد المشهرز الصادق اللهجة.

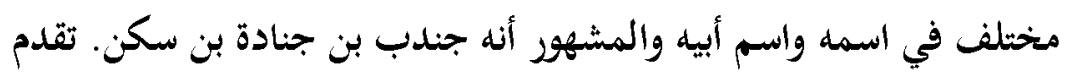

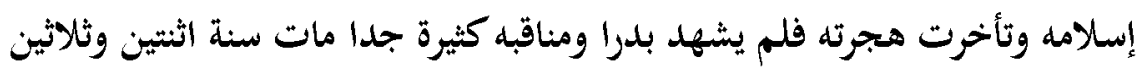
في خلافة عثمان.

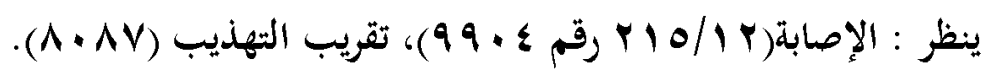

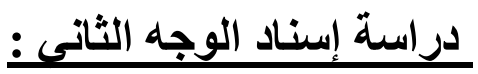




\section{مجلـة اللدرايــة"ة}

لم أقف عليه بعد البحث والثفتيش ونترجم لما ذكره ابن أبي حاتم في هذا الوجه

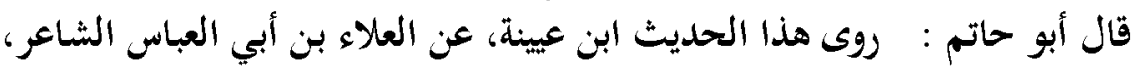

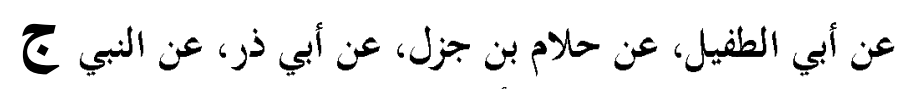

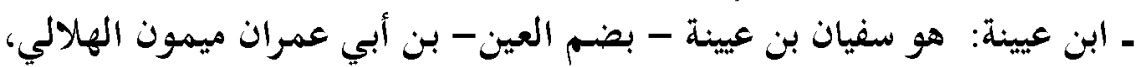

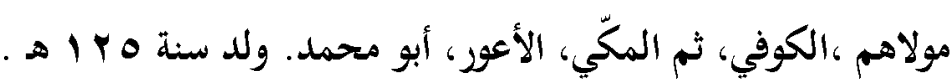

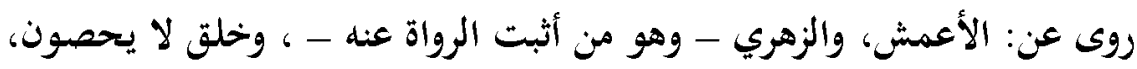
وعنه:

$$
\text { قال الإمام أحمد، وعلي بن المديني، والحميدي ، وطوائف كثيرون . }
$$

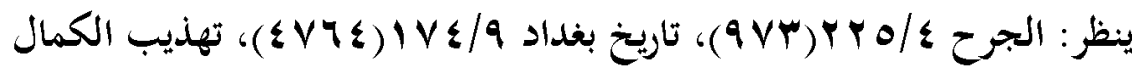

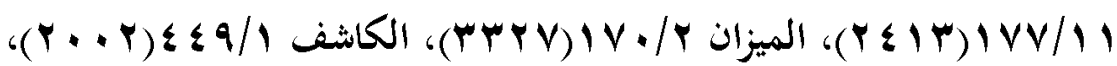

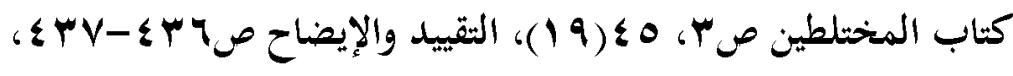

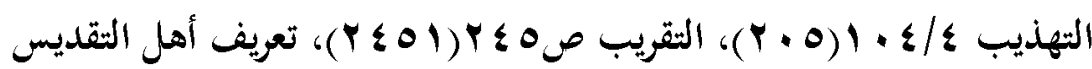

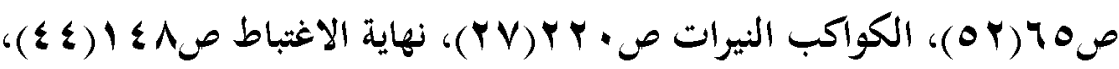

$$
\text { التنكيل (9/1) }
$$

ـ العلاء بن أبي العباس الثاعر: هو العلاء بن أبي العباس الثاعر المكي:

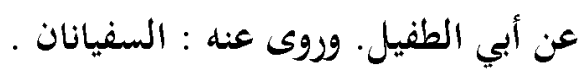

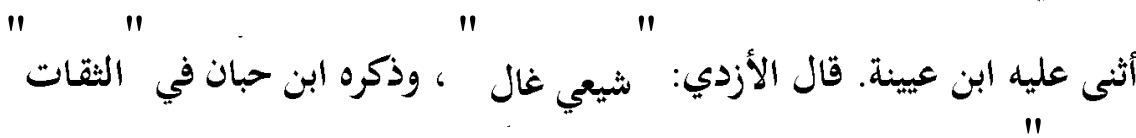
وقال: يروي عن أبي جعفر، وقد روى عن أبي الطفيل إن كان سمع منه. وعنه

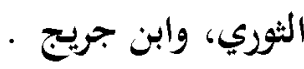




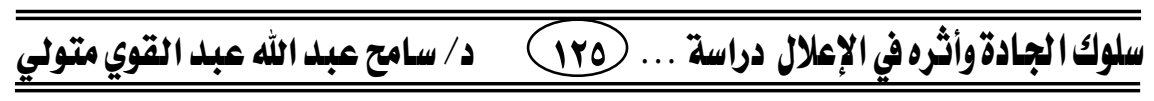

قال ابن معين: ثقة ثقة ـ وقال العجلي: مكي، ثقة. وقال يعقوب بن سفيان:

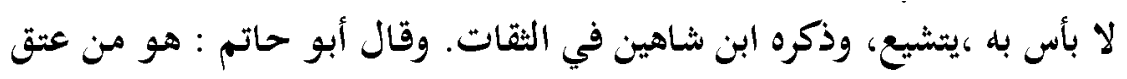
الثيعة.

خلاصة حاله أنه : ثقة.

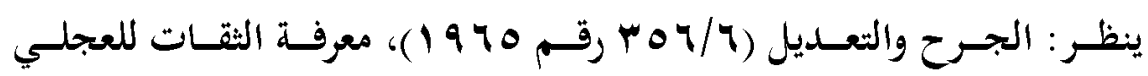

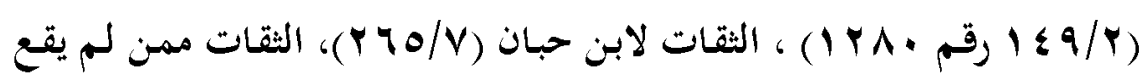

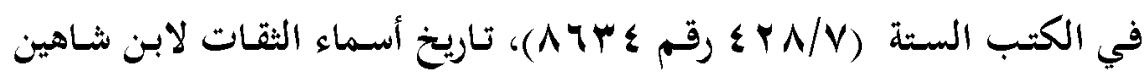

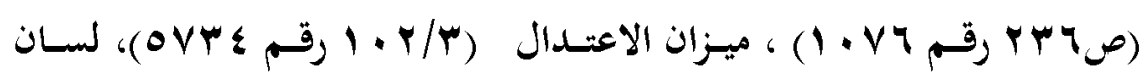

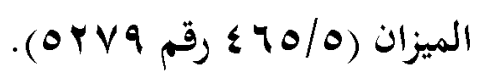
ـ أبو الطفيل: صحابي تقدمت ترجمثله في الوجه الأول.

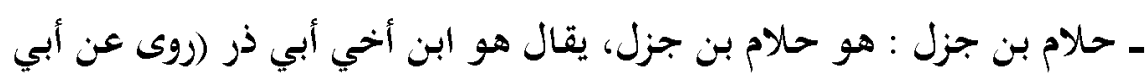

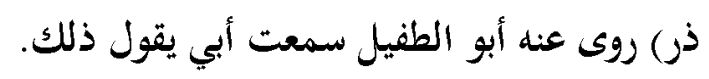
خحلاصة حاله أنه : مجهول. - أبو ذر : صحابي ـ تقدمت ترجمته في الوجه الثاني. 


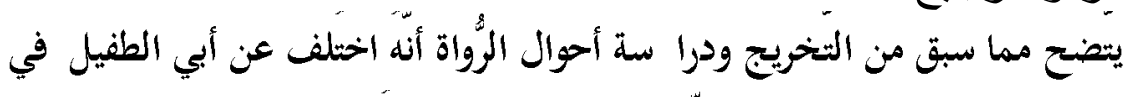

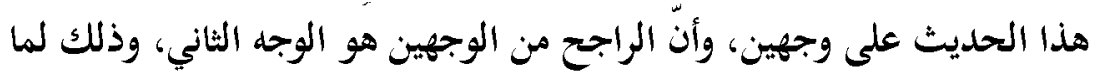

يلي:

ـ أن هذا الوجه رواه عن أبي الطفيل العلاء بن أبي العباس وهو ثقة كما تقدم في

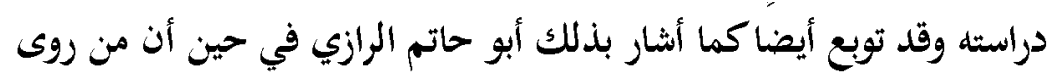
الوجه المرجوح هو الوليد بن جميع وهو لابأس به كما تقدم.

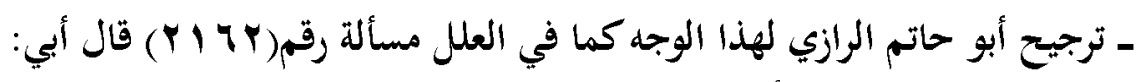

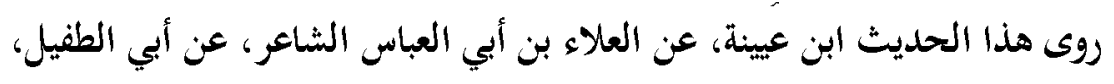

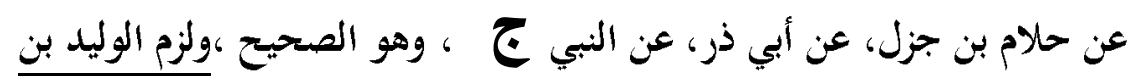

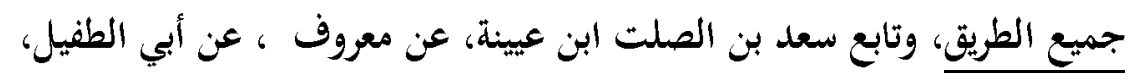

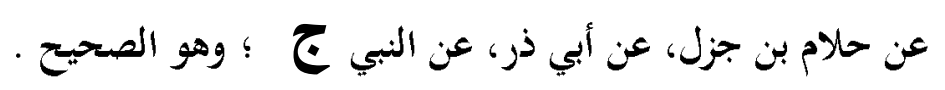

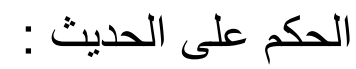

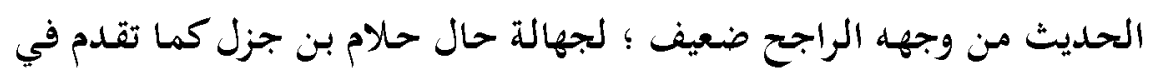

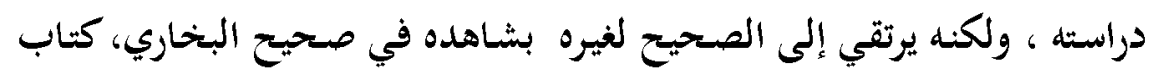

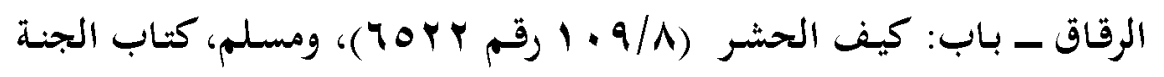

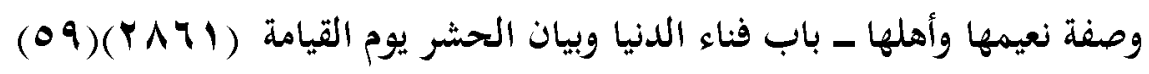

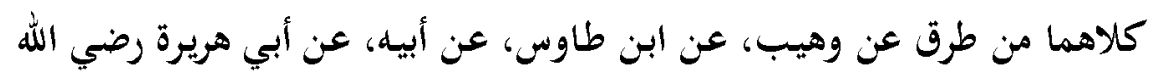

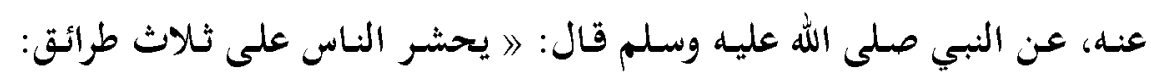

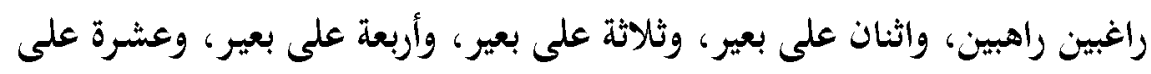

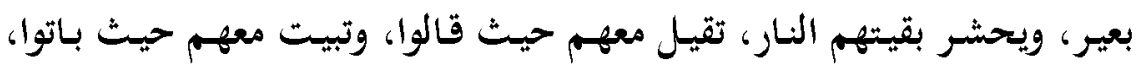

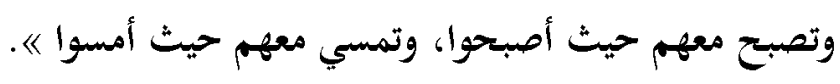




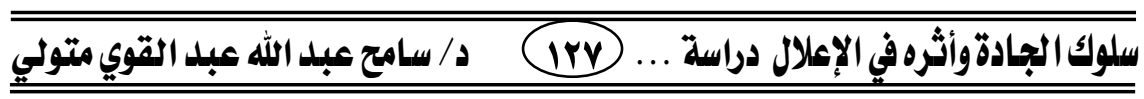

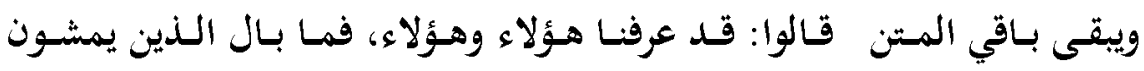

$$
\text { ويسعون؟ قال: }
$$

تلقى الآفنة على الظهر فلا يبقى ظهر ، حتى إن الرجل منكم تكون الحديقة

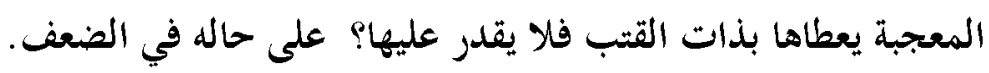

\section{النظر في قرينة الاعلال وهى ( سلوك الجادة ) :}

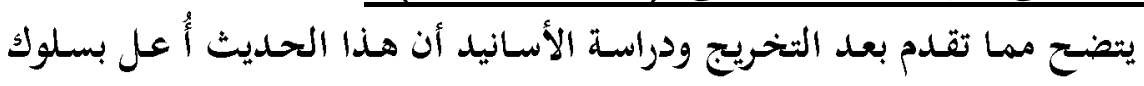

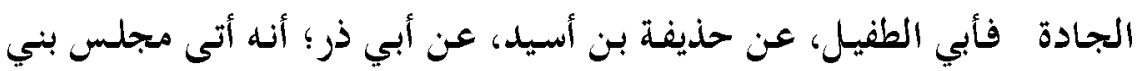

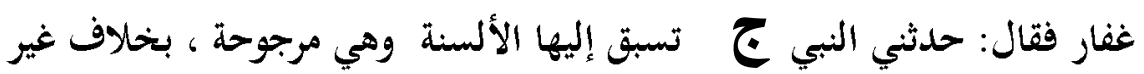

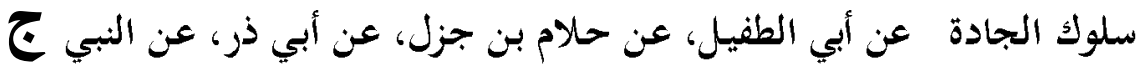

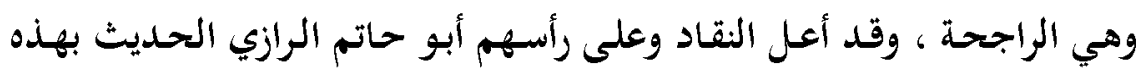

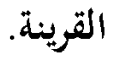




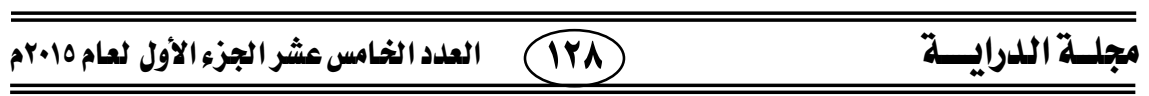

\section{المسألة السابعة}

(Y Y P ) - وسألت أبي عن حديث رواه المبارك بن فضالة ، عن ثابت، عن

أنس، عن النبي ج أنه قال: إذا أحب الرجل أخاه فليعلمه؟

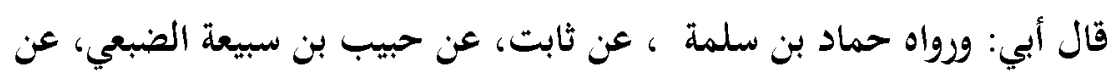
رجل حدثه عن النبي ج ، مرسل. قال أبي: هذا أثبه، وهو الصحيح، وذاكي لزئ لزم الطريق.

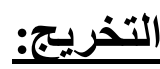
هذا الحديث يرويه ثابت البناني ، واختلف عنه على وجهين:

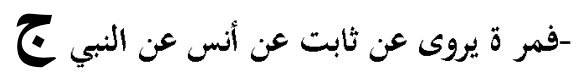
-ومرة يروى عن ثابت عن حبيب بن سبيعة الضبعي، عن رجل حدثه عن النبي ج مرسلا الوجه الأوّل:

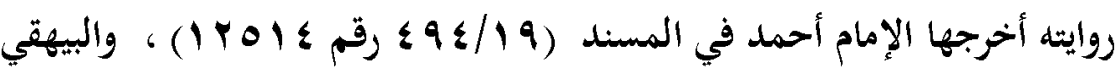

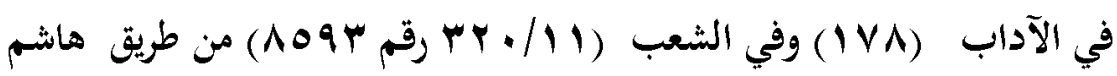

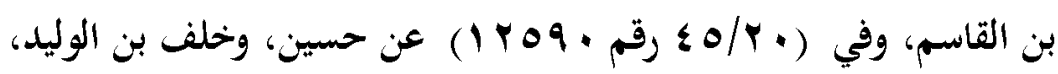
وأبو داود في سننه ، أبواب النوم كباب إخبار الرجل الرجل بمحبثه إياه

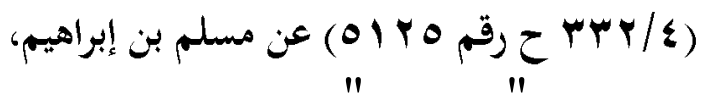

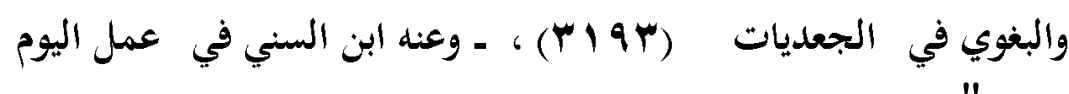

$$
\text { والليلة (19^) }
$$

والحاكم في المستدرك (1 1 199) من طريق موسى بن داود الضبي، 


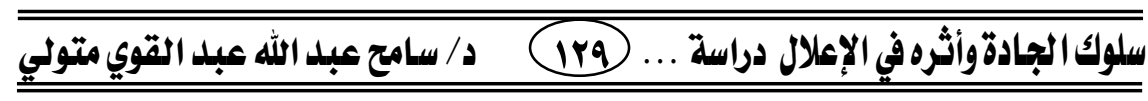

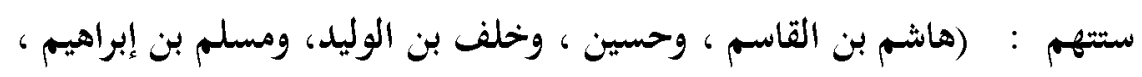

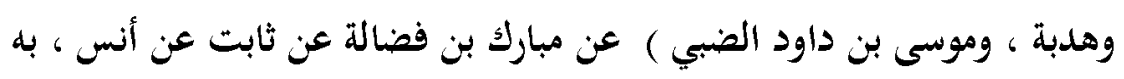
بنحوه.

الوجه الثّانى: ومرة يروى عنه عن حبيب بن سبيعة الضبعي، عن رجل حدثه عن النبي

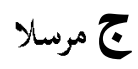

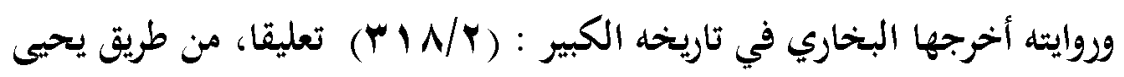

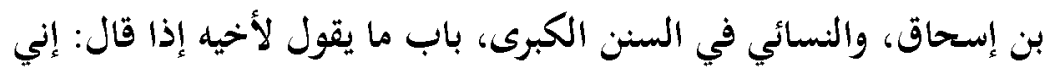

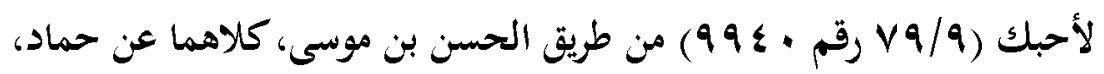
عن ثابت، عن حبي، عن الحارث: أن رجلا كان عند النبي ج . .. ، فذكره،

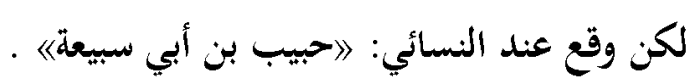

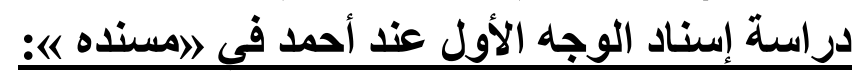

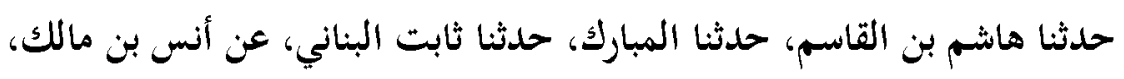

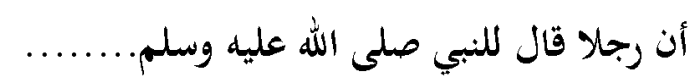

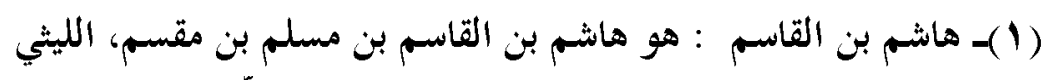

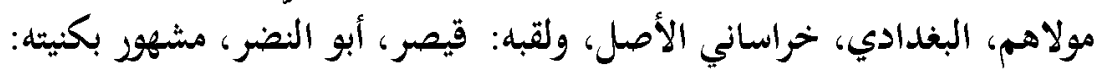
خلاصة حاله أنه ثقة ثبت، والله أعلم.

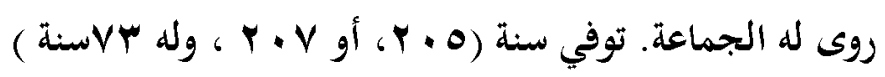

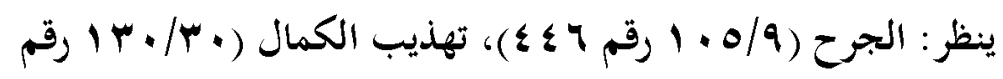

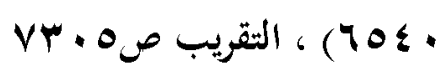

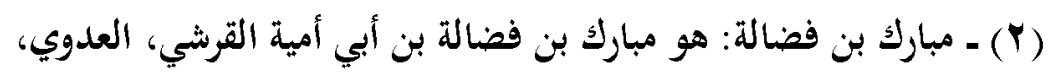

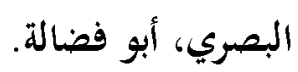




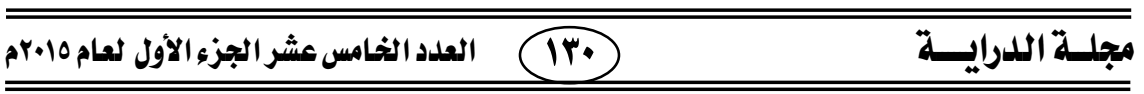

رأى أنس بن مالك س وكان يرسل عنه، وروى عن الأزرق بن قيس - كما في

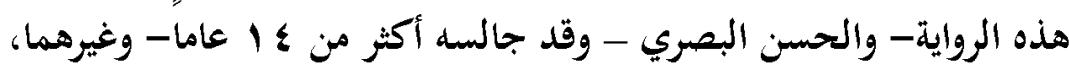

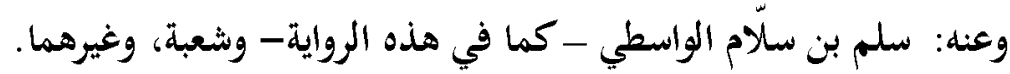

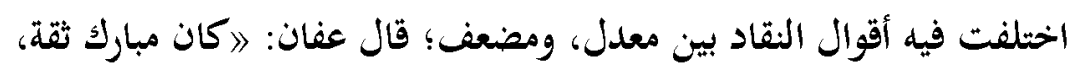

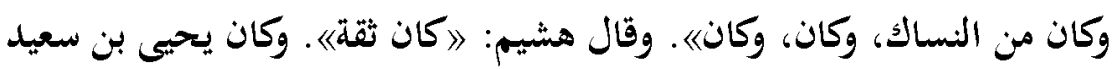

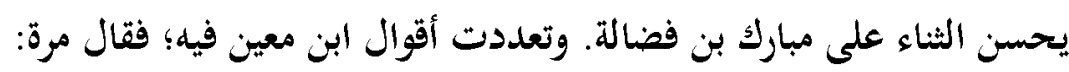

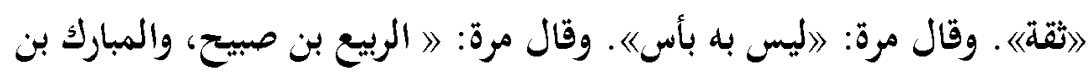

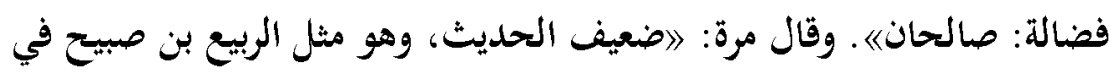

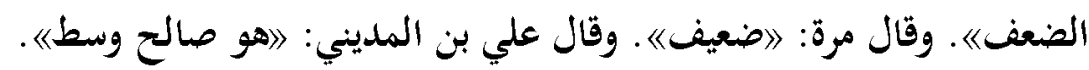

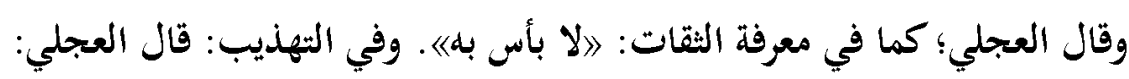

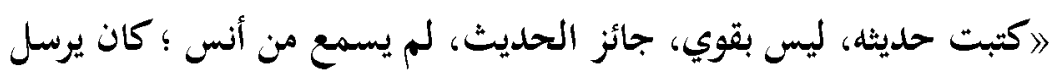

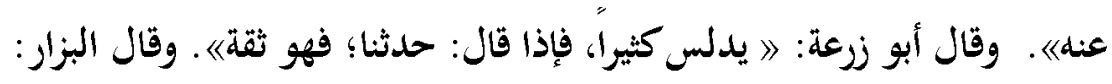

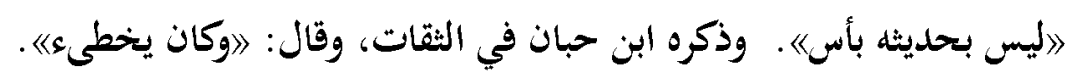

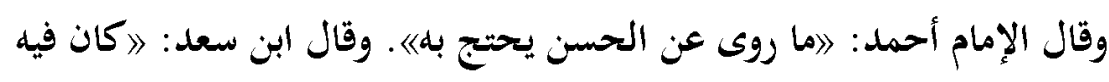

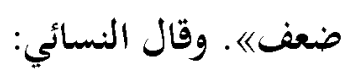
》ضعيف《)

وقال ابن عدي: 》وعامة أحاديثه أرجو أن تكون مستقيمة؛ فقد احتمل من قد رمي بالضعف أكثر ما رمي مبارك بله《. وقال الدارقطني: 》ليس كثير الخطأ يعتبر .

وقد وصفه بالتدليس غير واحد من أهل العلم؛ قال أبو داود: 》كان شديد

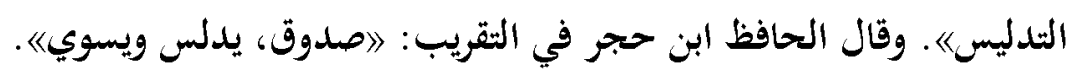

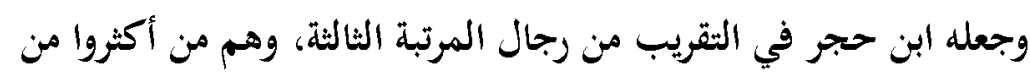
الندليس فلم يحتج الأئمة إلا بما صرحوا فيه بالسماع، ومنهم من رد مط ونلقا. 


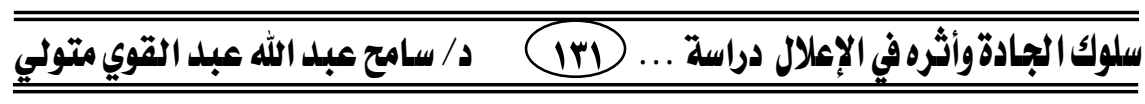

والأقرب في حاله أنه صدوق؛ فقد وثقده كثير من الأئمة مطلقاً، ومنهم من توسط

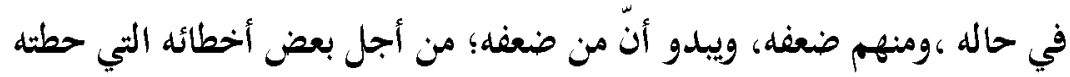
إلى منزلة الصدوق؛ لكنه يدلس؛ كما وصف به أبو زرعة، وأبو داود؛ وعليه فلا

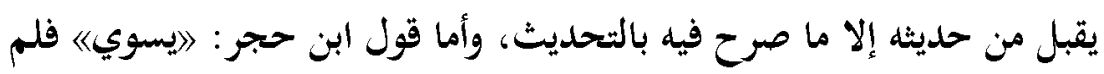

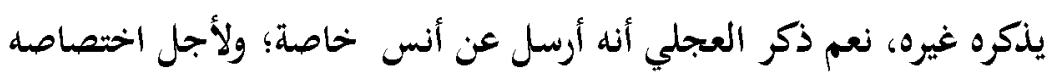

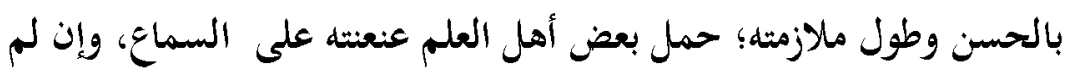

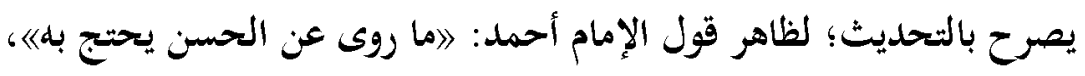

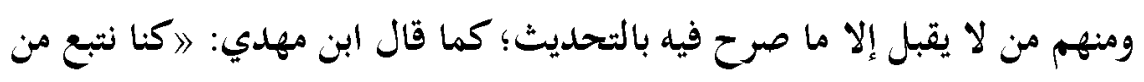

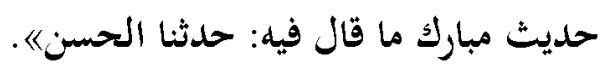

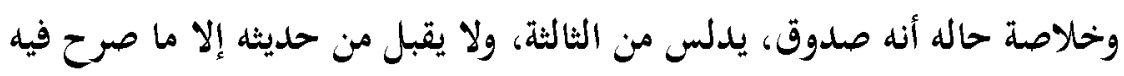
بالتحديث، والله أعلم.

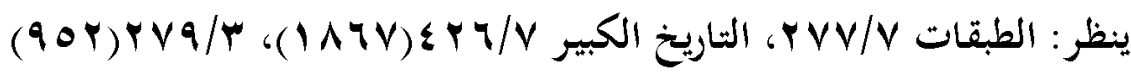

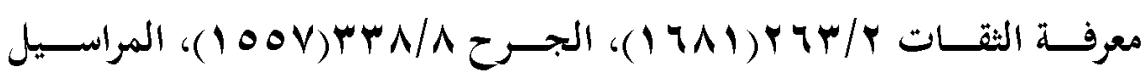

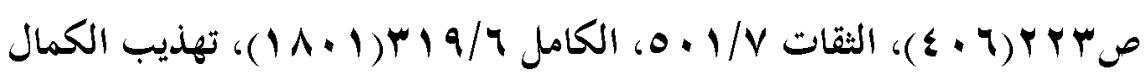

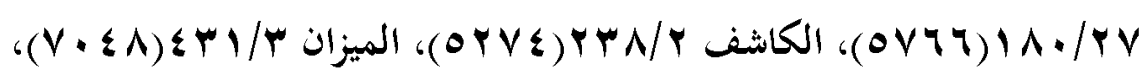

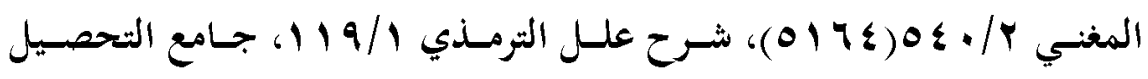

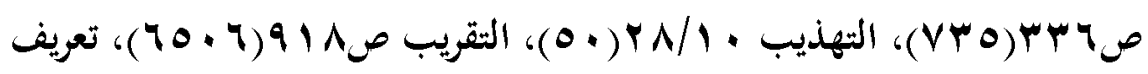

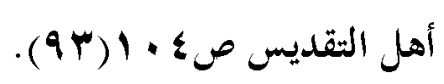

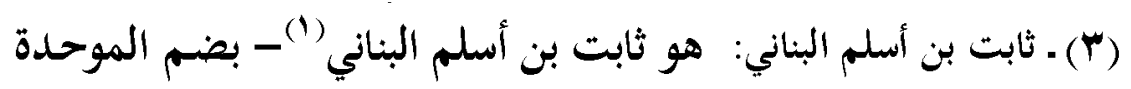

$$
\text { ونونين - ، أبو محمد البصري. }
$$

(1) البُنَانِى: بضم الباء المنقوطة من تحتها بنقطة والنون المفتوحة فهذه النسبة الى بنانة وهو بنانة بن

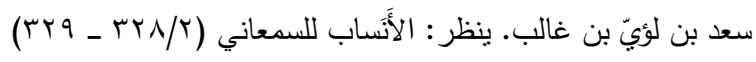




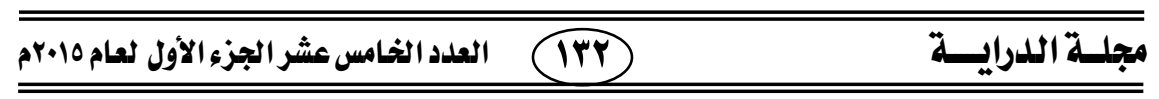

روى عن: أنس، وابن الزُبير، وابن عُمر، وعبد اللّه بن مغفّل، وعَمر بن أبي سلمة، وخلق.

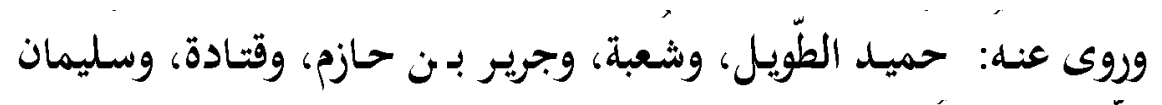
التيمي، وغيرهم. قال ابن سعد: كان ثقة" مأموناً. قال البخاري عن ابن المديني: لله نحو مائتين وخمسين حلديثا. .

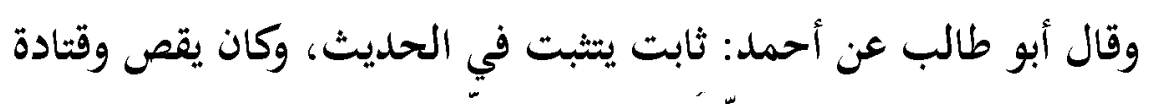
كان يقص وكان أذكر. وثّه ابن معين، والنسائي، والعجلي، وزاد خارجل صالح《، وقال أبو حاتم: أثبت أصحاب أنس الزُّهري ثم ثابت ثم قتادة. وقال ابن حبان في 》الثقاتش《: صحب أنسا أربعين سنة، وكان من أعبد

$$
\text { أهل البعرة. }
$$

وقال ابن حجر: ثقة عابد. مات سنة (Y) I ا هـ)، وله ست وثمانون.

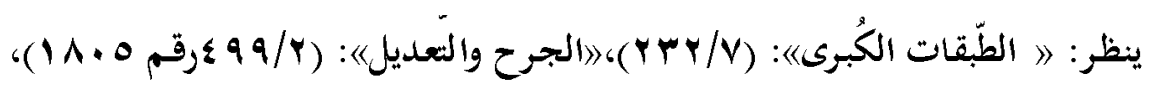

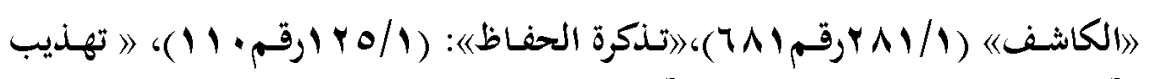

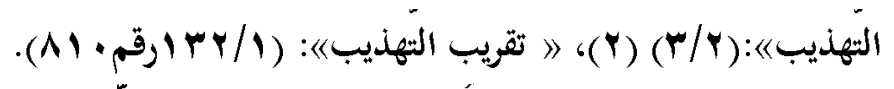

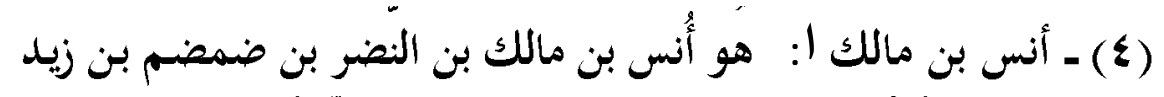

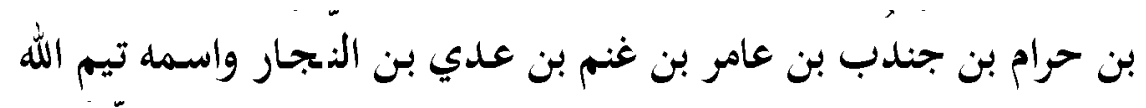

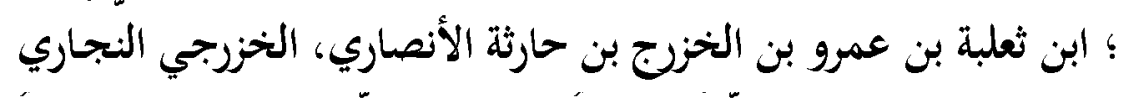

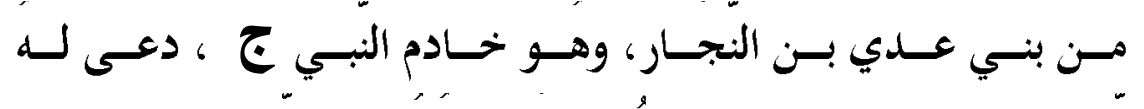

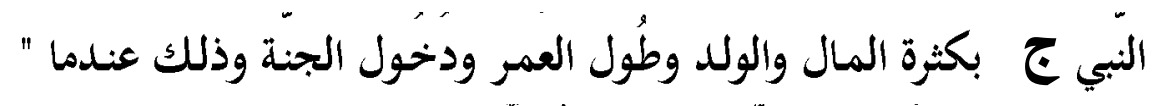

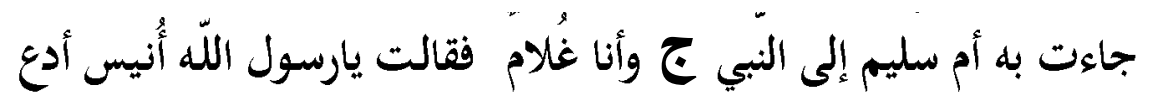




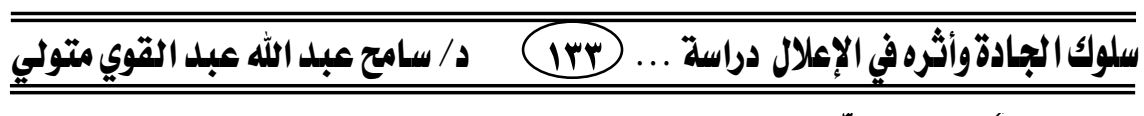

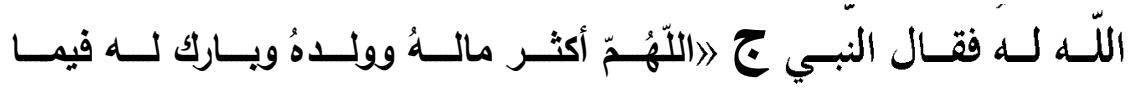

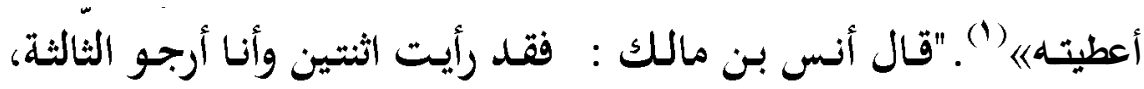
وقال أنس شهدت مع رسول اللّه ج الحديبية وعمرته والحج والفتح وحنينا والطّائف، مات سنة اثنتين وقيل ثلاث وتسعين، وقد جاوز المائة

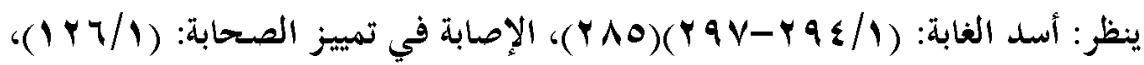

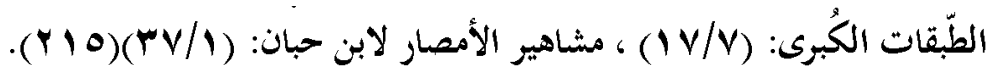

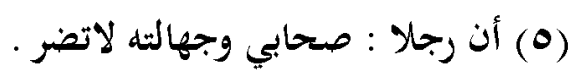

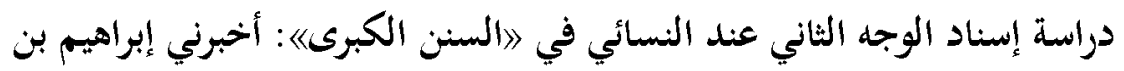

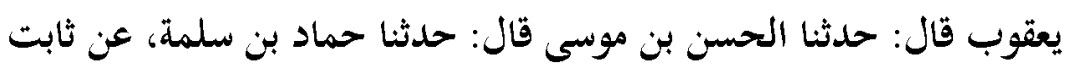

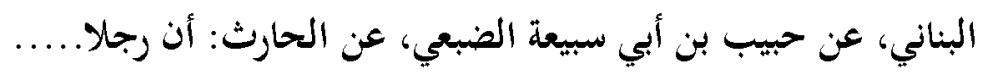

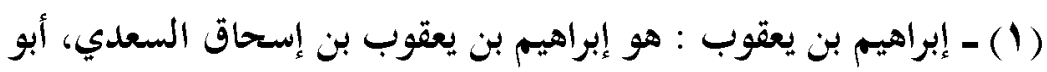

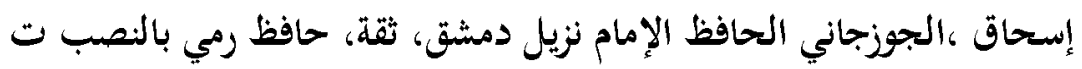
NV9 هـ وله كتاب في الضعفاء اسمه ( أحوال الرجال ) .

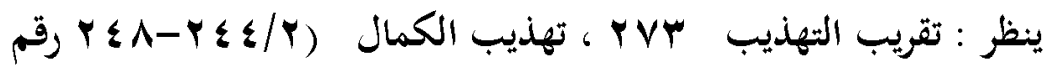
(

(Y) الحسن بن موسى : هو الحسن بن موسى الأشيب، أبو علي البخدادي، قاضي طبرستان، والموصل، وحمص. خحلاصة حاله أنه: ثقة .

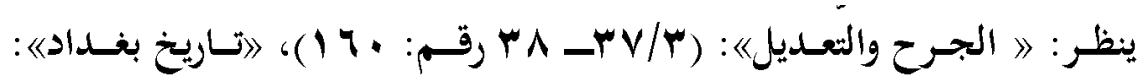




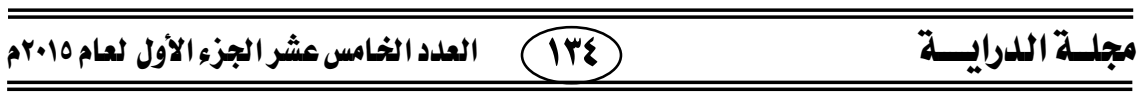

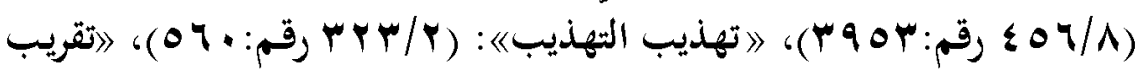

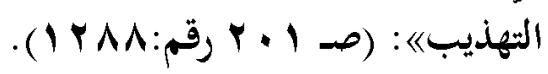

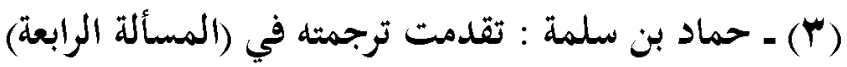

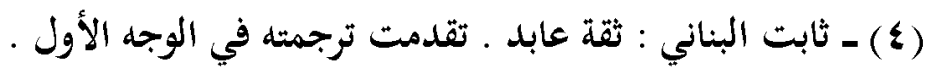

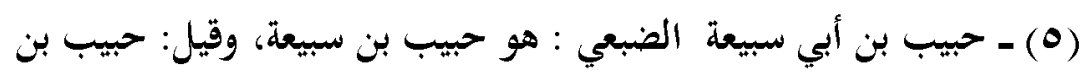

$$
\text { أبي سبيعة ،وقيل: سبيعة بن حبيب الضبعي. }
$$

قال العجلي: ثنامي تابعي ثقة.

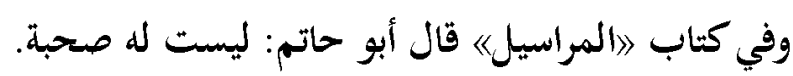

وذكره ابن حبان في 》جملة الثقات《)، قال : ومن قال سبيعة بن حبيب فقد وهم.

وقال ابن حجر : ثقة .

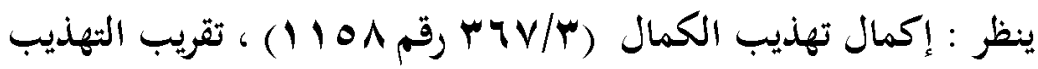

(") - الحارث : صحابي ، له حديث عند ثابت عن حبيب بن أبي سبيعة عنه .

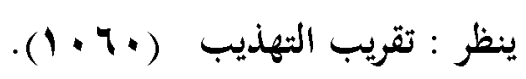

(V)

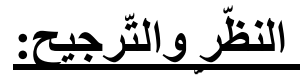

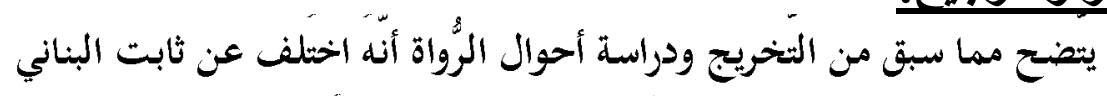

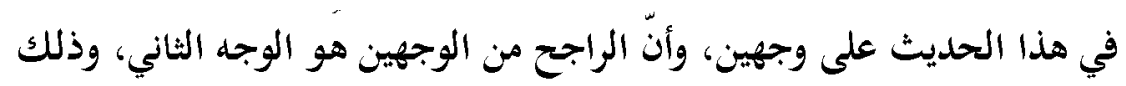
لما يلي: ـ أن هذا الوجه رواه عن ثابت البناني حماد بن سلمة وهو من أثبت الناس فيه ،

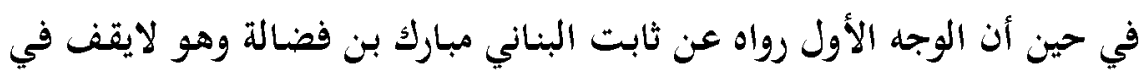
مضمار حماد بن سلمة بأي حال. 


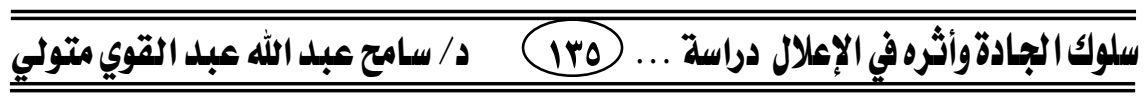

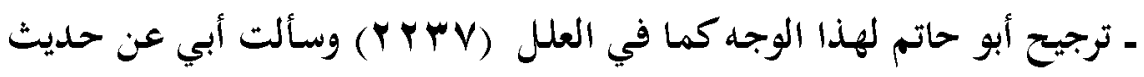

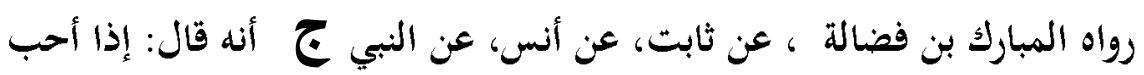

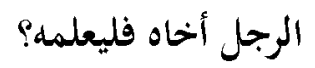

قال أبي: ورواه حماد بن سلمة ، عن ثابت، عن حبيب بن سبيعة الضبعي، عن

$$
\text { رجل حدثله عن النبي ج ، مرسل. }
$$

قال أبي: هذا أشبه، وهو الصحيح، وذاك لزمي لزم الطريق.

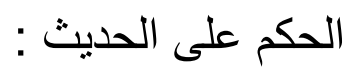

الحديث من وجهه الراجح صحيح ؛ لما تقدم في دراسته.

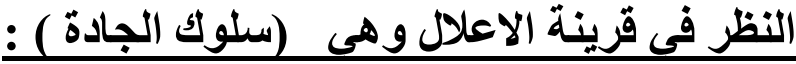

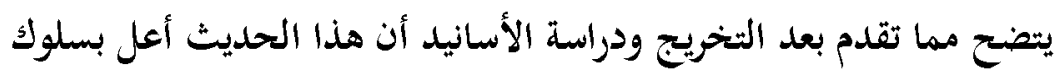
الجادة فعن ثابت عن أنس جادة تسبق إليها الألسنة وهي معروفة ومثهورة ،

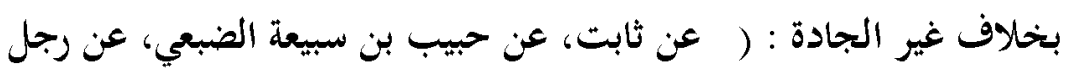

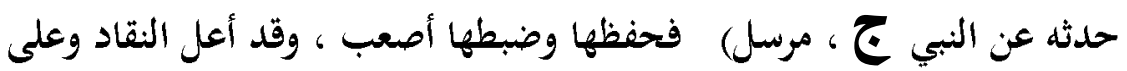
رأسهم أبو حاتم الرازي الحديث بهذه القرينة. 


\section{مجلـة الدرايسـة ة}

\section{المسالة الثامنة}

(Y Y Y 7 ) - وسألت أبي عن ححديث رواه محمد بن إسحاق ، عن الحارث بن عبد الرحيم بن أبي ذباب، عن أبي سلمة ، عن عائشة، عن النبي جن: أكمل المؤمنين

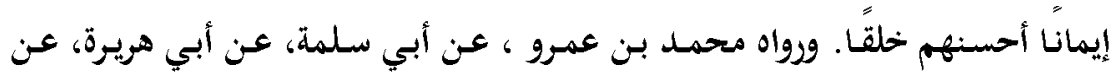
النبي ج ج قال أبي: حديث الحارث أشبه، ومحمد بن عمرو لزم الطريق.

التخريج:

هذا الحديث يرويه أبو سلمة واختلف عنه على وجهين:

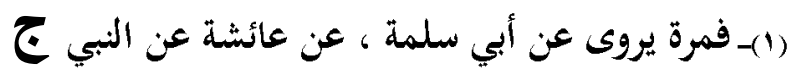

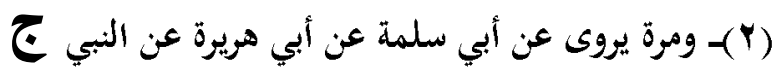

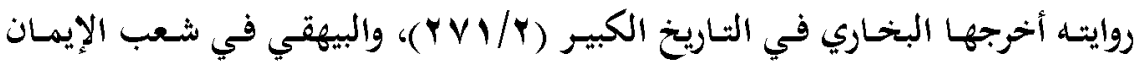

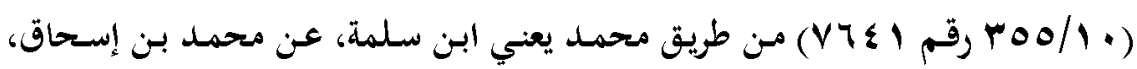

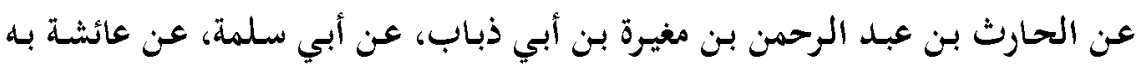
بلفظه.

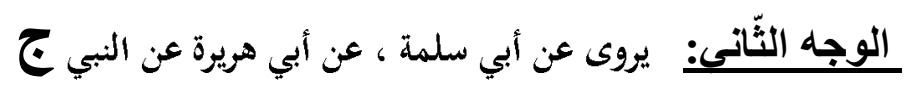

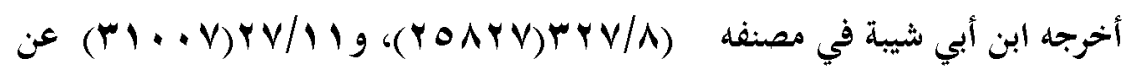

$$
\text { حغص بن غياث، }
$$

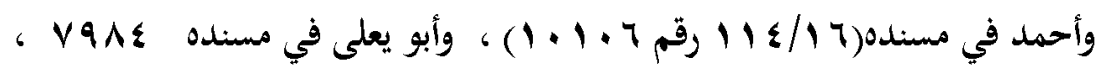

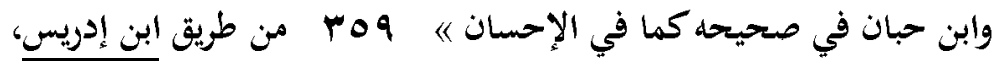

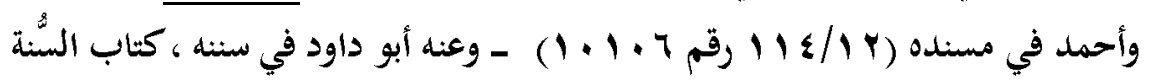

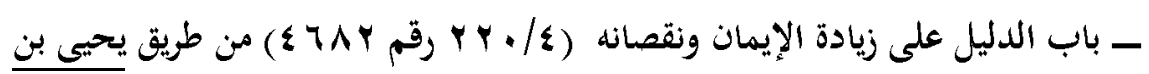

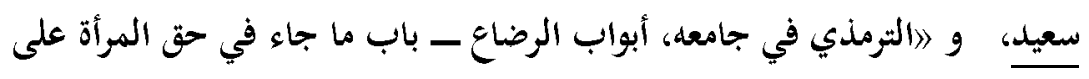

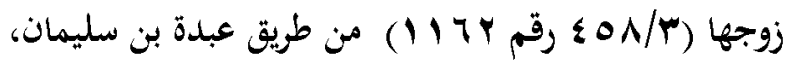




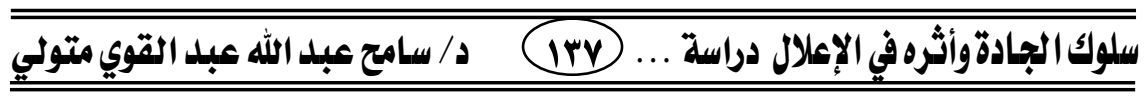

وقال الترمذي عقبه : 》حديث أبي هريرة هذا حديث حسن صحيح) .

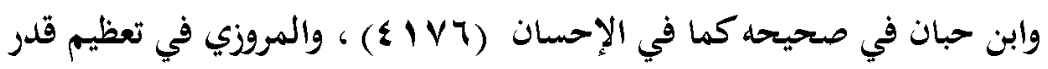

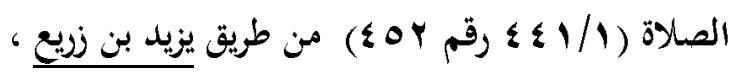

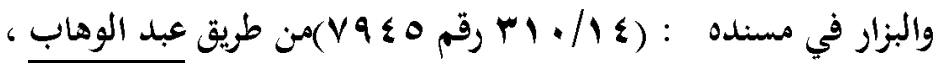

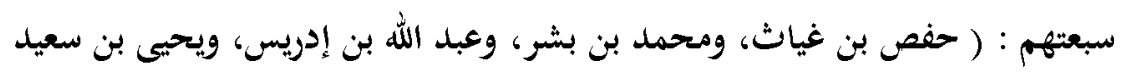

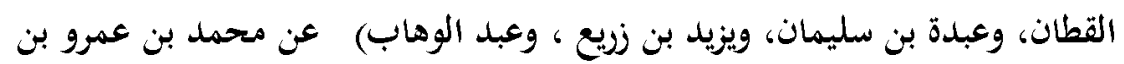

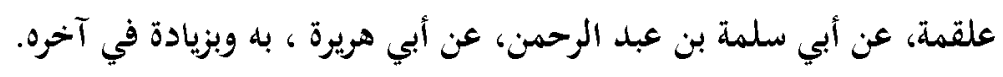

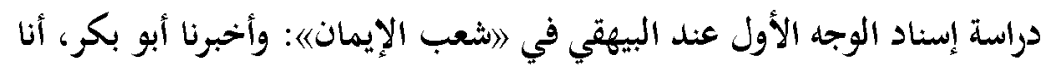

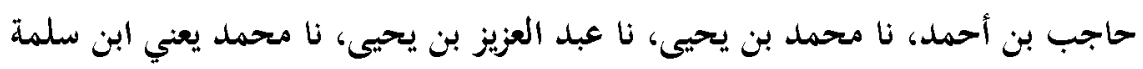

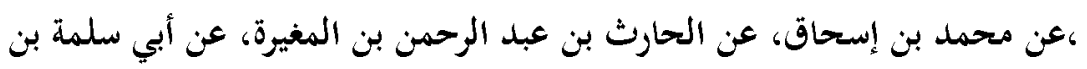
عبد الرحمن، عن عائشة......

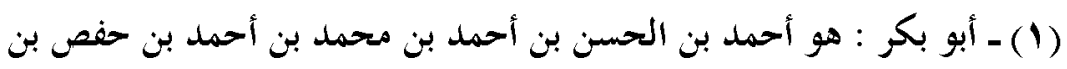

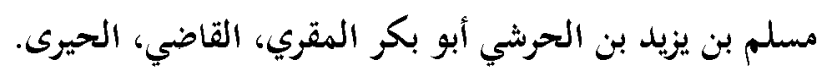
روى عن : حاجب بن أحمد ، ومحمد بن يعقوب الأصم ، وغيرهما.

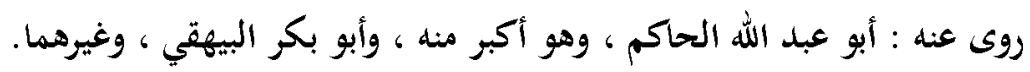

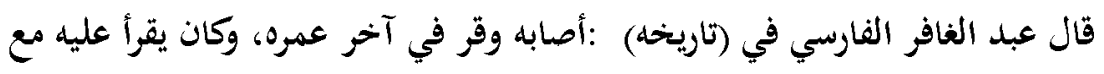

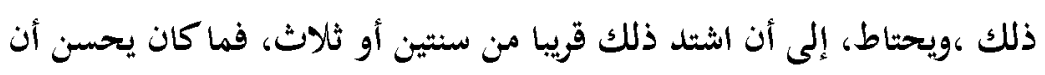

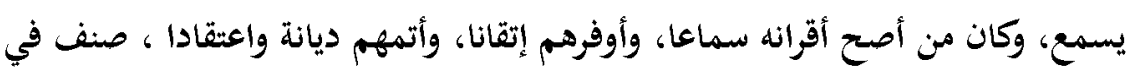

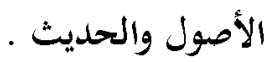

$$
\text { وقال السمعاني : هو ثقة في الحديث. }
$$

وقال الذهبي : كان شيخ خراسان علماً ورئاسة وعلو إسناد. وانتقى له الحاكم أبو عبد فيد

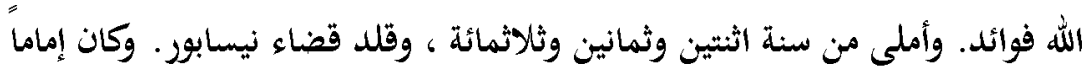
عارفا بمذهب الشافعي. خلاصة حاله أنه : ثقة. 


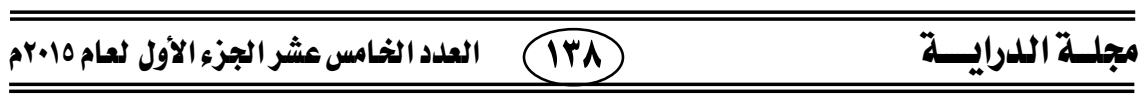

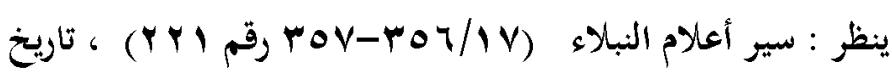

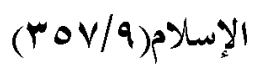

(Y) ( حاجب بن أحمد بن يوحم بن سفيان، أبو محمد، الطوسي، النيسابوري. حلّث عن: محمد بن رافع القشيري، ومحمد بن يحيى الذهلي، وغيرهما .

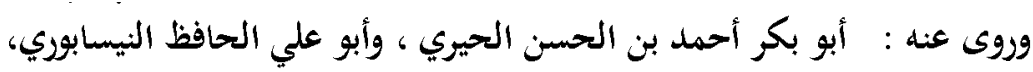
وغيرهما خالاصة حاله أنه : ثقة ولم أجد فيه ما ينزله عن التوثيق .

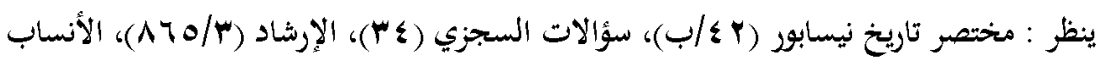

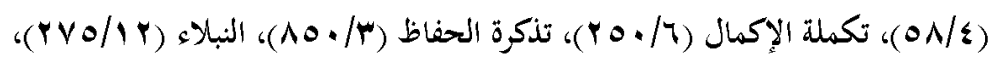

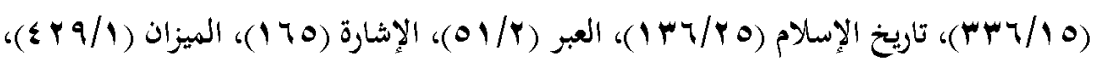

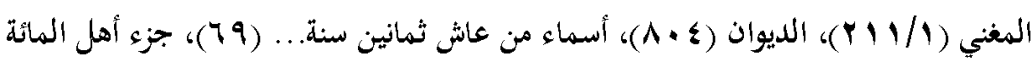

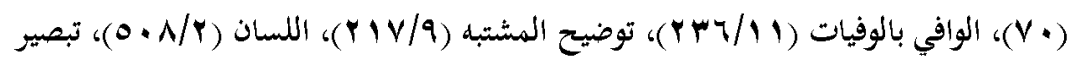

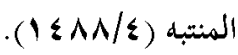

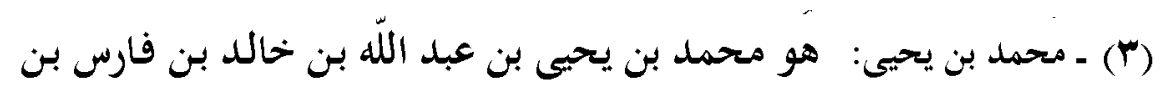

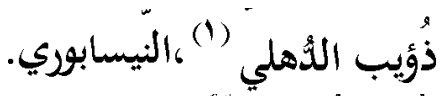
خلالاصة حاله أنه: ثقدة حافئ

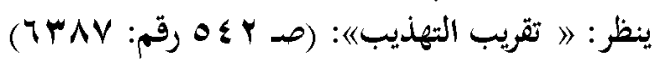

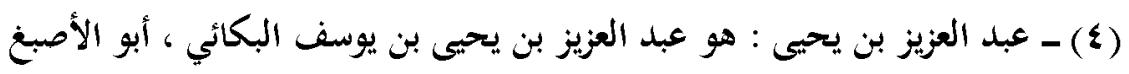
الحراني. خلاصة حاله أنه : مدوقه

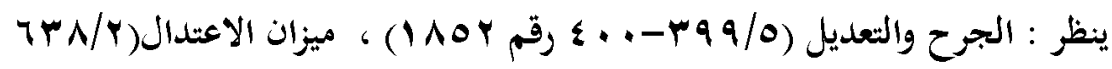

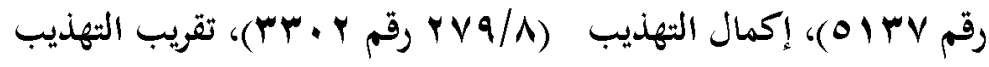

$\cdot(\xi \mid r \cdot)$

( (1)-الذُّهُلّي: بضم الذال المعجمة وسكون الهاء وفي آخرها اللام، هذه النسبة إلى قبيلة معروفة وهو ذهل

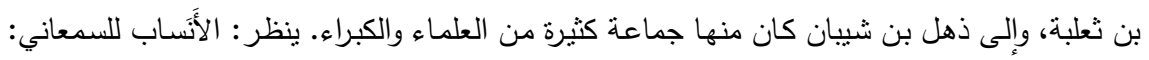




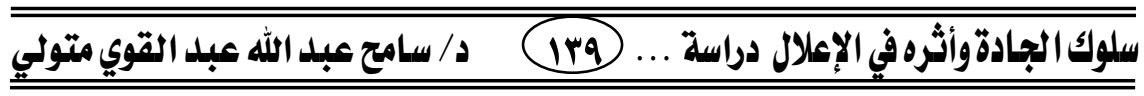

(0) ـ محمد بن سلمة بن عبد الله، الباهلي، مولاهم، أبو عبد الله الحراني.

خلاصة حاله أنه : ثقة.

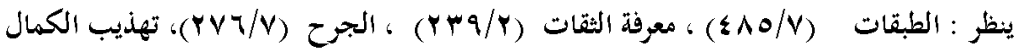

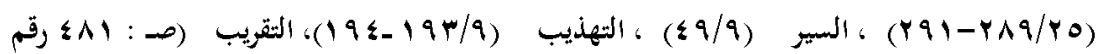

(OGYY

(7) محمد بن إسحاق: هو محمد بن إسحاق بن يسار المدني، أبو بكر، ويقال:

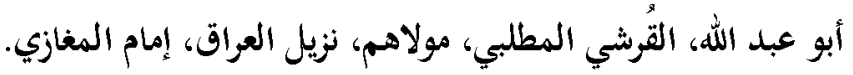

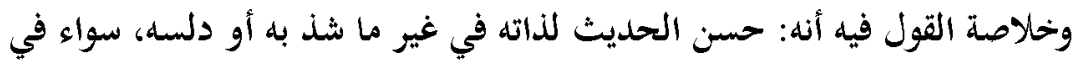
ذلك ما تعلق بالأحكام، أو ما تعلق بالمغازي والسيرة ونحوهما، ولكنه يقدم في التهدي

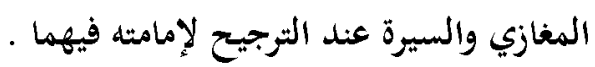

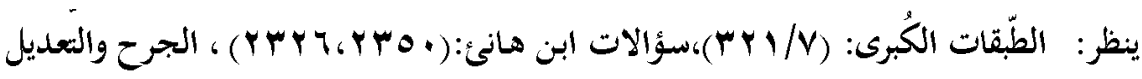

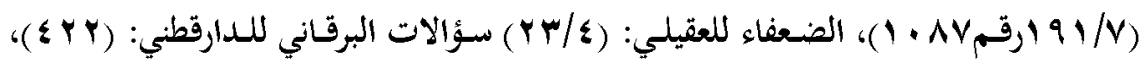

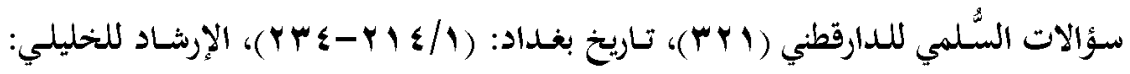

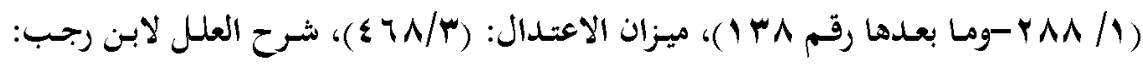

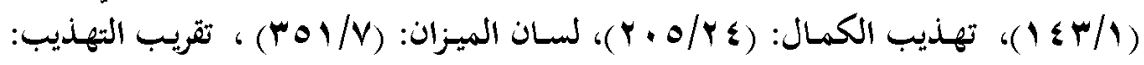

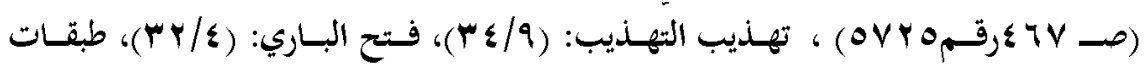

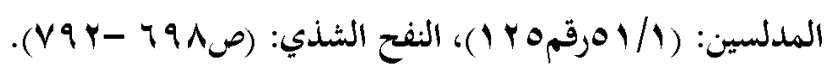

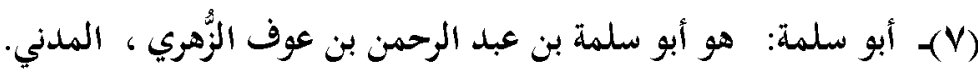
وخلاصة حاله أنه: ثقة مكثر .

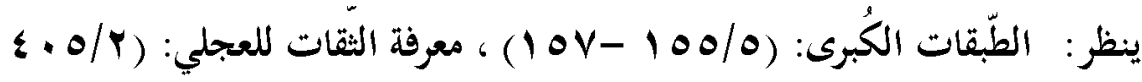

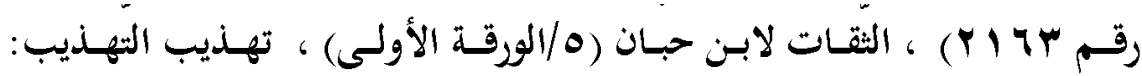

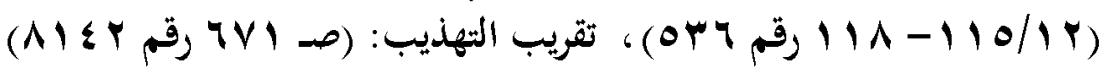

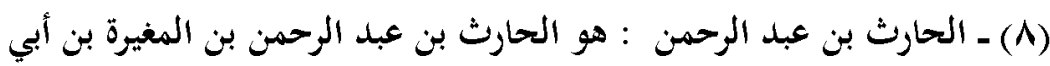

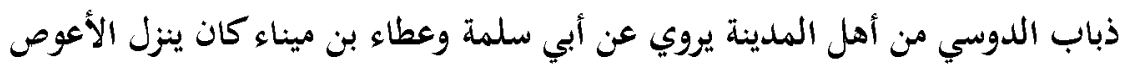

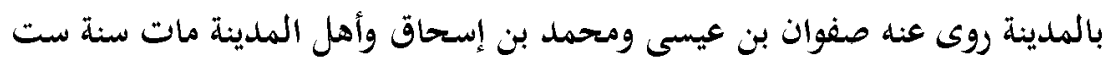
وأربعين ومائة 


\section{مجلـة اللدرايسـة ت}

خلاحة حاله أنه : ثلقة.

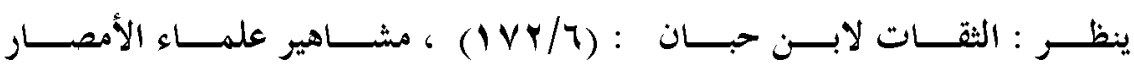

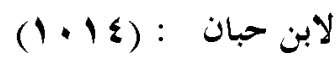

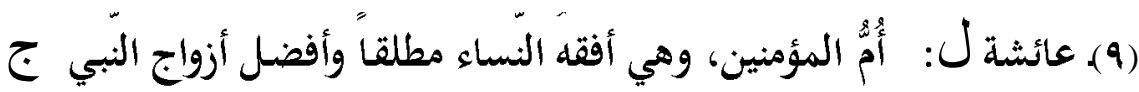

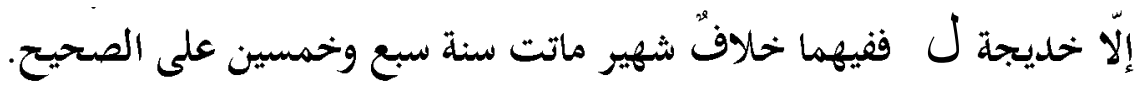

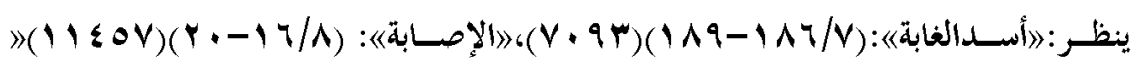

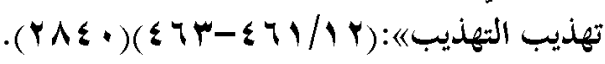

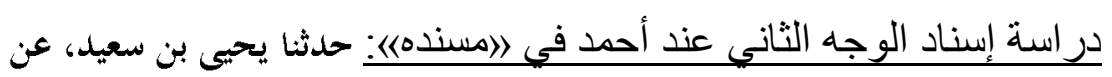
محمد بن عمرو، حد ثنا أبو سلمة، عن أبي هريرة ....

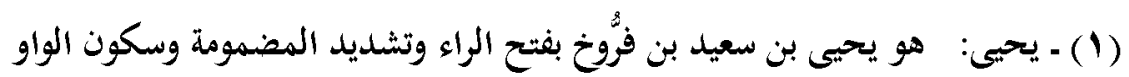
ثم معجمة القطّان الثميمي، أبو سعيد البصري، الأحول، الحافظ. خلاصة حاله أنه: ثقة حافظ متقن.

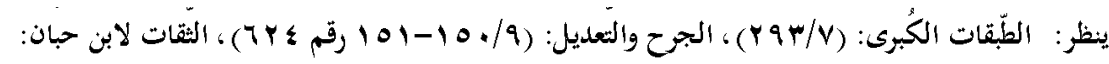

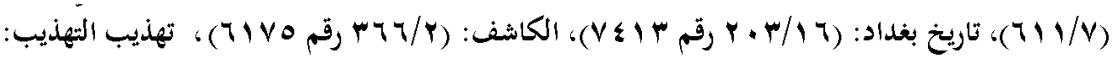

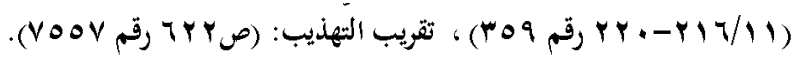

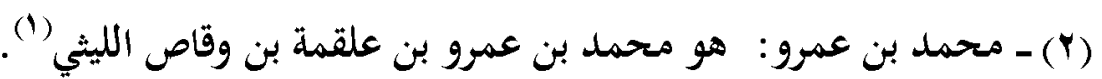
وخلاصة حاله أنه: صدوق له أوهام، وحديثه في مرتبة الحسن.

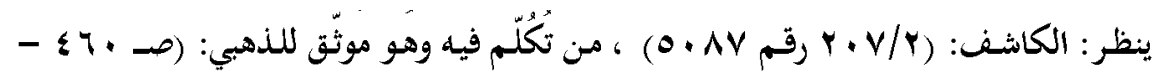

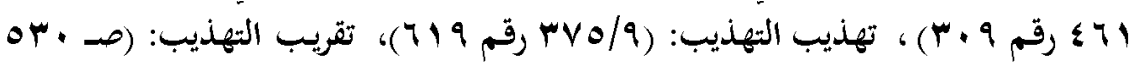

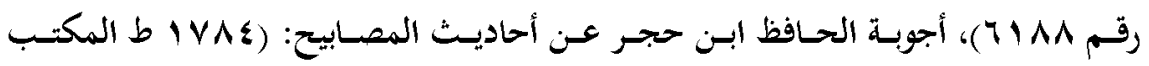
الألباني). (Y) - أبو سلمة: هو أبو سلمة بن عبد الزحمن بن عوف الزُّهري ، المدني.

( (1) اللَّنيّ: بفتح اللام وتتديدها وسكون الياء المنقوطة من تحتها بنقطنين وفي آخرها ثاء منقوطة بثلاث

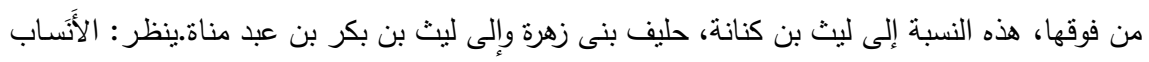

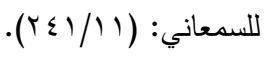




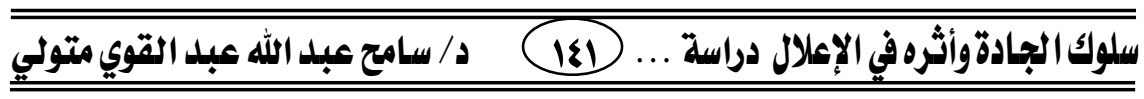

وخلاصة حاله أنه: ثقة مكثر. تقدمت ترجمته في الوجه الأول .

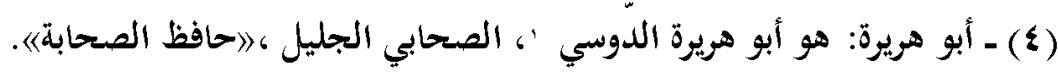

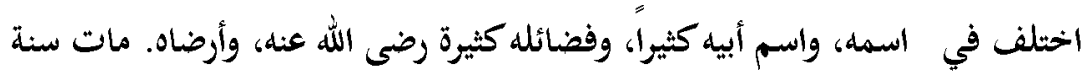

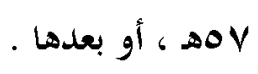

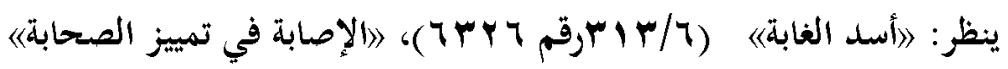
. ( $9 \leq 1 / \mathrm{r})$

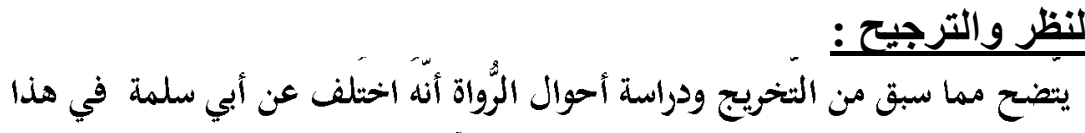

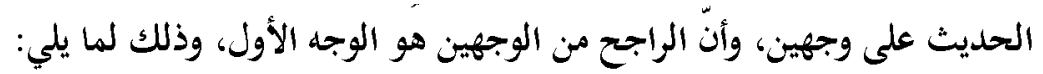

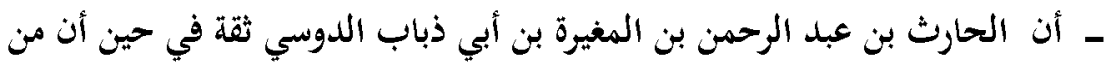

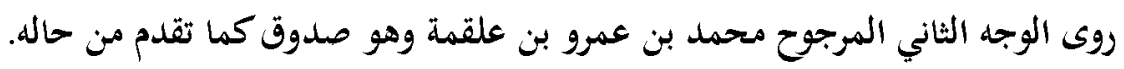

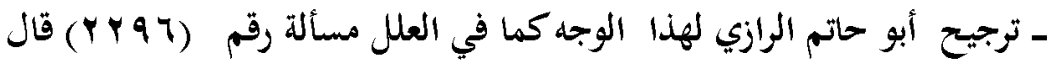

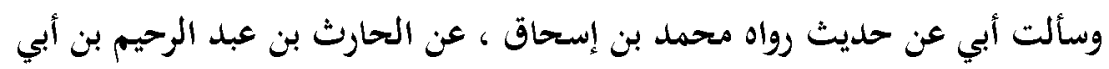
ذباب، عن أبي سلمة ، عن عائشة، عن النبي ج أكمل المؤمنين إيمانًا أحسنهم خلقًا.

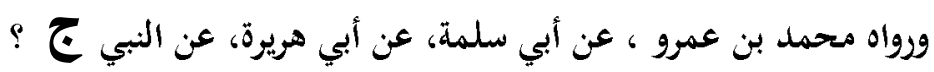

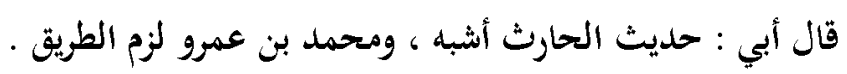

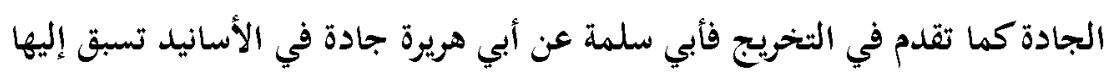

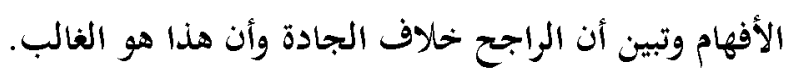
الحكم على الحديث : الحيث:

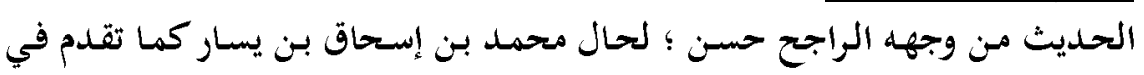

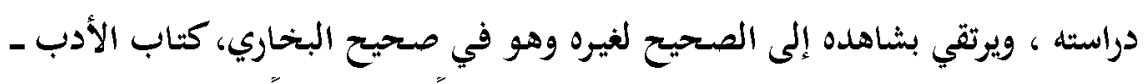

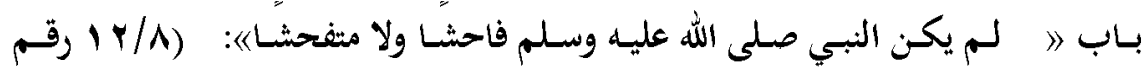

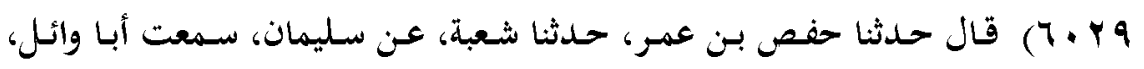

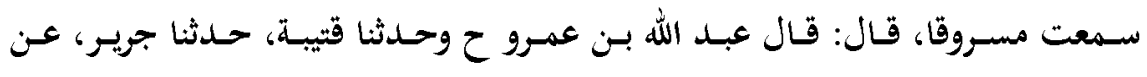

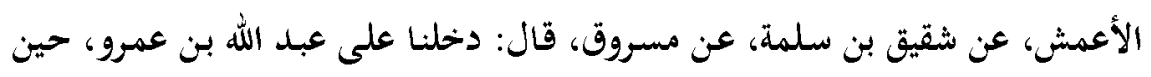




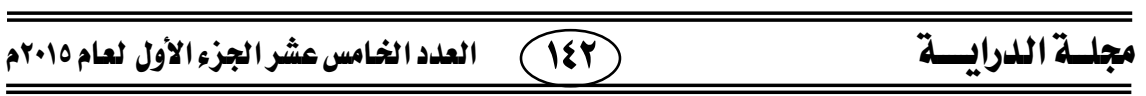

قدم مع معاوية إلى الكوفة، فذكر وسول الله صلى الله عليه وسلم فقال: لم يكن فاحشّا ولا متفحشّا، وقال: قال رسول الله صـلى الله عليه وسـلم: إإن مـن أخيركم أحســكم خلقا《

\section{النظر في قرينة الاعلال وهى م (سلوك الجادة ) :}

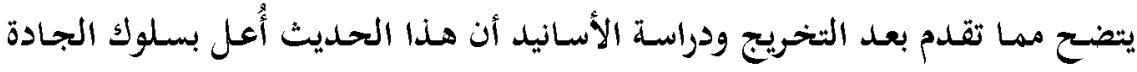
(فأبي سلمة ، عن أبي هريرة عن النبي ج ) جادة تسبق إليها الألسنة وهي معروفة ومثهورة ، بخحلاف غير الجادة ( عن أبي سلمة عن أم المؤمنين عائشة عن النبي ج ج )، وقد أعل النقاد وعلى رأسهم أبو حاتم الرازي الحديث بهذه القريثة. 


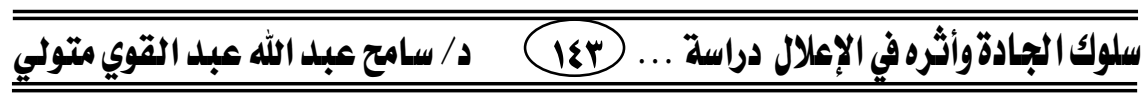 \\ الخاتثة}

بعد هذه الرحلة في الكتاب العظيم أعني علل ابن أبي حاتم ، ومعالجة مسائل هذا

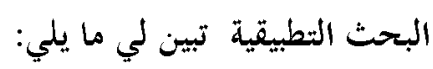

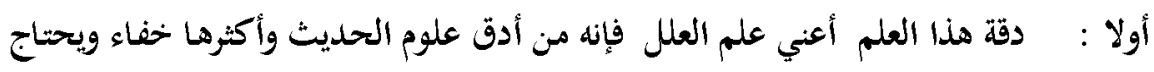

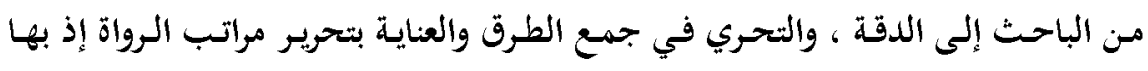

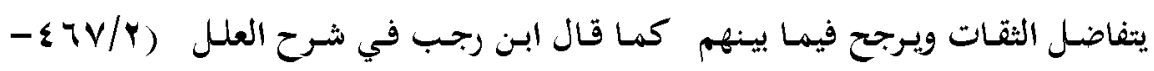

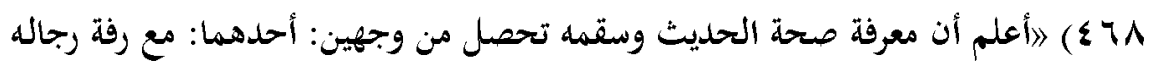

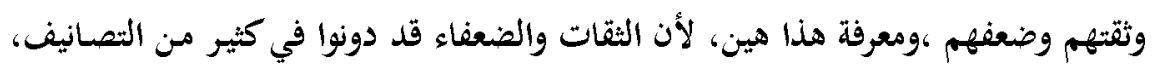

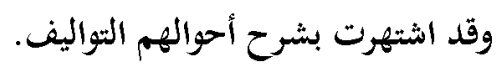

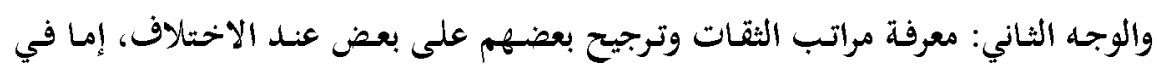

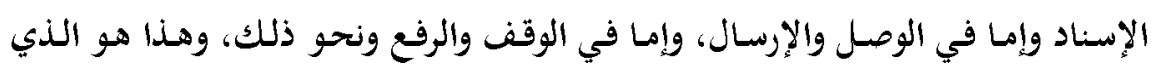

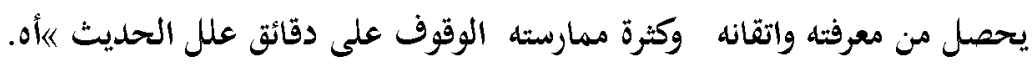

ثانيا : إمامة أبو حاتم الرازي، وأبو زرعة الرازي، وابن أبي حاتم في هذا العلم وحسبك

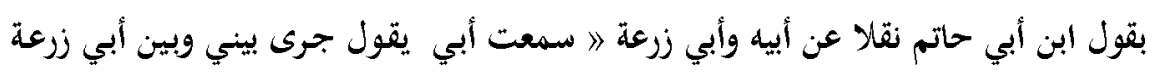

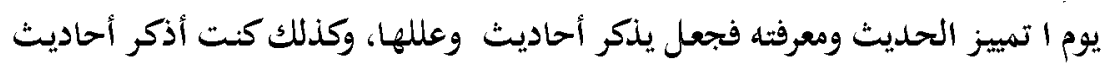

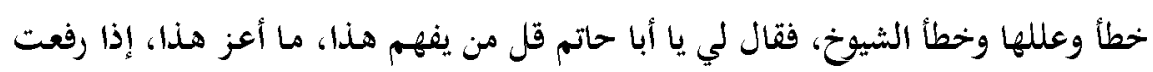

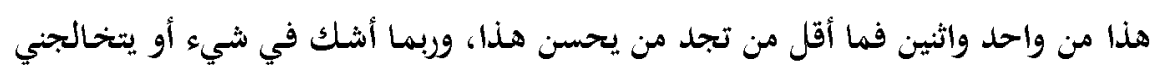

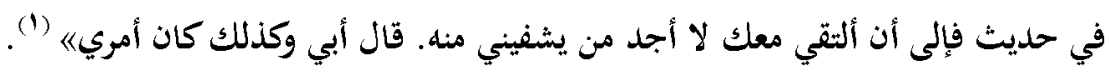

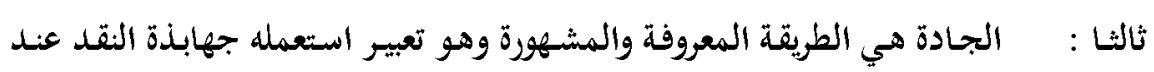

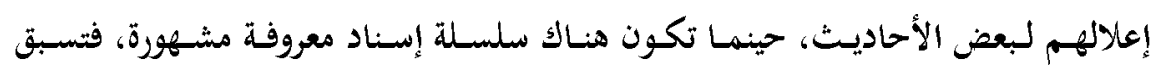

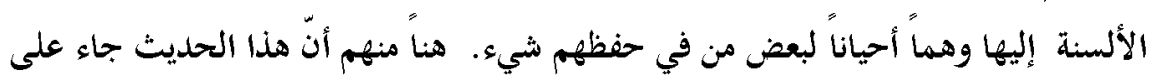

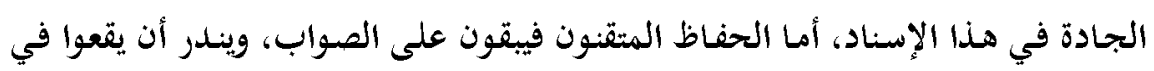




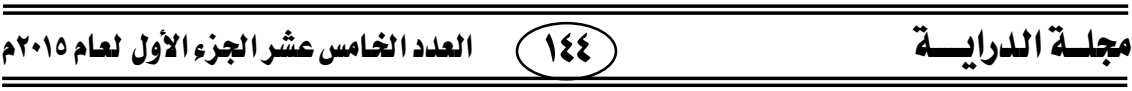

مثل ذلك ، ويقول الأئمة النقاد إن الأول سلك الجادة ، وأخذ طريقًا معروفًا تسبق إليه

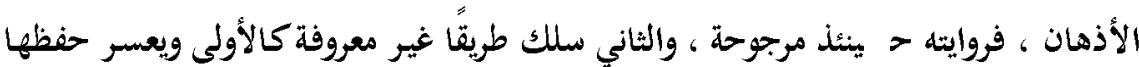

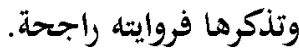

رابعا : في الغالب يأتي الوهم في سلوك طريق الجادة وعدم التنبها إلى الطريق الأخرى

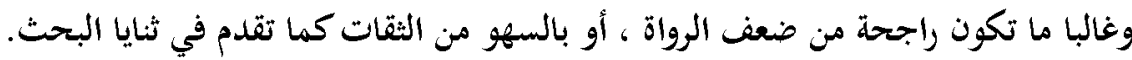

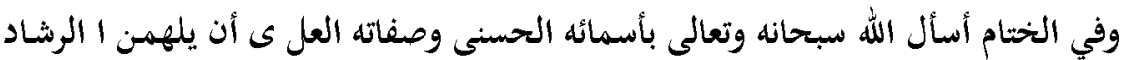
والصواب ، كما أسأله سبحانه وتعالى أن يبارك في هذا البحث، ويجعله نافعا لنا ولطلبة العلم ، وكذلك كل الجهود التي تبـل لخدمة السنة النبوية المباركة، كمـا أسأله سبحانه

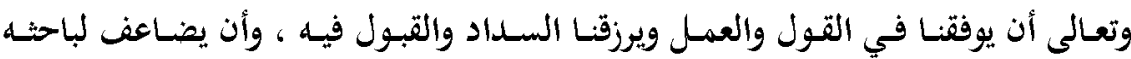

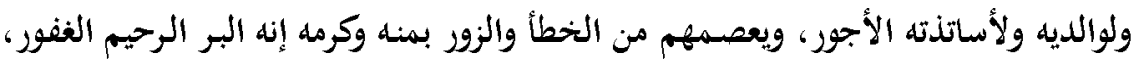
ويدخلهم في جناته النعيم بدون حساب ولا كتاب بفضله ورحمته، فإنه على ذلك قدير، ربنا لا تؤاخذنا إن نسينا أو أخطأنا....

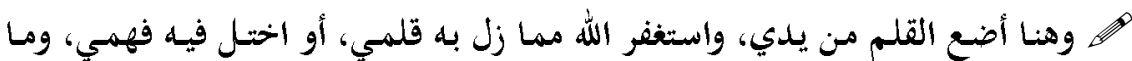

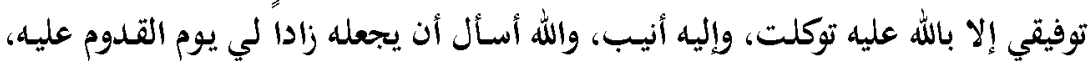

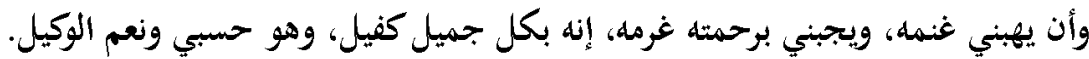
وصلى الله تعالى على خير خلقه محمد، وعلى آله وصحبه أجمعين، أمين.

\section{د. ـ سامح عبدالله عبد القوي}

\section{ملدرس الحليث وعلومه بكلية أصول اللين بالقاهرة}




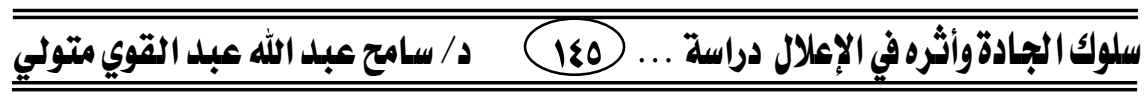 \\ فهرس بـأهم مصادرومراجع البحث}

| 1

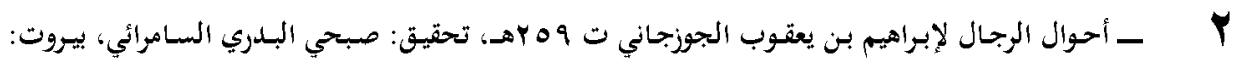

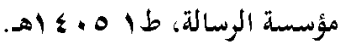

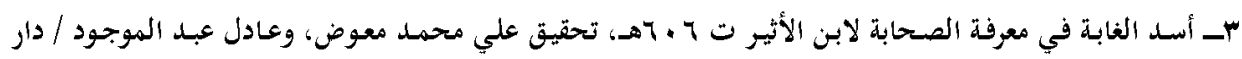

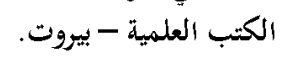

ع-إتحاف المهرة بالفوائد المبتكرة من أطراف العشرة لابن حجر ت ب مهـ، تحقيق مركز خدمة السنة والسيرة النبوية

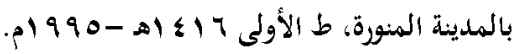

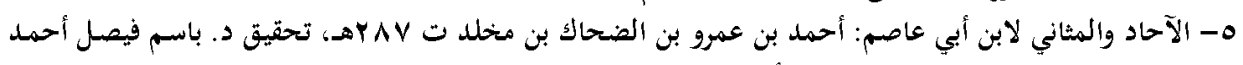

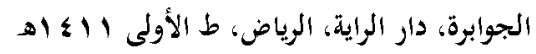

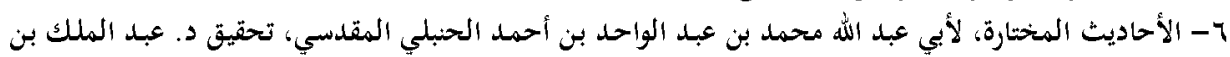

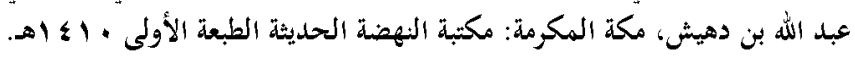

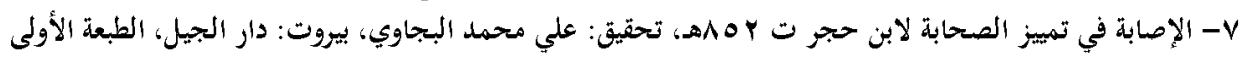

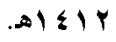

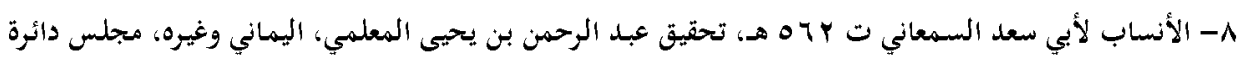

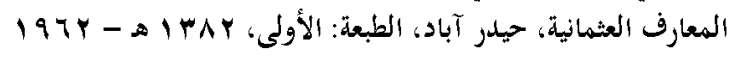

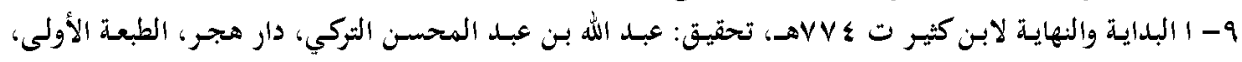

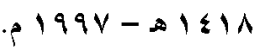

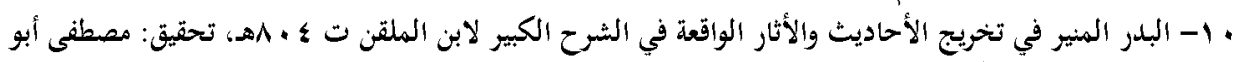

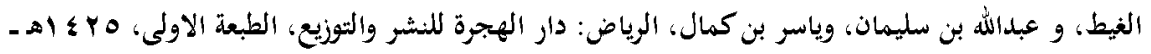

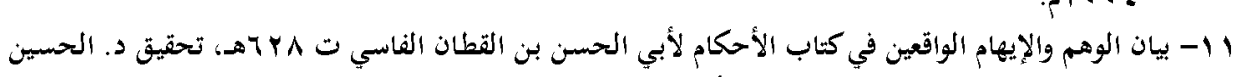

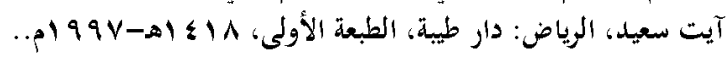

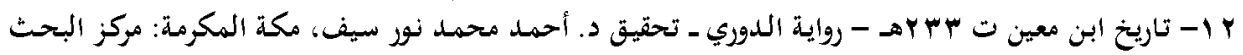

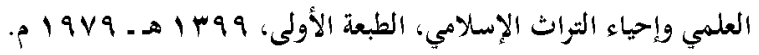

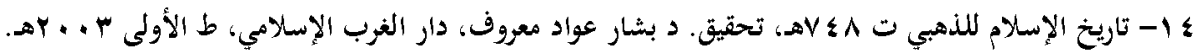

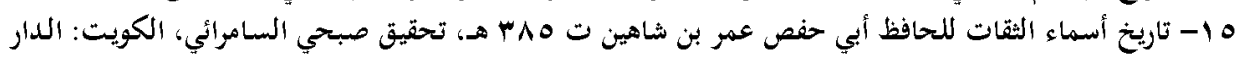

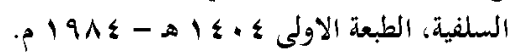

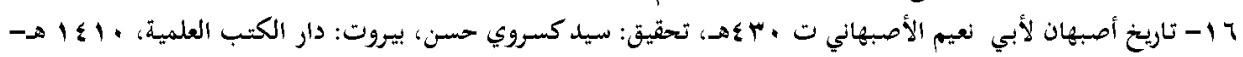
تاريخ

V V ا ثاريخ جرجان لحمزة بن يوسف أبو القاسم الجرجاني، تحقيق د. محمل عبد المعيد خحان، بيروت: عالم الكتب، الطبعة الثالثة،

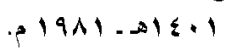

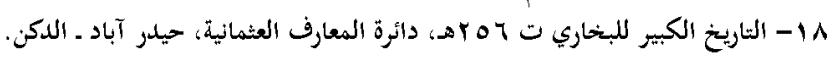

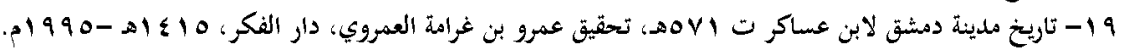

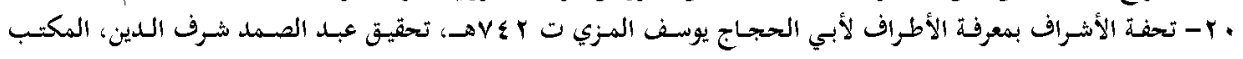

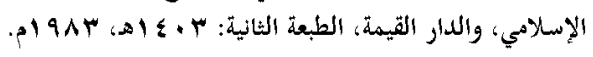




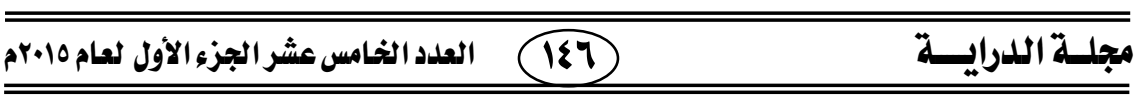

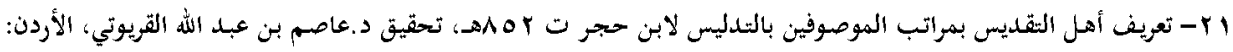

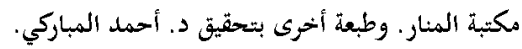

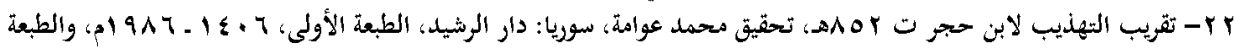

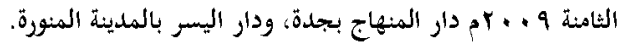

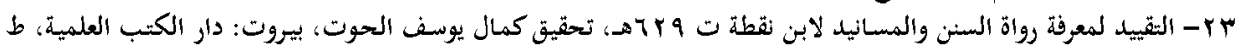

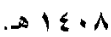

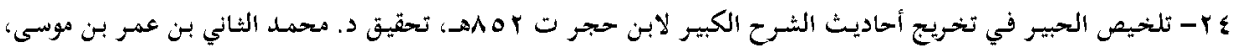

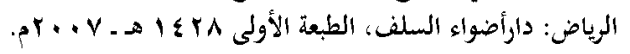

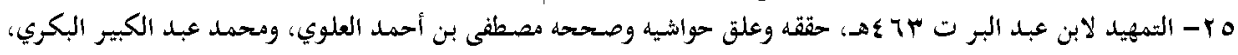

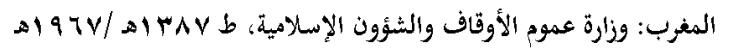

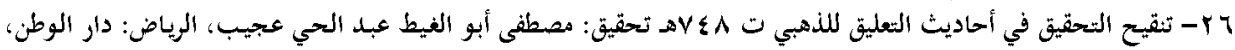

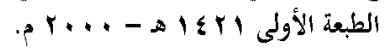

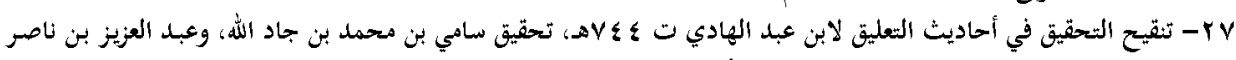

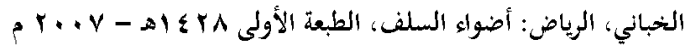

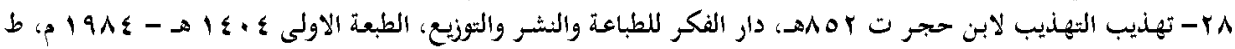

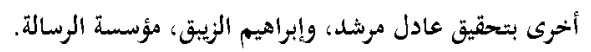

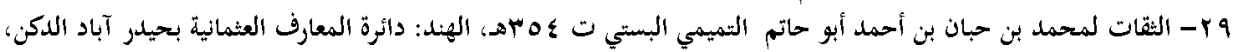

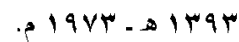

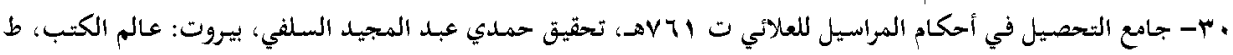

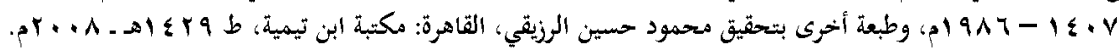

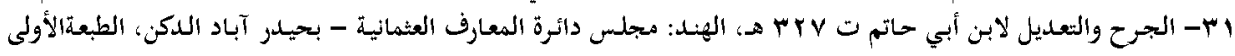
الجر

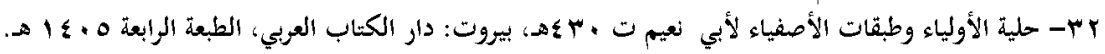

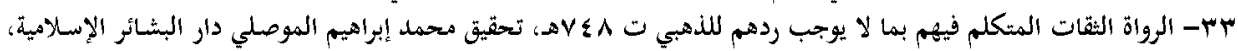

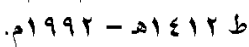

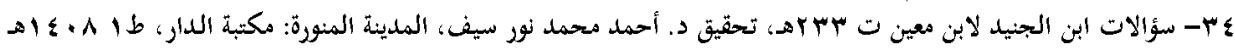

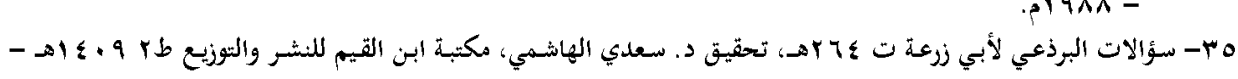

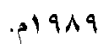

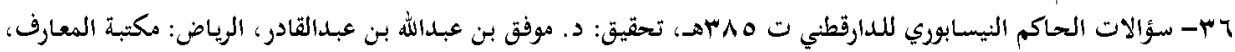

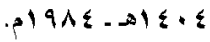

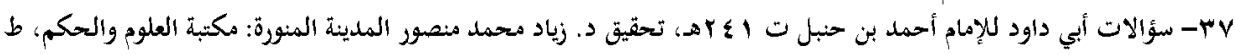
أهو

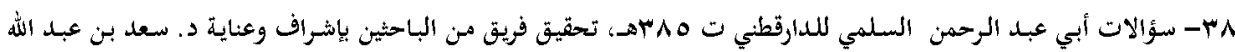

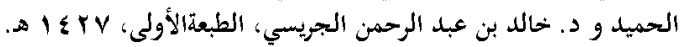

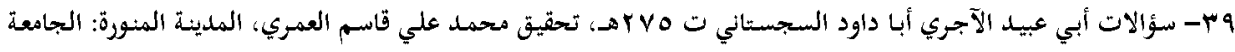

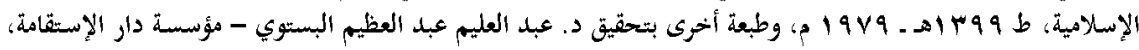

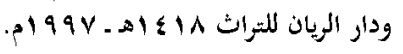

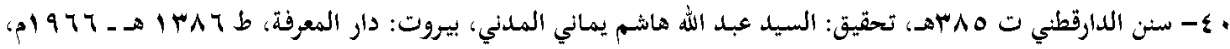

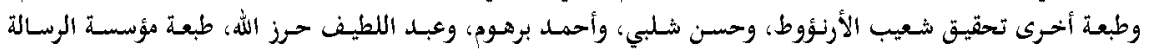




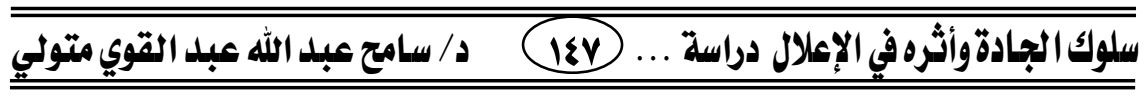

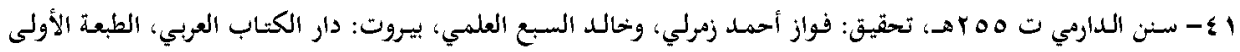

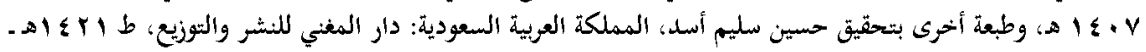

.

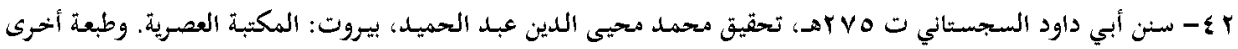

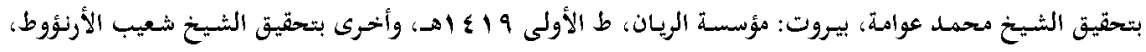

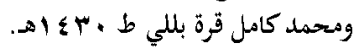

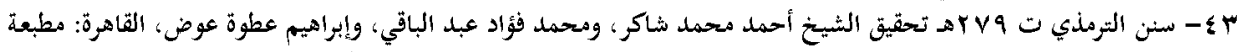

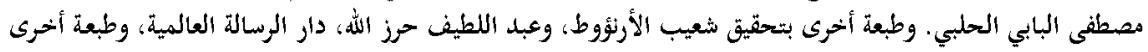

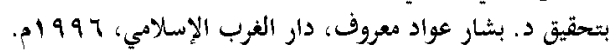

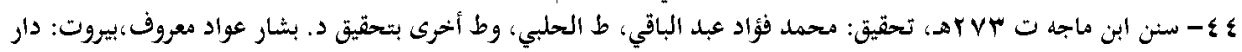

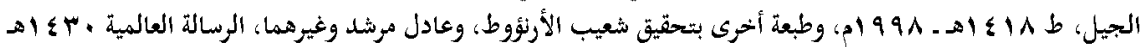

.

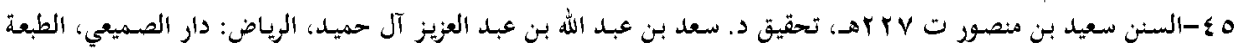

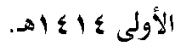

7 ـ ـ سنن النسائي ت ب + آهـ ( المجتبى)، عناية الشيخ عبد الفتاح أبو غدة، حلب: مكتب المطبوعات الإسلامية، الطبعة الثانية،

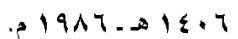

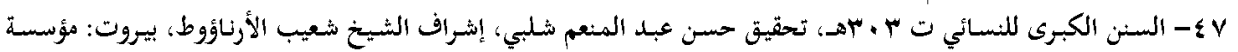

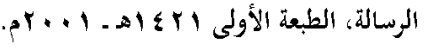

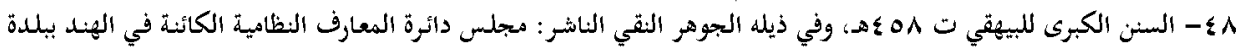

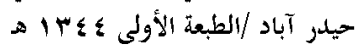

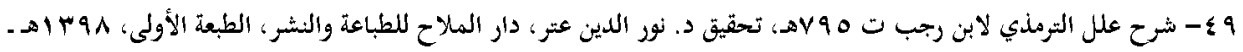

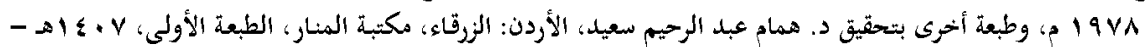

. 19 ANY

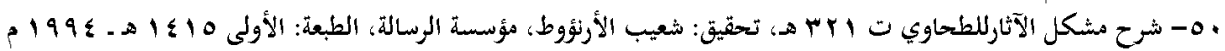

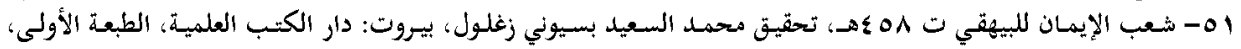

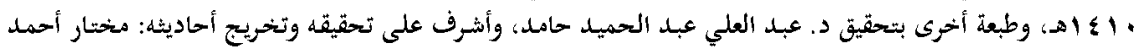

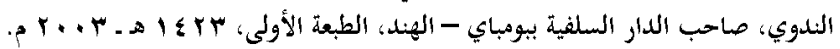

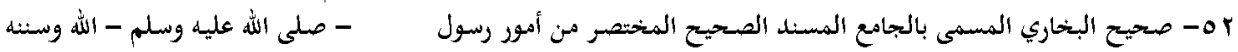

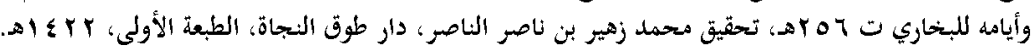

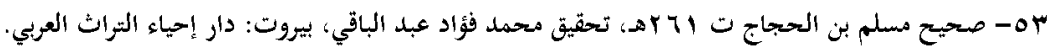

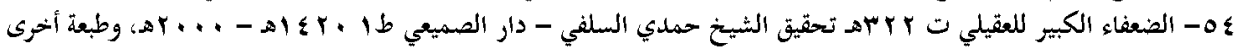

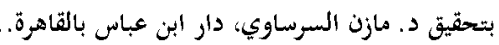

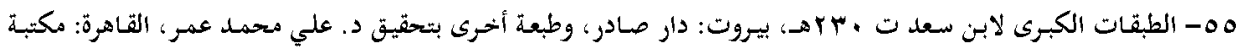

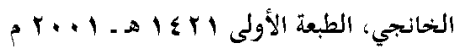

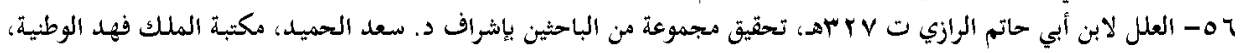

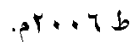

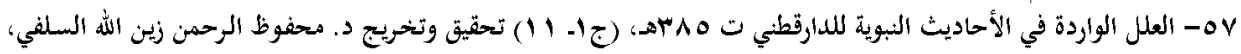

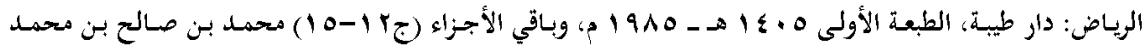

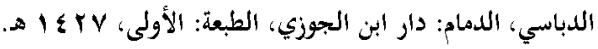

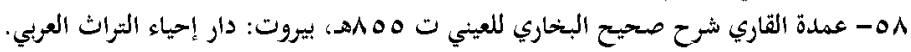

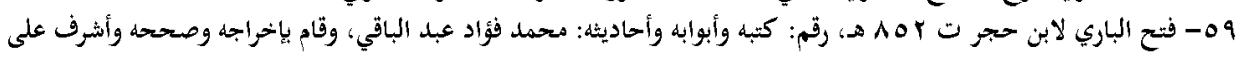




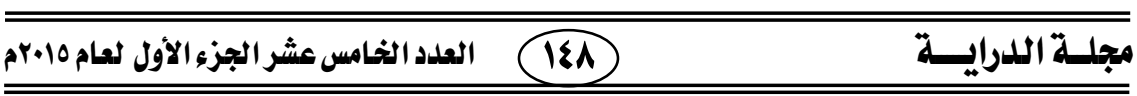

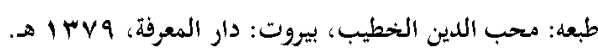

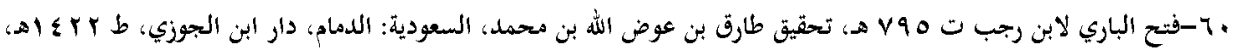

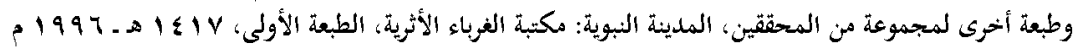

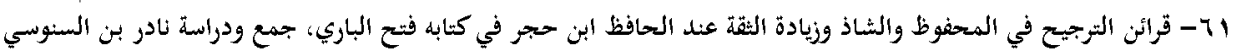

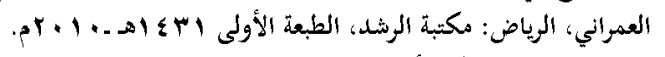

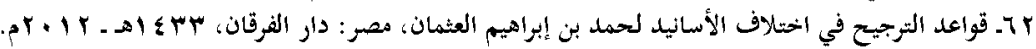

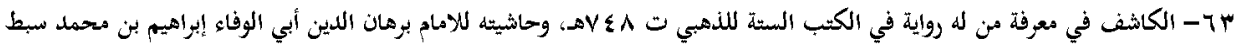

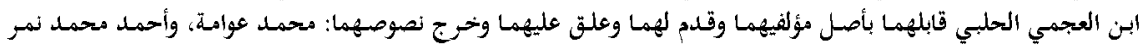

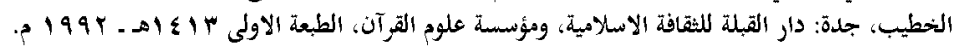

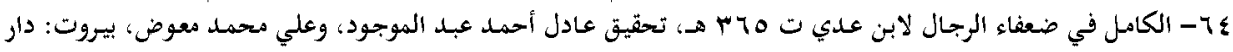

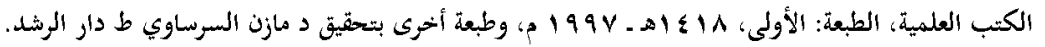

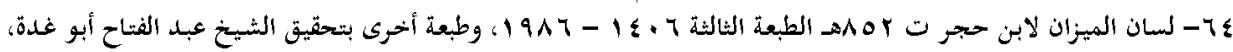

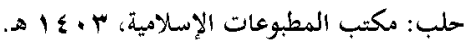

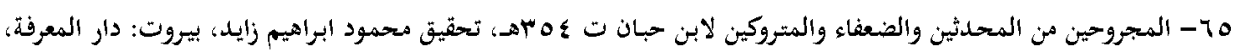

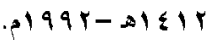

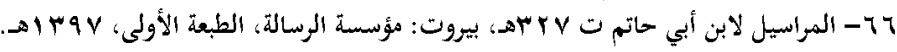

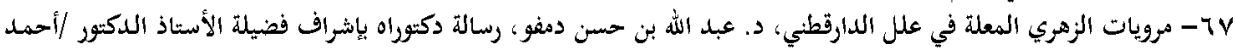

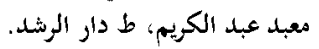

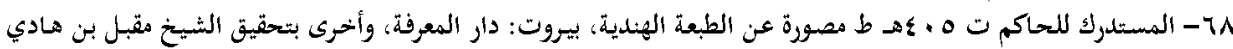

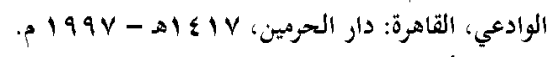

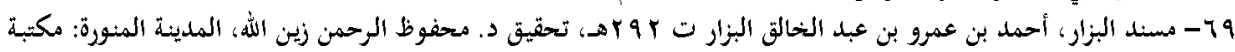

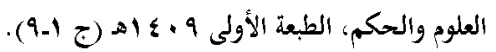

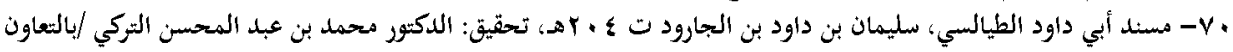

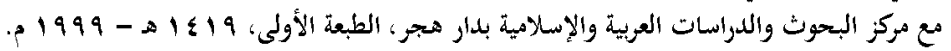

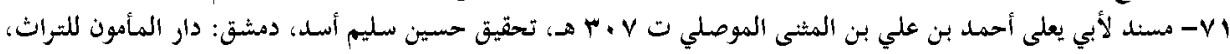

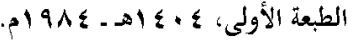

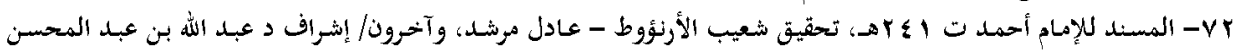

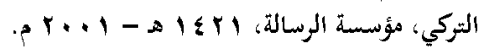

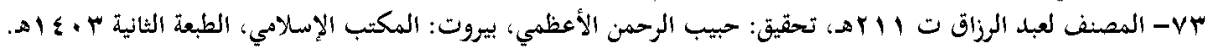

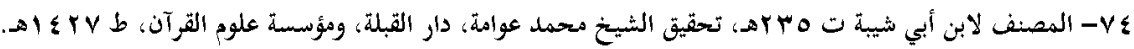

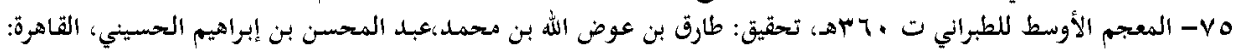

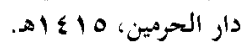

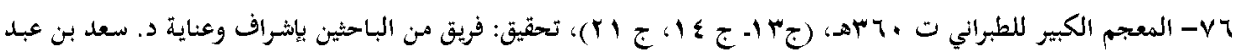

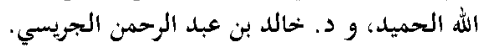

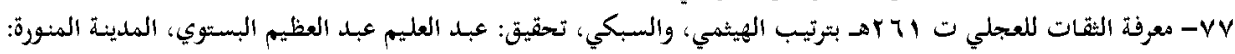

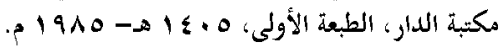

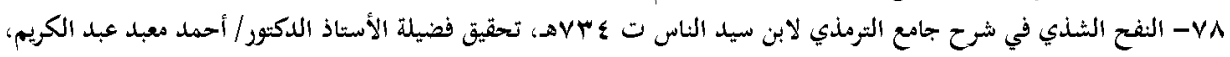
الرياض: دار العاصمة، الطبعة الأولى 9 + ــ أهـ 